\title{
Radioactive Demonstration of Final Mineralized Waste Forms for Hanford Waste Treatment Plant Secondary Waste (WTP-SW) by Fluidized Bed Steam Reforming (FBSR) using the Bench Scale Reformer Platform
}

\author{
C.L. Crawford \\ P.R. Burket \\ A.D. Cozzi \\ W.E. Daniel \\ C.M. Jantzen \\ D.M. Missimer
}

December 2011

Savannah River National Laboratory

Savannah River Nuclear Solutions, LLC Aiken, SC 29808

Prepared for the U.S. Department of Energy under contract number DE-AC09-08SR22470. 
SRNL-STI-2011-00331

Revision 0

\section{DISCLAIMER}

This work was prepared under an agreement with and funded by the U.S. Government. Neither the U.S. Government or its employees, nor any of its contractors, subcontractors or their employees, makes any express or implied:

1. warranty or assumes any legal liability for the accuracy, completeness, or for the use or results of such use of any information, product, or process disclosed; or

2. representation that such use or results of such use would not infringe privately owned rights; or

3. endorsement or recommendation of any specifically identified commercial product, process, or service.

Any views and opinions of authors expressed in this work do not necessarily state or reflect those of the United States Government, or its contractors, or subcontractors.

\section{Printed in the United States of America \\ Prepared for \\ U.S. Department of Energy}


Keywords: Hanford wastes, melter condensate, waste form, disposal

Retention: Permanent

\title{
Radioactive Demonstration of Final Mineralized Waste Forms for Hanford Waste Treatment Plant Secondary Waste (WTP-SW) by Fluidized Bed Steam Reforming (FBSR) using the Bench Scale Reformer Platform
}

\author{
C.L. Crawford \\ P.R. Burket \\ A.D. Cozzi \\ W.E. Daniel \\ C.M. Jantzen \\ D.M. Missimer
}

December 2011

Savannah River National Laboratory Savannah River Nuclear Solutions, LLC Aiken, SC 29808

Prepared for the U.S. Department of Energy under

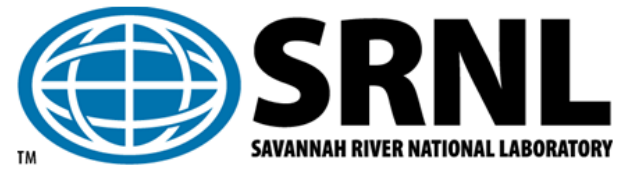
contract number DE-AC09-08SR22470. 
AUTHORS:

\section{REVIEWS AND APPROVALS}

C. L. Crawford, Process Technology Programs Date

P.R. Burket, Engineering Process Development $\quad$ Date

A.D. Cozzi, Engineering Process Development Date

W.E. Daniel, Engineering Process Development $\quad$ Date

\begin{tabular}{ll}
\hline C.M. Jantzen, Process Technology Programs & Date
\end{tabular}

\begin{tabular}{lc}
\hline D.M. Missimer, Analytical Development & Date
\end{tabular}

TECHNICAL REVIEW:

D. K. Peeler, Process Technology Programs $\quad$ Date

J. M. Pareizs, Process Technology Programs $\quad$ Date

Arlin Olson, ART Project Technical Lead Date

THOR Treatment Technologies, LLC

APPROVAL:

C. C. Herman, Manager $\quad$ Date

Process Technology Programs

S.L. Marra, Manager

Date

Environmental \& Chemical Process Technology Research Programs

Brent Evans, ART Project Manager

Date

THOR Treatment Technologies, LLC 
SRNL-STI-2011-00331

Revision 0

\section{ACKNOWLEDGEMENTS}

The testing of the non-radioactive pilot scale Fluidized Bed Steam Reformer (FBSR) products, monolith testing and studies, and Waste Treatment Plan - Secondary Waste (WTP-SW) radioactive campaign were funded by the DOE Advanced Remediation Technologies (ART) Phase 2 Project in connection with a Work-For-Others (WFO-09-003, Mod. 3, 09/21/11) with THOR Treatment Technologies, LLC (TTT) that ends on $12 / 31 / 11$.

The authors would like to thank TTT for their technical guidance and support during the execution of this work scope.

The authors would like to thank Babb Attaway who is manager of the SRNL Shielded Cell Operations (SCO) group and the SCO technical team consisting of Carolyn Conley, Steve Beard, Lucy Beasley, Ron Blessing, Phyllis Burkhalter, Jane Howard, Monica Jenkins, Jeffery Mixon, Raenan Stanley, Rita Sullivan, and Denise Wheeler. SRNL researchers would also like to thank Frances Williams, Don Miller, Vern Bush, Michael Lee, Vickie Williams, Pat Simmons, Sherry Vissage, Ronnie Rutherford, David Best, Whitney Riley, Beverly Wall, and Kimberly Wyszynski.

The authors would also like to thank SRNL Analytical Development for $\mathrm{Fe}^{2+} / \Sigma \mathrm{Fe}$ measurements and digestions for chemical/radiochemical composition and mass balance activities supported by Damon Click, Chuck Coleman, Dave DiPrete, Ceci DiPrete, Boyd Wiedenman, Mark Jones, Curtis Johnson, Tom White, and Rob Lascola. SRNL would also like to thank personnel from the Separations Science Program: John Scogin and Wanda Mathews for the radioactive BET measurements and Michael Bronikowski and Michael Lee for the radioactive density measurements.

The authors would also like to thank Holly Hall and all the regulatory support personnel including Kerri Crawford, and Amy Blunt for all the guidance that has helped SRNL perform these treatability studies in compliance with Resource Conservation \& Recovery Act (RCRA) waste handling.

SRNL is operated and managed by Savannah River Nuclear Solutions, LLC, acting under Contract No. DE-AC09-08SR22470 with the U.S. Department of Energy (DOE). 
SRNL-STI-2011-00331

Revision 0

BLANK PAGE

Page 6 of 177 
SRNL-STI-2011-00331

Revision 0

\section{EXECUTIVE SUMMARY}

The U.S. Department of Energy's Office of River Protection (ORP) is responsible for the retrieval, treatment, immobilization, and disposal of Hanford's tank waste. Currently there are approximately 56 million gallons of highly radioactive mixed wastes awaiting treatment. A key aspect of the River Protection Project (RPP) cleanup mission is to construct and operate the Waste Treatment and Immobilization Plant (WTP). The WTP will separate the tank waste into high-level and low-activity waste (LAW) fractions, both of which will subsequently be vitrified.

The projected throughput capacity of the WTP LAW Vitrification Facility is insufficient to complete the RPP mission in the time frame required by the Hanford Federal Facility Agreement and Consent Order, also known as the Tri-Party Agreement (TPA), i.e. December 31, 2047. Therefore, Supplemental Treatment is required both to meet the TPA treatment requirements as well as to more cost effectively complete the tank waste treatment mission. In addition, the WTP LAW vitrification facility off-gas condensate known as WTP Secondary Waste (WTP-SW) will be generated and enriched in volatile components such as ${ }^{137} \mathrm{Cs},{ }^{129} \mathrm{I},{ }^{99} \mathrm{Tc}, \mathrm{Cl}, \mathrm{F}$, and $\mathrm{SO}_{4}$ that volatilize at the vitrification temperature of $1150^{\circ} \mathrm{C}$ in the absence of a continuous cold cap (that could minimize volatilization). The current waste disposal path for the WTP-SW is to process it through the Effluent Treatment Facility (ETF). Fluidized Bed Steam Reforming (FBSR) is being considered for immobilization of the ETF concentrate that would be generated by processing the WTP-SW. The focus of this current report is the WTP-SW.

FBSR offers a moderate temperature $\left(700-750^{\circ} \mathrm{C}\right)$ continuous method by which WTP-SW wastes can be processed irrespective of whether they contain organics, nitrates, sulfates/sulfides, chlorides, fluorides, volatile radionuclides or other aqueous components. The FBSR technology can process these wastes into a crystalline ceramic (mineral) waste form. The mineral waste form that is produced by co-processing waste with kaolin clay in an FBSR process has been shown to be as durable as LAW glass. Monolithing of the granular FBSR product is being investigated to prevent dispersion during transport or burial/storage, but is not necessary for performance.

A Benchscale Steam Reformer (BSR) was designed and constructed at the SRNL to treat actual radioactive wastes to confirm the findings of the non-radioactive FBSR pilot scale tests and to qualify the waste form for applications at Hanford. BSR testing with WTP SW waste surrogates and associated analytical analyses and tests of granular products (GP) and monoliths began in the Fall of 2009, and then was continued from the Fall of 2010 through the Spring of 2011.

Radioactive testing commenced in 2010 with a demonstration of Hanford's WTP-SW where Savannah River Site (SRS) High Level Waste (HLW) secondary waste from the Defense Waste Processing Facility (DWPF) was shimmed with a mixture of ${ }^{125 / 129} \mathrm{I}$ and ${ }^{99} \mathrm{Tc}$ to chemically resemble WTP-SW. Prior to these radioactive feed tests, non-radioactive simulants were also processed. Ninety six grams of radioactive granular product were made for testing and comparison to the non-radioactive pilot scale tests. The same mineral phases were found in the radioactive and non-radioactive testing.

The granular products (both simulant and radioactive) were tested and a subset of the granular material (both simulant and radioactive) were stabilized in a geopolymer matrix. Extensive testing and characterization of the granular and monolith material were made including the following:

- $\quad$ ASTM C1285 (Product Consistency Test) testing of granular and monolith

- $\quad$ ASTM C1308 accelerated leach testing of the radioactive monolith

- $\quad$ ASTM C192 compression testing of monoliths

- $\quad$ EPA Method 1311 Toxicity Characteristic Leaching Procedure (TCLP) testing 
SRNL-STI-2011-00331

Revision 0

The significant findings of the testing completed on simulant and radioactive WTP-SW are given below:

- Data indicates ${ }^{99} \mathrm{Tc}, \mathrm{Re}, \mathrm{Cs}$, and I (all isotopes) report primarily to the mineral product and not significantly to the off-gas

- $\quad{ }^{99} \mathrm{Tc}$ and Re show similar behavior in partitioning between product (major) and off-gas (trace) so Re is an acceptable surrogate for ${ }^{99} \mathrm{Tc}$

- ${ }^{99} \mathrm{Tc}, \mathrm{Re}, \mathrm{SO}_{4}$ and $\mathrm{Cr}$ behavior, with respect to their durability in the final granular product, are controlled by the oxygen fugacity in the FBSR/BSR process, i.e. control of the REDuction/OXidation (REDOX) equilibrium

- Mineralogy features related to the XRD patterns associated with the identified crystalline species and their relative amounts in radioactive and simulant products from the BSR and Engineering Scale Technology Demonstration (ESTD) are the same

- TCLP data are acceptable when RCRA metals are not shimmed in excess of their predicted concentrations in actual WTP-SW feeds and REDOX is controlled or an iron oxide catalyst is present as an insoluble spinel host for $\mathrm{Cr}$

- ASTM C1285 (Product Consistency Test) testing is below $2 \mathrm{~g} / \mathrm{m}^{2}$ for the constituents of concern (COC)

o Use of BET surface area to account for the surface roughness of the mineral granules demonstrates that the FBSR product is 2 orders of magnitude lower than the $2 \mathrm{~g} / \mathrm{m}^{2}$ target

- All monoliths made from radioactive and non-radioactive (BSR and the ESTD engineeringscale) granular products pass compression testing at $>500 \mathrm{psi}$, maintain PCT leach rates $<2 \mathrm{~g} / \mathrm{m}^{2}$, and perform well in ASTM C1308 testing such that the measured Leach Indexes for key components $\left(\mathrm{Na}, \mathrm{Re} /{ }^{99} \mathrm{Tc}\right.$ and I) are all below current Hanford Integrated Disposal Facility (IDF) target limits.

- Good mass balance closure on Tc, Re, Cs, and I in all BSR tests (radioactive and non-radioactive) o SRS DWPF Secondary Waste shimmed to match WTP-SW

- $86-102 \%$ recovery of Re in the product streams for simulant and radioactive campaigns

- $109 \%$ recovery of ${ }^{99} \mathrm{Tc}$ in the product streams for radioactive campaign

- $91 \%$ recovery of I in the product streams for the simulant campaign

- $\quad 98 \%$ recovery of ${ }^{129} \mathrm{I}, \sim 93 \%$ recovery of ${ }^{125} \mathrm{I}$, and $151 \%$ recovery of ${ }^{127} \mathrm{I}$ in the product streams $\left({ }^{125} \mathrm{I}\right.$ has highest analytic sensitivity) for radioactive campaign 


\section{TABLE OF CONTENTS}

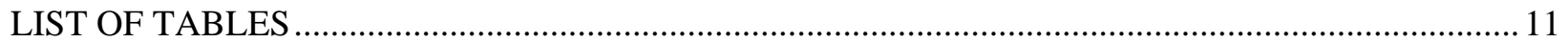

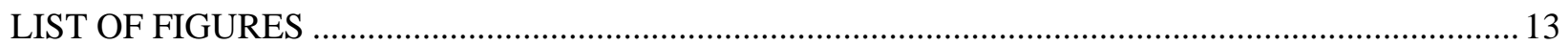

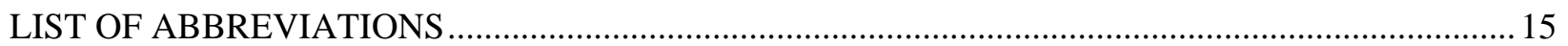

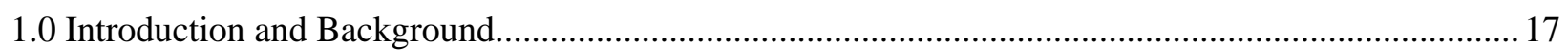

1.1 Pilot and Engineering Scale Testing of Hanford Non-Radioactive LAW and WTP-SW ................. 18

1.2 Mineral Waste Forms: “Historical Perspective Vs Commercialization” ........................................21

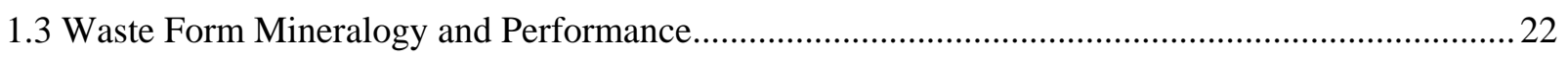

2.0 Objectives and Quality Assurance for WTP SW Bench Scale Reformer Testing ...............................25

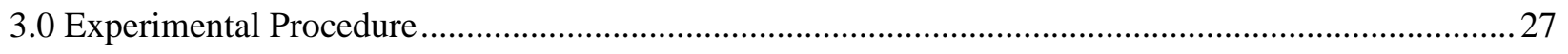

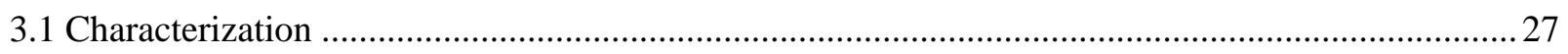

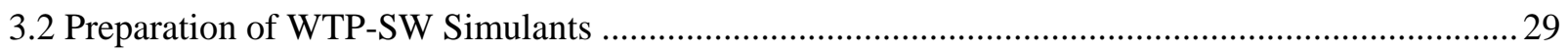

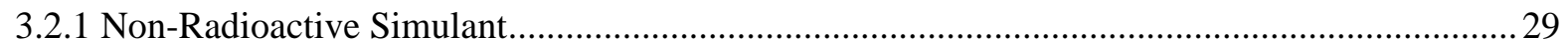

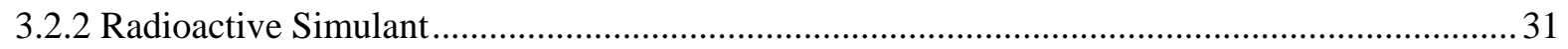

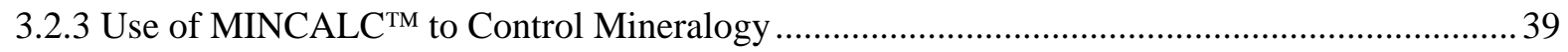

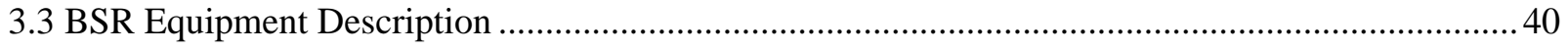

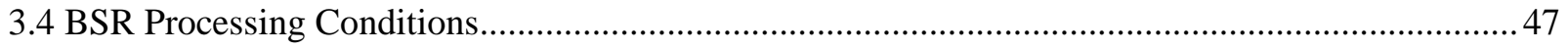

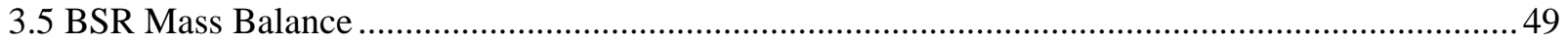

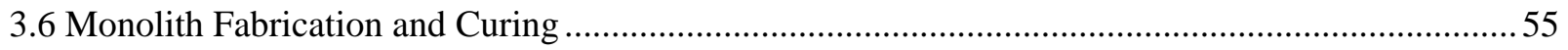

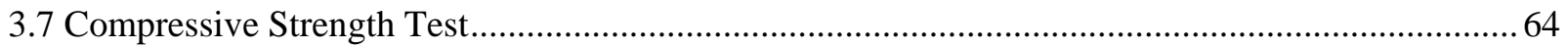

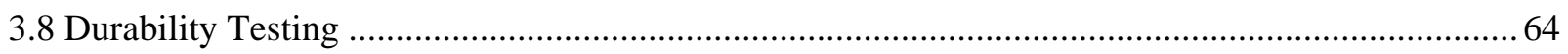

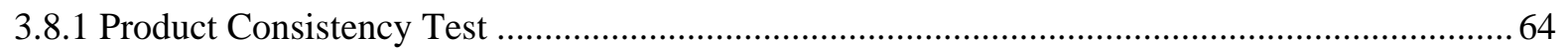

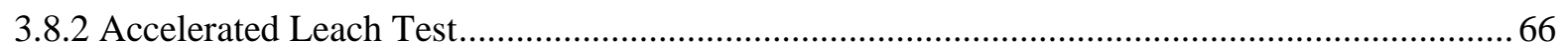

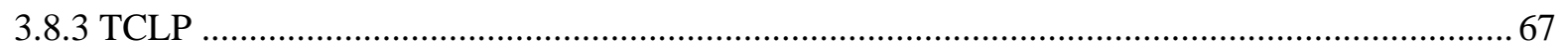

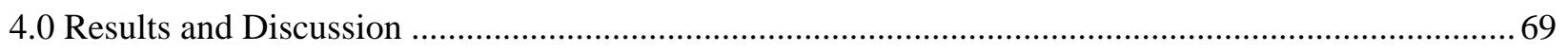

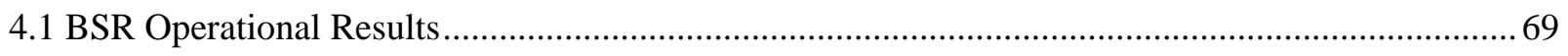

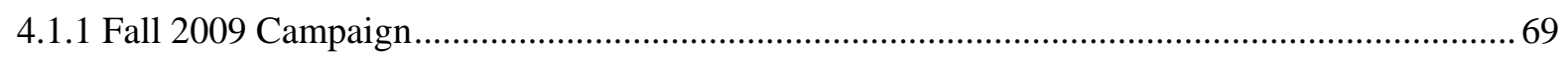

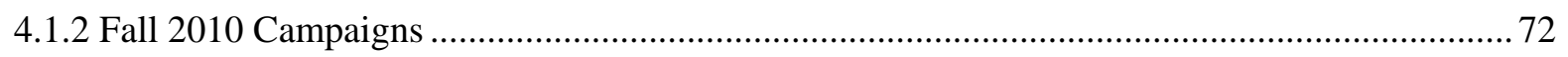

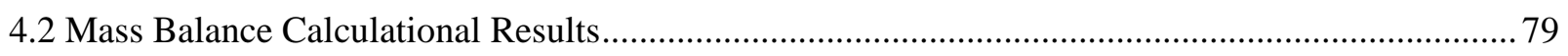

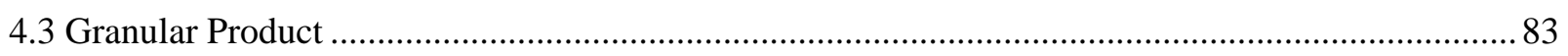

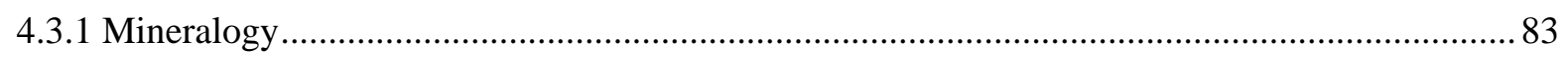

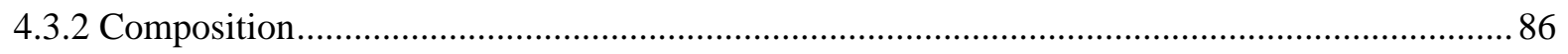

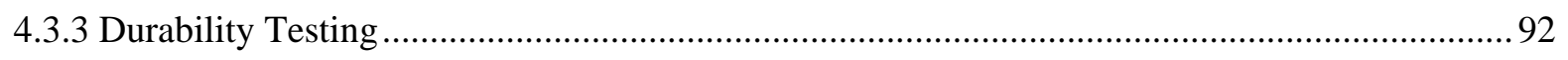

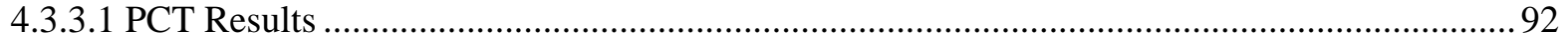




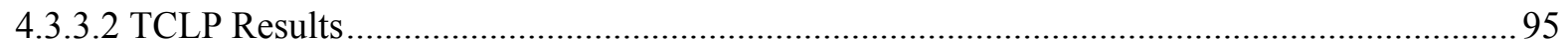

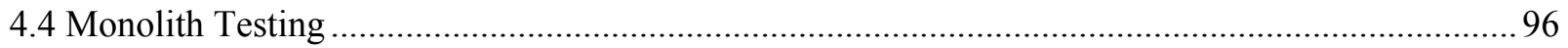

4.4.1 Radioactive Monolith Compression Testing …....................................................................... 96

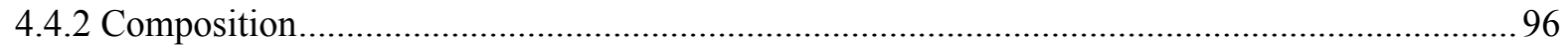

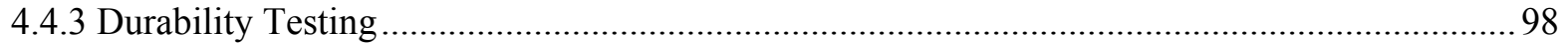

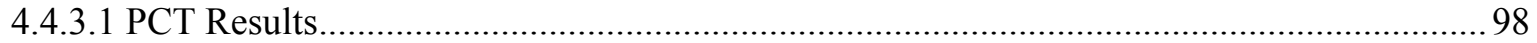

4.4.3.2 Radioactive Monolith ASTM 1308 Testing .................................................................... 101

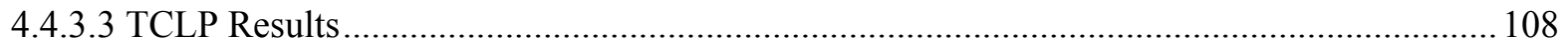

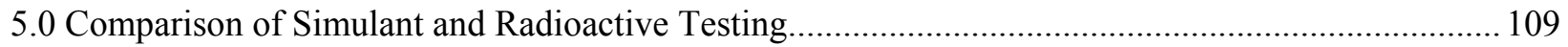

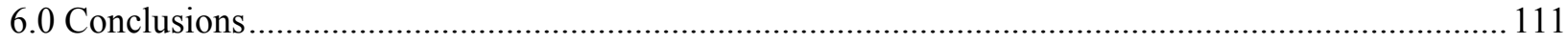

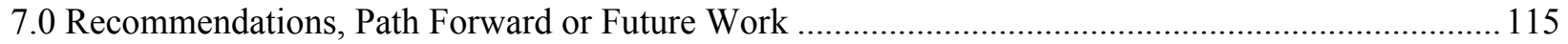

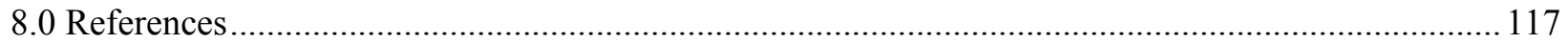

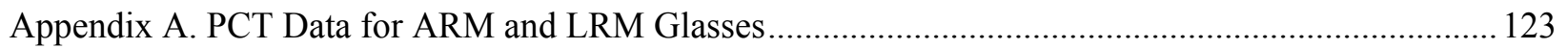

Appendix B. BSR Process Operation Conditions \& Trends for Original Simulant Runs 2009 .............. 124

Appendix C. BSR Process Operation Conditions and trends for Simulant and RAD Runs, 2010 ........... 131

Appendix D. BSR Process Operation Conditions and Trends for Simulant Re-Runs, 2011 .................. 136

Appendix E. Sample Analyses for Simulant WTP SW BSR Campaign in Fall 2010 ............................ 142

Appendix F. Sample Analyses for REPEAT Simulant WTP SW BSR Campaign in Spring 2011 .......... 156

Appendix G. Sample Analyses for Radioactive WTP SW Campaign in Fall 2010............................... 164 


\section{LIST OF TABLES}

Table 1. Sources of FBSR Granular/Monolith Product Durability Testing............................................. 19

Table 2. Radioactive Bench-Scale Reformer (BSR) Tests Being Performed at SRNL ...........................21

Table 3. Substitutional Cations and Oxy-anions in Feldspathoid Mineral Structures ..............................23

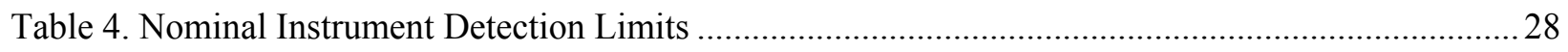

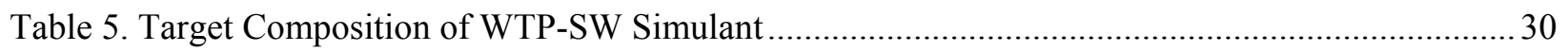

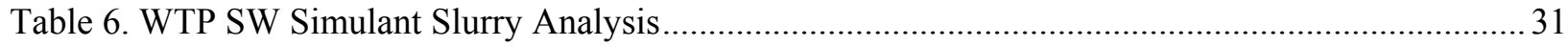

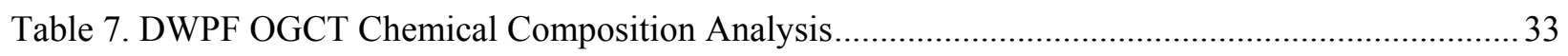

Table 8. Shim Chemicals Added to the DWPF OGCT before Concentration .......................................... 37

Table 9. Additional Shim Chemicals and Radionuclides Added to DWPF OGCT Concentrate................ 37

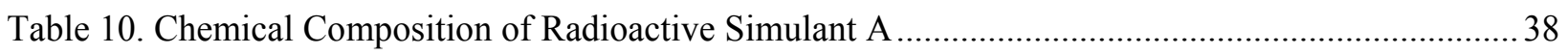

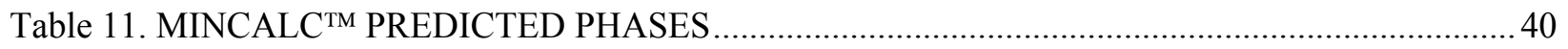

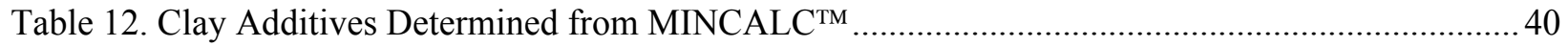

Table 13. Relative Scaling of Process Operating Parameters, FBSR vs BSR ….................................... 48

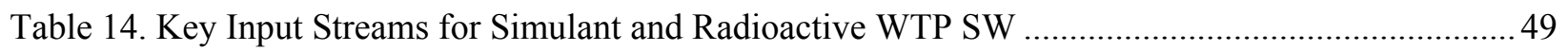

Table 15. Key Output Streams for Simulant and Radioactive WTP SW ................................................50

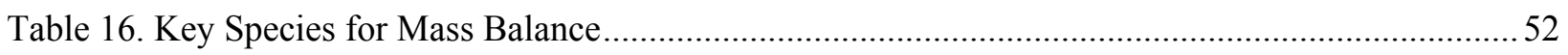

Table 17. Data from Initial SRNL BSR Simulant A WTP SW and HRI ESTD FBSR GEO7 Monolith

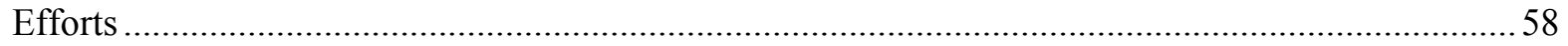

Table 18. Centroid Geopolymer WTP SW Simulant Monolith Recipe Made with Clay ..........................63

Table 19. Centroid Geopolymer Radioactive WTP SW Monolith Recipe Made with Clay.......................63

Table 20. BSR REDOX and LOI Results for Original Simulant Runs Fall 2009 .................................. 70

Table 21. BSR Process Operation Conditions \& Results for Original Simulant Runs Fall 2009..............72

Table 22. BSR REDOX and LOI/LOD for Simulant and Radioactive Runs, Fall 2010 ......................... 73

Table 23. BSR Process Operation Conditions for Simulant and Radioactive Runs, Fall 2010 ................. 74

Table 24. BSR Process Operation Conditions for Simulant Re-Runs, Spring 2011 ................................ 76

Table 25. BSR Process Operation Conditions for WTP SW Re-Runs, Spring 2011 ............................... 77

Table 26. Input Stream Masses for WTP SW Campaigns .................................................................. 79 


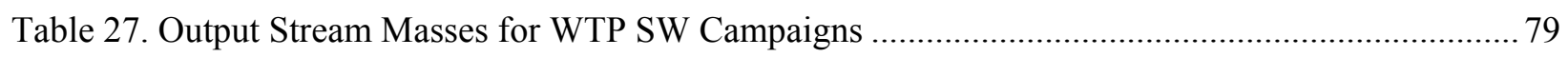

Table 28. Key Species Concentrations for Fall 2010 Simulant Input and Output Streams ....................... 80

Table 29. Key Species Concentrations for Spring 2011 Simulant Input and Output Streams ................... 80

Table 30. Key Species Concentrations for Radioactive Campaign Input and Output Streams ................. 81

Table 31. Key Radioactive Species Concentrations for Radioactive Run Input and Output Streams ........ 81

Table 32. Recoveries for Key Streams and Species for WTP SW Simulant (Fall 2010) ........................ 82

Table 33. Recoveries for Key Streams and Species for WTP SW Simulant Spring 2011 Campaign ......... 83

Table 34. Recoveries for Key Streams and Species for the WTP SW Radioactive Campaign .................. 83

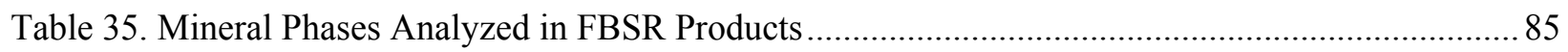

Table 36. Chemical Composition of Fall 2009 WTP SW BSR Simulant Granular Product ...................... 88

Table 37. Chemical Composition of Fall 2010 WTP SW BSR Simulant Granular Product ...................... 89

Table 38. Chemical Composition of Spring 2010 WTP SW BSR Simulant Granular Product.................. 90

Table 39. Chemical Composition of WTP SW Radioactive Granular Product .........................................91

Table 40. PCT Data for Fall 2009 WTP SW Simulant Granular Product ............................................... 92

Table 41. PCT Results for WTP SW BSR Radioactive Granular Product ................................................ 94

Table 42. TCLP Data for WTP SW Fall 2009 Simulant and Spring Radioactive Granular Products ........ 96

Table 43. Chemical Composition of WTP SW Spring 2011 Monolith .................................................. 97

Table 44. Chemical Composition of Radioactive WTP SW Monolith .................................................... 98

Table 45. PCT Data for WTP SW Spring 2011 Simulant and Radioactive Monoliths ............................ 99

Table 46. Leachate Data for Radioactive A Monolith ASTM 1308 ..................................................... 103

Table 47. Calculated Diffusivities and Leach Indexes for Radioactive Monolith ................................... 107

Table 48. TCLP Data for WTP SW Simulant and Radioactive Monoliths............................................ 108

Table 49. PCT Data for WTP SW Simulant and Radioactive Granular Product and Monoliths.............. 109 


\section{LIST OF FIGURES}

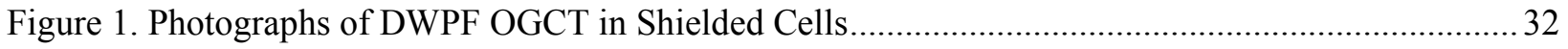

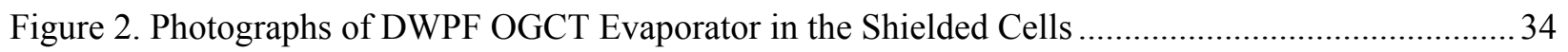

Figure 3. Photographs of DWPF OGCT in Shielded Cells After Concentration..................................... 35

Figure 4. Photographs of DWPF OGCT in Shielded Cells After Final Dilution....................................... 35

Figure 5. XRD Spectra of Insoluble Solids Formed During DWPF OGCT Evaporation........................... 36

Figure 6. $\mathrm{Na}_{2} \mathrm{O}-\mathrm{Al}_{2} \mathrm{O}_{3}-\mathrm{SiO}_{2}$ (NAS) Ternary showing the composition of the WTP-SW waste composition along the base of the triangle $\left(\mathrm{Na}_{2} \mathrm{O}-\mathrm{Al}_{2} \mathrm{O}_{3}\right.$ binary) and the position of the potential clay additives on

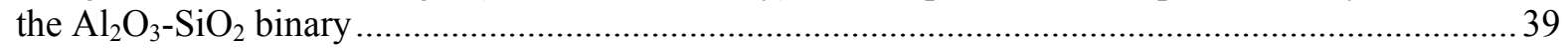

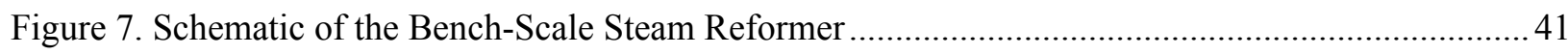

Figure 8. Comparison of the Reactivity of an Individual Particle from the Engineering Scale FBSR and

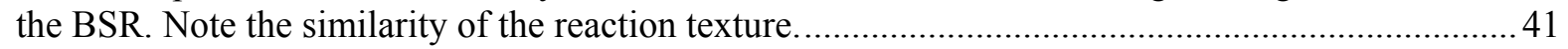

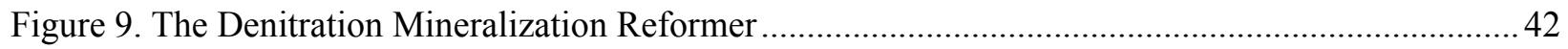

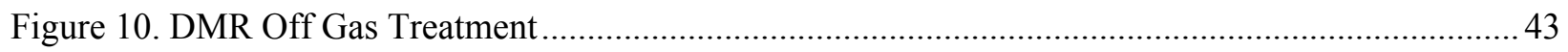

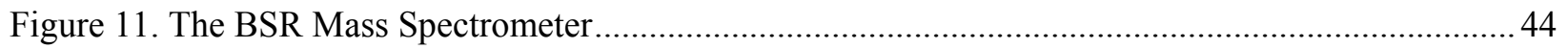

Figure 12. Total Rad System Layout at Cell 4 (Simplified) ............................................................... 46

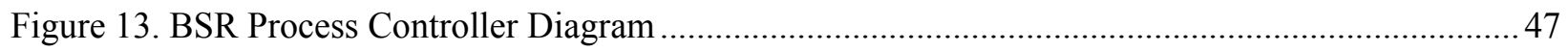

Figure 14. Mass Balance Input and Output Streams for Simulant WTP SW .........................................50

Figure 15. Input and Output Streams for Repeat (Spring 2011) Simulant WTP SW .............................51

Figure 16. Input and Output Streams for Radioactive WTP SW ….....................................................52

Figure 17. Ternary Phase Diagram for Geopolymer Monolith Development .........................................56

Figure 18. Photographs of Initial GEO7 Simulant A Monoliths ..........................................................5

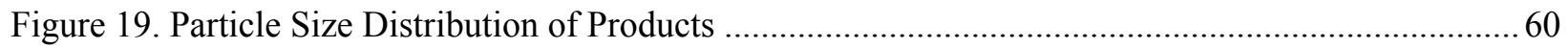

Figure 20. Compressive Strength Trace for GEO-7 Monolith Made with Milled BSR Simulant B ..........61

Figure 21. Compressive Strength Traces for Centroid 1" x 2" Monoliths Made with Clay ...................... 62

Figure 22. Schematic of the Semi-dynamic Monolith Leach Test.........................................................66

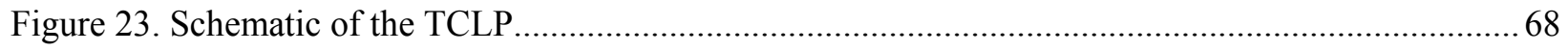

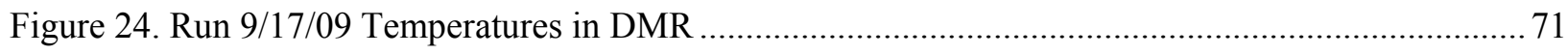

Figure 25. Run 9/17/09 Off Gas Concentrations and Air\% Fed ........................................................ 71 


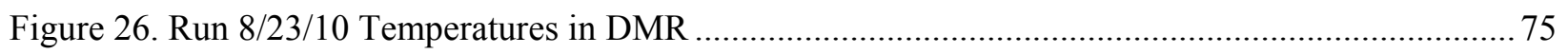

Figure 27. Run 8/23/10 Off Gas Concentrations and Air\% Fed .............................................................. 75

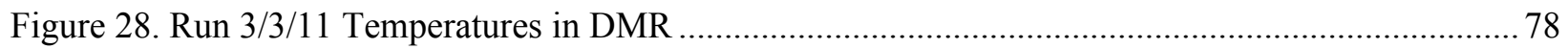

Figure 29. Run 3/3/11 Off Gas Concentrations and Air\% Fed .......................................................... 78

Figure 30. Comparison of mineral phases formed in non-radioactive 2008 ESTD testing of WTP-SW nonradioactive BSR testing and radioactive BSR testing. In all cases the same mineral phases were

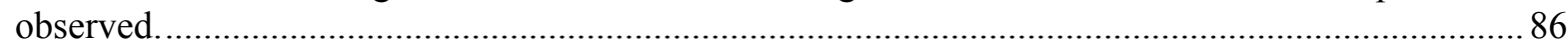

Figure 31. Particle Size Distribution for Fall 2009 BSR PCT Powders ................................................. 93

Figure 32. Particle Size Distribution for WTP SW Radioactive Granular Product PCT Powders (roasted)

Figure 33. Particle Size Distribution for the WTP SW Simulant Monolith PCT Powders (roasted) ....... 100

Figure 34. Particle Size Distribution for the WTP SW Radioactive Monolith PCT Powders (roasted)... 101

Figure 35. Cumulative Fraction Leached for Radioactive A Monolith ASTM 1308. Top Graph shows All Data; Bottom Graph Gives Expanded Scale.................................................................................. 102

Figure 36. Calculated Leach Index Values for Radioactive A Monolith ASTM 1308 .......................... 106

Figure 37. PCT Normalized Release for HRI ESTD Bed, Fines, Blends and Monoliths with Comparison to Current BSR Project PCT Data 
SRNL-STI-2011-00331

Revision 0

\section{LIST OF ABBREVIATIONS}

\begin{tabular}{|c|c|}
\hline ART & Advanced Remediation Technologies \\
\hline ASTM & American Society for Testing and Materials \\
\hline BDL & Below Detection Limit \\
\hline BET-SA & Brunauer-Emmett-Teller - Surface Area \\
\hline BSR & Bench Scale Reactor \\
\hline $\mathrm{COC}$ & Constituents of Concern \\
\hline CWF & Ceramic Waste Form \\
\hline DWPF & Defense Waste Processing Facility \\
\hline DMR & Denitration and Mineralization Reactor \\
\hline DOE & Department of Energy \\
\hline ETF & Effluent Treatment Facility \\
\hline ESTD & Engineering Scale Technology Demonstration \\
\hline FBSR & Fluidized Bed Steam Reformer \\
\hline GP & Granular Product \\
\hline gpm & Gallons per Minute \\
\hline HRI & Hazen Research Inc \\
\hline HLW & High Level Waste \\
\hline HTF & High Temperature Filter \\
\hline INL & Idaho National Laboratory \\
\hline in wc & Inches Water Column \\
\hline IHLW & Immobilized HLW \\
\hline ILAW & Immobilized LAW \\
\hline ICP-AES & Inductively Coupled Plasma Atomic Emission Spectroscopy \\
\hline ICP-MS & Inductively Coupled Plasma Mass Spectroscopy \\
\hline IDL & Instrument Detection Limits \\
\hline IDF & Integrated Disposal Facility \\
\hline IC & Ion Chromatography \\
\hline LAW & Low-Activity Waste \\
\hline LOI & Loss on Ignition \\
\hline $\mathrm{MFC}$ & Materials and Fuel Complex \\
\hline MS & Mass Spectroscopy \\
\hline NAS & $\mathrm{Na}-\mathrm{Al}-\mathrm{Si}$ \\
\hline ORNL & Oak Ridge National Laboratory \\
\hline OGCT & Off-gas Condensate Tank \\
\hline ORP & Office of River Protection \\
\hline PNNL & Pacific Northwest National Laboratory \\
\hline PSD & Particle Size Distribution \\
\hline psi & Pounds per Square Inch \\
\hline PCT & Product Consistency Test \\
\hline REDOX & REDuction/OXidation \\
\hline RCRA & Resource Conservation and Recovery Act \\
\hline RPP & River Protection Project \\
\hline $\mathrm{sccm}$ & Standard Cubic Centimeter per Minute \\
\hline scfm & Standard Cubic Feet per Minute \\
\hline SLM & Standard Liters per Minute \\
\hline SRNL & Savannah River National Laboratory \\
\hline SRS & Savannah River Site \\
\hline
\end{tabular}




$\begin{array}{ll}\text { SEM } & \text { Scanning Electron Microscopy } \\ \text { SAIC } & \text { Science Applications International Corporation } \\ \text { STAR } & \text { Science and Technology Applications Research } \\ \text { SC } & \text { Shielded Cells } \\ \text { SPFT } & \text { Single Pass Flow Through } \\ \text { SBW } & \text { Sodium Bearing Waste } \\ \text { STU } & \text { Solidification Treatment Unit } \\ \text { SALDS } & \text { State Approved Land Disposal Site } \\ \text { TTT } & \text { THOR Treatment Technologies, LLC } \\ \text { THOR } & \text { THermal Organic Reduction } \\ \text { TCLP } & \text { Toxicity Characteristic Leaching Procedure } \\ \text { TPA } & \text { Tri-Party Agreement } \\ \text { UTS } & \text { Universal Treatment Standards } \\ \text { VSL } & \text { Vitreous State Laboratory } \\ \text { WIPP } & \text { Waste Isolation Pilot Plant } \\ \text { WTP } & \text { Waste Treatment and Immobilization Plant } \\ \text { WTP-SW } & \text { WTP - Secondary Waste } \\ \text { WFO } & \text { Work-For-Others }\end{array}$


SRNL-STI-2011-00331

Revision 0

\subsection{Introduction and Background}

The Hanford Site in southeast Washington State has 56 million gallons of radioactive and chemically hazardous wastes stored in 177 underground tanks (DOE/ORP 2010). The U.S. Department of Energy (DOE), Office of River Protection (ORP), through its contractors, is constructing the Hanford Tank Waste Treatment and Immobilization Plant (WTP) to convert the radioactive and hazardous wastes into stable glass waste forms for disposal. Within the WTP, the pretreatment facility will receive the retrieved waste from the tank farms and separate it into two treated process streams. The pretreated high-level waste (HLW) mixture will be sent to the HLW Vitrification Facility, and the pretreated low-activity waste (LAW) stream will be sent to the LAW Vitrification Facility. The two WTP vitrification facilities will convert these process streams into glass, which is poured directly into stainless steel canisters. The immobilized HLW (IHLW) canisters will ultimately be disposed of at an offsite federal repository. The immobilized LAW (ILAW) canisters will be disposed of onsite in the IDF. As part of the pretreatment and ILAW processing, liquid secondary wastes will be generated that will be transferred to the Effluent Treatment Facility (ETF) on the Hanford Site for further treatment. These liquid waste treatment plant secondary wastes (WTP-SW) will be converted to stable solid waste forms that will be disposed of in the IDF. Liquid effluents from the ETF will be discharged through the State Approved Land Disposal Site (SALDS).

The ETF is an existing operating facility on the Hanford Site. It is a Resource Conservation and Recovery Act (RCRA) permitted, multi-waste, treatment and storage unit that can accept Washington State regulated dangerous, low-level, and mixed wastewaters for treatment. The ETF receives, treats, and disposes of liquid effluents from cleanup projects on the Hanford Site. The ETF handles treated effluent under the ETF State Wastewater Discharge Permit and solidified liquid effluents under the Washington State Department of Ecology (Ecology) Dangerous Waste Permit. The ETF lacks the capacity to treat the liquid process effluents from the WTP once it comes online for operations.

The current waste disposal path for the WTP-SW is to process it through the ETF. The WTP-SW is enriched in components such as ${ }^{137} \mathrm{Cs},{ }^{129} \mathrm{I},{ }^{99} \mathrm{Tc}, \mathrm{Cl}, \mathrm{F}$, and $\mathrm{SO}_{4}$ that can volatilize at the vitrification temperature of $1150^{\circ} \mathrm{C}$ in the absence of a continuous cold cap. Among the alternatives to be evaluated for providing the needed capacity for handing the WTP liquid secondary wastes are

- Upgrade ETF, plus construct a Solidification Treatment Unit (STU)

- Upgrade ETF, with new ion exchange facilities, plus construct a STU

- Upgrade ETF, plus recycle evaporator concentrates back to tank farms by truck or pipeline

- Provide additional evaporative capacity, plus use fluidized bed steam reforming.

Fluidized Bed Steam Reforming is being considered for as an option for the STU to solidify the ETF concentrate that would be generated by processing the WTP-SW.

Fluidized Bed Steam Reforming (FBSR) offers a moderate temperature $\left(700-750^{\circ} \mathrm{C}\right)$ continuous method by which WTP-SW and/or LAW wastes can be processed. The FBSR technology can process these wastes into a crystalline ceramic (mineral) waste form that is granular. The granular mineralized waste form that is produced by co-processing waste with kaolin clay in an FBSR process has been shown to be as durable as LAW glass from laboratory leach tests. Monolithing of the granular FBSR product can be used to prevent dispersion during transport or burial/storage but is not necessary for performance. A compressive strength target for the monoliths can be derived from the quoted 500 psi lower limit set forth 
SRNL-STI-2011-00331

Revision 0

in the WTP Contract [1]. Considerable durability testing has been performed by Savannah River National Laboratory (SRNL) and Pacific Northwest National Laboratory (PNNL): see Table 1 and reference 2 for a summary of the work already performed and currently in progress including a demonstration of preliminary acceptance in the Hanford IDF.

\subsection{Pilot and Engineering Scale Testing of Hanford Non-Radioactive LAW and WTP-SW}

Pilot and engineering scale testing has proved successful with non-radioactive simulants of LAW and WTP-SW. The pilot and engineering scale testing and product characterization were performed using rhenium as a surrogate for technetium. Granular FBSR products made with simulated Hanford LAW were tested in 2001-2, 2004 and 2008. The 2001-2 testing was performed by in a 6" diameter pilot scale single reformer with AN-107 simulated waste (Table 1) at Hazen Research Inc. (HRI) in Golden, Colorado. In 2004 a Hanford non-radioactive LAW simulant that represents a 68 tank blend known as the Rassat simulant [3] of Hanford wastes was processed in a 6"diameter single reformer at Science Applications International Corporation (SAIC) Science and Technology Applications Research (STAR) in Idaho Falls, Idaho.

The Rassat simulant was also tested THOR Treatment Technologies, LLC (TTT) at HRI in 2008 in a 15" diameter Engineering Scale Technology Demonstration (ESTD) dual reformer. A WTP-SW simulant based on melter off-gas analyses from Vitreous State Laboratory (VSL) was also tested at HRI in the 15" diameter dual reformer at HRI in 2008. The target concentrations for the RCRA metals and Cs were increased to be detectable in the product and the off-gas. Therefore, the identified metals concentrations were increased by TTT at HRI to ensure detection and enable calculation of system removal efficiencies, product retention efficiencies, and mass balance closure without regard to potential results of those determinations or impacts on product durability response such as TCLP [4]. 
Table 1. Sources of FBSR Granular/Monolith Product Durability Testing

\begin{tabular}{|c|c|c|c|c|c|c|c|c|c|c|c|c|c|c|c|}
\hline $\begin{array}{c}\text { PILOT } \\
\text { SCALE } \\
\text { FACILITY }\end{array}$ & DATE & $\begin{array}{l}\text { FBSR } \\
\text { DIAM. }\end{array}$ & \begin{tabular}{|} 
ACIDIC \\
AND \\
BASIC \\
WASTES
\end{tabular} & $\begin{array}{l}\text { GRANULAR } \\
\text { PCT } \\
\text { TESTING }\end{array}$ & $\begin{array}{c}\text { TCLP } \\
\text { GRANULAR } \\
\text { FORM }\end{array}$ & $\begin{array}{c}\text { GRANULAR } \\
\text { SPFT } \\
\text { TESTING }\end{array}$ & $\begin{array}{c}\text { PRELIM } \\
\text { RA OR } \\
\text { PA }\end{array}$ & $\begin{array}{c}\text { PRODUCT } \\
\text { TESTED }\end{array}$ & COAL & PSD & MONOLITH & $\begin{array}{c}\text { MONOLITH } \\
\text { PCT } \\
\text { TESTING }\end{array}$ & $\begin{array}{c}\text { MONOLITH } \\
\text { SPFT } \\
\text { TESTING }\end{array}$ & \begin{tabular}{|c|} 
MONOLITH \\
ANSI 16.1/ \\
ASTM C1308/ \\
EPA 1315 \\
TESTING \\
\end{tabular} & \begin{tabular}{|c|} 
TCLP \\
OF \\
MONO. \\
FORM \\
\end{tabular} \\
\hline \multicolumn{16}{|c|}{ NON-RADIOACTIVE TESTING } \\
\hline \multirow{2}{*}{ HRI } & \multirow{2}{*}{$\left|\begin{array}{c}12 / 01 \\
\text { Ref } \\
6 \\
\text { below }\end{array}\right|$} & $6 "$ & $\begin{array}{l}\text { LAW } \\
\text { Env. C }\end{array}$ & Ref. 5 & Ref. 5, 6 & $\begin{array}{l}\text { Ref 7,8 } \\
\text { (also PUF } \\
\text { testing) }\end{array}$ & Ref. 9 & Bed & $\begin{array}{l}\text { Removed } \\
\text { By Hand }\end{array}$ & Gaussian & NO & N/A & N/A & $\mathrm{N} / \mathrm{A}$ & N/A \\
\hline & & $6 "$ & $\begin{array}{l}\text { LAW } \\
\text { Env. C }\end{array}$ & $\begin{array}{c}\text { Ref } \\
10,11,12\end{array}$ & $\begin{array}{c}\text { Ref } \\
10,11,12\end{array}$ & None & None & Fines & $\begin{array}{l}\text { Removed } \\
\text { by } 525^{\circ} \mathrm{C} \\
\text { Roasting }\end{array}$ & Gaussian & NO & N/A & N/A & N/A & N/A \\
\hline $\begin{array}{l}\text { SAIC/ } \\
\text { STAR }\end{array}$ & $\begin{array}{c}7 / 03 \\
\operatorname{Ref} 13\end{array}$ & $6 "$ & SBW & $\begin{array}{c}\text { Ref } \\
10,11,12\end{array}$ & $\begin{array}{c}\text { Ref } \\
10,11,12\end{array}$ & None & None & Bed & $\begin{array}{l}\text { Removed } \\
\text { by } 525^{\circ} \mathrm{C} \\
\text { Roasting }\end{array}$ & Gaussian & \multirow{3}{*}{$\begin{array}{c}\text { Yes } \\
\text { (Samples were } \\
\text { combined; } \\
20 \% \text { LAW, 32\% } \\
\text { SBW and } 45 \% \\
\text { Startup Bed }\end{array}$} & \multirow{3}{*}{$\begin{array}{c}\text { Ref } \\
14,15\end{array}$} & NO & NO & NO \\
\hline $\begin{array}{l}\text { SAIC/ } \\
\text { STAR }\end{array}$ & \begin{tabular}{|c|}
$8 / 04$ \\
Ref.16
\end{tabular} & $6 "$ & $\begin{array}{l}\text { LAW } \\
\text { Env. A }\end{array}$ & $\begin{array}{c}\text { Ref } \\
10,11,12\end{array}$ & $\begin{array}{c}\text { Ref } \\
10,11,12\end{array}$ & $\begin{array}{c}\text { Ref } \\
12,17,18\end{array}$ & \begin{tabular}{|c|} 
Data from \\
Ref \\
$12,17,18$ \\
being \\
used
\end{tabular} & \begin{tabular}{|c|} 
Bed \& Fines \\
Separate
\end{tabular} & $\begin{array}{l}\text { Removed } \\
\text { by } 525^{\circ} \mathrm{C} \\
\text { Roasting }\end{array}$ & Gaussian & & & NO & NO & NO \\
\hline $\begin{array}{l}\text { SAIC/ } \\
\text { STAR }\end{array}$ & \begin{tabular}{|c|}
$7 / 04$ \\
and \\
$11 / 04$ \\
Ref.19
\end{tabular} & $6 "$ & SBW & $\begin{array}{c}\text { Ref } \\
10,11,12\end{array}$ & $\begin{array}{c}\text { Ref } \\
10,11,12\end{array}$ & $\begin{array}{c}\text { Ref } \\
12,17\end{array}$ & None & $\begin{array}{c}\text { Bed } \& \text { Fines } \\
\text { Separate }\end{array}$ & $\begin{array}{l}\text { Removed } \\
\text { by } 525^{\circ} \mathrm{C} \\
\text { Roasting }\end{array}$ & Gaussian & & & NO & NO & NO \\
\hline $\begin{array}{l}\text { HRI/ } \\
\text { TTT }\end{array}$ & $12 / 06$ & $15 "$ & SBW & Ref 20 & Ref 20 & None & None & $\begin{array}{c}\text { Bed \& Fines } \\
\text { Separate }\end{array}$ & $\begin{array}{l}\text { Removed } \\
\text { by } 525^{\circ} \mathrm{C} \\
\text { Roasting } \\
\end{array}$ & Gaussian & NO & N/A & N/A & N/A & N/A \\
\hline \multirow[b]{2}{*}{$\begin{array}{l}\text { HRI/ } \\
\text { TTT }\end{array}$} & \multirow[b]{2}{*}{$\begin{array}{l}2008 \\
\text { Ref.4 }\end{array}$} & $15 "$ & $\begin{array}{c}\text { LAW } \\
\text { Env. A }\end{array}$ & Ref 21 & $\operatorname{Ref} 21$ & FY11 & FY11 & $\begin{array}{c}\text { Bed \& Fines } \\
\text { Together }\end{array}$ & $\begin{array}{c}\text { Not } \\
\text { removed }\end{array}$ & $\begin{array}{c}\text { Bi- } \\
\text { Modal }\end{array}$ & YES & \multirow[b]{2}{*}{ Ref. 22} & FY11 & FY11 & FY11 \\
\hline & & $15^{\prime \prime}$ & \begin{tabular}{|c|} 
WTP-SW \\
(melter \\
recycle)
\end{tabular} & Ref 21 & Ref 21 & None & None & $\begin{array}{c}\text { Bed \& Fines } \\
\text { Together }\end{array}$ & $\begin{array}{c}\text { Not } \\
\text { removed }\end{array}$ & $\begin{array}{c}\text { Bi- } \\
\text { Modal }\end{array}$ & YES & & FY11 & FY11 & FY11 \\
\hline \multicolumn{16}{|c|}{ RADIOACTIVE TESTING } \\
\hline $\begin{array}{l}\text { SRNL/ } \\
\text { BSR }\end{array}$ & 2010 & $2.75 "$ & \begin{tabular}{|c|} 
WTP-SW \\
(melter \\
recycle)
\end{tabular} & This study & This study & None & None & Bed & $\begin{array}{c}\text { Not } \\
\text { removed }\end{array}$ & Gaussian & This study & This study & None & This Study & $\begin{array}{l}\text { This } \\
\text { Study }\end{array}$ \\
\hline $\begin{array}{c}\text { SRNL/ } \\
\text { BSR }\end{array}$ & 2010 & $2.7{ }^{\prime \prime}$ & LAW & \multicolumn{12}{|c|}{ W.P. 5-2.1 Scope } \\
\hline
\end{tabular}

PCT - product consistency test method (ASTM C1285-08); TCLP - toxicity characteristic leachate procedure; SPFT - single pass flow-through test method (ASTM C1662); ANSI16.1/ASTM

C1308/EPA 1315 - monolith emersion tests all similar with different leachate replenishment intervals; HRI/TTT - Hazen Research Inc/THOR Treatment Technologies, LLC; SAIC/STAR - Science

Applications International Corporation/Science and Technology Applications Research; LAW Env. - low activity waste envelope A, B, and C; SBW - sodium bearing waste; PSD - particle size distribution; PA - performance assessment; FY11 - Joint program between SRNL, PNNL, ORNL; N/A - not applicable. 
SRNL-STI-2011-00331

Revision 0

Characterization of the 2008 ESTD simulant testing is reported in reference 21 and the WTP-SW target levels are shown below in Table 5 (see Section 3.2.1). Prior to the reference 21 studies, the FBSR bed products and fines had been studied independently to determine the leaching mechanisms and appropriate leach tests to perform. In reference 21, the FBSR bed products were studied separately and together. It was shown that the general type and relative amounts of mineral phases observed in the high temperature filter (HTF) fines are the same as the mineral phases in the FBSR bed products and have comparable durability. The combined FBSR bed products and fines from the two ESTD campaigns were monolithed in a geopolymer formulation (GEO-7) made from fly-ash, sodium silicate, and $\mathrm{NaOH}$ which was chosen from a downselect of different matrices including cements (Portland and 3 high alumina types), Ceramicrete, hydroceramics, and various geopolymers made from kaolin clays. $[14,15,22]$ The durability of the monolithed FBSR waste forms were compared to the granular product responses [22].

BSR testing at SRNL with WTP SW waste surrogates and associated analytical analyses and tests of granular products and monoliths began in the Fall of 2009 as part of a TTT Advanced Remediation Technologies (ART) contract through a Work For Others (WFO) agreement. Work was suspended for a period, and then was continued in the Fall of 2010 through the Spring of 2011. When work was restarted, it was performed in conjunction with work sponsored by EM-31 in an effort to qualify an FBSR waste form that would be a more cost effective treatment/disposal option that should be considered to reduce risk and cost of tank cleanup in the U.S. That effort focuses on Hanford LAW [23]. The EM-31 WP 5.2.1 test program objective is to reduce the risk associated with implementing the FBSR technology as a supplemental LAW treatment by addressing the remaining technical uncertainties and thereby demonstrate acceptable performance for FBSR product after being disposed in a near-surface burial facility.

The 2008 ESTD simulant tests [4], including characterization, monolithing, and durability testing [4, 21, 22] formed the basis for performing the comparative WTP-SW Bench Scale Reactor (BSR) radioactive tests reported on in this study, and referred to as BSR Module A (Table 2). The 2008 ESTD simulant tests [4], including characterization, monolithing, and durability testing [4, 21, 22] also formed the basis for performing the comparative BSR LAW radioactive tests reported on in reference 24 and referred to as BSR Module B (Table 2). Subsequent BSR LAW radioactive tests for Hanford Tank waste from Tank SX-105, Tank AN-103, and a blend of AZ-101/AZ-102 formed the basis for performing the BSR LAW tests reported on in reference 25 (Table 2). 
Table 2. Radioactive Bench-Scale Reformer (BSR) Tests Being Performed at SRNL

\begin{tabular}{|c|c|c|c|}
\hline $\begin{array}{c}\text { BSR } \\
\text { MODULE }\end{array}$ & WASTE ID & SOURCE OF RADIOACTIVE WASTE & $\begin{array}{l}\text { AMOUNT OF } \\
\text { RADIOACTIVE } \\
\text { PRODUCT } \\
\text { PRODUCED }(\mathrm{g}) \\
\end{array}$ \\
\hline $\begin{array}{c}\mathrm{A} \\
\text { [this report] }\end{array}$ & SRS WTP-SW & $\begin{array}{l}\text { Chemical shim of SRS secondary waste } \\
\text { sample from DWPF to resemble Hanford } \\
\text { WTP- Secondary Waste }\end{array}$ & 96 \\
\hline $\begin{array}{c}\text { B } \\
{[24]}\end{array}$ & SRS-LAW & $\begin{array}{l}\text { Chemical shim of SRS LAW (Tank 50) to } \\
\text { resemble Hanford LAW based upon } \\
\text { Rassat's Hanford } 68 \text { tank blend }\end{array}$ & 640 \\
\hline $\begin{array}{c}\mathrm{C} \\
{[25]}\end{array}$ & $\begin{array}{l}\text { Hanford LAW } \\
\text { Sample \#1 (medium } \\
\mathrm{S}, \mathrm{Cl}, \mathrm{F} \text {, and P) }\end{array}$ & $\begin{array}{l}\text { Hanford Tank 241-SX-105 } \\
\text { (medium anions }-\mathrm{SO}_{4}^{2-}, \mathrm{Cl}^{-}, \mathrm{F}^{-} \text {, and } \mathrm{PO}_{4}{ }^{3-} \text { ) }\end{array}$ & 317 \\
\hline $\begin{array}{c}\mathrm{D} \\
{[25]}\end{array}$ & $\begin{array}{l}\text { Hanford LAW } \\
\text { Sample \#2 (low S, } \\
\text { Cl, F, and P) }\end{array}$ & $\begin{array}{l}\text { Hanford Tank 241-AN-103 } \\
\text { (low anions - } \mathrm{SO}_{4}{ }^{2-}, \mathrm{Cl}^{-}, \mathrm{F}^{-} \text {, and } \mathrm{PO}_{4}{ }^{3-} \text { ) }\end{array}$ & 224 \\
\hline $\begin{array}{c}E \\
{[25]}\end{array}$ & $\begin{array}{l}\text { Hanford LAW } \\
\text { Sample \#3 (high Cr } \\
\text { and high S) }\end{array}$ & $\begin{array}{l}\text { Hanford Tank 241-AZ-101/102 composite } \\
\text { (high } \mathrm{SO}_{4}^{2-}, \text { high } \mathrm{Cr} \text { ) }\end{array}$ & TBD \\
\hline
\end{tabular}

\subsection{Mineral Waste Forms: "Historical Perspective Vs Commercialization"}

Crystalline (ceramic/mineral) waste forms made by moderate temperature $\left(700-750^{\circ} \mathrm{C}\right)$ thermal treatment have not been as intensely investigated as those formed at high temperatures $\left(1000-1500^{\circ} \mathrm{C}\right)$ by pressing and sintering (SYNROC, supercalcine ceramics, tailored ceramics, and Pu ceramics) [26]. However, crystalline waste forms made from clay have been studied almost continuously since 1953 [26,27]. Often the high temperatures used for sintering created sodalite-cancrinite mineral assemblages. In 1981, Roy [28] proposed low temperature hydrothermally processed low solubility phase assemblages consisting of the micas, apatite, pollucite, sodalite-cancrinite, and nepheline, many of which could be made from reaction of various clays (kaolin, bentonite, illite) with waste.

Clay based crystalline (ceramic/mineral) waste forms were not pursued in the late 1970's and early 1980's because there was no continuous commercial technology available that could process the waste/clay mixtures in a hydrothermal environment [26]. A commercial facility to continuously process radioactive wastes at moderate temperatures in a hydrothermal steam environment was built by Studsvik in Erwin, Tennessee in 1999 [29,30]. The Erwin facility uses a steam reforming technology designated as the THermal Organic Reduction (THOR ${ }^{\circledR}$ ) process to pyrolyze ${ }^{137} \mathrm{Cs}$ and ${ }^{60} \mathrm{Co}$ containing organic resins from commercial nuclear facilities. The Erwin facility has the capability to process a wide variety of solid and liquid streams including: ion exchange resins, charcoal, graphite, sludge, oils, solvents, and cleaning solutions at radiation levels of up to $400 \mathrm{R} / \mathrm{hr}$.

If kaolin clay is added to an alkali-rich waste during FBSR processing a "mineralized" waste form is produced that is composed of various Na-Al-Si (NAS) feldspathoid minerals discussed above (i.e. sodalites are the potential host minerals for the halides; nosean which has a larger cage structure is the host mineral for sulfate or sulfide species, Re and ${ }^{99} \mathrm{Tc}$; and nepheline sequesters the remaining alkali by nano-scale reaction of the clay and waste). Bench scale, pilot scale, and engineering scale tests have all formed this mineral assemblage with a variety of legacy United States Department of Energy (US DOE) waste simulants. Illite type clay was tested at the bench scale and shown to form dehydroxylated micas 
(potential host for future used nuclear fuel recycling wastes including lanthanides, $\mathrm{Cs}, \mathrm{Sr}, \mathrm{Ba}, \mathrm{Rb}, \mathrm{Tl}$, etc.) by similar nano-scale reaction of clay and waste [31].

The commercialization of the FBSR technology at the Erwin, Tennessee facility has created interest in this technology for the immobilization of a wide variety of radioactive wastes across the US DOE complex. Of special relevance is the capability of the FBSR technology to destroy organics while converting alkali/alkaline earth/rare earth salts to aluminosilicate minerals that are suitable for direct geological disposal and/or to carbonate or silicate species for subsequent vitrification or disposal.

An FBSR facility is being designed and constructed at the Idaho National Laboratory (INL) for treatment of their Sodium Bearing Waste (SBW) for potential disposal in the Waste Isolation Pilot Plant (WIPP) $[13,16]$ in the US. Another facility is being considered for use at the Savannah River Site (SRS) to convert a salt supernate waste (Tank 48) containing nitrates, nitrites, and insoluble cesium tetraphenyl borate (CsTPB), to carbonate or silicate minerals which are compatible with subsequent vitrification in the Defense Waste Processing Facility (DWPF) [32,33]. Pilot-scale testing has also included a variety of DOE wastes producing aluminosilicate waste forms for INL's SBW and Hanford's LAW [6, 19] and LAW melter recycle (referred to throughout this paper as WTP SW).

\subsection{Waste Form Mineralogy and Performance}

The fluidizing steam used in FBSR processing creates a hydrothermal environment which promotes mineral formation. Clays become amorphous at the nano-scale at the FBSR processing temperature because clays lose their hydroxyl groups between $550-750^{\circ} \mathrm{C}$ which destabilizes the $\mathrm{Al}$ atoms in their structure. Once the Al cation is destabilized the clay becomes amorphous and species in the waste "activate" the unstable Al cation to form new mineral structures. The hydrothermal environment created by the steam and the nano-scale reactivity of the clay catalyze mineralization allowing formation and templating at moderate temperatures. Kaolin clay has been found to template the feldspathoids and the illite clays have been found to template the dehydroxylated micas as radionuclide hosts [31]. Additional iron bearing co-reactants can be added during processing to stabilize any multivalent hazardous species present in a waste in durable spinel phases, i.e. $\mathrm{Cr}, \mathrm{Ni}, \mathrm{Pb}$ iron oxide minerals.

The Na-Al-Si (NAS) mineral waste forms are comprised of nepheline (hexagonal $\mathrm{Na}_{\mathrm{x}} \mathrm{Al}_{\mathrm{y}} \mathrm{Si}_{\mathrm{z}} \mathrm{O}_{4}$ where $\mathrm{x}, \mathrm{y}$, and $\mathrm{z}$ nominally each are a value of 1 ) and other feldspathoid mineral phases which have large cages that trap anion constituents such as $\mathrm{Na}_{2} \mathrm{SO}_{4}$ (nosean), $\mathrm{NaF}, \mathrm{NaI}, \mathrm{NaCl}$ (sodalite nominally $\mathrm{Na}_{8}\left[\mathrm{Al}_{6} \mathrm{Si}_{6} \mathrm{O}_{24}\right]\left(\mathrm{Cl}_{2}\right.$ ) $\mathrm{Na}_{2} \mathrm{MoO}_{4}, \mathrm{NaTcO}_{4}, \mathrm{NaReO}_{4}$. The feldspathoid mineral nepheline has a ring type structure. A second nepheline phase that has been found is a sodium rich cubic derivative, $\left(\mathrm{Na}_{2} \mathrm{O}\right)_{0.33} \mathrm{NaAlSiO}_{4},{ }^{f}$ with large twelve-fold oxygen cage like voids [34]. Nepheline also accommodates $\mathrm{Cs}, \mathrm{Sr}$, $\mathrm{Ti}$, and $\mathrm{Ca}$ (Table 3).

The NAS cage structures are typical of sodalite and/or nosean phases where the cavities in the cage structure bond oxyanions and/or radionuclides to the alumino-silicate tetrahedra and to sodium in the mineral structure. The sodalite minerals are known to accommodate $\mathrm{Be}$ in place of $\mathrm{Al}$ and $\mathrm{S}$ in the cage structure along with $\mathrm{Fe}, \mathrm{Mn}$, and $\mathrm{Zn}$ (Table 3). These cage-structured sodalites were minor phases in HLW supercalcine waste forms ${ }^{1}$ and were found to retain Cs, Sr, and Mo into the cage-like structure as indicated in Table 3. In addition, sodalite structures are known to retain $\mathrm{B}[35,44]$ and $\mathrm{Ge}[36]$ in the cage like structures. Waste stabilization at the Materials \& Fuels Complex (MFC) at the INL currently uses a glass-bonded sodalite ceramic waste form (CWF) for containment of I from electrorefiner wastes from the EBR II fast breeder reactor [37,38].

Powder Diffraction File (PDF) \#39-0101

Supercalcines were the high temperature silicate based "mineral" assemblages proposed for HLW waste stabilization in the United States (1973-1985). 
SRNL-STI-2011-00331

Revision 0

Table 3. Substitutional Cations and Oxy-anions in Feldspathoid Mineral Structures

\begin{tabular}{|c|c|c|}
\hline $\begin{array}{l}\text { NEPHELINE - KALSILITE } \\
\text { STRUCTURES* }\end{array}$ & $\begin{array}{c}\text { SODALITE } \\
\text { STRUCTURES** }\end{array}$ & NOSEAN STRUCTURES \\
\hline $\begin{array}{l}\text { NaxAlySizO }_{4}[39] \\
\text { where } x=1-1.33, y \text { and } z=0.55-1.1\end{array}$ & $\left.\mathrm{Na}_{6} \mathrm{Al}_{6} \mathrm{Si}_{6} \mathrm{O}_{24}\right](\mathrm{NaCl})_{2}[39]$ & $\left.\mathrm{Na}_{6} \mathrm{Al}_{6} \mathrm{Si}_{6} \mathrm{O}_{24}\right]\left(\mathrm{Na}_{2} \mathrm{SO}_{4}\right)[39,40]$ \\
\hline $\mathrm{KAlSiO}_{4}[39]$ & $\left.\mathrm{Na}_{6} \mathrm{Al}_{6} \mathrm{Si}_{6} \mathrm{O}_{24}\right](\mathrm{NaFl})_{2}[39]$ & $\left.\mathrm{Na}_{6} \mathrm{Al}_{6} \mathrm{Si}_{6} \mathrm{O}_{24}\right]\left(\mathrm{Na}_{2} \mathrm{MoO}_{4}\right)[39,41]$ \\
\hline $\mathrm{K}_{0.25} \mathrm{Na}_{0.75} \mathrm{AlSiO}_{4}[39]$ & $\left.\mathrm{Na}_{6} \mathrm{Al}_{6} \mathrm{Si}_{6} \mathrm{O}_{24}\right](\mathrm{NaI})_{2}[40]$ & {$\left[\mathrm{Na}_{6} \mathrm{Al}_{6} \mathrm{Si}_{6} \mathrm{O}_{24}\right]\left((\mathrm{Ca}, \mathrm{Na}) \mathrm{SO}_{4}\right)_{1-2}[42]$} \\
\hline$\left(\mathrm{Na}_{2} \mathrm{O}\right)_{0.33} \mathrm{NaAlSiO}_{4}[34]$ & $\left.\mathrm{Na}_{6} \mathrm{Al}_{6} \mathrm{Si}_{6} \mathrm{O}_{24}\right](\mathrm{NaBr})_{2}[40]$ & $\begin{array}{l}{\left[(\mathrm{Ca}, \mathrm{Na})_{6} \mathrm{Al}_{6} \mathrm{Si}_{6} \mathrm{O}_{24}\right]\left((\mathrm{Ca}, \mathrm{Na}) \mathrm{S}, \mathrm{SO}_{4}, \mathrm{Cl}\right)_{\mathrm{x}}\left[\mathrm{PDF}^{f}\right.} \\
\# 17-749]\end{array}$ \\
\hline $\mathrm{CsAlSiO}_{4}[39]$ & $\begin{array}{l}{\left[\mathrm{Na}_{6} \mathrm{Al}_{6} \mathrm{Si}_{6} \mathrm{O}_{24}\right]\left(\mathrm{NaReO}_{4}\right)_{2}} \\
{[43]}\end{array}$ & \\
\hline $\mathrm{RbAlSiO}_{4}[39]$ & $\begin{array}{l}{\left[\mathrm{Na}_{6} \mathrm{Al}_{6} \mathrm{Si}_{6} \mathrm{O}_{24}\right]\left(\mathrm{NaMnO}_{4}\right)_{2}} \\
{[44]}\end{array}$ & \\
\hline$\left(\mathrm{Ca}_{0.5}, \mathrm{Sr}_{0.5)} \mathrm{AlSiO}_{4}[39]\right.$ & $\begin{array}{l}\left(\mathrm{NaAlSiO}_{4}\right)_{6}\left(\mathrm{NaBO}_{4}\right)_{2}[35, \\
45]\end{array}$ & \\
\hline$(\mathrm{Sr}, \mathrm{Ba}) \mathrm{Al}_{2} \mathrm{O}_{4}[39]$ & $\mathrm{Mn}_{4}\left[\mathrm{Be}_{3} \mathrm{Si}_{3} \mathrm{O}_{12}\right] \mathrm{S}[40]$ & \\
\hline $\mathrm{KFeSiO}_{4}[39]$ & $\mathrm{Fe}_{4}\left[\mathrm{Be}_{3} \mathrm{Si}_{3} \mathrm{O}_{12}\right] \mathrm{S}[40]$ & \\
\hline$\left(\mathrm{Na}, \mathrm{Ca}_{0.5}\right) \mathrm{YSiO}_{4}[44]$ & $\mathrm{Zn}_{4}\left[\mathrm{Be}_{3} \mathrm{Si}_{3} \mathrm{O}_{12}\right] \mathrm{S}[40]$ & \\
\hline \multicolumn{3}{|l|}{$(\mathrm{Na}, \mathrm{K}) \mathrm{LaSiO}_{4}[44]$} \\
\hline$\left(\mathrm{Na}, \mathrm{K}, \mathrm{Ca}_{0.5}\right) \mathrm{NdSiO}_{4}[44]$ & & \\
\hline
\end{tabular}

* Iron, $\mathrm{Ti}^{3+}, \mathrm{Mn}, \mathrm{Mg}, \mathrm{Ba}, \mathrm{Li}, \mathrm{Rb}, \mathrm{Sr}, \mathrm{Zr}, \mathrm{Ga}, \mathrm{Cu}, \mathrm{V}$, and $\mathrm{Yb}$ all substitute in trace amounts in nepheline.[ 39]

** Higher valent anionic groups such as $\mathrm{AsO}_{4}{ }^{3-}$ and $\mathrm{CrO}_{4}{ }^{2-}$ form $\mathrm{Na}_{2} \mathrm{XO}_{4}$ groups in the cage structure where $\mathrm{X}=\mathrm{Cr}$, $\mathrm{Se}, \mathrm{W}, \mathrm{P}, \mathrm{V}$, and As [44]

$f \quad$ Powder Diffraction File

The Na-Al-Si (NAS) waste form is primarily composed of nepheline (ideally $\mathrm{NaAlSiO}_{4}$ ) and the sodalite family of minerals (ideally $\mathrm{Na}_{8}\left[\mathrm{AlSiO}_{4}\right]_{6}(\mathrm{Cl})_{2}$ which includes nosean (ideally $\mathrm{Na}_{8}\left[\mathrm{AlSiO}_{4}\right]_{6} \mathrm{SO}_{4}$ ). Semivolatile oxyanions such as $\mathrm{ReO}_{4}^{-}, \mathrm{TcO}_{4}^{-}$, (both of which are specifically in the +7 oxidation state) are expected to replace sulfate in the larger cage structured nosean and halides such as $\mathrm{I}^{-}$and $\mathrm{F}^{-}$are expected to replace chlorine in the nosean-sodalite mineral structures - immobilizing them. The release of semivolatile radionuclides ${ }^{99} \mathrm{Tc}$ and ${ }^{129} \mathrm{I}$ from granular NAS waste forms was hypothesized during preliminary performance testing to be limited by nosean solubility as the Re releases during durability testing tracked the sulfate releases. $[7,8,9]$ The predicted performance of the NAS waste form was found to be equivalent or better than the glass waste form in the initial supplemental LAW treatment technology risk assessment in the granular form [9]. The durable granular product can be further macro-encapsulated into a durable waste form using 'binders' such as a geopolymer ( $\mathrm{Na}, \mathrm{Al}, \mathrm{Si}$ ) structures to meet transportation and disposal requirements but this is not necessary for performance. 
SRNL-STI-2011-00331

Revision 0

BLANK PAGE

Page 24 of 177 
SRNL-STI-2011-00331

Revision 0

\subsection{Objectives and Quality Assurance for WTP SW Bench Scale Reformer Testing}

The principal objectives of the Hanford WTP SW test program were to:

- Demonstrate, with the BSR equipment, the production of radioactive granular product and monolith final waste form comparable to that generated via non-radioactive simulant in prior ESTD testing.

- Generate adequate quantities of granular product for characterization, durability testing, and other analyses as required.

- Determine mineralized product composition and performance by analysis of the product solids via XRD and chemical analysis of product samples

- Generate monolith products from the mineralized WTP SW products for characterization, durability testing, and other analyses as required. The retention and determination of leach resistance of cesium, iodine, and rhenium in the product are key elements of this objective.

- Analyze monolith properties with respect to chemical characteristics and product durability.

- Perform TCLP, PCT, leachability, and compressibility analyses.

To achieve these objectives SRNL obtained a recycle stream sample from the Defense Waste Processing Facility (DWPF). The DWPF radioactive sample was evaporated 20X and then trimmed with radioactive ${ }^{99}$ Tc and mixtures of ${ }^{129}$ I (radioactive) ${ }^{125}$ I (radioactive) to make the DWPF sample mimic the anticipated WTP SW composition at Hanford. During the BSR processing, kaolin clay was added to the modified DWPF melter recycle waste to form the mineralized waste form between $650^{\circ}-750^{\circ} \mathrm{C}$. The mineralized waste form product was granular and was characterized and tested. A portion of the granular product was made into a monolith. The monolith was then subjected to a compression test. Crushed pieces of the radioactive monolith resulting from the compression testing were then re-characterized and subjected to PCT analyses. A radioactive monolith was leach tested according to ASTM C1308. Both the granular product and the monolith product were leach tested using the EPA TCLP procedure performed by a certified offsite laboratory.

Simulant was tested in the non-radioactive BSR in order to provide (1) optimization of processing parameters for radioactive testing, (2) granular samples for testing the durability response of the BSR product in comparison with the TTT pilot scale product, and (3) granular products to monolith and compare (durability and compressive strength) to the monolithic waste forms prepared from the ESTD pilot.

The simulant and radioactive sample preparation, processing and waste form testing performed at the Savannah River National Laboratory (SRNL) was conducted in accordance with the ASME NQA-1 based quality assurance program. All analyses were conducted at SRNL in accordance with the quality assurance program given in the Task Technical and Quality Assurance document "Evaluation of Radionuclide THOR ${ }^{\circledR}$ Mineralized Waste Forms (Granular and Monolith) for the DOE Advanced Remediation Technologies (ART) Phase 2 Project” (SRNL-STI-2009-00179, 8/27/09). The TTQAP was written based on the original Statement of Work described in the Work for Others Agreement WFO-09003 (4-2-2009) between SRNS and Thor Treatment Technologies, LLC, entitled "Evaluation of Radionuclide THOR ${ }^{\circledR}$ Mineralized Waste Forms (Granular and Monolith) for the DOE Advanced Remediation Technologies (ART) Phase 2 Project”. The analytical data collected are recorded in laboratory notebook SRNL-NB-2008-00070. The Benchscale Reformer run parameters were documented in SRNL-NB-2009-00115 and SRNL-NB-2011-00004. The monolith fabrication, PCT testing, TCLP testing, and ASTM 1308/ANSI 16.1 testing are documented in SRNL-NB-2010-00081. 
SRNL-STI-2011-00331

Revision 0

BLANK PAGE

Page 26 of 177 


\subsection{Experimental Procedure}

In contrast to most waste form development programs where bench scale research precedes pilot scale testing, the FBSR process has been run at the pilot and engineering scale (Table 1) with simulants but not at the bench scale with either simulants or radioactive wastes. SRNL has successfully operated a BSR in the SRNL Shielded Cells (SC) $[46,47]$. The BSR is a unique SRNL design and this radioactive capability does not exist elsewhere. SRNL also has unique expertise, analytical chemistry skills, and equipment for monolithing the granular FBSR product and measuring durability of waste forms. SRNL currently has two BSR's - one for non-radioactive testing and one for radioactive testing. Testing with the nonradioactive BSR always precedes radioactive testing as the run parameters must be determined so that the product chemistry and the gas reactions in the BSR match those of the ESTD pilot scale operations. In order to ensure this, the non-radioactive BSR product mineralogy is checked after each campaign, the REDuction/OXidation (REDOX) is measured after each campaign, and the loss-on-ignition (LOI) at $525^{\circ} \mathrm{C}$ is measured as an indication of the amount of residual coal ${ }^{f}$ in the product. Each of these parameters has specific targets for the runs based on past history with the feed or technical limitations of the chemistry and BSR process. To provide the radioactive sample for testing, a radioactive DWPF melter recycle sample was obtained, analyzed, shimmed with nonradioactive chemicals to represent the WTPSW and evaporated to produce the WTP-SW (Module A RAD) feed. The radioactive products were used for durability testing in both the granular and the monolithic form to provide needed tie backs to durability testing of non-radioactive product made in the BSR and ESTD $[2,10,11,12,14,15,17,18$, 21,22 and Table 1]. A process control strategy for the FBSR mineralizing process was developed by SRNL in 2004 and is based on composition control in the NAS oxide system. The process control strategy is known as MINCALC ${ }^{\text {TM }}$ and has been used to control the SAIC-STAR campaigns, the ESTD campaigns and the BSR campaigns. MINCALC ${ }^{\mathrm{TM}}$ controls the FBSR product in the region of nepheline/sodalite formation and can be used to calculate the theoretical weight percent of each of the mineral phases.

\subsection{Characterization}

Elemental and anion compositions of the BSR granular product and monolith materials were measured for the simulant and radioactive products. Elemental analyses were performed on both lithium tetraborate fusion $\left(1000^{\circ} \mathrm{C}\right)$ and sodium peroxide fusion $\left(650^{\circ} \mathrm{C}\right)$ for the initial Simulant A granular products from Fall 2009. These methods used nominally $0.1 \mathrm{~g}$ of powder solid sample to $0.1 \mathrm{~L}$ of dissolved solution, and $0.15 \mathrm{~g}$ of powder solid to $0.250 \mathrm{~L}$ of dissolved solution, respectively. The methods have previously been described in detail [10]. The digestion methods for elemental (cation) analysis involve the use of acids for dissolution. A KOH fusion method with water uptake was used for sample dissolution to obtain anion analyses using typically $0.5 \mathrm{~g}$ of solid powder to $0.05 \mathrm{~L}$ of dissolved solution. All elemental cation concentrations (except for I, Re and Cs) were determined by Inductively Coupled Plasma Atomic Emission Spectroscopy (ICP-AES). The Re, Cs and I were measured by Inductively Coupled Plasma Mass Spectroscopy (ICP-MS). Other anions were measured by Ion Chromatography (IC). A separate Aqua Regia dissolution method involving the use of $\mathrm{HCl}$ and $\mathrm{HNO}_{3}$ in sealed vessels at temperature of 110 to $115^{\circ} \mathrm{C}$ was used to replace the lithium tetraborate method primarily to optimize the accurate determination of Re in these minerals.

Table 4shows the nominal instrument detection limits (IDLs) for the various analyses and the solid to liquid ratios for the various dissolution methods (PerFus $=$ sodium peroxide fusion; Li-TetraBorate $=$

\footnotetext{
${ }^{f}$ coal is used in the FBSR as the source of auto-catalytic heating and this is described in several papers and patents available at www.thortt.com.
} 
Lithium Tetraborate fusion; $\mathrm{KOH}=$ potassium hydroxide fusion). The reported method uncertainty for the ICP-AES and IC-Anion is $\pm 10 \%$, while the reported method uncertainty for the ICP-MS is $\pm 20 \%$. These data indicate that the lowest detection level for cations in the BSR solids is in the range of 0.01 to $0.017 \mathrm{wt} \%$ for ICP-AES. The ICP-MS data was performed on instrumentation using nominal IDLs of $0.05 \mathrm{ppb}$ giving detection limits on the order of $5 \mathrm{E}-6 \mathrm{wt} \%$. The IC-anion method has a higher IDL of $1,000 \mathrm{ppb}(1 \mathrm{mg} / \mathrm{L})$ or about $0.04 \mathrm{wt} \%$ in the dissolved solids.

Table 4. Nominal Instrument Detection Limits

\begin{tabular}{|l|c|l|l|l|c|}
\hline $\begin{array}{c}\text { Analytical } \\
\text { Method }\end{array}$ & $\begin{array}{c}\text { IDL } \\
\text { ug/L (ppb) }\end{array}$ & $\begin{array}{c}\text { Digestion } \\
\text { Method }\end{array}$ & $\begin{array}{c}\text { Elements } \\
\text { Measured }\end{array}$ & $\begin{array}{c}\text { Ratio } \\
\text { gram:Liter }\end{array}$ & $\begin{array}{c}\text { Detection Level } \\
(\mathbf{w t} \%)\end{array}$ \\
\hline \multirow{3}{*}{ ICP-AES } & \multirow{2}{*}{100} & PerFus & Cations (no Na) & $0.15 / 0.25$ & 0.017 \\
\cline { 2 - 6 } & & Li-TetraBorate & Cations (no Li, B) & $0.1 / 0.1$ & 0.010 \\
\cline { 2 - 6 } & 100 & Aqua Regia & Cations (no Si) & $0.25 / 0.1$ & 0.005 \\
\hline \multirow{3}{*}{ ICP-MS } & \multirow{2}{*}{0.05} & PerFus & \multirow{2}{*}{ Cs, Re } & $0.15 / 0.25$ & 0.000008 \\
\cline { 2 - 6 } & & Li-TetraBorate & Re & $0.1 / 0.1$ & 0.000005 \\
\cline { 2 - 6 } & 0.05 & Aqua Regia & Re & $0.25 / 0.1$ & 0.000002 \\
\hline IC-Anion & 1,000 & KOH & Anions & $0.25 / 0.1$ & 0.040 \\
\hline ICP-MS - Iodide & 1 & KOH & Iodide & $0.25 / 0.1$ & 0.00004 \\
\hline
\end{tabular}

REDOX (iron (II) to total iron ratio) was determined on samples using a dissolution and absorption spectroscopy method [48]. As received samples were also examined by powder X-ray Diffraction (XRD) to investigate the formation of the mineral phases in the FBSR waste forms. The XRD method gives information on the specific crystalline phases present by comparison to reference library spectra. Although this method is not used with any internal standards to allow for quantitative measurement of the various crystalline phases, it does provide information as to the 'major' and 'minor' and 'trace' phases present by intercomparison of the main peaks of each crystalline pattern within a given sample. The moisture content and residual coal content of the BSR granular products and monoliths were determined by heating in an oven for 2 to 3 hours at $105^{\circ} \mathrm{C}$ (LOD), followed by heating in a furnace for 5 to 6 hours at $525^{\circ} \mathrm{C}$ (LOI). An extra heating step was included for the crushed monolith powders at $250{ }^{\circ} \mathrm{C}$ to determine the 'unbound' water associated with the monolith matrix. It should be noted that all granular product and monolith samples for this project were simply stored in covered containers on the bench top at ambient temperatures, i.e., no special attempts were made to control exposure to air or humidity.

Standard radioanalytical chemical methods were used in this project to measure key radionuclides such as ${ }^{137} \mathrm{Cs},{ }^{99} \mathrm{Tc},{ }^{129} \mathrm{I}$ and ${ }^{125} \mathrm{I}$. For ${ }^{99} \mathrm{Tc}$ analyses, ${ }^{99 \mathrm{~m}} \mathrm{Tc}$ tracer was generated in the SRNL ${ }^{252} \mathrm{Cf}$ neutron activation analysis facility by activating ${ }^{99} \mathrm{Mo}$ to ${ }^{99 \mathrm{~m}} \mathrm{Tc}$ via neutron irradiation. The ${ }^{99 \mathrm{~m}} \mathrm{Tc}$ was extracted from the ${ }^{99}$ Mo target material with methyl isobutyl ketone (MIBK). ${ }^{99 \mathrm{~m}} \mathrm{Tc}$ tracer was added to aliquots of sample. The technetium species were extracted from the matrix using an Aliquat-336 based solid phase extractant. ${ }^{99} \mathrm{Tc}$ concentrations were measured by liquid scintillation analysis. ${ }^{99 \mathrm{~m}} \mathrm{Tc}$ yields were measured for each aliquot with a NaI well gamma spectrometer, and were used to correct the ${ }^{99} \mathrm{Tc}$ values for any technetium losses incurred during the radiochemical separations. The aqua regia dissolutions were used to prepare aliquots for ${ }^{99} \mathrm{Tc}$ analysis from dissolved mineral product.

For the iodide ${ }^{129} \mathrm{I} \&{ }^{125} \mathrm{I}$ isotopes, KI carrier was added to sample aliquots. Actinide and Ammonium Molybdophosphate (AMP) resins were then added to the mixture to facilitate removal of interfering isotopes. Sodium sulfite was added to the material to reduce the iodine. Silver nitrate was added to the solution to precipitate the iodine as AgI, which was separated via filtration. The filtrate was analyzed for ${ }^{129} \mathrm{I} \&{ }^{125}$ I content using low energy photon/x-ray, thin-windowed, semi-planar high purity germanium spectrometers. Elemental iodine yields were measured by neutron activation analysis, and were used to 
SRNL-STI-2011-00331

Revision 0

correct the ${ }^{129} \mathrm{I} \&{ }^{125}$ I results for each aliquot for any iodine losses incurred during the radiochemical separation. The mineral products analyzed for iodide isotopes were digested/leached in concentrated nitric acid in the presence of the KI tracer to track yields. All ${ }^{125} \mathrm{I}$ analyses for the granular product, monolith and mass balance matrices were decay-corrected $\left(t_{1 / 2}=60.14\right.$ days) to the same analyses time of the original feed supernate.

For ${ }^{137} \mathrm{Cs}$, aliquots of sample were analyzed by coaxial high purity germanium gamma-ray spectrophotometers to measure ${ }^{137} \mathrm{Cs}$. The peroxide fusion preparations were used to prepare aliquots for ${ }^{137} \mathrm{Cs}$ analysis from dissolved mineral product.

\subsection{Preparation of WTP-SW Simulants}

\subsubsection{Non-Radioactive Simulant}

The non-radioactive simulant was prepared from a spreadsheet recipe received from TTT vial email transmission. The simulant was comprised of a concentrate without heavy metals and a separate heavy metals solution. Sodium phosphate was added to the simulant concentrate before subsequent blending with the heavy metals solution. Makeup water was then added to target a final volume. This constituted the WTP-SW non-radioactive simulant. To prepare feed for the BSR, the Sagger XX ${ }^{\circledR}$ and OptiKasT ${ }^{\circledR}$ clays were mixed into the non-radioactive simulant to form a slurry. The target WTP-SW simulant and resulting post-clay addition feed slurry are shown in Table 5 are derived from previous ESTD FBSR testing that was performed at HRI in 2008 [4]. Previous ESTD FBSR testing used spikes up to 10-1000X amounts of various RCRA metals and radionuclide surrogates. Some of those RCRA/UTS metals were added to the HRI ESTD FBSR testing even though they were not projected to be in the WTP-SW. It should be noted that per agreement with TTT, SRNL did not add the simulant chemicals for the RCRA/UTS metals Ba, Cd, Tl, Se and Sb shown in grey-shading in Table 5. These are the RCRA/UTS metals that have no basis for being in actual future WTP-SW feeds. 
SRNL-STI-2011-00331

Revision 0

Table 5. Target Composition of WTP-SW Simulant

\begin{tabular}{|c|c|c|}
\hline Component ${ }^{*}$ & $\begin{array}{c}\text { WTP-SW } \\
\text { Target } \\
\text { Component } \\
\text { Concentration } \\
\text { [g/L] }\end{array}$ & $\begin{array}{c}\text { WTP-SW } \\
\text { Target } \\
\text { Component } \\
\text { Concentration } \\
\text { with } 307 \text { g } \\
\text { clay/L }[\mathrm{g} / \mathrm{L}]\end{array}$ \\
\hline $\mathrm{Ag}$ & 0.092 & 0.083 \\
\hline $\mathrm{Al}$ & 14.782 & 61.951 \\
\hline As & 0.008 & 0.007 \\
\hline $\mathrm{B}$ & 1.432 & 1.284 \\
\hline $\mathrm{Ba}$ & 0.003 & 0.003 \\
\hline $\mathrm{Ca}$ & (not added) & 0.147 \\
\hline $\mathrm{Cd}$ & 0.098 & 0.088 \\
\hline $\mathrm{Cl}$ & 3.758 & 3.37 \\
\hline $\mathrm{CO}_{3}$ & 12.012 & 10.773 \\
\hline $\mathrm{Cr}$ & 0.315 & 0.282 \\
\hline $\mathrm{Cs}$ & 1.952 & 1.751 \\
\hline $\mathrm{F}$ & 4.155 & 3.727 \\
\hline $\mathrm{Fe}$ & (not added) & 1.261 \\
\hline I & 0.1 & 0.09 \\
\hline $\mathrm{K}$ & 0.409 & 0.492 \\
\hline $\mathrm{Mg}$ & (not added) & 0.134 \\
\hline $\mathrm{Na}$ & 61.334 & 55.715 \\
\hline $\mathrm{NH}_{4}$ & 5.272 & 4.728 \\
\hline $\mathrm{Ni}$ & 0.269 & 0.241 \\
\hline $\mathrm{NO}_{2}$ & 1.675 & 1.502 \\
\hline $\mathrm{NO}_{3}$ & 123.447 & 110.716 \\
\hline $\mathrm{OH}$ & 26.593 & 23.85 \\
\hline $\mathrm{Pb}$ & 0.272 & 0.244 \\
\hline $\mathrm{PO}_{4}$ & 0.699 & 0.755 \\
\hline $\mathrm{Re}$ & 0.211 & 0.189 \\
\hline $\mathrm{Sb}$ & 0.195 & 0.175 \\
\hline $\mathrm{Se}$ & 0.195 & 0.175 \\
\hline $\mathrm{Si}$ & 0.506 & 61.429 \\
\hline $\mathrm{SO}_{4}$ & 0.525 & 0.471 \\
\hline $\mathrm{Ti}$ & (not added) & 1.884 \\
\hline $\mathrm{Tl}$ & 0.195 & 0.175 \\
\hline $\mathrm{Zn}$ & 0.477 & 0.428 \\
\hline
\end{tabular}

* Resource Conservation and Recovery Act (RCRA) and Universal Treatment Standards (UTS) metals (Sb, As, Ag, $\mathrm{Cd}, \mathrm{Ba}$, and $\mathrm{Tl}$ ) and radionuclide surrogates (Re, I, Cs) were added at 10-1000X in ESTD FBSR testing. RCRA and UTS metals Ba, Cd, Tl, Se and Sb were not used in this Module A BSR study.

A subsample of the WTP-SW simulant feed slurry was analyzed by drying the slurry and dissolving the dried solids (by both peroxide fusion and lithium tetraborate) with subsequent cation and anion analyses. Table 6 shows the analyzed data from the simulant slurry vs. the ESTD ' $\mathrm{g} / \mathrm{L}$ ' WTP-SW target values and the drying data at the bottom of Table 6 . The elements Al through Zn were analyzed by ICP-ES, the elements Cs through I were analyzed by ICP-MS and the remaining anions by IC-anions. There is good agreement to within $\pm 10 \%$ on comparison of the major Al, Na and Si species with target. The WTP-SW feed slurry contained $\sim 38 \mathrm{wt} \%$ total solids. 
SRNL-STI-2011-00331

Revision 0

Table 6. WTP SW Simulant Slurry Analysis

\begin{tabular}{|c|c|c|c|c|c|c|}
\hline & \multicolumn{4}{|c|}{ BSR Simulant } & \multirow{2}{*}{$\begin{array}{c}\text { ESTD } \\
\text { g/L }\end{array}$} & \multirow{2}{*}{$\begin{array}{c}\text { BSR/ } \\
\text { ESTD }\end{array}$} \\
\hline & mg/kg dry & mg/kg wet & $\mathrm{mg} / \mathrm{L}$ & $g / L$ & & \\
\hline Al & 114500.0 & 44106.4 & 58661.5 & 58.7 & 62.0 & 0.9 \\
\hline As & $(<) 100.0$ & 38.5 & 51.2 & 0.1 & 0.0 & 7.3 \\
\hline B & 3965.0 & 1527.4 & 2031.4 & 2.0 & 1.3 & 1.6 \\
\hline $\mathbf{C a}$ & 735.0 & 283.0 & 376.4 & 0.4 & 0.1 & 2.6 \\
\hline $\mathrm{Cr}$ & 565.0 & 217.7 & 289.5 & 0.3 & 0.3 & 1.0 \\
\hline $\mathbf{F e}$ & 2590.0 & 998.2 & 1327.5 & 1.3 & 1.3 & 1.1 \\
\hline $\mathbf{K}$ & 2935.0 & 1130.6 & 1503.7 & 1.5 & 0.5 & 3.1 \\
\hline Mg & 400.0 & 154.0 & 204.9 & 0.2 & 0.1 & 1.5 \\
\hline $\mathbf{N a}$ & 94450.0 & 36384.6 & 48391.5 & 48.4 & 55.7 & 0.9 \\
\hline $\mathrm{Ni}$ & $(<) 100.0$ & 38.5 & 51.2 & 0.1 & 0.2 & 0.2 \\
\hline $\mathbf{P b}$ & 100.0 & 38.5 & 51.2 & 0.1 & 0.2 & 0.2 \\
\hline $\mathbf{S i}$ & 132000.0 & 50848.8 & 67628.9 & 67.6 & 61.4 & 1.1 \\
\hline $\mathbf{T i}$ & 6050.0 & 2330.6 & 3099.7 & 3.1 & 1.9 & 1.6 \\
\hline $\mathbf{Z n}$ & 875.0 & 337.1 & 448.3 & 0.4 & 0.4 & 1.0 \\
\hline Cs & 3635.0 & 1400.1 & 1862.2 & 1.9 & 1.8 & 1.1 \\
\hline $\mathbf{R e}$ & 610.0 & 235.0 & 312.5 & 0.3 & 0.2 & 1.7 \\
\hline I & 267.5 & 103.1 & 137.1 & 0.1 & 0.1 & 1.5 \\
\hline $\mathbf{F}$ & 7390.0 & 2847.1 & 3786.6 & 3.8 & 3.7 & 1.0 \\
\hline Cl & 5745.0 & 2213.4 & 2943.8 & 2.9 & 3.4 & 0.9 \\
\hline $\mathrm{NO}_{2}$ & 3450.0 & 1328.8 & 1767.3 & 1.8 & 1.5 & 1.2 \\
\hline $\mathrm{NO}_{3}$ & 160500.0 & 61837.0 & 82243.2 & 82.2 & 110.7 & 0.7 \\
\hline $\mathrm{SO}_{4}$ & 1175.0 & 452.5 & 601.9 & 0.6 & 0.5 & 1.3 \\
\hline $\mathrm{PO}_{4}$ & $(<) 500.0$ & 192.6 & 256.2 & 0.3 & 0.8 & 0.3 \\
\hline Total Solids & Wet Wt. & Dry Wt. & - & -- & -- & - \\
\hline $38.7 \%$ & 6.178 & 2.393 & -- & -- & -- & - \\
\hline $38.3 \%$ & 5.857 & 2.244 & -- & -- & -- & - \\
\hline
\end{tabular}

\subsubsection{Radioactive Simulant}

The radioactive feed for the BSR was prepared from an SRS DWPF Off-gas Condensate Tank (OGCT) solution. The 20-Liter sample was transferred to SRNL from the DWPF in a total of 20 individual 1-liter bottles. The individual 1-liter bottles were placed in the SRNL SC where they were remotely opened and processed through a 0.5 micron filter prior to compositing and analyses. Some trace insoluble solids were filtered out of the DWPF OGCT samples. These solids that initially appeared as trace solids around the bottom of the various as-received 1-liter bottles (and later filtered out during compositing) were not used for further testing due to the suspect presence of transuranic (TRU) components from processing of HLW through the DWPF melter, i.e., it was not desired to create a TRU waste form in subsequent BSR processing of this DWPF OGCT feedstream. Photographs of an individual DWPF OGCT 1-liter bottle before filtration and the final two 10-L carboys after filtration and compositing are shown in Figure 1. 


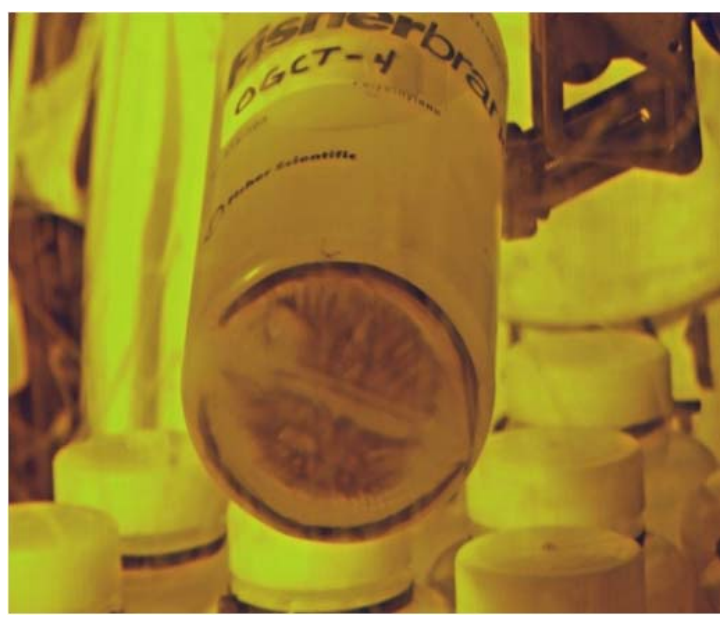

A 1-Liter DWPF OGCT Bottle with Trace Solids

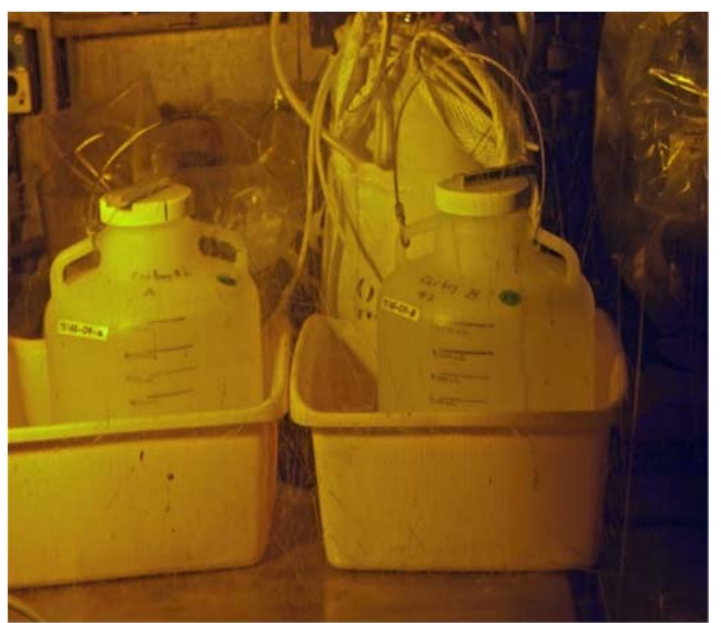

Two final 10-L Carbouys of the filtered and composited DWPF OGCT Sample

Figure 1. Photographs of DWPF OGCT in Shielded Cells

Analyses of the 20-L composite filtrate DWPF OGCT were performed to determine the general metals, anions and radionuclide composition. A nominal 20X concentration factor was applied to estimate the levels of these constituents in a $20 \mathrm{X}$ concentrated sample, i.e., to remove $19 \mathrm{~L}$ of water from the 20 -Liter condensate sample leaving a 1-liter concentrate. The calculated $20 \mathrm{X}$ solution concentration was then compared to the WTP-SW simulant target, and shim chemicals were added to the 20 Liter sample before concentration. The filtered and composited 20-Liter DWPF OGCT analysis is shown in Table 7. The main constituents present derive from melter operations from DWPF to make HLW glass. Thus, several glass and sludge elements are at detectable levels including Al, B, Ca, Na and Si. Mercury is also present in the condensate as a volatile component in the melter operations. The main radionuclides present in the condensate are ${ }^{137} \mathrm{Cs}$ and likely ${ }^{90} \mathrm{Sr}$. Although no radiochemical analyses for ${ }^{90} \mathrm{Sr}$ was performed, the presence of detectable $\mathrm{Sr}$ in the ICPES and the high level of total beta activity suggests presence of ${ }^{90} \mathrm{Sr}$. 
Table 7. DWPF OGCT Chemical Composition Analysis

\begin{tabular}{|c|c|c|c|c|c|c|c|c|c|c|c|c|c|}
\hline Cations & & $\begin{array}{c}\text { Avg. } \\
(\mathrm{mg} / \mathrm{L})\end{array}$ & St.Dev. & $\%$ RSD & & $\begin{array}{c}\text { x 20 } \\
(\mathrm{mg} / \mathrm{L})\end{array}$ & Anions & & $\begin{array}{c}\text { Avg. } \\
(\mathbf{m g} / \mathbf{L})\end{array}$ & St.Dev. & \%RSD & & $\begin{array}{c}\mathbf{x ~ 2 0} \\
(\mathrm{mg} / \mathrm{L})\end{array}$ \\
\hline $\mathrm{Ag}$ & $<$ & 0.031 & NA & $\mathrm{NA}$ & $<$ & 0.6 & $\bar{F}$ & & 4.0 & 0.0 & 0.0 & & 80.0 \\
\hline $\mathrm{Al}$ & & 6.98 & 0.2 & 2.9 & & 139.5 & $\mathrm{Cl}$ & & 5.0 & 0.0 & 0.0 & & 100.0 \\
\hline As & $<$ & 0.03 & NA & $\overline{\mathrm{NA}}$ & $<$ & 0.6 & $\mathrm{NO} 2$ & & 9.0 & 0.0 & 0.0 & & 180.0 \\
\hline B & & 6.78 & 0.2 & 2.7 & & 135.6 & $\mathrm{NO} 3$ & & 198.0 & 7.1 & 3.6 & & 3960.0 \\
\hline $\mathrm{Ba}$ & & 0.09 & 0.0 & 4.0 & & 1.7 & $\mathrm{PO} 4$ & $<$ & 5.0 & NA & NA & $<$ & 100.0 \\
\hline $\mathrm{Be}$ & $<$ & 0.02 & NA & $\mathrm{NA}$ & $<$ & 0.4 & $(\mathrm{P})$ & $<$ & 1.7 & NA & NA & $<$ & 33.0 \\
\hline $\mathrm{Ca}$ & & 2.23 & 0.1 & 2.5 & & 44.6 & $\mathrm{SO} 4$ & & 11.0 & 0.0 & 0.0 & & 220.0 \\
\hline $\mathrm{Cd}$ & & 0.47 & 0.0 & 3.0 & & 9.3 & (S) & & 3.7 & 0.0 & 0.0 & & 73.5 \\
\hline $\mathrm{Ce}$ & $<$ & 0.17 & NA & NA & $<$ & 3.3 & Radionuclides & & $\mathrm{dpm} / \mathrm{mL}$ & & & & dpm/mL \\
\hline $\mathrm{Cr}$ & & 0.05 & 0.0 & 4.7 & & 1.0 & ${ }^{60} \mathrm{Co}$ & & $2.2 \mathrm{E}+02$ & NA & NA & & $4.3 \mathrm{E}+03$ \\
\hline $\mathrm{Cu}$ & $<$ & 0.05 & NA & $\mathrm{NA}$ & $<$ & 1.1 & ${ }^{137} \mathrm{Cs}$ & & $9.5 \mathrm{E}+05$ & NA & NA & & $1.9 \mathrm{E}+07$ \\
\hline $\mathrm{Fe}$ & & 0.02 & 0.0 & 4.8 & & 0.5 & ${ }^{154} \mathrm{Eu}$ & & $5.7 \mathrm{E}+03$ & NA & NA & & $1.1 \mathrm{E}+05$ \\
\hline $\mathrm{Gd}$ & & 0.09 & 0.0 & 2.4 & & 1.9 & ${ }^{241} \mathrm{Am}$ & & $5.9 \mathrm{E}+03$ & NA & NA & & $1.2 \mathrm{E}+05$ \\
\hline $\mathrm{Hg}$ & & 25.10 & NA & $\overline{\mathrm{NA}}$ & & 502.0 & ${ }^{99} \mathrm{Tc}$ & & $1.5 \mathrm{E}+03$ & NA & NA & & $3.0 \mathrm{E}+04$ \\
\hline $\mathrm{K}$ & $<$ & 0.37 & NA & NA & $<$ & 7.4 & ${ }^{129} \mathrm{I}$ & & $3.0 \mathrm{E}+01$ & NA & NA & & $6.1 \mathrm{E}+02$ \\
\hline $\mathrm{La}$ & & 0.06 & 0.0 & 3.8 & & 1.2 & ALPHA COUNT & $<$ & $5.6 \mathrm{E}+04$ & NA & NA & $<$ & $1.1 \mathrm{E}+06$ \\
\hline $\mathrm{Li}$ & & 1.54 & 0.0 & 2.8 & & 30.8 & BETA COUNT & & $1.2 \mathrm{E}+07$ & NA & NA & & $2.3 \mathrm{E}+08$ \\
\hline $\mathrm{Mg}$ & & 1.07 & 0.0 & 2.6 & & 21.4 & & & & & & & \\
\hline $\mathrm{Mn}$ & & 1.46 & 0.0 & 2.9 & & 29.2 & & & & & & & \\
\hline Mo & $<$ & 0.05 & NA & NA & $<$ & 1.0 & & & & & & & \\
\hline $\mathrm{Na}$ & & 45.50 & 1.3 & 2.8 & & 910.0 & & & & & & & \\
\hline $\mathrm{Ni}$ & & 0.30 & 0.0 & 2.4 & & 6.0 & & & & & & & \\
\hline $\mathrm{P}$ & $<$ & 0.15 & NA & NA & $<$ & 3.0 & & & & & & & \\
\hline $\mathrm{Pb}$ & $<$ & 0.08 & NA & NA & $<$ & 1.5 & & & & & & & \\
\hline $\begin{array}{l}S \\
\end{array}$ & & 3.20 & 0.6 & 18.4 & & 63.9 & & & & & & & \\
\hline $\mathrm{Se}$ & $<$ & 0.06 & NA & NA & $<$ & 1.1 & & & & & & & \\
\hline $\mathrm{Sb}$ & $<$ & 0.08 & NA & NA & $<$ & 1.5 & & & & & & & \\
\hline $\mathrm{Si}$ & & 14.25 & 0.5 & 3.5 & & 285.0 & & & & & & & \\
\hline $\mathrm{Sn}$ & $<$ & 0.04 & NA & $\mathrm{NA}$ & $<$ & 0.7 & & & & & & & \\
\hline $\mathrm{Sr}$ & & 0.06 & 0.0 & 2.5 & & 1.2 & & & & & & & \\
\hline $\mathrm{Ti}$ & $<$ & 0.02 & NA & NA & $<$ & 0.5 & & & & & & & \\
\hline $\mathrm{U}$ & & 7.35 & 0.3 & 3.6 & & 146.9 & & & & & & & \\
\hline $\mathrm{V}$ & $<$ & 0.07 & NA & NA & $<$ & 1.3 & & & & & & & \\
\hline $\mathrm{Zn}$ & & 0.10 & 0.0 & 1.9 & & 2.0 & & & & & & & \\
\hline $\mathrm{Zr}$ & $<$ & 0.04 & NA & NA & $<$ & 0.9 & & & & & & & \\
\hline
\end{tabular}


To concentrate the 20-L DWPF OGCT to less than 1 liter, an evaporation unit was fabricated. The unit is shown in Figure 2. The apparatus contained a feed pump and level indicator device to automatically meter in the feed as condensate was removed from the system. Figure 2 shows the central evaporator pot with white insulating wrap and the condenser coming off the top left.

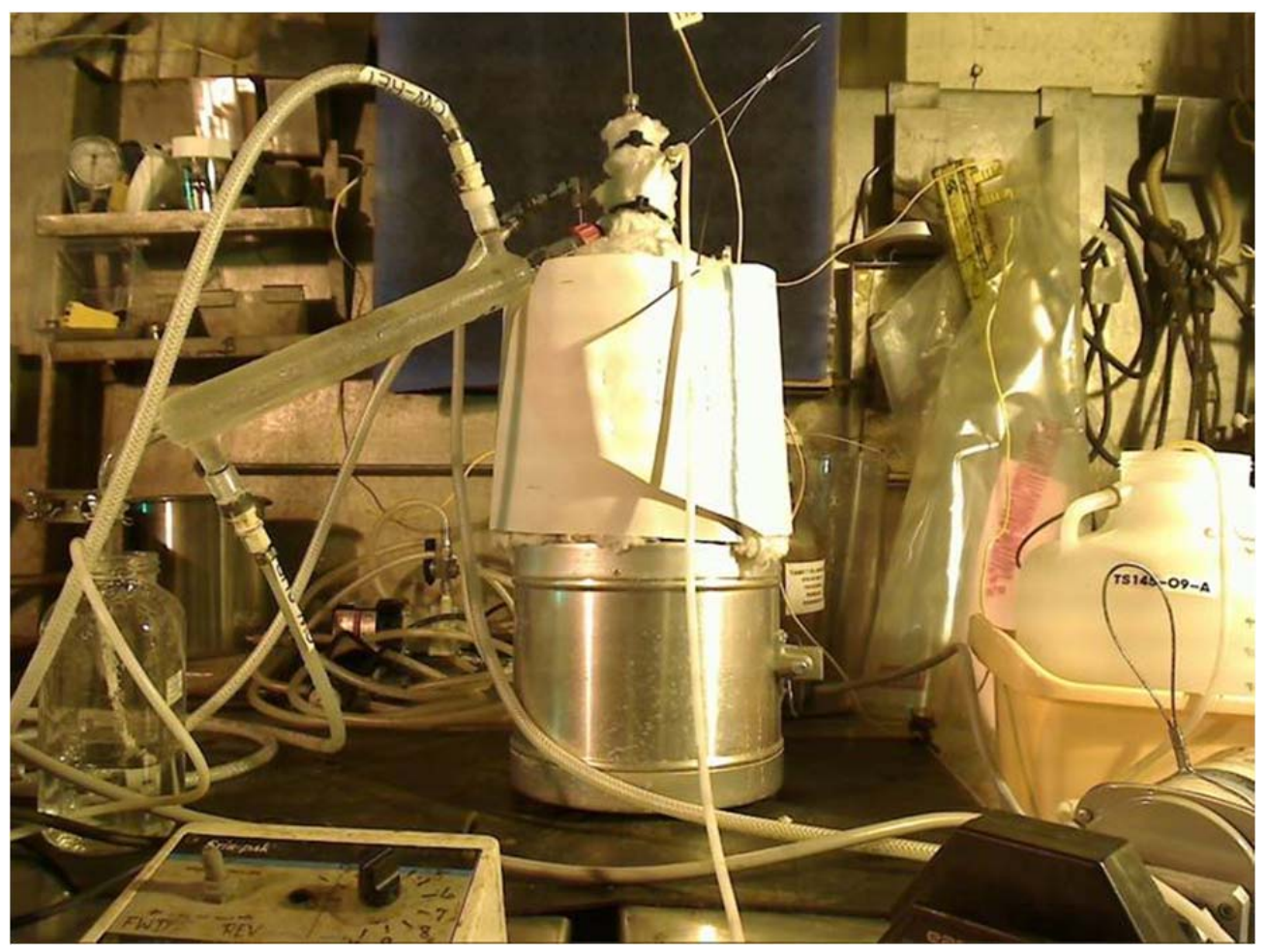

Figure 2. Photographs of DWPF OGCT Evaporator in the Shielded Cells

The shimmed 20 liters of DWPF OGCT were concentrated to less than 1 liter. All 20 Liters were fed to the evaporator over a two-day evaporation campaign on 12/7/09 and 12/10/09, and the OGCT was concentrated to less than 1 Liter to allow for final shim chemicals and radionuclides to be added. After the $\sim 500 \mathrm{~mL}$ concentrated sample was transferred to a poly bottle, some insoluble solids were noticed in the bottom of the evaporator. These solids were slurried into the concentrated solution using some of the condensate. Figure 3 shows the initial concentrated solution and the insoluble solids remaining in the bottom of the evaporator. Figure 4 shows the final $\sim 600 \mathrm{~mL}$ of concentrated sample before and after settling of the insoluble solids formed during evaporation. All other condensate collected during evaporation was disposed to the SRNL High Activity Drain system. 


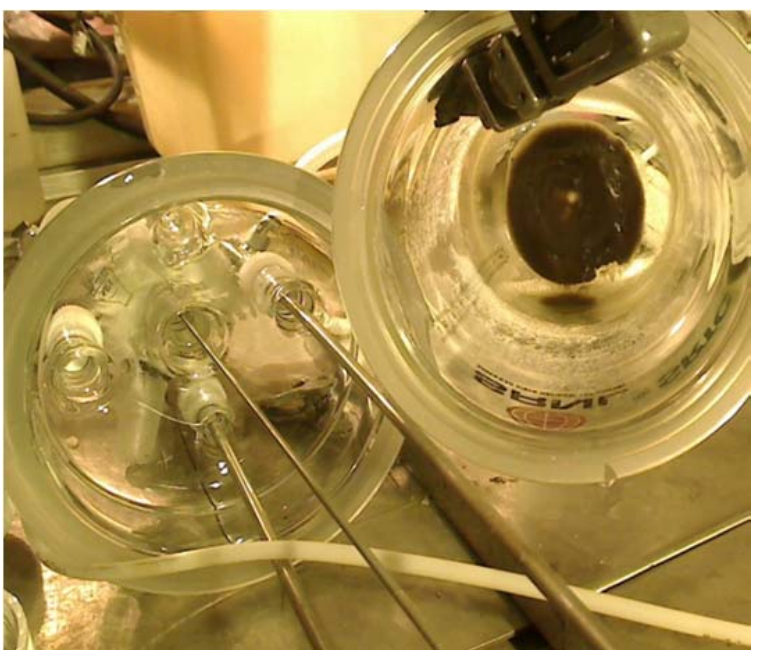

Settled insoluble solids remaining after transfer of concentrated OGCT

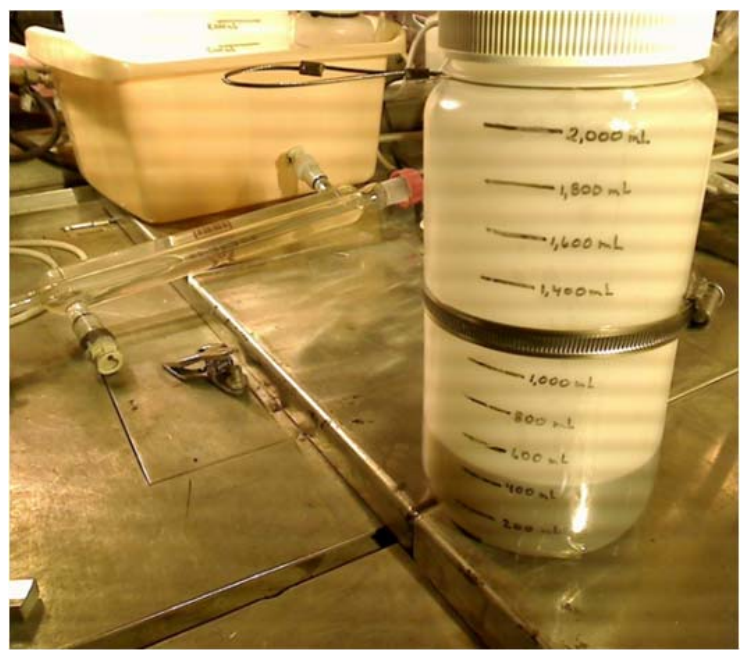

Transferred concentrated OGCT from the evaporator

Figure 3. Photographs of DWPF OGCT in Shielded Cells After Concentration

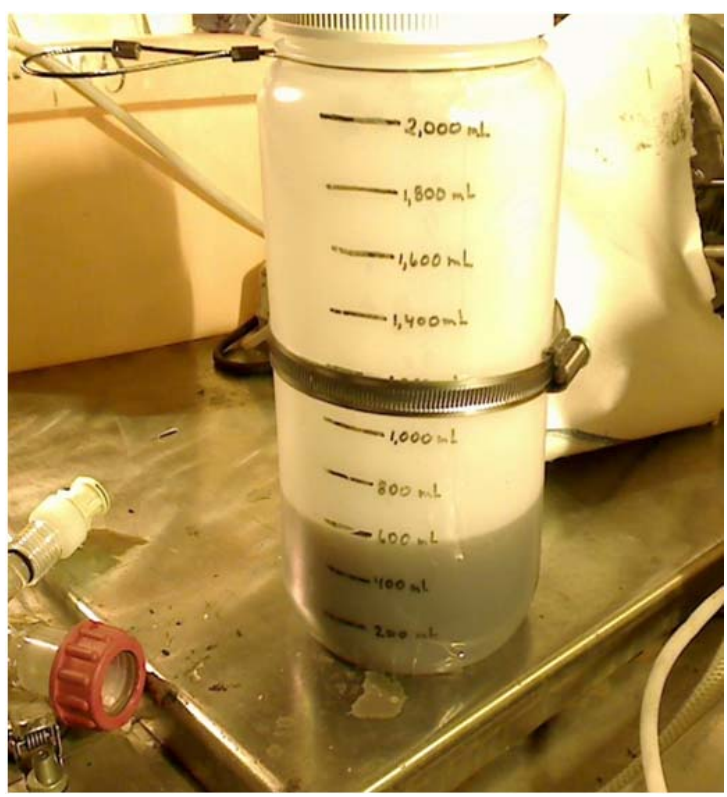

Concentrated sample after transfer of insoluble solids from evaporator

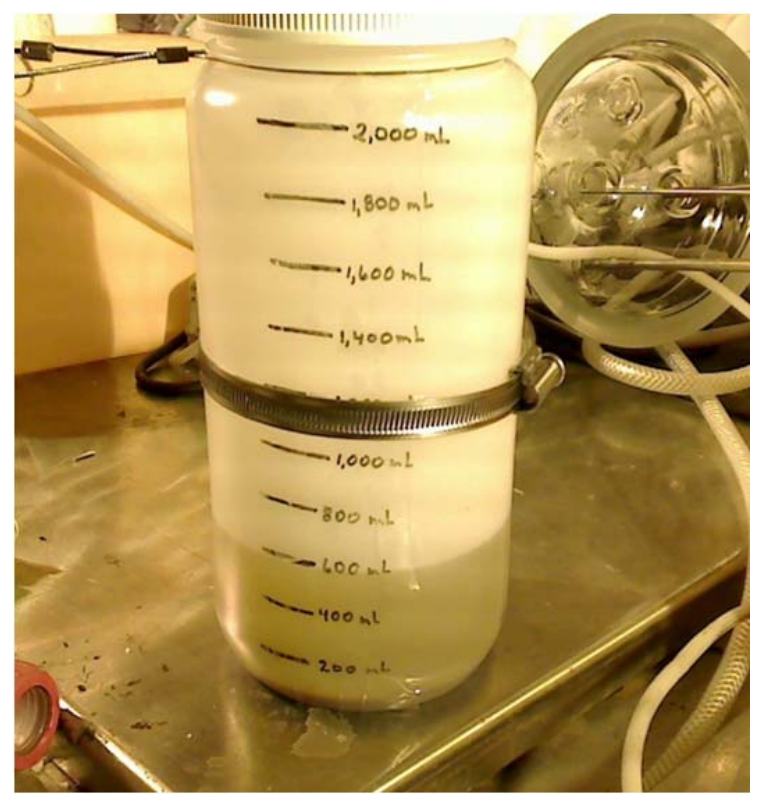

Settled concentrated sample with insoluble solids (after $\sim 0.5$ hour).

Figure 4. Photographs of DWPF OGCT in Shielded Cells After Final Dilution

Insoluble solids formed during evaporation were sub-sampled to determine observable crystalline phases present by XRD.

Figure 5 shows the XRD spectrum of the concentrate solids that are comprised mainly of a $\mathrm{NaF}$ crystalline villiaumite species, with other trace components of sodium salts of carbonate, aluminosilicate, phosphate and nitrate. No further characterization efforts were performed to determine the detailed chemical content of these insoluble solids. 


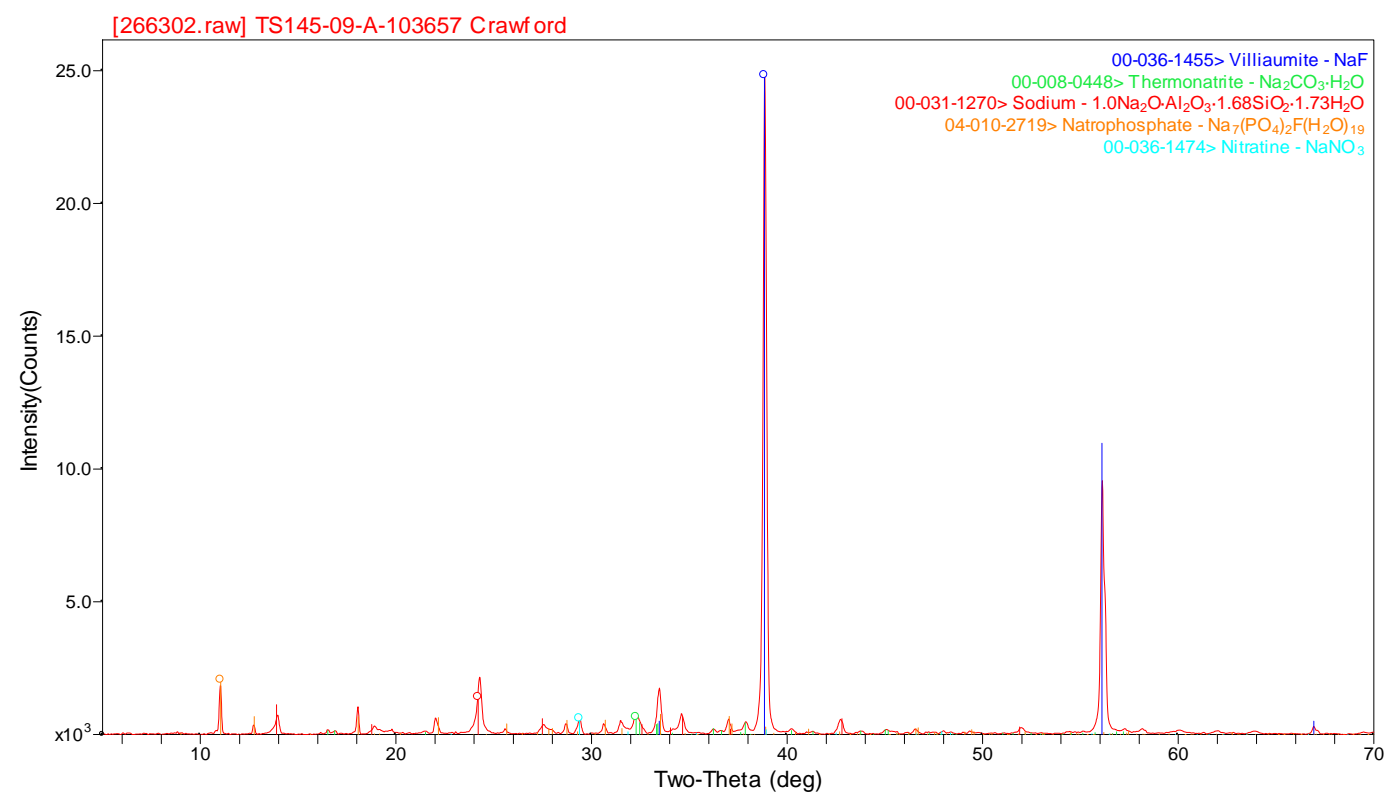

Figure 5. XRD Spectra of Insoluble Solids Formed During DWPF OGCT Evaporation

The $\sim 600 \mathrm{~mL}$ of concentrated DWPF OGCT, shimmed to match WTP-SW, was stored in the SRNL SC from January 2010 through August 2010. In September 2010, the sample was prepared for radioactive BSR runs by adding $\mathrm{Al}$ and $\mathrm{Re}$ and radionuclides $\left({ }^{99} \mathrm{Tc},{ }^{129} \mathrm{I}\right.$ and $\left.{ }^{125} \mathrm{I}\right)$.

The estimated concentrations from the 20X concentration column above were compared to the WTP-SW simulant target to determine what chemical shims needed to be added to the DWPF OGCT before concentration. Table 8 below shows the chemical shims and their target masses added to the 20-Liter sample. 
SRNL-STI-2011-00331

Revision 0

Table 8. Shim Chemicals Added to the DWPF OGCT before Concentration

\begin{tabular}{|l|c|}
\hline \multicolumn{1}{|c|}{ Chemical } & Amount $(\mathrm{g})$ \\
\hline Sodium Silicate Solution & 2.863 \\
\hline $\mathrm{NH}_{4} \mathrm{NO}_{3}$ & 21.412 \\
\hline $\mathrm{Na}_{2} \mathrm{~B}_{4} \mathrm{O}_{7} \cdot 10 \mathrm{H}_{2} \mathrm{O}$ & 15.762 \\
\hline $\mathrm{KNO}_{3}$ & 1.424 \\
\hline $\mathrm{NaOH}$ & 84.712 \\
\hline $\mathrm{Na}_{2} \mathrm{CO}_{3}$ & 28.425 \\
\hline $\mathrm{Na}_{2} \mathrm{SO}_{4}$ & 0.722 \\
\hline $\mathrm{NaCl}$ & 8.158 \\
\hline $\mathrm{NaF}$ & 12.383 \\
\hline $\mathrm{KI}$ & 0.007 \\
\hline $\mathrm{NaNO}_{2}$ & 3.148 \\
\hline $\mathrm{Al}_{(}\left(\mathrm{NO}_{3}\right)_{3} \bullet 9 \mathrm{H}_{2} \mathrm{O}(60 \mathrm{wt} \%$ sol'n, $\boldsymbol{\rho}=\mathbf{1 . 3 2 6})$ & 2.182 \\
\hline $\mathrm{AgNO}_{3}$ & 0.0002 \\
\hline $\mathrm{Pb}_{2}\left(\mathrm{NO}_{3}\right)_{2}$ & 0.006 \\
\hline $\mathrm{Zn}_{2}\left(\mathrm{NO}_{3}\right)_{2}$ & 2.903 \\
\hline $\mathrm{As}_{2} \mathrm{O}_{3}$ & 0.008 \\
\hline $\mathrm{Na}_{2} \mathrm{Cr}_{2} \mathrm{O}_{7} 2 \mathrm{H}_{2} \mathrm{O}$ & 1.211 \\
\hline $\mathrm{Na}_{3} \mathrm{PO}_{4} \cdot 12 \mathrm{H}_{2} \mathrm{O}$ & 4.034 \\
\hline
\end{tabular}

After initial chemical shimming of the 20-Liter DWPF OGCT, and following concentration down to $600 \mathrm{~mL}$, additional chemicals were added to obtain the final 1-liter concentrate pre-clay radioactive sample. These final chemicals and the radionuclides are shown below in Table 9. The aluminum chemical is added to the WTP-SW feed to prevent formation of low-melting point glass compounds. Rhenium was added to the radioactive BSR feed to provide tieback data to the simulant BSR processing. There was sufficient radiocesium ${ }^{137} \mathrm{Cs}$ in the radioactive concentrate, and only the three radionuclides ${ }^{99} \mathrm{Tc},{ }^{129} \mathrm{I}$ and a short-lived ${ }^{125}$ I were added. This final solution was diluted to the 1-liter mark, mixed well and subsampled for analysis before clay additions prior to feeding through the BSR. Analysis of the pre-clay radioactive WTP-SW feed solution is shown in Table 10 below vs. the simulant targets. Analyzed values shown in Table 10 that are grey-shaded indicate species that were shimmed into the original DWPF OGCT.

Table 9. Additional Shim Chemicals and Radionuclides Added to DWPF OGCT Concentrate

\begin{tabular}{|l|c|}
\hline \multicolumn{1}{|c|}{ Chemical } & Amount (g) \\
\hline $\begin{array}{l}\mathrm{Al}\left(\mathrm{NO}_{3}\right)_{3} \cdot 9 \mathrm{H}_{2} \mathrm{O}(60 \\
\left.\mathrm{wt} \% \mathrm{sol}^{\prime} \mathrm{n}, \rho=1.326\right)\end{array}$ & 343.1 \\
\hline $\mathrm{NaReO}$ & \\
\hline${ }^{99} \mathrm{Tc}$ & 0.313 \\
\hline${ }^{129} \mathrm{I}$ & $138 \mu \mathrm{Ci}$ \\
\hline${ }^{125} \mathrm{I}$ & $50 \mu \mathrm{Ci}$ \\
\hline
\end{tabular}

A comparison of the non-radioactive WTP SW target compositions and the analyzed shimmed radioactive waste is given in Table 10. Note that the radioactive waste was spiked with Re as well as ${ }^{99} \mathrm{Tc}$ to determine whether Re is a good simulant for ${ }^{99} \mathrm{Tc}$ in these minerals as the oxyanion. ${ }^{\S}$ The DWPF recycle

\footnotetext{
$\S$ similar oxyanion size in the VII oxidation state, i.e. $1.702\left(\mathrm{TcO}_{4}{ }^{-}\right)$and $1.719\left(\mathrm{ReO}_{4}{ }^{-}\right)$
} 
had sufficient ${ }^{137} \mathrm{Cs}$; therefore it did not require additional shimming. Both ${ }^{125} \mathrm{I}$ and ${ }^{129} \mathrm{I}$ were added to the radioactive sample in order to detect these elements radiometrically during leach testing. Table 10 indicates that there is good agreement between the composition of the shimmed DWPF waste and the target WTP-SW waste. All shim species added are given in bold, italics, and shading in Table 10. Resource Conservation and Recovery Act (RCRA) metals such as Cr were added to the evaporated SRS melter recycle to match the WTP-SW target. RCRA metals (As and Ag) and radionuclide surrogates (Re, I) were doped in at $10-1000 \mathrm{X}$

Table 10. Chemical Composition of Radioactive Simulant A

\begin{tabular}{|c|c|c|c|}
\hline & & $\begin{array}{c}\text { Non-Radioactive } \\
\text { Recipe } \\
\text { (Module A SIM) }\end{array}$ & $\begin{array}{c}\text { Analyzed } \\
\text { Radioactive } \\
\text { (Module A RAD) }\end{array}$ \\
\hline Chemical Name & Element & \multicolumn{2}{|c|}{$\begin{array}{c}\text { Shimmed DWPF } \\
\text { Melter Recycle WTP-SW (mol/L) }\end{array}$} \\
\hline Aluminum & $\mathrm{Al}$ & 0.548 & 0.4596 \\
\hline Silver & $\mathrm{Ag}$ & 0.00086 & $<8.20 E-06$ \\
\hline Arsenic & As & 0.00010 & $8.09 E-05$ (calc) \\
\hline Boron & $\mathrm{B}$ & 0.132 & 0.16 \\
\hline Barium & $\mathrm{Ba}$ & Not added & $1.2 \mathrm{E}-05$ \\
\hline Calcium & $\mathrm{Ca}$ & --- & 0.00332 \\
\hline Cadmium & $\mathrm{Cd}$ & Not added & $6.01 \mathrm{E}-05$ \\
\hline Chromium & $\mathrm{Cr}$ & 0.00606 & 0.0067 \\
\hline \multirow{2}{*}{ Cesium } & ${ }^{133} \mathrm{Cs}$ & 0.01469 & --- \\
\hline & ${ }^{137} \mathrm{Cs}$ & -- & $7.52 \mathrm{E}-07$ \\
\hline Iron & $\mathrm{Fe}$ & --- & 0.0001 \\
\hline Mercury & $\mathrm{Hg}$ & --- & --- \\
\hline Potassium & $\mathrm{K}$ & 0.010 & 0.0135 \\
\hline Lanthanum & $\mathrm{La}$ & --- & $4.5 \mathrm{E}-06$ \\
\hline Lithium & $\mathrm{Li}$ & --- & 0.0036 \\
\hline Magnesium & $\mathrm{Mg}$ & --- & 0.0010 \\
\hline Manganese & $\mathrm{Mn}$ & --- & 0.0004 \\
\hline Sodium & $\mathrm{Na}$ & 2.668 & 2.5490 \\
\hline Nickel & $\mathrm{Ni}$ & 0.00458 & $9.37 \mathrm{E}-05$ \\
\hline Phosphorus & $\mathrm{P}$ & 0.007 & 0.0096 \\
\hline Lead & $\mathrm{Pb}$ & 0.00131 & $<9.27 E-05$ \\
\hline Rhenium & $\mathrm{Re}$ & 0.00113 & 0.00115 (calc) \\
\hline Antimony & $\mathrm{Sb}$ & Not added & $<2.66 \mathrm{E}-05$ \\
\hline Selenium & $\mathrm{Se}$ & Not added & --- \\
\hline Silicon & $\mathrm{Si}$ & 0.018 & 0.0726 \\
\hline Strontium & $\mathrm{Sr}$ & --- & $1.35 \mathrm{E}-05$ \\
\hline Technetium & ${ }^{99} \mathrm{Tc}$ & --- & $8.30 E-05$ \\
\hline Thorium & $\mathrm{Th}$ & --- & $<1.81 \mathrm{E}-05$ \\
\hline Titanium & $\mathrm{Ti}$ & --- & $2.46 \mathrm{E}-05$ \\
\hline Uranium & $\mathrm{U}$ & --- & 0.0005 \\
\hline Zinc & $\mathrm{Zn}$ & 0.00729 & 0.0076 \\
\hline Chloride & $\mathrm{Cl}$ & 0.106 & 0.094 \\
\hline Fluoride & $\mathrm{F}$ & 0.219 & 0.180 \\
\hline Iodide & ${ }^{129} \mathrm{I}$ & & $5.25 E-05$ \\
\hline Iodide & ${ }^{125} \mathrm{I}$ & & $5.32 E-12$ \\
\hline Iodide & ${ }^{127} \mathrm{I}$ & 0.001 & $4.22 E-05$ \\
\hline Sulfate & $\mathrm{SO}_{4}$ & 0.005 & 0.0066 \\
\hline Carbonate & $\mathrm{CO}_{3}$ & 0.200 & --- \\
\hline Hydroxide & $\mathrm{OH}$ & 1.564 & --- \\
\hline Nitrate & $\mathrm{NO}_{3}$ & 1.991 & 2.060 \\
\hline Nitrite & $\mathrm{NO}_{2}$ & 0.036 & 0.003 \\
\hline
\end{tabular}




\subsubsection{Use of MINCALC ${ }^{T M}$ to Control Mineralogy}

A process control strategy for the FBSR mineralizing process was developed by SRNL in 2004 and is based on composition control in the NAS oxide system (Figure 6). The process control strategy is known as MINCALC ${ }^{\text {TM }}$ and has been used to control the SAIC-STAR campaigns in 2004, the TTT/HRI ESTD campaigns in 2008 and the BSR campaigns (2004 and 20010-2011).

MINCALC ${ }^{\text {TM }}$ controls the simulant or radioactive A (WTP-SW) FBSR product (yellow shape) in the region of nepheline/sodalite formation (region in Figure 6 where the blue rectangle for AN-107 lies). MINCALC ${ }^{\mathrm{TM}}$ can also be used to calculate the theoretical weight percent of each of the mineral phases. All campaigns are run with excess clay and hence excess $\mathrm{Al}_{2} \mathrm{O}_{3}$ and $\mathrm{SiO}_{2}$ appear in the species predictions (Table 11) and in the products. The sum of all predicted phases has not been normalized to $100 \%$, so sums shown at the bottom of Table 11 do not add to 100 .

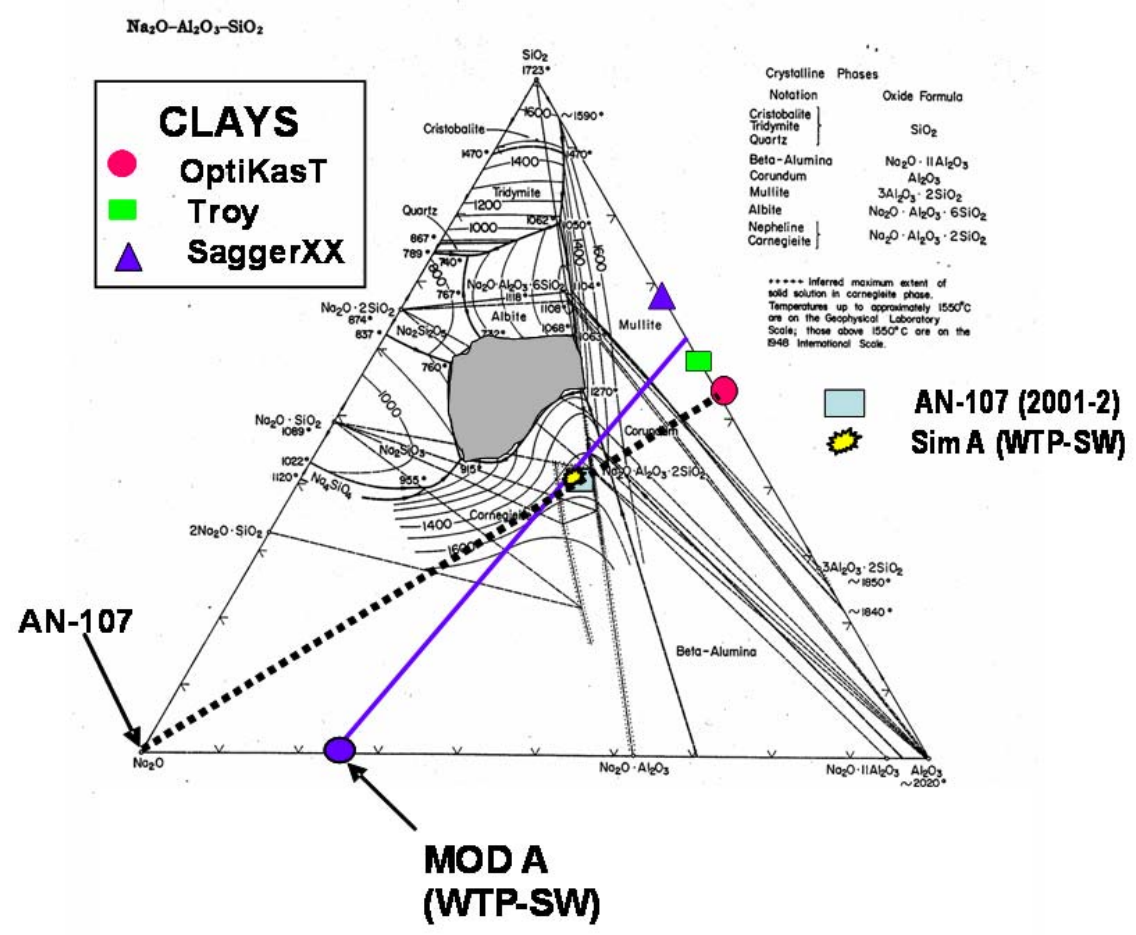

Figure 6. $\mathrm{Na}_{2} \mathrm{O}-\mathrm{Al}_{2} \mathrm{O}_{3}-\mathrm{SiO}_{2}$ (NAS) Ternary showing the composition of the WTP-SW waste composition along the base of the triangle $\left(\mathrm{Na}_{2} \mathrm{O}-\mathrm{Al}_{2} \mathrm{O}_{3}\right.$ binary) and the position of the potential clay additives on the $\mathrm{Al}_{2} \mathrm{O}_{3}-\mathrm{SiO}_{2}$ binary 
Table 11. MINCALC ${ }^{\mathrm{TM}}$ PREDICTED PHASES

\begin{tabular}{|l|l|c|c|}
\hline Mineral Component & \multicolumn{1}{|c|}{$\begin{array}{c}\text { Chemical } \\
\text { Component }\end{array}$} & $\begin{array}{c}\text { NON-RADIOACTIVE } \\
\text { RADIOACTIVE }\end{array}$ & $\begin{array}{c}\text { WTP-SW } \\
\text { (MOD A SIM) } \\
\text { (Wt\%) }\end{array}$ \\
\hline Na Nepheline & $\mathrm{Na}_{2} \mathrm{Al}_{2} \mathrm{Si}_{2} \mathrm{O}_{8}$ & $\begin{array}{c}\text { WTP-SW } \\
\text { (MOD A RAD) } \\
\text { (Wt\%) }\end{array}$ \\
\hline K Nepheline & $\mathrm{K}_{0.5} \mathrm{Na}_{1.5} \mathrm{Al}_{2} \mathrm{Si}_{2} \mathrm{O}_{8}$ or $\mathrm{K}_{2} \mathrm{Na}_{6} \mathrm{Al}_{8} \mathrm{Si}_{8} \mathrm{O}_{32}$ & 27.42 & 32.58 \\
\hline Cl Sodalite & $\mathrm{Na}_{8} \mathrm{Al}_{6} \mathrm{Si}_{6} \mathrm{O}_{24}\left(\mathrm{Cl}_{2}\right)$ & 4.94 & 5.51 \\
\hline F Sodalite & $\mathrm{Na}_{8} \mathrm{Al}_{6} \mathrm{Si}_{6} \mathrm{O}_{24}\left(\mathrm{~F}_{2}\right)$ & 12.96 & 11.88 \\
\hline I Sodalite & $\mathrm{Na}_{8} \mathrm{Al}_{6} \mathrm{Si}_{6} \mathrm{O}_{24}\left(\mathrm{I}_{2}\right)$ & 25.88 & 21.84 \\
\hline Nosean & $\mathrm{Na}_{8} \mathrm{Al}_{6} \mathrm{Si}_{6} \mathrm{O}_{24}\left(\mathrm{SO}_{4}\right)$ & 6.01 & 5.51 \\
\hline Re Sodalite & $\mathrm{Na}_{8} \mathrm{Al}_{6} \mathrm{Si}_{6} \mathrm{O}_{24}\left(\mathrm{ReO}_{4}\right)_{2}$ & 1.25 & 1.70 \\
\hline Tc Sodalite & $\mathrm{Na}_{8} \mathrm{Al}_{6} \mathrm{Si}_{6} \mathrm{O}_{24}\left(\mathrm{TcO}_{4}\right)_{2}$ & 0.20 & 0.20 \\
\hline Free Silica & $\mathrm{SiO}_{2}$ & --- & 0.0133 \\
\hline Free Alumina & $\mathrm{Al}_{2} \mathrm{O}_{3}$ & 8.00 & 8.67 \\
\hline SUM & & 8.39 & 7.02 \\
\hline
\end{tabular}

Because this feed had a considerable amount of $\mathrm{Al}_{2} \mathrm{O}_{3}$ in it a mixture of two clays had to be used to drive the clay-waste mixture into the nepheline forming region of the NAS ternary shown in Figure 6.

Therefore, the "lever line" falls in between the two clays used, OptiKasT ${ }^{\circledR}$ and Sagger XX ${ }^{\circledR}$. Note that MINCALC ${ }^{\mathrm{TM}}$ predicts that high concentrations of halide sodalite will form to sequester the $\mathrm{Cl}$, $\mathrm{F}$, and I in the secondary waste and there is less of the sulfate host nosean as there is less sulfate in the secondary waste compared to the halides. There is still enough excess nepheline to form $\sim 30$ weight percent nepheline (Table 11).

MINCALC ${ }^{\text {TM }}$ was used to determine the amounts and type of clays to be mixed with each feed (see Table 12). In all campaigns, the clay was mixed with the salt waste in a large batch to accommodate all the expected runs.

Table 12. Clay Additives Determined from MINCALC ${ }^{\mathrm{TM}}$

\begin{tabular}{|c|l|}
\hline CLAY & AMOUNT \\
\hline Sagger XX $^{\circledR}$ & $169 \mathrm{~g} / \mathrm{L}$ \\
\hline OptiKasT $^{\circledR}$ & $138 \mathrm{~g} / \mathrm{L}$ \\
\hline
\end{tabular}

\subsection{BSR Equipment Description}

The BSR designed at SRNL is a two-stage unit used to produce the same mineralized products and gases as the ESTD FBSR (see Figure 7). Unlike the FBSR, the BSR is not fluidized since it had to fit in the SC and there is not enough height in the cells to allow for product disengagement. Steam does flow though the product freely, which is in the form of a biscuit, and Scanning Electron Microscopy (SEM) analysis shows well reacted particles in the BSR are similar to those in the FBSR, i.e. fully reacted (Figure 8). Only the first stage or DMR was used for this study. 


\section{Bench-scale Steam Reformer ․ㅗㅀ}

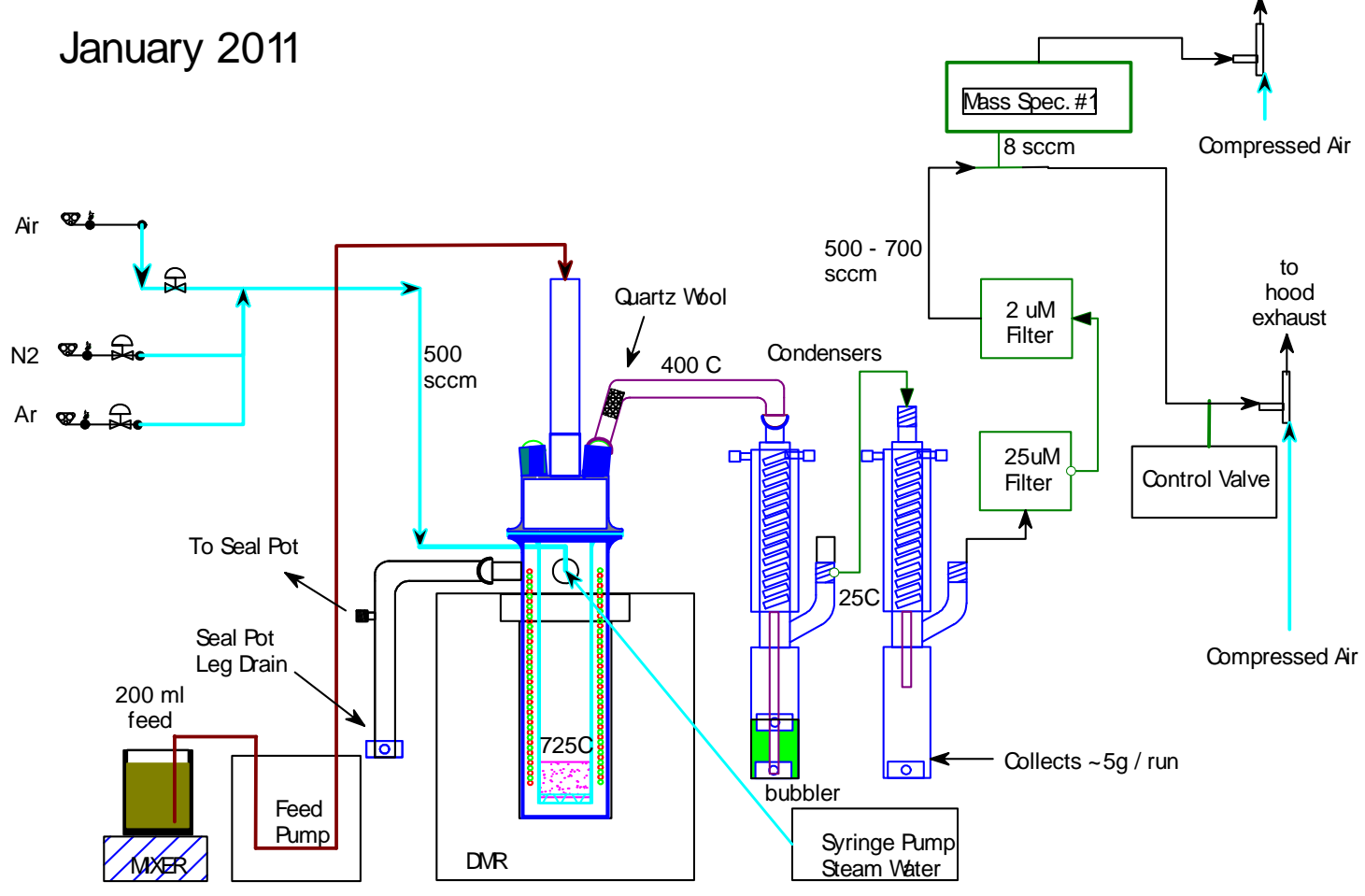

Figure 7. Schematic of the Bench-Scale Steam Reformer
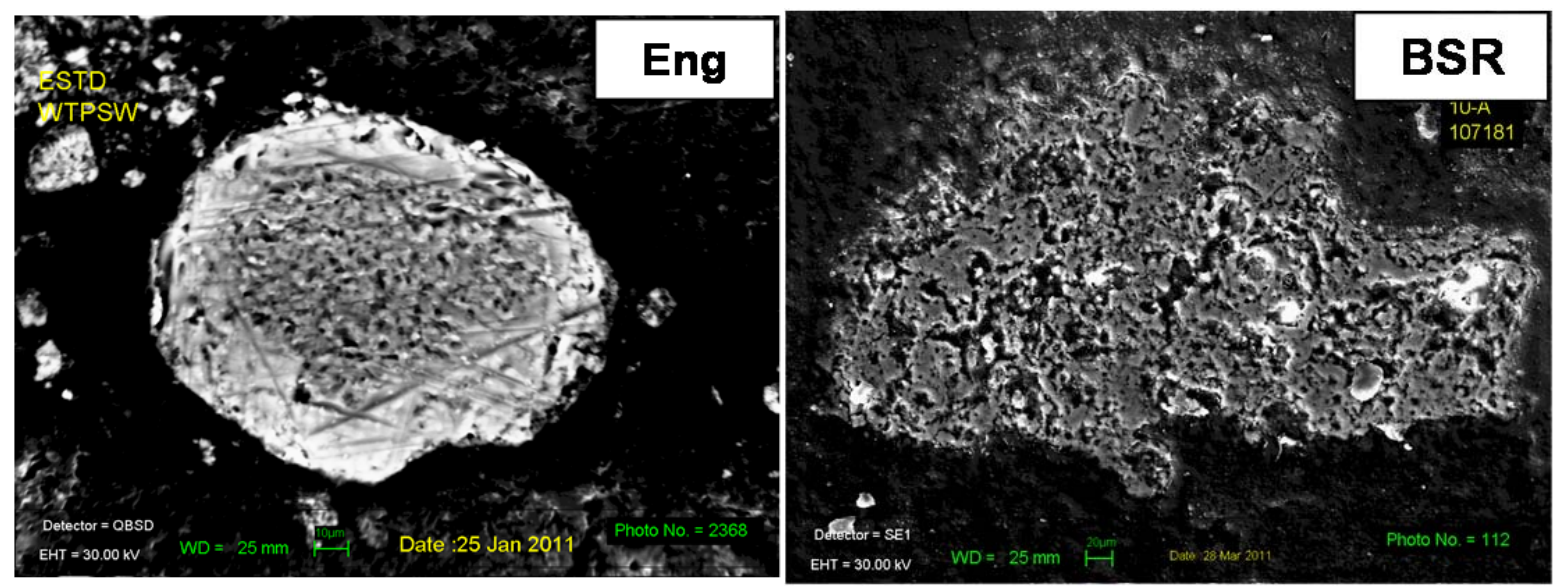

Figure 8. Comparison of the Reactivity of an Individual Particle from the Engineering Scale FBSR and the BSR. Note the similarity of the reaction texture.

The nomenclature for the reformer comes directly from the ESTD FBSR unit. During a typical run, approximately $200 \mathrm{~mL}$ of feed slurry was kept agitated with a stir bar mixer while a peristaltic pump fed the slurry through the center feed port in the lid of the DMR at about $1 \mathrm{~mL} / \mathrm{min}$. A mineralized product formed in the DMR (see Figure 9) in the presence of superheated steam, clay, and carbon and the offgases flow toward the DMR condenser. 
The condenser cooled the off-gas stream down to about $25^{\circ} \mathrm{C}$ and condensed the steam. A bubbler in the trap section of the condenser removed the remainder of the particulate carry-over. The off-gas was further cooled by a second condenser which condensed out about $5 \mathrm{~g}$ of water per run. The off-gas then passed through a 25 um filter and then a 2 um filter prior to being measured by a Mass Spectrometer (MS) for $\mathrm{H}_{2}$, $\mathrm{O}_{2}, \mathrm{CO}_{2}, \mathrm{~N}_{2}$, and Ar. An eductor drew the gases through the system and expelled them into the process exhaust system (chemical hood or shielded cell for SRNL) along with the motive air used to operate it. A control valve bled air into the suction side of the eductor to control the pressure of the DMR outer chamber to -4 inches of water column (in wc).

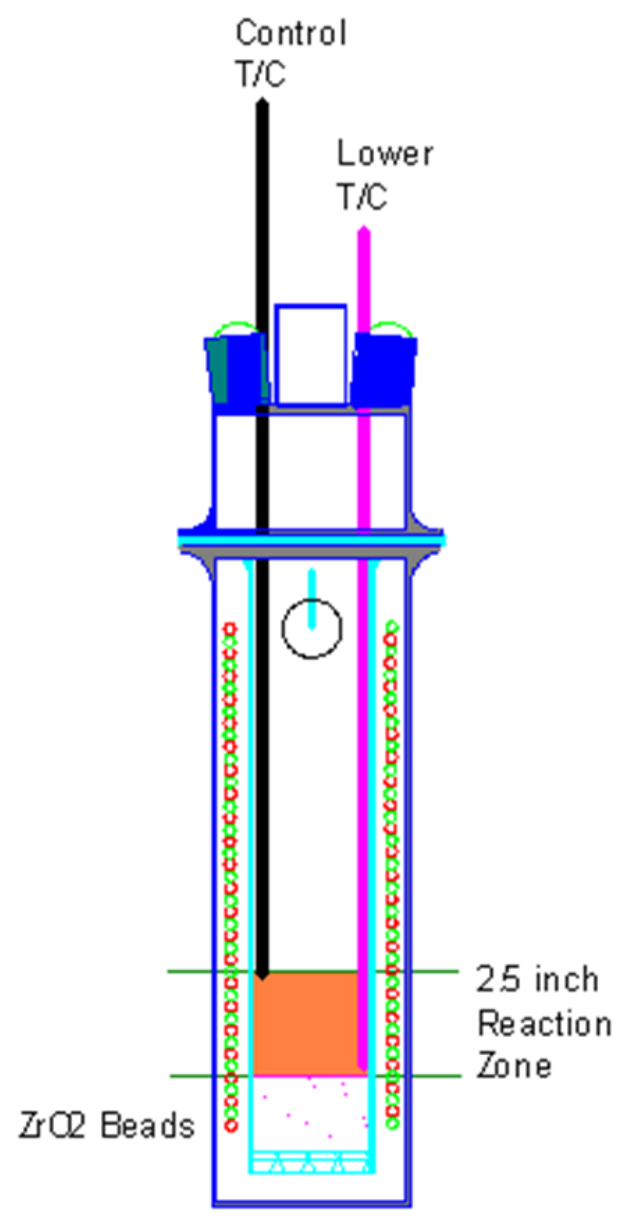

Figure 9. The Denitration Mineralization Reformer

The SRNL BSR DMR inner reaction chamber dimensions are $70 \mathrm{~mm}$ ID x $385 \mathrm{~mm}$ tall with a porous bottom. The bottom $50 \mathrm{~mm}$ ( 2 inches) is filled with zirconia beads. The zirconia beads were heavy enough not to be suspended by the gases and steam flowing up past them, acted as a base for the product to form on, allowed easy removal of the product from the reaction chamber, allowed easy separation of the product from the beads for analytic purposes, and provided a heat transfer medium for the gases that flow up through them. Zirconia beads are inert at the temperatures and oxygen fugacity at which the DMR operates and do not affect the steam reforming chemistry. 
The DMR outer chamber dimensions are $120 \mathrm{~mm}$ ID x $400 \mathrm{~mm}$ tall and provides connections for the outer chamber pressure relief and measurement line, and each of the two 20 foot coils which are housed between the DMR inner reaction chamber and the outer chamber. The outer chamber is sealed by the top flange of the inner chamber, and thus has a pressure relief line going to a seal pot which relieves at about 15 in wc. Water, $\mathrm{N}_{2}$, Ar, and air enter the DMR via the coils which are between the inner and outer walls of the DMR and are converted to superheated steam and hot gases with heat provided by the furnace that the DMR sat in. The steam and gases leave the coils and flow through the bottom of the DMR inner reaction chamber, the zirconia beads, the product, and out through the top of the DMR to the DMR condenser. The $\mathrm{N}_{2}+\mathrm{Ar}+$ Air total flow rate was held at a constant to improve process control.

The DMR lid is $120 \mathrm{~mm}$ ID $\times 80 \mathrm{~mm}$ tall and was sealed to the top of the inner chamber. The lid holds two type $\mathrm{K}$ thermocouples, the centered feed line that is cooled with standing water, the inner chamber pressure relief and measurement line, and the off-gas line going to the DMR condenser. In the event of an off-gas line pluggage, the inner chamber and lid have a pressure relief line going to a seal pot which relieves at about 15 in wc. One thermocouple was positioned at the level of the zirconia bead bed and the control thermocouple was positioned 2.5 inches above the surface of the bead bed. This 2.5 inch height was the upper point of the reaction zone in the DMR (see Figure 9).

The DMR off gas treatment system (see Figure 10) consisted of the crossover tube from the DMR to the condenser/bubbler, the condenser/bubbler, the second condenser, 25 um paper filter, and 2 um paper filter. It was necessary for pretreatment of the off gas to prevent pluggage or damage to the mass spectrometer. The system treated a combined controlled flow of ( $500 \mathrm{sccm}$ or $700 \mathrm{sccm}$ ) of Ar, $\mathrm{N}_{2}$, and air along with about $200 \mathrm{sccm}$ of reaction gases from the reforming process. It condensed from $0.4 \mathrm{~mL} / \mathrm{min}$ to 0.7 $\mathrm{mL} / \mathrm{min}$ water from the superheated steam plus about $0.7 \mathrm{~mL} / \mathrm{min}$ water from the slurry feed. The condenser/bubbler was capable of reducing the off gas stream temperature from $400^{\circ} \mathrm{C}$ to $25^{\circ} \mathrm{C}$.

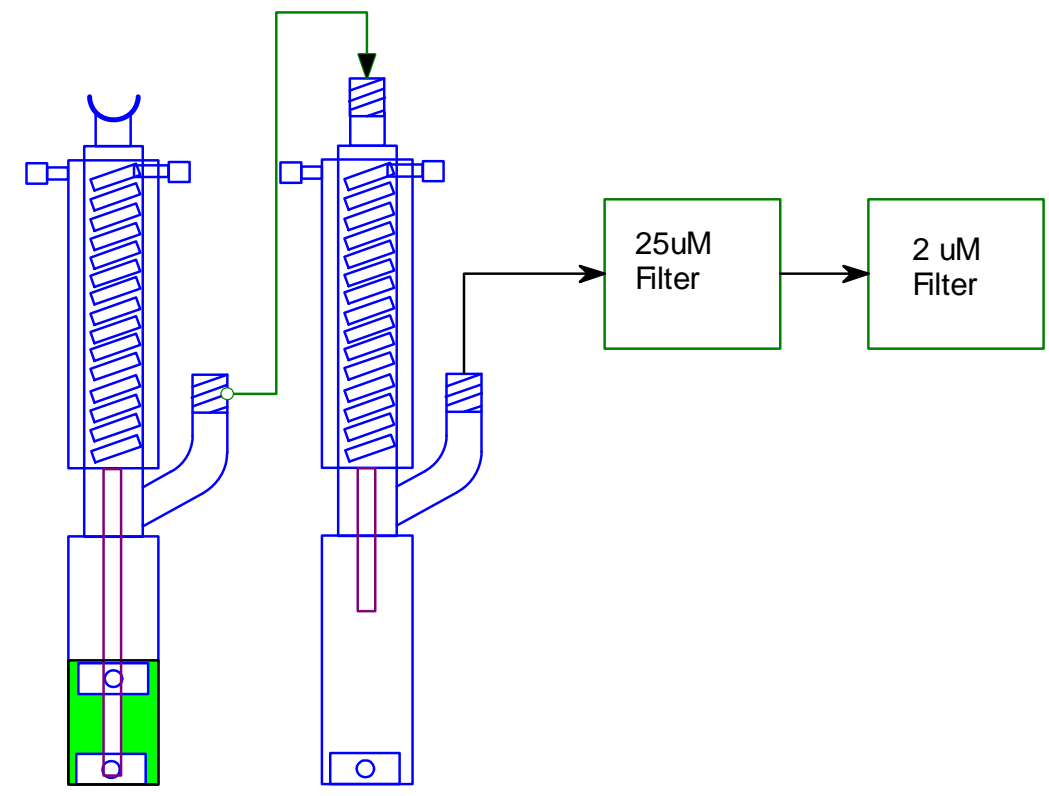

Figure 10. DMR Off Gas Treatment

The off-gases and steam entered at the top of the condenser/bubbler and flowed and condensed down through the center tube which ended at the bottom of a $75 \mathrm{~mm}$ deep water reservoir filled with zirconia beads. The condenser cooled the off-gas stream down to about $25^{\circ} \mathrm{C}$ and removed the steam and feed 
water. A bubbler in the trap section of the condenser removed the remainder of the particulate carry-over. Excess water from the bubbler would overflow into a sealed reservoir (not shown). The off-gas was further cooled by a second condenser which condensed out about $5 \mathrm{~g}$ of water per run. The off-gas then passed through a $25 \mu \mathrm{m}$ filter and then a $2 \mu \mathrm{m}$ filter prior to being measured by a Mass Spectrometer (MS). The $25 \mu \mathrm{m}$ filter trapped most of the vaporized sealing grease (that sealed the DMR flanges) such that the $2 \mu \mathrm{m}$ filter was seldom blinded. There were no pluggages of the mass spectrometer as a result of this system.

The BSR used a Monitor Instruments LAB 3000 Cycloidal MS for the reformer real time off gas analysis (see Figure 11). The spectrometer was set up to measure $\mathrm{H}_{2}, \mathrm{O}_{2}, \mathrm{~N}_{2}, \mathrm{CO}_{2}$, and argon. The MS would measure the DMR off-gas on channel 2. Channel 1 was used for the calibration gas. Both channels had 7 micron sintered metal filters in the $1 / 8$ " lines going to the instruments to prevent plugging the lines inside the MS.

Since the line pressure near the MS could go down to -25 in wc, it was necessary to run a second eductor and vacuum regulator to draw the sample gases through the MS. The vacuum was controlled to -40 in wc while the flow rate of gases pulled by an MS sample line was kept at $8 \mathrm{sccm}$. The flow rate of the gases coming from the DMR condenser varied between 500 to $700 \mathrm{sccm}$.

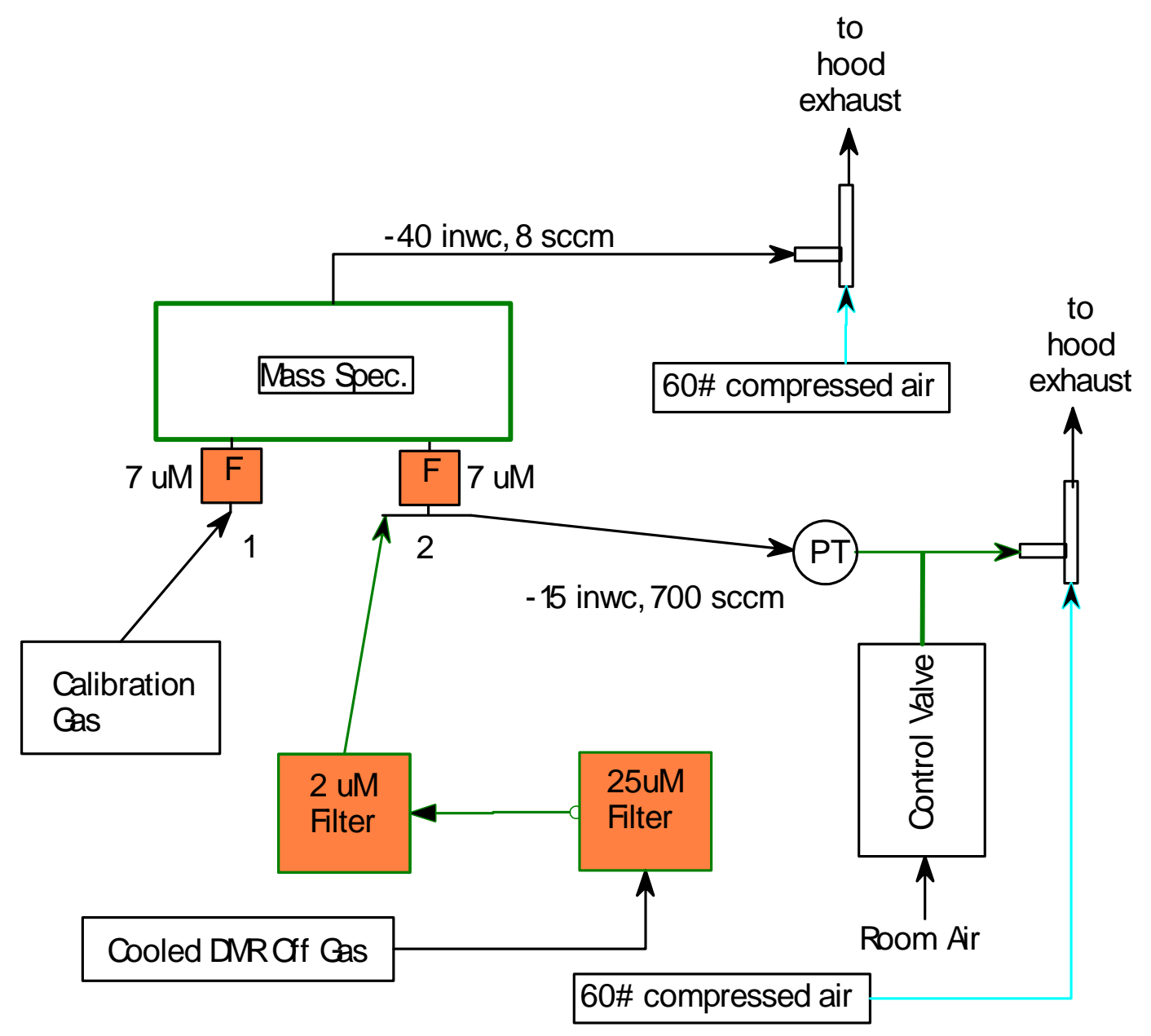

Figure 11. The BSR Mass Spectrometer 
The MS was controlled by a Personal Computer with Monitor Instruments proprietary software loaded. Data from the MS computer was transferred to the control computer in real time via a serial connection.

The DMR $\mathrm{H}_{2}$ values were continuously trended on the control computer and originally, operating personnel would manually vary the air flow into the DMR to control the DMR $\mathrm{H}_{2}$ value between $1.0 \%$ and $2.0 \%$ (dry basis). However, air flow was controlled to achieve the proper product REDOX for the WTP-SW re-runs performed in the Spring 2011 in the nominal range of 0.2 to $0.6 \mathrm{Fe}^{2+} / \Sigma \mathrm{Fe}$

For LOI control, the operator monitored the cumulative value of $\mathrm{CO}_{2} / \mathrm{mL}$ fed to the DMR and operated the DMR in post feed operation until a predetermined endpoint was achieved. This ensured the product did not have excessive unreacted coal in it. This was based on an imperfect mass balance of carbon since the MS did not measure $\mathrm{CO}$ which also is present in the off gas.

(Carbon fed into DMR) - (Carbon Leaving as $\left.\mathrm{CO}_{2}\right)=$ Unreacted carbon in product

The MS would determine and transmit the gas concentration data about once every 14 seconds. However, the lag time between the measurement and the conditions in the DMR ranged between 3 to 4 minutes depending on flow rates.

The computers for the MS and process control system along with the steam water pumps, MKS gas flow controllers, furnace controllers, furnace safety relays, and input/output box are located external to the cell on the operational side. The MS is in a radio-hood behind the cell on the maintenance side. Connections between process and control systems required the use of 9 inner wall connection tubes (known at SRNL as KAPL plugs which were first developed at Knolls Atomic Power Laboratory). Figure 12 provides a schematic of the system layout in the Shielded Cells. 
SRNL-STI-2011-00331

Revision 0

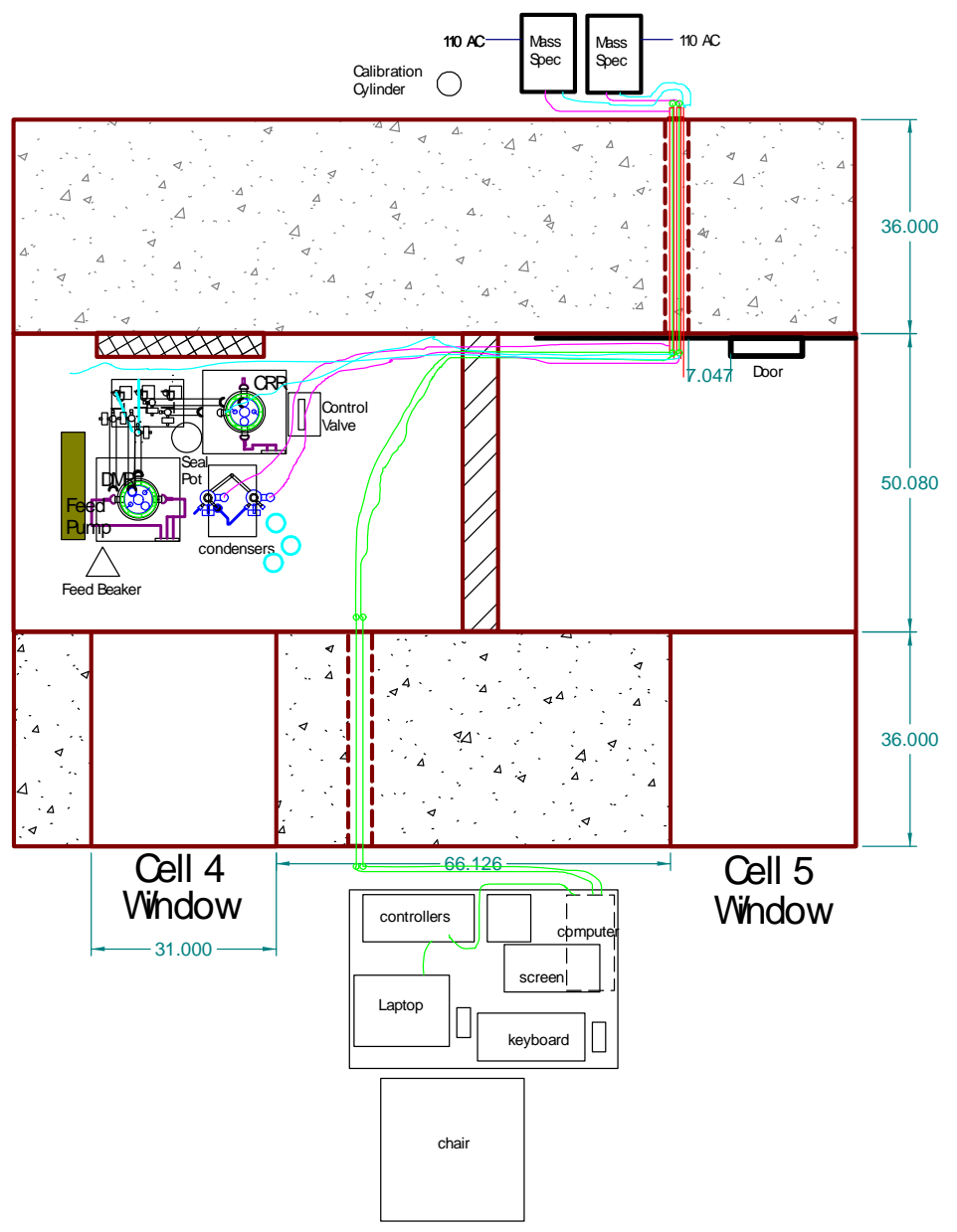

Figure 12. Total Rad System Layout at Cell 4 (Simplified)

The BSR was controlled by a single PC running Windows XP with 16 serial port connections.

Omniserver software was used as the server software to communicate through the serial ports. Intouch software was used as the client software and man machine interface. Data acquisition was continuous and trended in real time on screen as the process ran. Real time data was also saved to a file on a frequency of once per minute. Control logic was programmed into Intouch to provide operator aid (including a PID pressure controller). The Process Controller diagram is provided in Figure 13. 
SRNL-STI-2011-00331

Revision 0

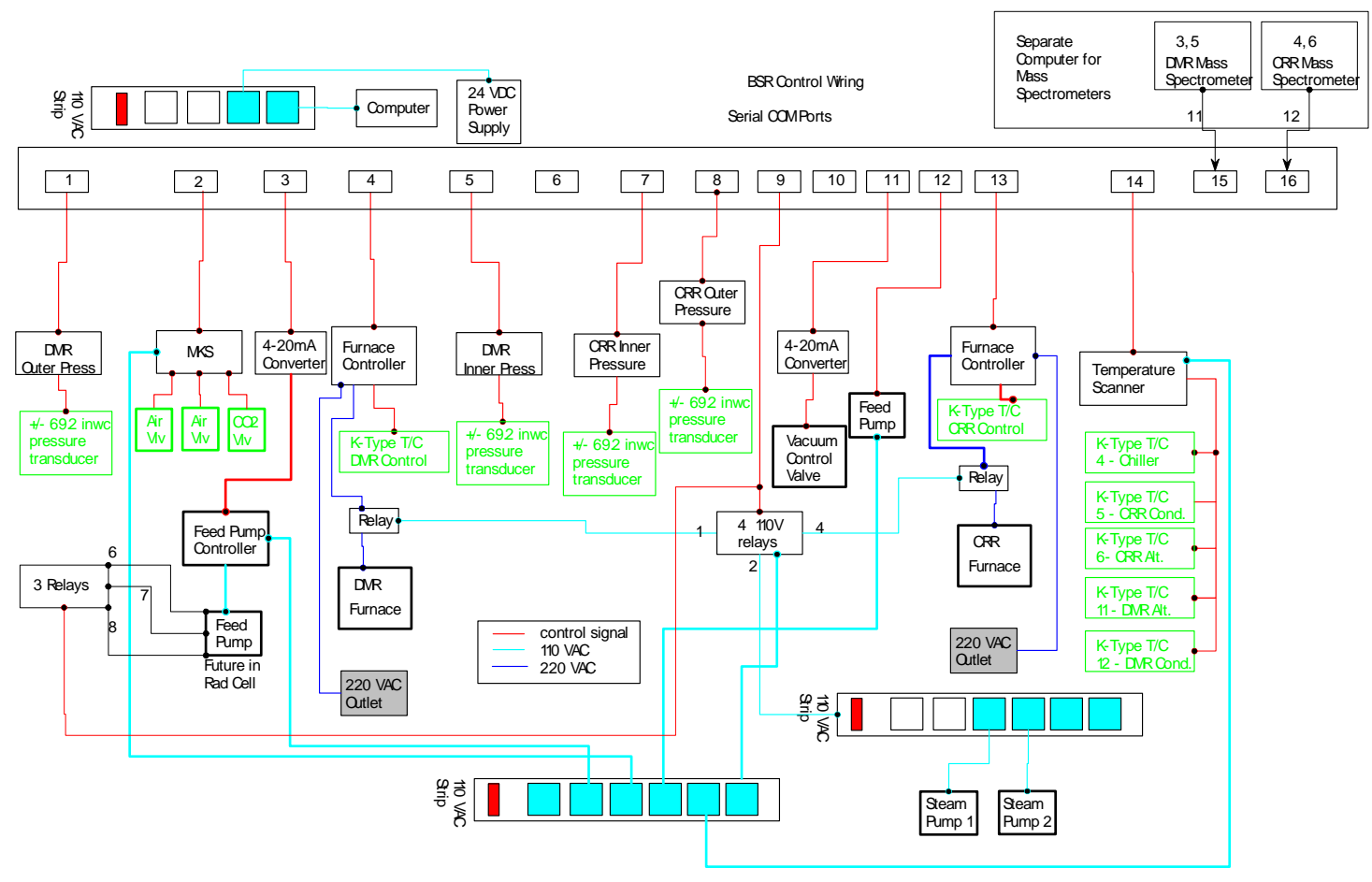

Figure 13. BSR Process Controller Diagram

The process parameters measured were:

Slurry Feed Rate, DMR outer pressure, DMR Inner Pressure, DMR Bed Temperature, DMR Control Temperature, DMR $\mathrm{H}_{2}$, DMR $\mathrm{O}_{2}$, DMR $\mathrm{N}_{2}, \mathrm{DMR} \mathrm{CO}_{2}$, DMR argon, filter pressure inlet, Filter Pressure outlet, and chiller bath temperature.

The process parameters controlled were:

Slurry Feed Rate, DMR Control Temperature, DMR outer pressure, and the DMR Air flow-rate coupled to the $\mathrm{N}_{2}$ and Ar flowrates.

\subsection{BSR Processing Conditions}

The WTP-SW campaigns were performed at three different times sufficiently spaced apart that the process control technology advanced between each campaign. Campaigns were performed in the Fall of 2009 using surrogate feed and relatively high coal levels. Surrogate feed campaigns were again performed in August of 2010 at reduced coal levels to target lower residual coal levels in the BSR granular product. Two radioactive feed BSR runs were then performed shortly after the August 2010 surrogate runs in September of 2010. All of the 2009 and 2010 BSR campaigns used measured $\mathrm{H}_{2}$ gas concentrations as the critical process control. A final set of surrogate feed BSR runs were performed in the Spring of 2011 that used a more recently developed 'REDOX control strategy' [49] that is described in more detail later in this report. The purpose of these latter 2011 BSR runs was to produce more granular product for the monolith tasks (previous Fall 2009 and Fall 2010 surrogate BSR granular product has been consumed in 
the failed monolith attempts). Another goal of these latter Spring 2011 BSR runs was to investigate further the mass balance of the BSR runs under REDOX control operational strategy.

Table 13 shows the parameters used in the BSR as compared to typical FBSR parameters. The first two data columns in Table 13 simply show the parameters in different units. The feed rate of $\sim 1 \mathrm{~mL} / \mathrm{min}$ for the DMR was established based on the equipment's ability to pump the clay/coal/waste slurries and the DMR's ability to convert it to mineral product without the presence of unreacted product. Coal was fed at a rate of $0.20 \mathrm{~g} / \mathrm{min}$, which is less than the $0.35 \mathrm{~g} / \mathrm{min}$ scaled equivalent because the BSR does not use coal to auto-catalytically heat the DMR and excess unreacted coal in the product is undesirable because it adds unnecessary volume to the product and causes REDOX measurement problems. Total gas flow was as high as reasonable, but limited based on observed solids carry over. Using nitrogen from a cylinder, the total gas flow could be controlled to allow for inert conditions (no air inleakage with $100 \% \mathrm{~N}_{2}$ ) all the way up to $100 \%$ air. The measured $\mathrm{H}_{2}$ gas concentration was the critical control parameter for the 2008 HRI ESTD FBSR and initial 2009 and 2010 campaigns performed with the SRNL BSR. The $\mathrm{H}_{2}$ concentration was maintained at the nominal range of 1 to 3\% (dry basis) shown in Table 13 by the amount of air inleakage allowed into the BSR system. The DMR temperatures were the same as in the engineering and pilot scale FBSR. The BSR ran at a slightly negative pressure where the ESTD FBSR runs at a slightly positive pressure. All operational conditions were approved by TTT before the runs and conditions are documented in the lab notebook SRNL-NB-2009-00115.

Table 13. Relative Scaling of Process Operating Parameters, FBSR vs BSR

\begin{tabular}{|l|c|c|c|c|}
\hline \multicolumn{1}{|c|}{ Parameter } & FBSR & FBSR & Scaled BSR & Actual BSR \\
\hline Feed Rate & $0.2 \mathrm{gpm}$ & $757 \mathrm{~mL} / \mathrm{min}$ & $1 \mathrm{~mL} / \mathrm{min}$ & $1 \mathrm{~mL} / \mathrm{min}$ \\
\hline Coal Rate & $35 \mathrm{lbs} / \mathrm{hr}$ & $265 \mathrm{~g} / \mathrm{min}$ & $0.35 \mathrm{~g} / \mathrm{min}$ & $0.2 \mathrm{~g} / \mathrm{min}$ \\
\hline Gas Rate & $101.9 \mathrm{scfm}$ & $2885 \mathrm{SLM}$ & $3.8 \mathrm{SLM}$ & $0.7 \mathrm{SLM}$ \\
\hline Steam Rate & -- & -- & -- & $36 \mathrm{~mL} / \mathrm{hr}$ \\
\hline H$_{\mathbf{2}}$ Conc. & $1 \%-2 \%$ & -- & -- & $1 \%-3 \%$ \\
\hline DMR Temp. & $720^{\circ} \mathrm{C}$ & -- & -- & $720^{\circ} \mathrm{C}$ \\
\hline Pressure & +2 to $+3 \mathrm{psig}$ & -- & -- & $-3 \mathrm{in} \mathrm{wc}$ \\
\hline
\end{tabular}

The DMR has two thermocouples for measuring the reaction zone temperature. The placement of these thermocouples changed and the choice of the controlling thermocouple changed over the course of the runs performed. Originally, the controlling thermocouple was 1 inch into the beads and the upper thermocouple was positioned 4 inches above the beads. This configuration was very uncontrollable due to the water and steam from the slurry making contact with the controlling thermocouple. Later, the controlling thermocouple was positioned $2 \frac{1}{2}$ inches above the beads and the lower thermocouple was at the bead surface. This configuration worked best and has been used since.

Off-gas conditioning also went through configuration changes during the testing. Off-gas conditioning is performed to protect the mass spectrometer, which measures the off gas downstream. Originally, the gases leaving the condenser bubbler were treated by a dry ice condenser, which removed about $8 \mathrm{ml}$ of water per run. After trying different configurations and filters, the gases leaving the condenser bubbler were treated by a standard secondary condenser which collected about $5 \mathrm{~g}$ water per run followed by a 25 micron filter and then a 2 micron filter and this configuration has remained unchanged.

Initial plugging of the 25 micron paper filters was attributed to the degradation of the sealing grease at the top of the DMR. Though the grease is rated to $810^{\circ} \mathrm{C}$ (and the DMR ran at $720^{\circ} \mathrm{C}$ ), it was still degrading to a dry crust by the end of the DMR runs. The grease degradation also had the potential to cause air inleakage, diluting the readings on the mass spectrometer. Insulation on the DMR top seal was removed 
to reduce the temperature of the grease seal which alleviated the problems increasing the 25 micron filter use to about 10 - 15 runs before replacement. Pressure transducers were inserted before and after the two filters to aid operators in determining the replacement time.

The same coal was added as was used by the ESTD FBSR as a reducing agent. However, for the BSR, the coal was ground, then sifted through an 80 mesh sieve (177 microns) and mixed with the feed slurry prior to being pumped into the DMR versus the ESTD coal which was not size reduced and was added as a separate stream in the FBSR.

In addition, a small amount of $\mathrm{Fe}\left(\mathrm{NO}_{3}\right)_{3} \bullet 9 \mathrm{H}_{2} \mathrm{O}$ was added to the BSR runs to act as an analytical indicator for the REDOX potential in the product, typically targeting nominally $1 \mathrm{wt} \%$ elemental iron in the BSR mineral product. The REDOX measurement was used to determine the expected distribution of ${ }^{99} \mathrm{Tc}$ and other REDOX sensitive species in the product.

\subsection{BSR Mass Balance}

The BSR is a simpler design than the ESTD facility in Golden, CO and so it is easier to perform a mass balance. For the WTP-SW, there were five mass balance product vectors and one feed vector. The product vectors were composed of the product solids, the solids in a cross bar that provided a pathway to a condenser, the solids in the condenser, cross bar rinses to determine if any species adhered to the crossbar, and the condenser solution.

The mass balance calculational approach for the WTP SW simulant and radioactive campaigns consisted of identifying key input and output streams and then analyzing these streams for key species. Before each radioactive module, a simulant module was performed to identify the proper control parameters and sampling techniques. The mass balance streams that could be analyzed for the simulant campaigns were greater due to the limitations of the radioactive systems, i.e., accessibility to various streams given the physical constraints of the cells operations.

The key input and output streams for which mass balance calculations were performed are shown in Table 14 and Table 15, respectively.

Table 14. Key Input Streams for Simulant and Radioactive WTP SW

\begin{tabular}{|l|l|}
\hline \multicolumn{1}{|c|}{ INPUT STREAM } & \multicolumn{1}{c|}{ COMMENT } \\
\hline Feed-Supernate & Portion of Feed that is simulant or radioactive waste \\
\hline Feed-Fe $\left(\mathrm{NO}_{3}\right)_{3}{ }^{*} 9 \mathrm{H}_{2} \mathrm{O}$ & Portion of Feed that is REDOX indicator \\
\hline Feed-Coal & Portion of Feed that is unreacted Coal \\
\hline Feed-Coal Ash & Portion of Feed that is reacted coal or coal ash \\
\hline Feed-Clay-OptiKasT ${ }^{\circledR}$ & Portion of Feed that is OptiKasT ${ }^{\circledR}$ Clay \\
\hline Feed-Clay-Sagger $\mathrm{XX}^{\circledR}$ & Portion of Feed that is Sagger XX ${ }^{\circledR}$ Clay \\
\hline
\end{tabular}


Table 15. Key Output Streams for Simulant and Radioactive WTP SW

\begin{tabular}{|l|c|c|c|}
\hline \multicolumn{1}{|c|}{ OUTPUT STREAM } & $\begin{array}{c}\text { FALL (AUGUST) } \\
\text { 2010 SIMULANT } \\
\text { RUNS }\end{array}$ & $\begin{array}{c}\text { REPEAT - SPRING } \\
\text { 2011 SIMULANT } \\
\text { RUNS }\end{array}$ & $\begin{array}{c}\text { FALL } \\
\text { (SEPTEMBER) 2010 } \\
\text { RADIOACTIVE } \\
\text { RUNS }\end{array}$ \\
\hline Granular Product & Yes & Yes & Yes \\
\hline DMR Condensate Filtrate & Yes & Yes & Yes \\
\hline DMR Condensate Solids & Yes & Yes & Yes \\
\hline Crossbar Filtrate & Yes & Yes & Yes \\
\hline Crossbar Solids & Yes & Yes & No \\
\hline Seal Pot Filtrate & No & Yes & No \\
\hline Seal Pot Solids & No & & \\
\hline
\end{tabular}

The key input and output streams for the simulant mass balances are shown pictorially in Figure 14 and Figure 15. Note that in the Spring 2011 WTP SW simulant runs that samples were taken from the seal pots to get better closure on the mass balance. Note that the mass balance input and output streams are in yellow boxes.

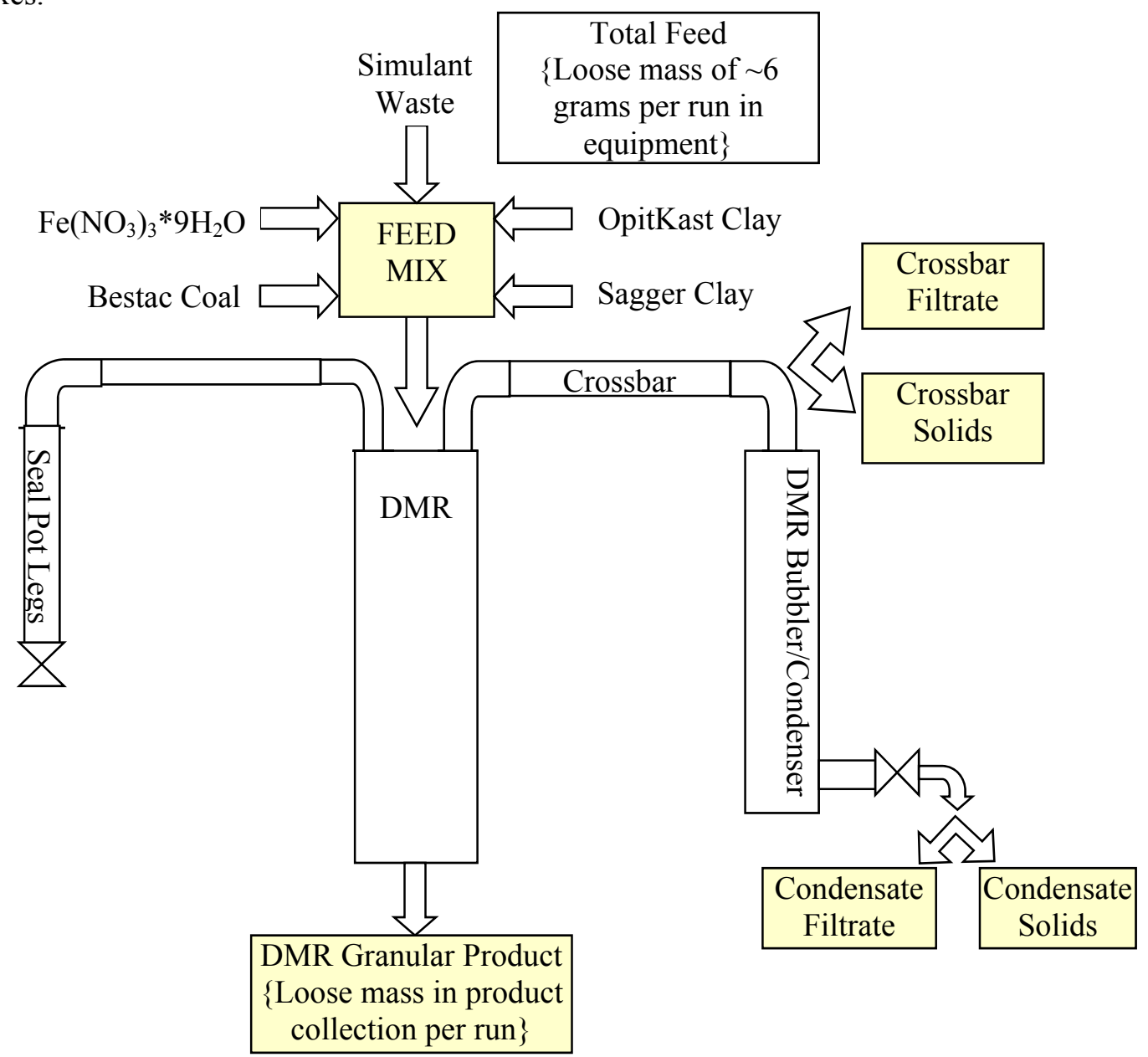

Figure 14. Mass Balance Input and Output Streams for Simulant WTP SW 
SRNL-STI-2011-00331

Revision 0

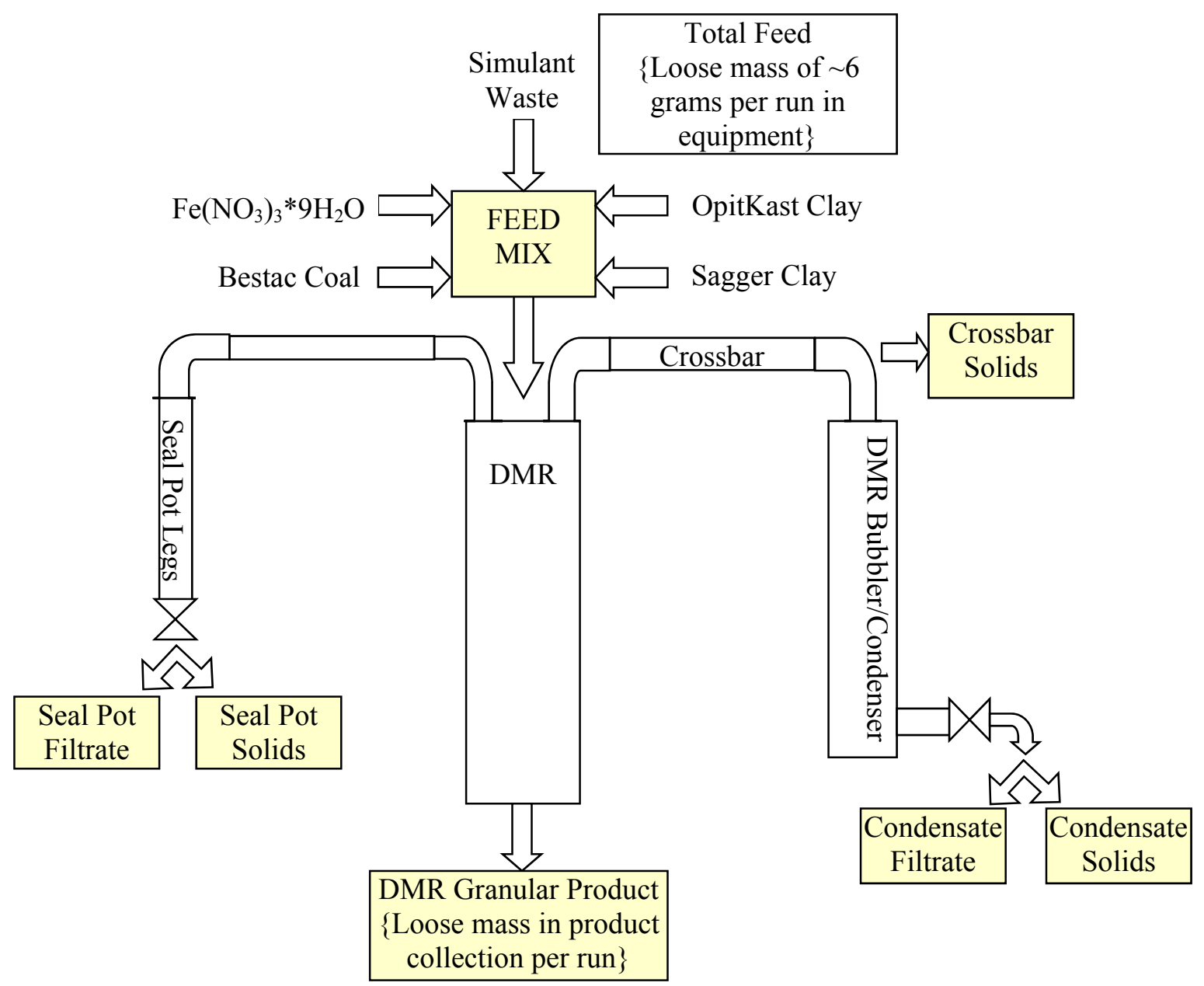

Figure 15. Input and Output Streams for Repeat (Spring 2011) Simulant WTP SW

The key input and output streams for the radioactive mass balances are shown pictorially in Figure 16. Due to the timing of the radioactive experiments and the limitations in the Shielded Cells, no seal pot samples were collected. 
SRNL-STI-2011-00331

Revision 0

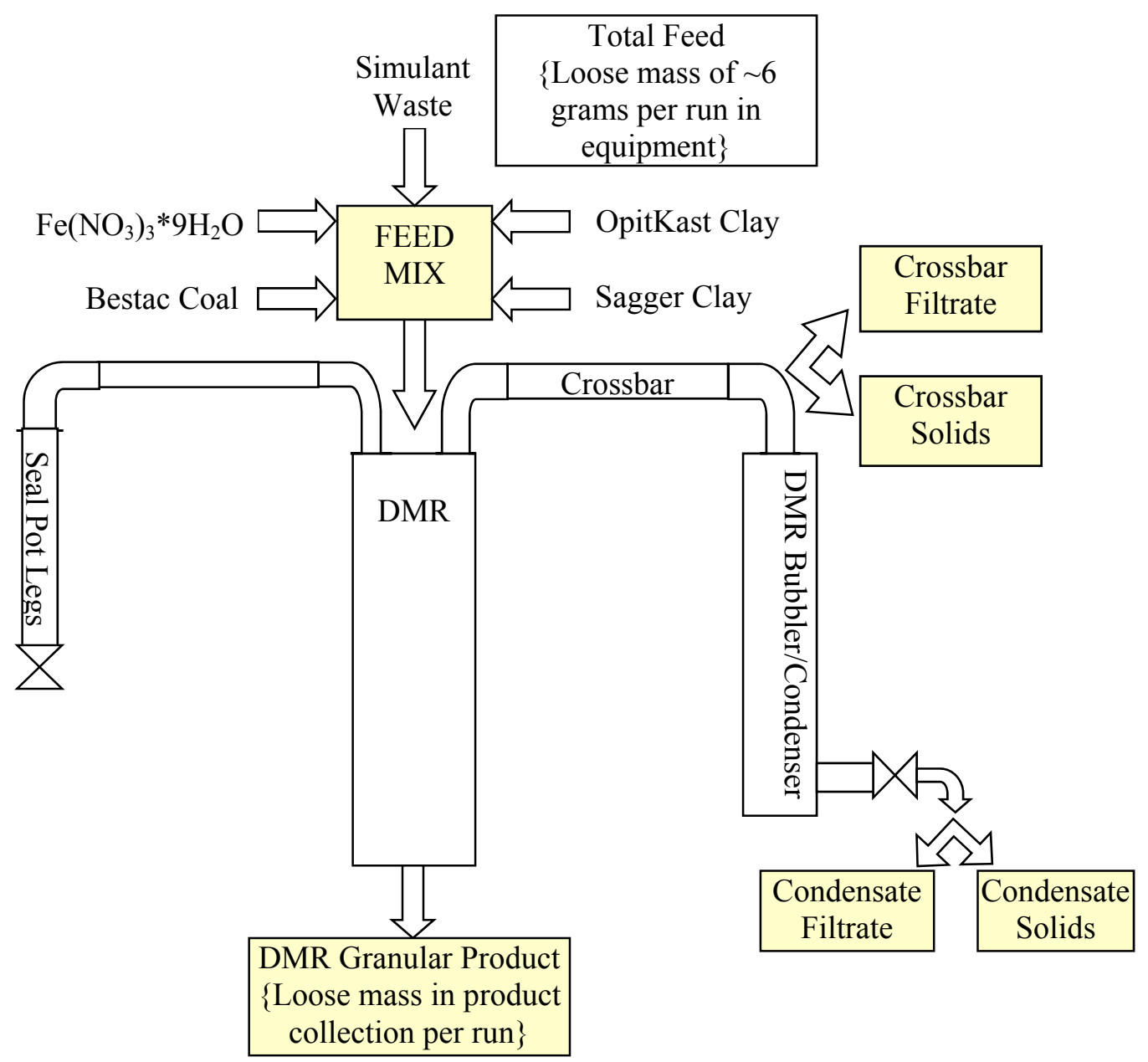

Figure 16. Input and Output Streams for Radioactive WTP SW

The key species examined in the simulant and radioactive campaigns for the mass balance are shown in Table 16.

Table 16. Key Species for Mass Balance

\begin{tabular}{|c|c|}
\hline Radioisotope Species & Non-Radioactive Species \\
\hline${ }^{137} \mathrm{Cs}$ & ${ }^{133} \mathrm{Cs}$ \\
\hline${ }^{125} \mathrm{I}$ & $\mathrm{Re}$ \\
\hline${ }^{129} \mathrm{I}$ & ${ }^{127} \mathrm{I}$ \\
\hline${ }^{99} \mathrm{Tc}$ & $\mathrm{Al}$ \\
\hline & $\mathrm{Cl}$ \\
\hline & $\mathrm{Cr}$ \\
\hline & $\mathrm{Na}$ \\
\hline & $\mathrm{Si}$ \\
\hline & $\mathrm{SO}_{4}{ }^{2-}$ \\
\hline
\end{tabular}

Using the input and output streams described earlier, the mass balance calculational logic can be described as shown below: 
SRNL-STI-2011-00331

Revision 0

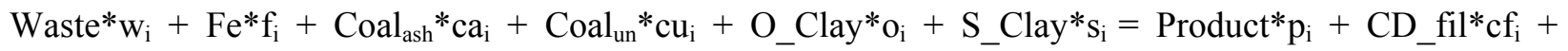
CD_sol* $\mathrm{cs}_{\mathrm{i}}+\mathrm{XR} \_$fil $* \mathrm{xf}_{\mathrm{i}}+\mathrm{XR} \_$sol* $\mathrm{xs}_{\mathrm{i}}+\mathrm{SP} \_\mathrm{fil}^{*} \mathrm{sf}_{\mathrm{i}}+\mathrm{SP} \_\mathrm{sol}^{*} \mathrm{ss}_{\mathrm{i}}$

Where:

$\mathrm{i}=$ One of key species identified earlier

Waste $=$ mass of simulant or radioactive waste stream

$\mathrm{Fe}=$ mass of $\mathrm{Fe}\left(\mathrm{NO}_{3}\right)_{3} \bullet 9 \mathrm{H}_{2} \mathrm{O}$ added to waste stream

$\mathrm{Coal}_{\text {ash }}=$ mass of Bestac Coal that remains in granular product as coal ash

$\mathrm{Coal}_{\mathrm{un}}=$ mass of Bestac Coal that remains unreacted in granular product

O_Clay, S_Clay $=$ mass of OpitKasT ${ }^{\circledR}$ and Sagger $\mathrm{XX}^{\circledR}$ Clay added to waste stream, respectively

$\mathrm{w}_{\mathrm{i}}, \mathrm{f}_{\mathrm{i}}, \mathrm{ca}_{\mathrm{i}}, \mathrm{cu}_{\mathrm{i}}, \mathrm{o}_{\mathrm{i}}, \mathrm{s}_{\mathrm{i}}$ are concentrations of species $\mathrm{i}$ for waste, $\mathrm{Fe}\left(\mathrm{NO}_{3}\right)_{3} * 9 \mathrm{H}_{2} \mathrm{O}$, Coal Ash, Unreacted Coal, OpitKast Clay, and Sagger Clay streams, respectively

Product $=$ mass of solid granular product

$\mathrm{p}_{\mathrm{i}}=$ concentration of species $\mathrm{i}$ in solid granular product

CD_fil $=$ mass of DMR condensate filtrate

$\mathrm{cf}_{\mathrm{i}}=$ concentration of species $\mathrm{i}$ in DMR condensate filtrate

CD_sol $=$ mass of DMR condensate solids

$\mathrm{Cs}_{\mathrm{i}}=$ concentration of species $\mathrm{i}$ in DMR condensate solids

XR_fil $=$ mass of crossbar filtrate from rinse and filtering

$\mathrm{xf}_{\mathrm{i}}=$ concentration of species $\mathrm{i}$ in crossbar filtrate from rinse and filtering

XR_sol $=$ mass of crossbar solids from quartz wool and/or rinse filtering

$\mathrm{Xs}_{\mathrm{i}}=$ concentration of species $\mathrm{i}$ in crossbar solids from quartz wool and/or rinse filtering

SP_fil = mass of seal pot leg filtrate from drains or rinses

$\mathrm{sf}_{\mathrm{i}}=$ concentration of species $\mathrm{i}$ in seal pot leg filtrate from drains or rinses

SP_sol = mass of seal pot leg solids from drains or rinses

$\mathrm{ss}_{\mathrm{i}}=$ concentration of species $\mathrm{i}$ in seal pot leg solids from drains or rinses

Only for the Spring 2011 simulant runs were there both seal pot leg filtrates and solids from drains and rinses. In the earlier simulant and the radioactive runs, there were no seal pot samples.

Based on a special BSR run that was done for a Hanford LAW sample known as Module D, the feed mass per run for this testing was overestimated by about 6 grams per run. The original Fall 2010 simulant testing consisted of 2 runs so the total measured feed of about $623 \mathrm{~g}$ was decreased by 12 grams to about $611 \mathrm{~g}$. The Spring 2011 campaigns had 5 runs so the total measured feed of about $498 \mathrm{~g}$ was decreased by $30 \mathrm{~g}$ to about $468 \mathrm{~g}$. The radioactive campaign had 2 runs so the total measured feed of about $433 \mathrm{~g}$ was decreased by 12 grams to about $421 \mathrm{~g}$. 
The special BSR run for Module D also showed that the granular product mass was being underestimated due to losses in the collection and processing of the granular product for each run. Since the granular product collection and processing techniques differed from the simulant versus radioactive modules as well as across different researchers and technicians, a calcined factor for the BSR was developed with respect to the mass of granular product produced per mass of feed coming into the system. After studying the various granular product masses and corrected feed masses across the simulant and radioactive Modules $\mathrm{B}$ and $\mathrm{C}$ activities, it was determined that:

$$
\mathrm{C}_{\mathrm{f}}=\frac{\text { Product }}{\text { Waste }+ \text { O_Clay }+\mathrm{S}_{-} \text {Clay }+\mathrm{Fe}+\mathrm{Coal}_{\text {ash }}+\mathrm{Coal}_{\text {un }}}=0.3
$$

Where:

$$
\mathrm{C}_{\mathrm{f}}=\text { Calcined factor for BSR }
$$

Waste $=$ mass of simulant or radioactive waste stream fed

$$
\mathrm{Fe}=\text { mass of } \mathrm{Fe}\left(\mathrm{NO}_{3}\right)_{3} \bullet 9 \mathrm{H}_{2} \mathrm{O} \text { fed }
$$

O_Clay, S_Clay $=$ mass of OptiKasT ${ }^{\circledR}$ and Sagger $\mathrm{XX}^{\circledR}$ Clay fed, respectively

$$
\mathrm{Coal}_{\mathrm{ash}}=\text { mass of Bestac Coal that remains in granular product as coal ash }
$$

$\mathrm{Coal}_{\mathrm{un}}=$ mass of Bestac Coal that remains unreacted in granular product

To calculate the unreacted Bestac coal remaining after the BSR processing, the LOI and LOD measurements were performed on each run's granular product. Using the LOI and LOD measurements, the $\mathrm{wt} \%$ carbon remaining in the granular product at the end of each run $\left(\mathrm{c}_{\mathrm{wt}} \%\right)$ were calculated as follows:

$$
\mathrm{c}_{\mathrm{wt}} \%=\mathrm{LOI}-\mathrm{LOD}
$$

The Bestac coal contains $82.49 \% \mathrm{wt} \%$ carbon based on analytical data received by SRNL from TTT. Using the $\mathrm{c}_{\mathrm{wt}} \%$ and the known $\mathrm{wt} \%$ carbon in the Bestac coal, the amount of unreacted coal per run was calculated as follows:

$$
\text { Coal }_{\text {un }}=\frac{\text { Product } * \mathrm{c}_{\mathrm{wt}} \%}{82.49 \%}
$$

Knowing the total mass of coal fed per run (Coal), the amount of coal that gets ashed per run $\left(\mathrm{Coal}_{\text {ashed }}\right)$ is calculated as follows:

$$
\mathrm{Coal}_{\text {ashed }}=\mathrm{Coal}-\mathrm{Coal}_{\mathrm{un}}
$$

Using the measured wt $\%$ ash in the Bestac Coal of $5.11 \%$, the mass of coal ash that remains behind in the granular product per run $\left(\mathrm{Coal}_{\text {ash }}\right)$ was then calculated as follows:

$$
\mathrm{Coal}_{\text {ash }}=\mathrm{Coal}_{\text {ashed }} * 5.11 \%
$$


SRNL-STI-2011-00331

Revision 0

The mass of product produced per run is then calculated using the BSR calcined factor $\left(\mathrm{C}_{\mathrm{f}}\right)$ and the various output masses as described above:

$$
\text { Product }=\left(\text { Waste }+ \text { O_Clay }+\mathrm{S} \_ \text {Clay }+\mathrm{Fe}+\mathrm{Coal}_{\text {ash }}+\mathrm{Coal}_{\text {un }}\right) * 0.3
$$

Once the masses and concentrations have been determined, the percent recovery of species i for a particular output stream $\mathrm{j}$ is calculated as follows:

$$
\operatorname{Rec}_{i, j}=\text { Out }_{i, j} / \operatorname{In}_{\mathrm{i}}
$$

Where:

$\operatorname{Rec}_{\mathrm{i}, \mathrm{j}}=$ Percent Recovery of species $\mathrm{i}$ for a particular output stream $\mathrm{j}$

Out $_{\mathrm{i}, \mathrm{j}}=$ Output Stream j Mass of Species $\mathrm{i}$, which would be Product* $\mathrm{p}_{\mathrm{i}}, \mathrm{CD} \_$fil ${ }^{*} \mathrm{cf}_{\mathrm{i}}, \mathrm{CD}_{-} \mathrm{sol}^{*} \mathrm{cs}_{\mathrm{i}}$, $\mathrm{XR} \_$fil ${ }^{*} \mathrm{xf}_{\mathrm{i}}, \mathrm{XR} \_\mathrm{sol}^{*} \mathrm{xs} \mathrm{i}_{\mathrm{i}}, \mathrm{SP} \_$fil ${ }^{*} \mathrm{sf}_{\mathrm{i}}$, or $\mathrm{SP} \_\mathrm{sol}^{*} \mathrm{ss}_{\mathrm{i}}$ for the various streams

$$
\mathrm{In}_{\mathrm{i}}=\text { Total Input Mass of Species } \mathrm{i}=\text { Waste }^{*} \mathrm{w}_{\mathrm{i}}+\mathrm{Fe}^{*} \mathrm{f}_{\mathrm{i}}+\mathrm{Coal}^{*} \mathrm{c}_{\mathrm{i}}+\mathrm{O}_{-} \text {Clay }{ }_{\mathrm{o}} \mathrm{o}_{\mathrm{i}}+\mathrm{S} \_ \text {Clay*} \mathrm{s}_{\mathrm{i}}
$$

The total recovery of species $i$ for all streams $j$ then becomes:

$$
\begin{aligned}
\operatorname{Rec}_{i} & =\sum_{j} \operatorname{Rec}_{i, j} \\
\operatorname{Rec}_{\mathrm{i}} & =\text { Percent Total Recovery of species i across all output streams }
\end{aligned}
$$

The recovery of species i across $\mathrm{j}$ streams is then normalized to $100 \%$ by:

$$
\overline{\operatorname{Rec}}_{i, j}=\frac{\operatorname{Rec}_{i, j}}{\sum_{j} \operatorname{Rec}_{i, j}}
$$

Where:

$$
\overline{\operatorname{Rec}}_{i, j}=\text { normalized percent recovery of species } \mathrm{i} \text { in stream } \mathrm{j}
$$

\subsection{Monolith Fabrication and Curing}

Monolith formation for the granular products produced from the BSR were initially started using the GEO-7 fly ash geopolymer formulation resulting from previous SRNL monolith studies on HRI ESTD FBSR LAW and WTP-SW products produced in 2008 [22]. The previous work optimized monolith formation based on LAW FBSR products (not WTP-SW FBSR products). However, in that work, several different monolith sizes of 2"x 4", 3" x 6" and 6" x 12" cylinders were also fabricated with the WTP-SW ESTD FBSR granular products. These WTP-SW GEO-7 monoliths gave satisfactory PCT durability, TCLP and compressive strength results so this GEO-7 formulation was specified as the monolith recipe to use in this Module A BSR work. A ternary diagram showing both the previous literature geopolymer region shown as the blue G1 'centroid' and the composition of both the LAW and WTP-SW FBSR mineral products is given in Figure 17. 


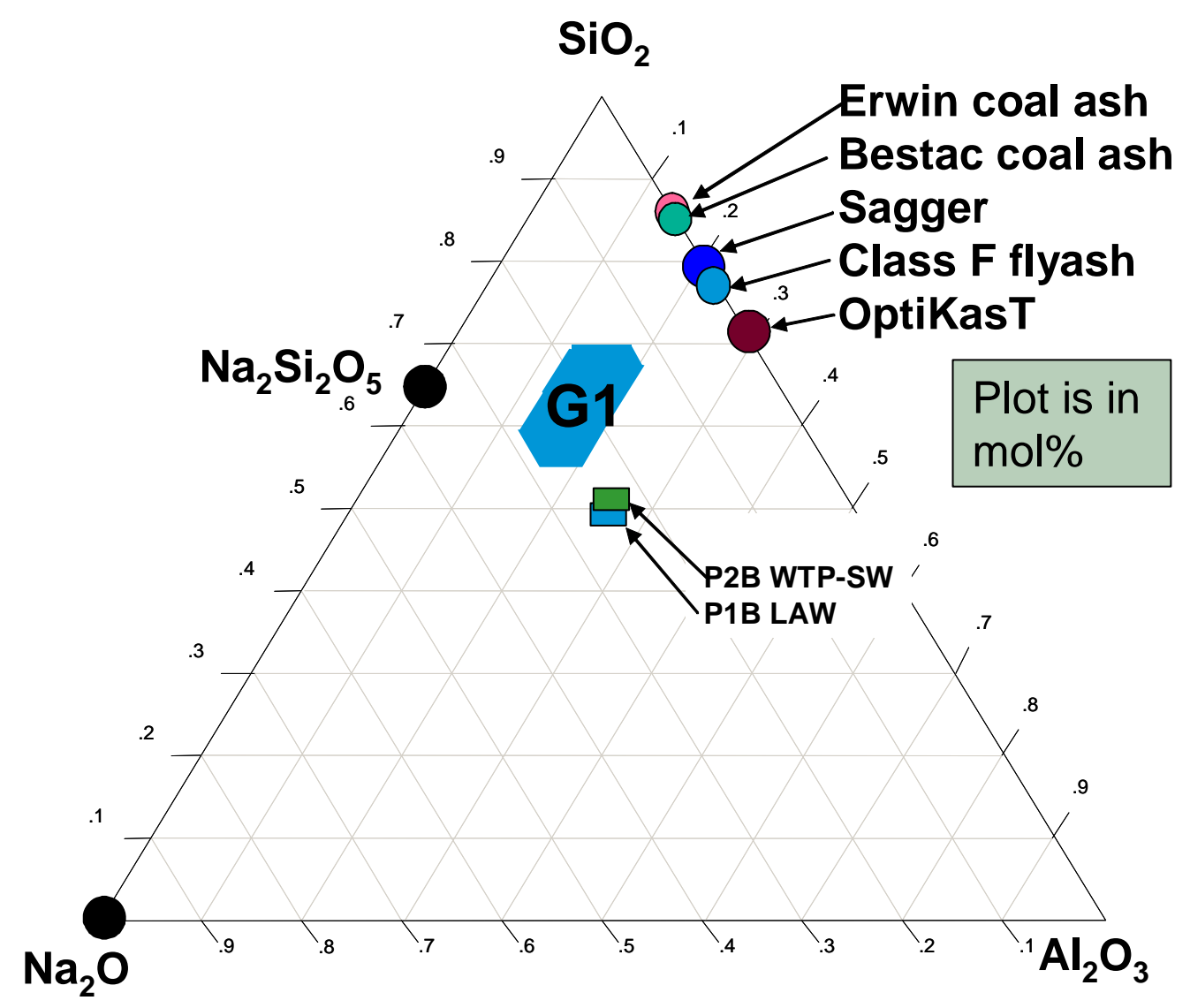

Figure 17. Ternary Phase Diagram for Geopolymer Monolith Development

Initial attempts to monolith the Fall 2009 granular product using the GEO-7 formulation with 65\% dry basis waste loading resulted in 1"x 2" cylinder monoliths made using properly sized plastic syringe tube molds with compressive strengths of only 53 to $132 \mathrm{psi}$, that did not pass 500 psi compressive strength criterion. This was likely due to extra water that had to be added to get the monoliths to form in the curing molds as shown in Table 17. The first three data columns in Table 17 show that the monoliths made with previous HRI ESTD FBSR granular product in modified centrifuge tubes produced acceptable monoliths with compressive strengths in excess of 3000 psi. Photographs of the 1" 2 " monoliths made with either HRI ESTD WTP-SW or BSR WTP-SW are shown in Figure 18. After these initial unsuccessful monolith attempts and consultation with TTT, follow on scope testing using some granular product from earlier scope-testing BSR runs indicated that longer stirring times were needed to make the GEO-7 formulation using the granular product. These latter tests produced monoliths with compressive strengths above 500 psi (590 to $1570 \mathrm{psi}$ ) as shown in the last 2 columns of BSR monolith data in Table 17. It should be noted that the crystalline phases produced in the monolith formation are similar to the starting crystalline phases of the initial BSR granular products as shown in the final data rows of Table 35 in Section 4.3.1. 


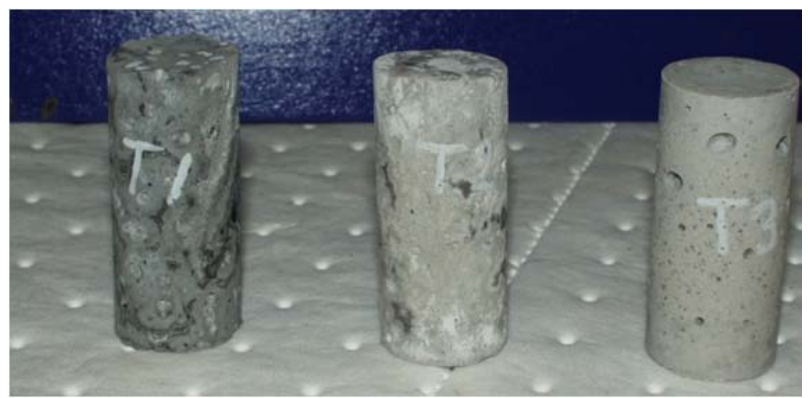

(a) 1" x 2" GEO7 monoliths made with HRI ESTD WTP-SW

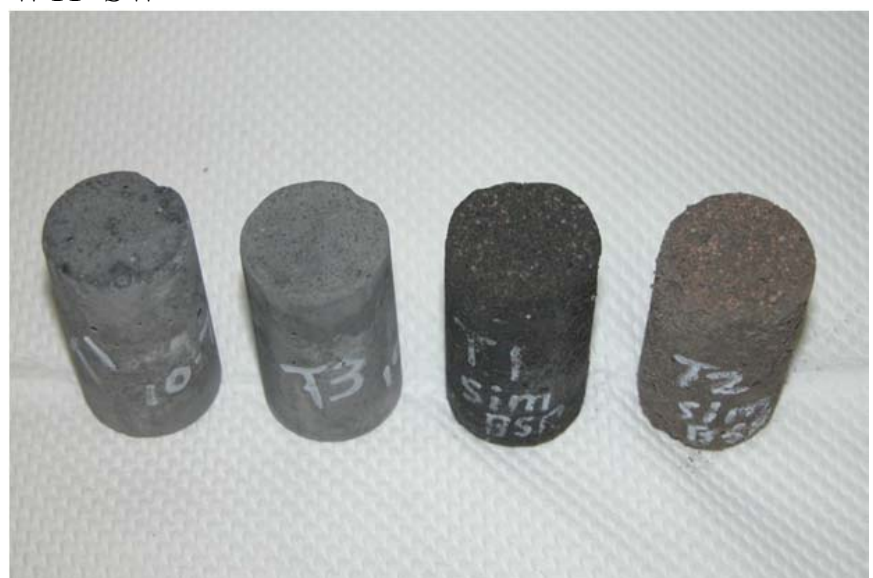

(b) 1" x 2" GEO7 monoliths made with HRI ESTD WTP-SW (2 monoliths on left) and made with SRNL BSR Simulant A (2 monoliths on right)

Figure 18. Photographs of Initial GEO7 Simulant A Monoliths 
Table 17. Data from Initial SRNL BSR Simulant A WTP SW and HRI ESTD FBSR GEO7 Monolith Efforts

\begin{tabular}{|c|c|c|c|c|c|c|c|c|c|}
\hline Mold Material & $\begin{array}{c}\text { Centrifuge } \\
\text { Tube \#1 }\end{array}$ & $\begin{array}{c}\text { Centrifuge } \\
\text { Tube \#2 }\end{array}$ & $\begin{array}{c}\text { Centrifuge } \\
\text { Tube \#3 }\end{array}$ & Syringe & Syringe & Syringe & $\begin{array}{l}\text { Syringe } \\
\text { Tube \#1 }\end{array}$ & $\begin{array}{l}\text { Syringe } \\
\text { Tube \#2 }\end{array}$ & $\begin{array}{l}\text { Syringe } \\
\text { Tube \#3 }\end{array}$ \\
\hline $\begin{array}{c}\text { Waste Mineral } \\
\text { Source: }\end{array}$ & $\begin{array}{c}\text { HRI } \\
\text { ESTD } \\
\text { WTP-SW }\end{array}$ & $\begin{array}{c}\text { HRI } \\
\text { ESTD } \\
\text { WTP-SW }\end{array}$ & $\begin{array}{c}\text { HRI } \\
\text { ESTD } \\
\text { WTP-SW }\end{array}$ & $\begin{array}{c}\text { SRNL } \\
\text { SimBSR 1 } \\
\text { WTP-SW }\end{array}$ & $\begin{array}{c}\text { SRNL } \\
\text { SimBSR } 2 \\
\text { WTP-SW }\end{array}$ & $\begin{array}{c}\text { HRI } \\
\text { ESTD } \\
\text { WTP-SW }\end{array}$ & $\begin{array}{c}\text { HRI } \\
\text { ESTD } \\
\text { WTP-SW }\end{array}$ & $\begin{array}{c}\text { SRNL } \\
\text { BSR -80 } \\
\text { mesh } \\
\text { WTP-SW }\end{array}$ & $\begin{array}{c}\text { SRNL } \\
\text { BSR } \\
\text { WTP-SW }\end{array}$ \\
\hline FBSR (g) & 30.425 & 27.377 & 27.325 & 27.381 & 27.375 & 27.381 & 27.325 & 27.31 & 27.31 \\
\hline Fly ash (g) & 8.22 & 7.395 & 7.38 & 7.383 & 7.378 & 7.395 & 7.38 & 7.38 & 7.37 \\
\hline SilicaD (g) & 11.475 & 10.351 & 10.386 & 10.312 & 10.3 & 10.304 & 10.386 & 10.42 & 10.46 \\
\hline $14 \mathrm{M} \mathrm{NaOH}(\mathrm{g})$ & 9.517 & 8.592 & 8.6 & 8.565 & 8.58 & 8.57 & 8.61 & 8.64 & 8.69 \\
\hline Total Water $(\mathrm{g})$ & 4.826 & 4.626 & 5.007 & 14.327 & 12.984 & 6.21 & 4.91 & 5.18 & 5.04 \\
\hline water: dry powder & 0.125 & 0.133 & 0.144 & 0.412 & 0.374 & 0.179 & 0.141 & 0.149 & 0.145 \\
\hline mass $(\mathrm{g})$ & 45.418 & $\mathrm{~nm}$ & 44.333 & 42.4 & 36.865 & 32.056 & 51.183 & 51.084 & 53.342 \\
\hline length (in.) & 1.875 & $\mathrm{~nm}$ & 1.875 & 2 & 1.875 & 1.406 & 2.250 & 2.250 & 2.250 \\
\hline diameter (in.) & 1 & $\mathrm{~nm}$ & 1 & 1 & 1 & 1 & 1 & 1 & 1 \\
\hline volume (in^3) & 1.472 & $\mathrm{~nm}$ & 1.472 & 1.570 & 1.472 & 1.104 & 1.766 & 1.766 & 1.766 \\
\hline volume (cc) & 24.120 & $\mathrm{~nm}$ & 24.120 & 25.728 & 24.120 & 18.090 & 28.944 & 28.944 & 28.944 \\
\hline density (g/cc) & 1.88 & $\mathrm{~nm}$ & 1.84 & 1.65 & 1.53 & 1.77 & 1.77 & 1.76 & 1.84 \\
\hline $\begin{array}{l}\text { BET surface area } \\
\left(\mathrm{m}^{2} / \mathrm{g}\right)\end{array}$ & 4.89 & 4.89 & 4.89 & 123.91 & 78.50 & 4.89 & NM & NM & NM \\
\hline LOI wt $\%$ & 11.06 & 11.06 & 11.06 & 16.3 & 10 & 11.06 & 11.06 & 10 & 10 \\
\hline Load, psi & 2618 & $\mathrm{~nm}$ & 2810 & 45 & 110 & 902 & 1137 & 506 & 1350 \\
\hline Area, sq.inch & 0.869 & $\mathrm{~nm}$ & 0.869 & 0.849 & 0.833 & 0.82 & 0.84 & 0.86 & 0.86 \\
\hline PSI & 3013 & $\mathrm{~nm}$ & 3234 & 53 & 132 & 1100 & 1350 & 590 & 1570 \\
\hline Date cast & $10 / 7 / 09$ & $10 / 7 / 09$ & $10 / 7 / 09$ & $10 / 9 / 09$ & $10 / 9 / 09$ & $10 / 9 / 09$ & $11 / 17 / 2009$ & $11 / 17 / 2009$ & $11 / 17 / 2009$ \\
\hline Date tested & $11 / 12 / 09$ & $\mathrm{~nm}$ & $11 / 12 / 09$ & $11 / 12 / 09$ & $11 / 12 / 09$ & $11 / 12 / 09$ & $12 / 9 / 2009$ & $12 / 9 / 2009$ & $12 / 9 / 2009$ \\
\hline Cure time (days) & 36 & -- & 36 & 34 & 34 & 34 & 22 & 22 & 22 \\
\hline
\end{tabular}


However, follow-on monolith activities in the Fall of 2010 using BSR WTP SW granular products again indicated that even with prolonged stirring/mixing, the mixture did not form a monolithic form using the prescribed water amounts for the GEO-7 formulation.

To better understand the sensitivity of the BSR granular product to the monolith process, two different approaches were investigated to pursue successful monolithing of the BSR granular product. One involved milling of the BSR granular product in order to produce a particle size distribution that more closely resembles that of the ESTD WTP-SW blend and LAW blend product that had been previously successfully monolithed on the various different cylinder sizes. This strategy was scope tested using some recently produced SRNL BSR product formed from non-radioactive Rassat simulant [24]. The PSD graphs shown in Figure 19 for BSR Rassat simulant, milled BSR Rassat simulant and HRI ESTD P1B LAW show how the BSR granular product can be altered so that the overall PSD is similar to the ESTD blend. Attempts to monolith the milled/altered SRNL BSR Rassat simulant granular product into the GEO-7 monolith did indeed produce 1" x 2" cylinders that passed compressive strength testing. One such trace from a milled BSR Rassat simulant GEO-7 monolith is shown in Figure 20 with a compressive strength of 1404 psi. 


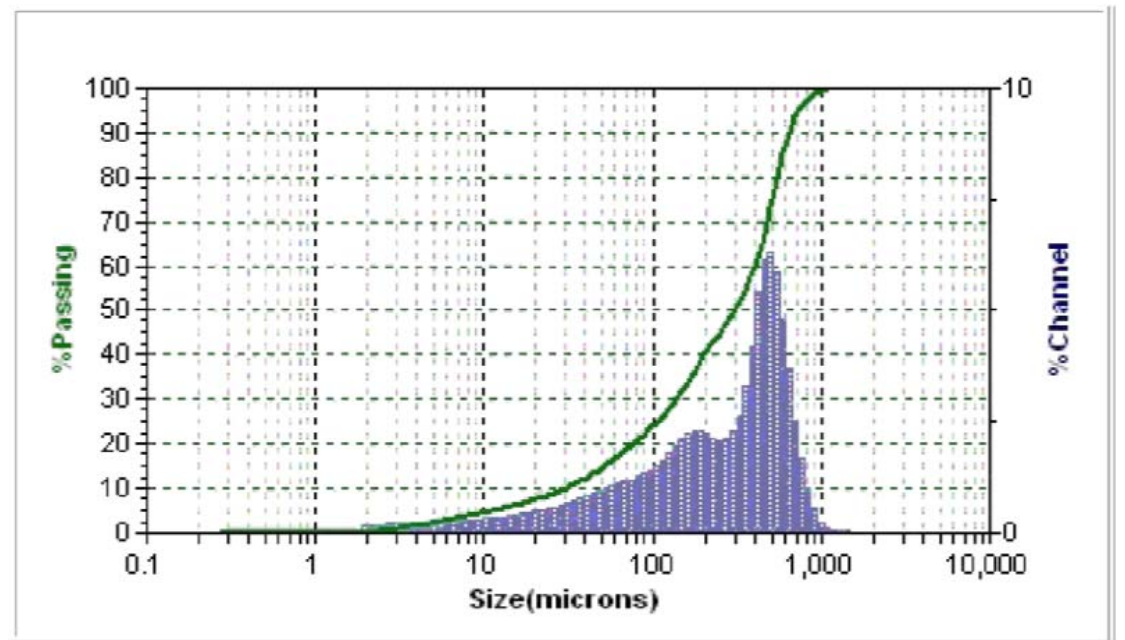

(a) BSR Simulant B after Granular Product Collection

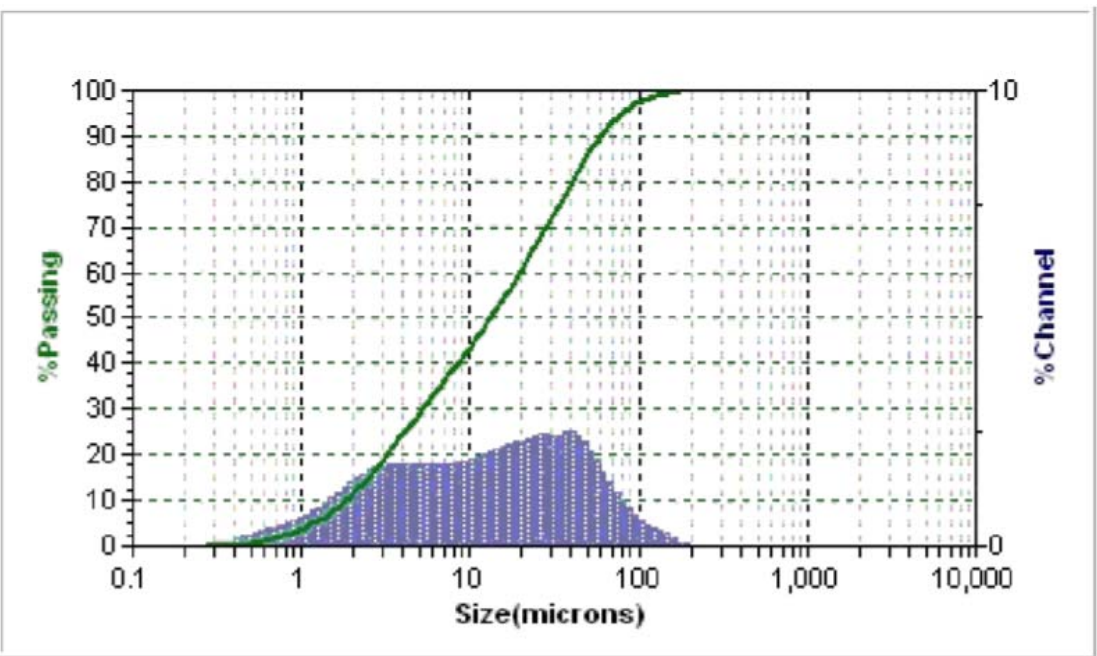

(b) Milled BSR Simulant B

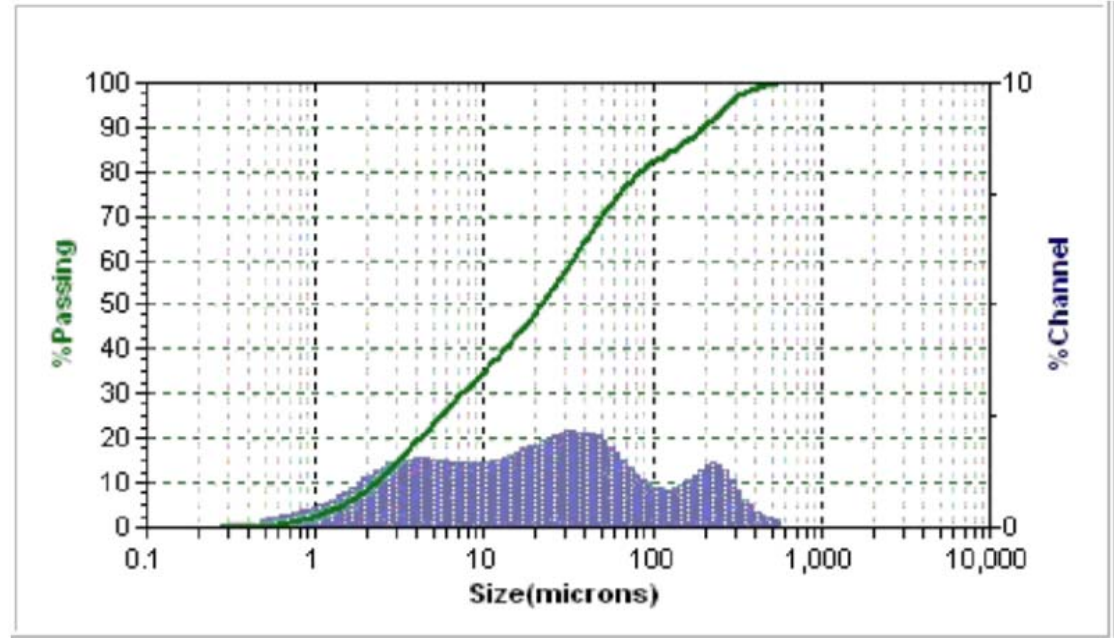

(c) HRI ESTD FBSR P1B LAW Blend Granular Product

Figure 19. Particle Size Distribution of Products 
SRNL-STI-2011-00331

Revision 0

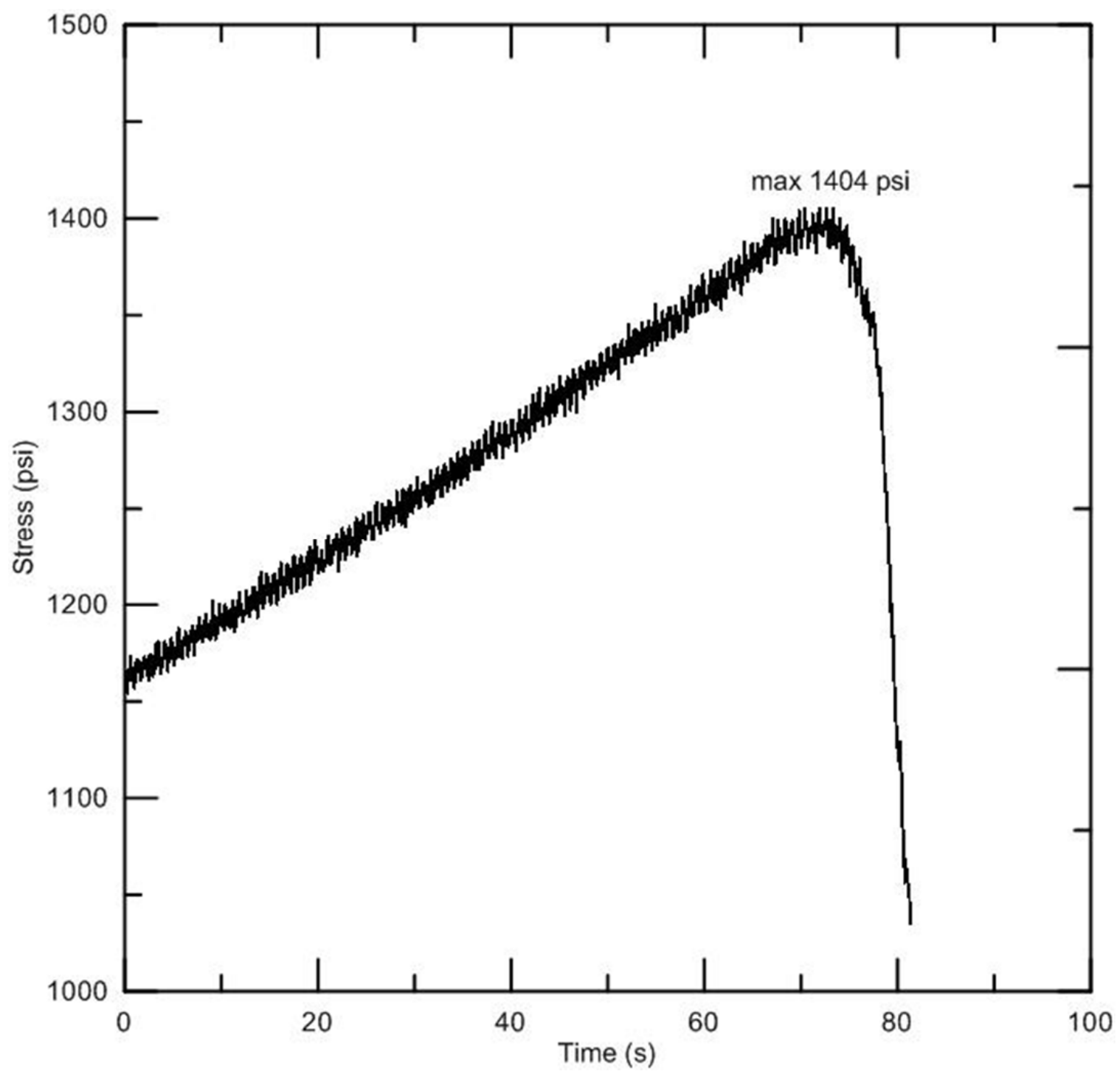

Figure 20. Compressive Strength Trace for GEO-7 Monolith Made with Milled BSR Simulant B

Another approach for successful monolithing of the BSR granular product involved going back to a claybased geopolymer monolith with lower dry-basis waste loading. Ultimately it was decided through review of past monolith testing [50] to pursue the lower waste loading 'centroid' formulation involving clay. Although this approach would use a lower waste loading than the GEO-7 recipe, it would not involve milling of the BSR granular product prior to monolithing. Table 18 shows the centroid formulation recipe giving a maximum dry basis waste loading of $42 \%$. This recipe is labeled as ' $\mathrm{T}-22-16-62-13$ ' in the manner of previous SRNL geopolymer research and it represents the molar composition of $22 \% \mathrm{Na}_{2} \mathrm{O}$, $16 \% \mathrm{Al}_{2} \mathrm{O}_{3}$ and $62 \% \mathrm{SiO}_{2}$. The last number in the label indicates a literature-based molar ratio of $\mathrm{H}_{2} \mathrm{O}$ : $\mathrm{Na}_{2} \mathrm{O}$ of 13 .

Figure 21 shows the 7-day cured compressive strength traces for four different 1" $\mathrm{x} 2$ " monoliths made with this T-22-16-62-13 recipe using SRNL BSR Simulant A (4356 psi), SRNL BSR Rassat simulant B (3300 psi), HRI ESTD P2B WTP-LAW (5844 psi) and HRI ESTD P1B LAW (4652 psi). Thus, these samples all passed the 500 psi limit by at least by $6 x(3000 \mathrm{psi} / 500 \mathrm{psi})$. 
SRNL-STI-2011-00331

Revision 0

T-22-16-62-13

$42 \%$ WL 7 day break

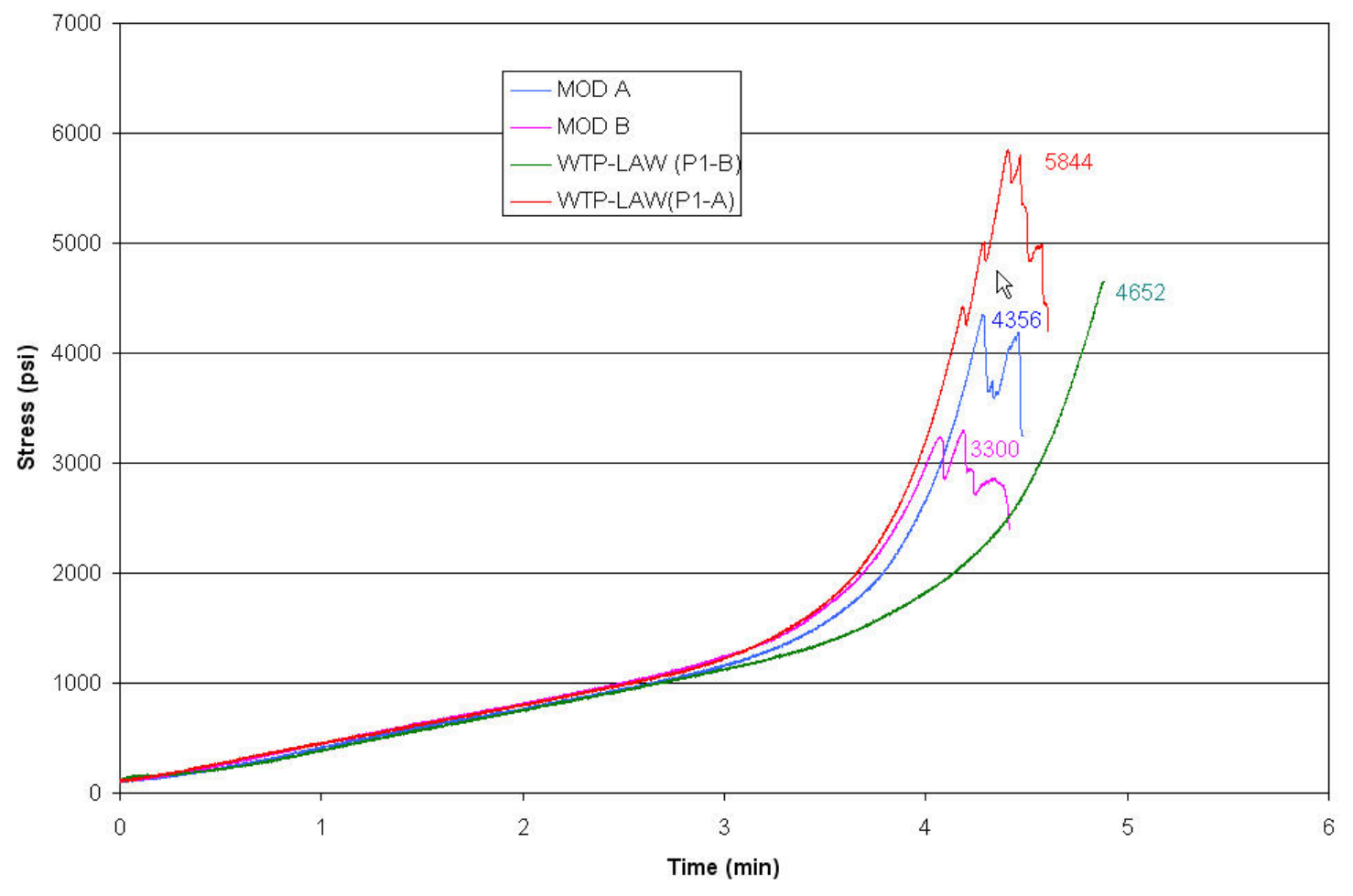

Figure 21. Compressive Strength Traces for Centroid 1" x 2" Monoliths Made with Clay

In the monolith study [22] X-ray Diffraction (XRD) and Scanning Electron Microscopy (SEM) were not part of the scope. However, during a review done by PNNL, XRD was performed and zeolite phases were found in the FBSR monoliths which are undesirable, i.e. geopolymers should remain amorphous to XRD. After the PNNL study, SRNL performed SEM on the HRI granular products and they do not contain the unreacted clay cores (see Figure 8) that the 2001 HRI samples [6] and the 2003-2004 STAR [16] samples had. This was attributed to design and process improvements that were made by TTT/HRI since 2006 which have increased bed reactivity. This means that the clay cores in the FBSR product were unavailable to participate in the geopolymerization which altered the geopolymer formulations to be outside the region G1 targeted. The path forward determined in reference 50 was two-fold. Formulations made with fly ash would be made with less $\mathrm{NaOH}$ and in the G1 region and/or formulations should be made with the reactive clay rather than fly ash. Two reasons for preferring kaolin over fly ash are (1) the unreactive nature of some of the components found in fly ash, e.g. the minerals mullite and quartz, and (2) the variable nature of fly ash compositions from various coal production facilities. Accordingly, it was decided to switch geopolymer binder components from the fly ash to the heat-treated clay and to use less sodium hydroxide solution to attain a binder composition in the center of the G1 centroid.

Initial monolith attempts used the sequencing from previous studies that involved pre mixing of the dry powders (BSR granular product and fly ash) followed by addition of the liquids sodium silicate, sodium hydroxide and water. Latter formulations involving clay used a different strategy of premixing the liquids, then blending in the dry clay powders to get a smooth consistent 'slurry'. To this slurry, the final dry BSR granular powders were then added with final mixing. 
All of the 1" x 2" cylinders formulated in this testing used a Kitchen Aid mixer fitted with a flat beater multipurpose agitator. All cylinder monoliths made in this project used standard plastic molds with fitted plastic caps. No heat treatment was applied to any of the monoliths fabricated in this project.

Table 18. Centroid Geopolymer WTP SW Simulant Monolith Recipe Made with Clay

\begin{tabular}{|l|l|}
\hline \multicolumn{1}{|c|}{ T-22-16-62-13 } & \multicolumn{1}{c|}{ grams } \\
\hline Silica $\mathrm{D}\left(44.1 \mathrm{wt} \% \mathrm{Na}_{2} \mathrm{O} \bullet \mathrm{SiO}_{2}\right)$ & 23.8 \\
\hline Caustic $(50 \mathrm{wt} \% \mathrm{NaOH})$ & 10.8 \\
\hline Water $\left(\mathrm{H}_{2} \mathrm{O}\right)$ & 10.1 \\
\hline Helmer Kaolin $\left(\mathrm{HT} @ 650^{\circ} \mathrm{C}\right)$ & 24.4 \\
\hline (F)BSR WTP SW & 28.2 \\
\hline Total Mass & 97.3 \\
\hline Calculated $\mathrm{Wt} \% \mathrm{H}_{2} \mathrm{O}$ & $31.4 \mathrm{wt} \%$ \\
\hline
\end{tabular}

After successful monolith fabrication with the simulant WTP SW granular product using the centroid clay geopolymer at $42 \mathrm{wt} \%$ dry basis waste loading, several scoping runs were performed in preparation for forming the radioactive WTP SW monolith with granular product using remote handling and mixing.

A similar centroid clay-based monolith recipe shown in Table 19 with the same $\mathrm{Na}_{2} \mathrm{O} / \mathrm{Al}_{2} \mathrm{O}_{3} / \mathrm{SiO}_{2}$ ratio of 22/16/62 was used for the radioactive monolith with a slightly higher water content of $13.5 \mathrm{H}_{2} \mathrm{O} / \mathrm{Na}_{2} \mathrm{O}$ (vs. $13.0 \mathrm{H}_{2} \mathrm{O} / \mathrm{Na}_{2} \mathrm{O}$ used with WTP SW simulant monolith). This very small increase in water was selected to account for the slightly longer times required for mixing and transfer of the monolith precursor into the curing mold using remote handling. It should be noted here that while prolonged mixing of BSR granular product could indeed help the GEO-7 formulation, we also found with experience that too much mixing time with the BSR granular product and the centroid clay geopolymer could result in a mixture that could not be transferred to a curing mold. In other words the geopolymer formation reactions seem to initiate within several minutes of full mixing, potentially causing the entire mixture to set up in the mixer bowl before one is able to properly transfer to a curing mold.

Table 19. Centroid Geopolymer Radioactive WTP SW Monolith Recipe Made with Clay

\begin{tabular}{|l|l|}
\hline \multicolumn{1}{|c|}{ T-22-16-62-13.5 } & \multicolumn{1}{c|}{ grams } \\
\hline Silica $\mathrm{D}\left(44.1 \mathrm{wt} \% \mathrm{Na}_{2} \mathrm{O} \bullet \mathrm{SiO}_{2}\right)$ & 26.3 \\
\hline Caustic $(50 \mathrm{wt} \% \mathrm{NaOH})$ & 11.9 \\
\hline Water $\left(\mathrm{H}_{2} \mathrm{O}\right)$ & 11.5 \\
\hline Helmer Kaolin $\left(\mathrm{HT} @ 650^{\circ} \mathrm{C}\right)$ & 26.9 \\
\hline (F)BSR Rad WTP SW & 31.2 \\
\hline Total Mass & 97.3 \\
\hline Calculated $\mathrm{Wt}^{2} \mathrm{H}_{2} \mathrm{O}$ & $31.7 \mathrm{wt} \%$ \\
\hline
\end{tabular}

Subsequently, triplicate BSR WTP SW 1"x 2" monolith cylinders made with the centroid clay formulation and the WTP SW granular product from Spring 2011 were prepared and one was compression tested. The crushed monolith was then used for all subsequent testing including chemical composition, PCT and TCLP. A single 1" x 2" cylinder was made with the radioactive BSR WTP SW 
granular product along with a smaller 0.5 " x 1 " 'button'. The radioactive 1 " x 2 " monolith was compression tested and the crushed monolith was then used for subsequent testing including chemical composition, PCT and TCLP. The radioactive button was used for monolith leach testing.

\subsection{Compressive Strength Test}

All the cylinders were compression tested using ASTM C39-04A. These compression testing procedures and instruments were the same as used in previous SRNL studies on monoliths made using FBSR products $[14,22]$. Initial monolith compression testing on the GEO-7 monoliths prepared in Fall 2009 was performed at the SRS by William L. Myhre of the United Research Services (URS) Company in the SRS N-Area Civil Engineering Test Facility. All subsequent monolith compression testing (from 2010 to date) used similar instrumentation that had been set up within SRNL. SRNL used a Humboldt Manufacturing model HCM-3000-LXI compression tester. The samples were tested using a modified version of the 2010 reissue of ASTM C 39/C39M [51] to accommodate the sample size. Samples were tested with unbonded caps using ASTM C 1231 [52] modified to accommodate the sample size and lower limit of compressive strength. Compression testing of the radioactive monolith was performed by identical equipment using the same methodology in a double plastic bag during testing to prevent contamination of the instrument and lab.

\subsection{Durability Testing}

\subsubsection{Product Consistency Test}

The chemical durability of the BSR products and monoliths were determined using the Product Consistency Test (PCT) ASTM procedure C 1285-08 [53]. The BSR granular product and monolith product samples were sized between (-) 100 and (+) 200 mesh $(<149 \mu \mathrm{m}$ and $>74 \mu \mathrm{m})$, which is the same size fraction used to express glass waste form performance. No attempts were made to measure the XRD of the sized granular product to confirm that the relative crystalline species seen in the as-received BSR product were the same after size reduction. The granular products (simulant and radioactive) were not put through a grinder, but rather wet sieved using an automatic sieve shaker device. The monolith pieces resulting from post compression test crushing were initially size reduced by brief grinding in a tungsten blade grinder with steel cup. The sized material was washed six times ( 2 with rinse/decant, and 4 with rinse/sonication/decant) with $100 \%$ ethanol to remove electrostatic fines, followed by overnight drying in an oven at $90^{\circ} \mathrm{C}$. Water was not used for washing to minimize the potential for water soluble phases being removed prior to leaching as cautioned by the ASTM C1285-08 procedure. No analyses were performed on the ethanol rinses to determine if any elements contained in the FBSR minerals or monoliths were solubilized in the rinse ethanol. Portions of the washed and dried BSR granular product or monolith powders were analyzed using Microtrac - 53500 (nonradioactive samples) and X-100 (radioactive samples) instrumentation for particle size analysis by laser light scattering. BrunauerEmmett-Teller - Surface Area (BET SA) measurements via nitrogen gas adsorption was also performed on the sieved/washed/dried portions of the powders used for PCT. The PCT durability testing was performed on non-roasted samples for all tests in this project, i.e., samples that contained residual BSR coal. The BET SA was performed on a non-roasted PCT sample for the initial Fall 2009 simulant A granular product; however, all subsequent BET SA measurements (radioactive A granular product, simulant A monolith and radioactive A monolith) were performed on roasted powders. Standard glass samples were included in all the PCTs to monitor PCT performance vs. past historical data for the ARM [54] and Low activity Reference Material [55] glasses. PCT data for these glasses is shown along with the expected ranges of leachate concentrations in Appendix A. 
Both a low and high surface area standard were typically run in parallel for the BET surface area instrument. The low SA standard used NIST-traceable silicon nitride powder with a certified $2.05 \pm 0.09$ $\mathrm{m}^{2} / \mathrm{g}$ SA. The high SA standard used silica - alumina from Micromeritics with a certified $214 \pm 6 \mathrm{~m}^{2} / \mathrm{g}$ SA. The uncertainties in the BET SA of the standards are about 3\% (\%RSD), which is similar to previously reported uncertainties in the BET SA measurements of primary silicate minerals of about $\pm 5 \%$ for measured surface areas $>0.1 \mathrm{~m}^{2} / \mathrm{g}$ [56]. For all samples, ASTM Type I water was used as the leachant, a constant leachate to sample mass ratio of $10 \mathrm{~cm}^{3} / \mathrm{g}$ was used, the test temperature was $90^{\circ} \mathrm{C}$, and the test duration was seven days. As mentioned above the test 'samples' consisted of either granular product or monolith that all included residual amounts of coal from the BSR process. Test duration and temperature are the nominal test conditions used for testing glass waste form performance under the PCT-A.

The PCT results can be expressed per ASTM C-1285-08 as a normalized concentration $\left(\mathrm{NC}_{\mathrm{i}}\right)$ which have units of $g_{\text {waste form }} / \mathrm{L}_{\text {leachant }}$, or as a normalized release $\left(\mathrm{NL}_{\mathrm{i}}\right)$ in $\mathrm{g}_{\text {waste form }} / \mathrm{m}^{2}$. Examples of the calculations are given in Equations 1 and 2.

$$
N C_{i}=\frac{C_{i}(\text { sample })}{f_{i}}
$$

where $\quad \mathrm{NC}_{\mathrm{i}}=$ normalized concentration ( $\mathrm{g}_{\mathrm{waste}}$ form $/$ Lleachant $)$

$c_{i}($ sample $)=$ concentration of element " $i$ " in the solution $\left(\mathrm{g}_{\mathrm{i}} / \mathrm{L}\right)$

$\mathrm{f}_{\mathrm{i}}=$ fraction of element " $\mathrm{i}$ " in the unleached waste form

$$
\left.N L_{i}=\frac{c_{i}(\text { sample })}{\left(f_{i}\right) \bullet(S A / V)} \quad \text { (Equation }\right)
$$

where $\quad \mathrm{NL}_{\mathrm{i}}=$ normalized release $\left(\mathrm{g}_{\text {waste }}\right.$ form $\left./ \mathrm{m}^{2}\right)$

$c_{i}($ sample $)=$ concentration of element " $i$ " in the solution $\left(g_{i} / L\right)$

$f_{i}=$ fraction of element " $i$ " in the unleached waste form

$\mathrm{SA} / \mathrm{V}=$ surface area of the waste form divided by the leachate volume in $\mathrm{m}^{2} / \mathrm{L}$

Due to the high surface roughness of ceramic/mineral waste forms such as FBSR the method for SA/V determination for this work involves a measurement of the surface area by the BET method. In this method, the amount of an inert gas that condenses on a powdered sample of known mass is measured at a temperature near the boiling point of the gas. The amount of gas condensed on the sample is measured by the pressure change in the system upon exposure to the sample. This method measures all open pores, inclusions, irregularities, etc. that are penetrable by the inert gas. The SA/V ratio is calculated by dividing the measured BET surface area/ gram powder, by the leachant volume via Equation 3.

$\mathrm{SA} / \mathrm{V}_{\mathrm{BET}}=\left(\mathrm{SA}_{\mathrm{BET}} /\right.$ gram sample $) /($ gram sample $/ \mathrm{V}) \quad$ (Equation 3$)$

Due to the presence of coal in the sample, several adjustments have to be made in these equations to express the leaching of a particular element on a coal free basis as described in Pareizs et al. [10] This is done because the coal does not contain any of the constituents of concern (COC) structurally as a separate mineral phase and so it is considered a diulent in the sample when it cannot be removed manually. First, the $\mathrm{f}_{\mathrm{i}}$ term in Equation 1 and 2 must be expressed on a coal free basis. The sample is sent for dissolution and analysis with the coal content in it. Moisture is measured as LOD at $110^{\circ} \mathrm{C}$ and the coal as LOI at 
$525^{\circ} \mathrm{C}$. The elementals are converted to an oxide basis and mass balanced with the LOD and LOI. The sums should be within $100 \pm 5 \%$, which ensures that the chemical analyses mass balance. Coal also contributes to the BET surface area as shown in Pareizs et al. [10] and would cause an abnormally high BET surface area in the denominator of Equation 2. Therefore, a subset of the PCT prepared sample sieved to -100 to +200 and ethanol washed is roasted at $525^{\circ} \mathrm{C}$ to get a 'coal free' BET surface area but this subset is not used in the leach testing.

\subsubsection{Accelerated Leach Test}

The radioactive monolith was leach tested using the ASTM 1308 'Standard Test Method for Accelerated Leach Test for Diffusive Releases from Solidified Waste'. This test is similar to the ANS 16.1 Leach Test. The semi-dynamic test uses successive batch contacts with ASTM-I water per Figure 22. The liquid to solid ratio is $10 \mathrm{X}$ volume $(\mathrm{mL})$ to monolith surface area $\left(\mathrm{cm}^{2}\right)$, giving a $127 \mathrm{~mL}$ leachant volume required for the 0.5 " x 1 " cylinder (total of $12.7 \mathrm{~cm}^{2}$ surface area). Leaching intervals consist of 2 hours, 5 hours, 17 hours, and 24 hours, and then daily for the next 10 days. An additional leaching interval of nineteen days is also included in this work. The specimen is suspended from the top of the polybottle container lid and the specimen support contacts no more than $1 \%$ of the surface area so as to not impede leaching. Leachate concentrations are converted to cumulative amounts of constituents leached using the leachate volume and mass of monolith and measured elemental compositions.

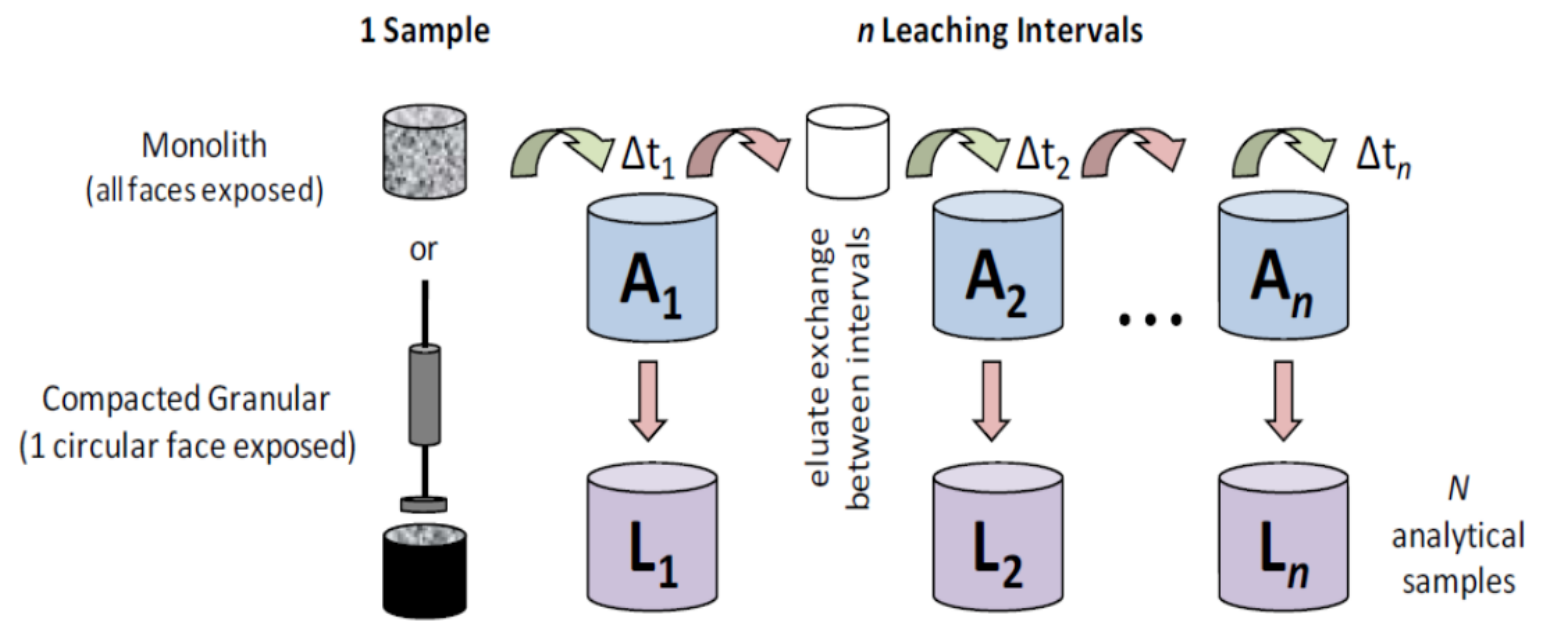

Figure 22. Schematic of the Semi-dynamic Monolith Leach Test 
SRNL-STI-2011-00331

Revision 0

The observed diffusivity for each constituent is calculated using the analytical solution, Equation 4, for simple radial diffusion from a cylinder into an infinite bath as presented by Crank [57].

$$
\mathrm{D}_{i}=\left[\mathrm{M}_{t i} /\left(2 \rho \mathrm{C}_{\mathrm{o}}\left(\mathrm{t}_{\mathrm{i}}{ }^{1 / 2}-\mathrm{t}_{\mathrm{i}-1}{ }^{1 / 2}\right)\right)\right]^{2}
$$

where

$$
\begin{aligned}
& \text { Di = observed diffusivity of a specific constituent for leaching } \\
& \text { interval, } i\left[\mathrm{~m}^{2} / \mathrm{s}\right] \\
& \mathrm{M}_{t i}=\text { mass released during leaching interval } i\left[\mathrm{mg} / \mathrm{m}^{2}\right] \\
& \mathrm{t}_{\mathrm{i}}=\text { cumulative contact time after leaching interval, } i[\mathrm{~s}] \\
& \mathrm{t}_{\mathrm{i}-1}=\text { cumulative contact time after leaching interval, } i-1[\mathrm{~s}] \\
& \mathrm{C}_{\mathrm{o}}=\text { initial leachable content }[\mathrm{mg} / \mathrm{Kg}] \\
& \rho=\text { sample density }\left[\mathrm{kg}-\mathrm{dry} / \mathrm{m}^{3}\right] \text {. }
\end{aligned}
$$

The mean observed diffusivity for each constituent can be determined by taking the average of the interval-observed diffusivity with the standard deviation.

The leach index (LI), the parameter derived directly from immersion test results, evaluates diffusioncontrolled contaminant release with respect to time. The LI is used as a criterion to assess whether solidified/stabilized waste will likely be acceptable for subsurface disposal in waste repositories. In most cases, the solidified waste is considered effectively treated when the LI value is equal to or greater than 9. The LI is calculated with Equation 5.

$$
\mathrm{LI}=-\log \left[D_{n} / \mathrm{cm}^{2} / \mathrm{s}\right] \quad \text { (Equation 5) }
$$

where $L I$ is the leach index, and $D_{n}$ is the effective diffusivity for elements of interest $\left(\mathrm{cm}_{2} / \mathrm{s}\right)$ during the leach interval $n$.

\subsubsection{TCLP}

The Hanford LAW is a listed waste under the EPA RCRA. When treated, the waste form must retain the hazardous components at the Universal Treatment Standard (UTS) limits [58]. The Land Disposal Restrictions (LDRs) will apply to shallow land burial at Hanford.

All blended aggregate samples and crushed monoliths were evaluated for retention of the hazardous metals by the EPA Toxicity Characteristic Leaching Procedure, Method 1311 (TCLP) [59]. The TCLP method prescribes a $100 \mathrm{~g}$ sample sized to $<9.5 \mathrm{~mm}$ to $20 \mathrm{X}$ leachate ratio. However, in this program the amount of either BSR granular product or monolith was very limited. Accordingly on 10-25 gram simulant samples and 3 to 6 gram radioactive samples were submitted to GEL Laboratories, LLC of Charleston, SC, an EPA-certified laboratory. In the standard leaching procedure, $100 \mathrm{~g}$ samples of $<9.5$ $\mathrm{mm}$ diameter are extracted by a buffered acetic acid fluid for 18 hours. The extraction fluid (leachate) is then filtered and analyzed for elements of interest. A schematic for the TCLP is shown in Figure 23. 
SRNL-STI-2011-00331

Revision 0

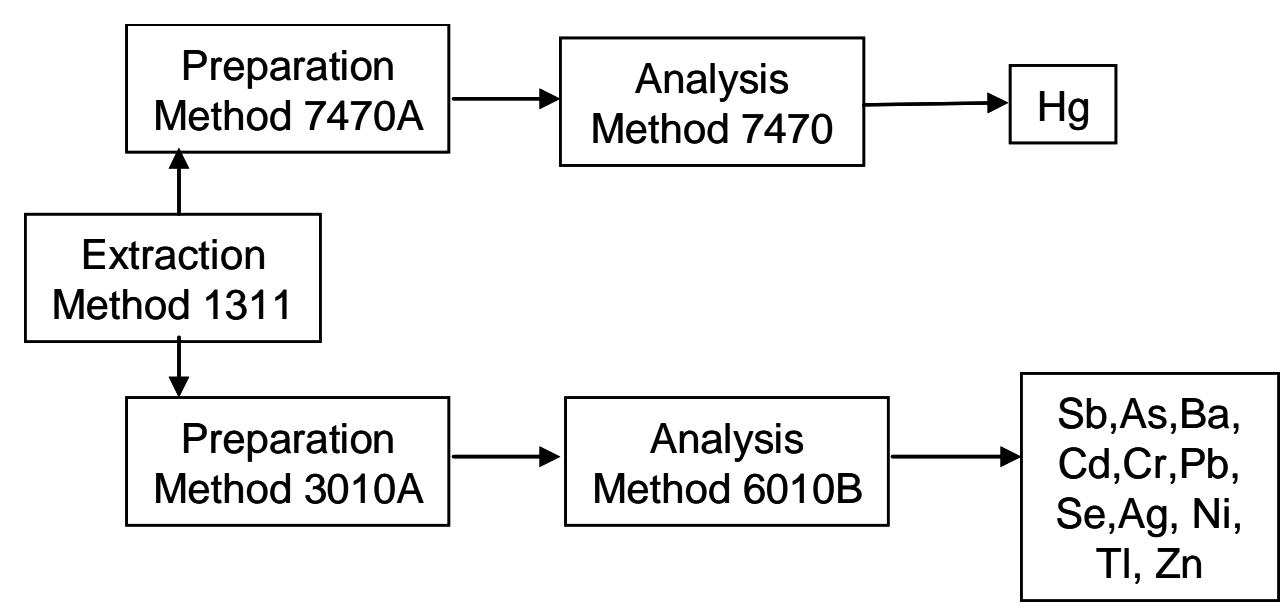

Figure 23. Schematic of the TCLP

Since organics are destroyed in the FBSR process, only the following RCRA hazardous inorganic species were measured: $\mathrm{As}, \mathrm{Ba}, \mathrm{Cd}, \mathrm{Cr}, \mathrm{Pb}, \mathrm{Se}, \mathrm{Ag}, \mathrm{Ni}, \mathrm{Sb}, \mathrm{Tl}$ and $\mathrm{Zn}$. If the concentration of a hazardous inorganic species from the simulated waste form is higher than the UTS limits, then it is assumed that a real waste treated in a similar manner would fail the UTS limits and require further remediation. Simulant and radioactive BSR granular products and monoliths were submitted for TCLP analyses. It is important to note that all TCLP testing in this program used 'as-received' materials, i.e., none of the materials submitted for TCLP were heat-treated to remove carbon. Since TCLP results are reported on a ' $\mathrm{mg} / \mathrm{L}$ ' basis for comparison to the UTS limits, no normalization of the TCLP leachate data was performed, i.e., normalization similar to what is performed for PCT using elemental fractions and measured surface areas. There can be excessive variability in data derived from TCLP testing due to the lack of any specification in lower particle sizes used in this test, i.e., particles can range from $<9.5 \mathrm{~mm}$ down to any potential size including submicron sizes. 
SRNL-STI-2011-00331

Revision 0

\subsection{Results and Discussion}

\subsection{BSR Operational Results}

\subsubsection{Fall 2009 Campaign}

For this set of runs, coal was fed at a rate of $0.20 \mathrm{~g} / \mathrm{min}$. Total gas flow was as high as reasonable, but limited based on observed solids carry over. The DMR temperatures were controlled within the target range for the runs. All operational conditions were approved by TTT as stated in various e-mails which are documented in the lab notebook SRNL-NB-2009-00115.

The placement of the thermocouples in the DMR changed and the choice of the controlling thermocouple changed over the course of the six runs performed. During the 8/26/09 and 9/02/09 runs with nonradioactive feed, the controlling thermocouple was 1 inch into the beads and the upper thermocouple was positioned 4 inches above the beads. During the 9/08/09 run with non-radioactive feed, the controlling thermocouple was level with the bead surface and the upper thermocouple was positioned 4 inches above the beads. This configuration was very uncontrollable due to the water and steam from the slurry making contact with the controlling thermocouple. During the 9/10/09 run with non-radioactive feed, the controlling thermocouple was 4 inches above the beads and the lower thermocouple was at the bead surface. This configuration required too much temperature span to stay within the desired limits. During the $9 / 15 / 09$ and 9/17/09 runs with non-radioactive feed, the controlling thermocouple was $2 \frac{1}{2}$ inches above the beads and the lower thermocouple was at the bead surface. This configuration proved better than the initial configuration and was thus used from the $9 / 15 / 09$ to $9 / 17 / 09$ time forward.

Off-gas conditioning went through configuration changes during the period of these six runs. Off-gas conditioning was performed to protect the mass spectrometer, which measured the off gas downstream. During the 8/26/09 and 9/02/09 runs, the gases leaving the condenser bubbler were treated by a dry ice condenser, which removed about $8 \mathrm{~mL}$ of water per run. During the 9/08/09 run, a 50 micron filter was added after the dry ice condenser, but did not show any sign of smoke particle build-up. During the 9/10/09 run, a 25 micron filter followed by a 2 micron filter was added after the dry ice condenser and the 25 micron filter turned dark brown after one run where there was no sign of color change on the 2 micron filter downstream. During the 9/15/09 and 9/17/09 runs, the gases leaving the condenser bubbler were treated by a standard secondary condenser which collected about $5 \mathrm{~g}$ water per run followed by a 25 micron filter and then a 2 micron filter. This configuration was judged optimal and has remained unchanged.

The actual measured REDOX and LOI results for the six 2009 campaign runs are shown in Table 20. Notice in the table that the product LOI, which is the measure of unreacted coal in the product, was high for the first three runs by being above $12 \%$. The 9/10/09 and 9/15/09 runs were considered on target and the $9 / 17 / 09$ run was considered low $(<10 \%)$. The desired range for the LOI came from the measured values of the FBSR product these runs were to replicate. To help lower the LOI, the DMR was operated longer after the feeding was completed. To complement this effort, the coal was reduced from $0.2 \mathrm{~g} / \mathrm{min}$ to $0.16 \mathrm{~g} / \mathrm{min}$ for the last two runs. The product REDOX was targeted between 0.72 and 0.92 based on the measured values of the FBSR product these runs were to replicate. The measured REDOX was high for all runs except the 9/10/09 and 9/17/09 runs. It was discovered at this time that high unreacted coal concentrations $(>10 \mathrm{wt} \%)$ in the product caused the REDOX measurements, which are performed by colorimetry, to read higher than the actual REDOX of the product once the unreacted coal is removed from the product. This discovery led to targeting a much lower LOI in all future runs. 
Table 20. BSR REDOX and LOI Results for Original Simulant Runs Fall 2009

\begin{tabular}{|l|c|c|c|c|c|c|}
\hline \multicolumn{1}{|c|}{ RUN DATE } & $\mathbf{8 / 2 6 / 0 9}$ & $\mathbf{9 / 0 2 / 0 9}$ & $\mathbf{9 / 0 8 / 0 9}$ & $\mathbf{9 / 1 0 / 0 9}$ & $\mathbf{9 / 1 5 / 0 9}$ & $\mathbf{9 / 1 7 / 0 9}$ \\
\hline $\begin{array}{l}\text { Product } \\
\text { REDOX } \\
\text { Target } \\
\mathbf{( 0 . 7 2 - 0 . 9 2 )}\end{array}$ & $0.91 / 0.97$ & $0.98 / 0.95$ & $0.98 / 0.98$ & $0.90 / 0.89$ & $0.96 / 0.95$ & $0.87 / 0.87$ \\
\hline $\begin{array}{l}\text { Product LOI } \\
\text { Target } \\
(\mathbf{1 0 - 1 2} \%)\end{array}$ & 16.4 & 17.1 & 15.5 & 10.7 & 10.3 & 7.9 \\
\hline \begin{tabular}{l} 
Combined Runs \\
\hline
\end{tabular} & \multicolumn{2}{|c|}{ These three runs combined into Simulant 1 } \\
composite
\end{tabular}

The actual BSR process operating conditions for the six 2009 campaign runs are shown in Table 21. Due to a desire to lower the LOI, attempts were made to operate the DMR longer after the feeding was completed after the initial runs. To complement this effort, the coal was reduced from $0.2 \mathrm{~g} / \mathrm{min}$ to 0.16 $\mathrm{g} / \mathrm{min}$ for the last two runs (with TTT approval).

The product REDOX was targeted between 0.72 and 0.92 based on the measured values of the FBSR product these runs were to replicate.

The products from the first three WTP SW simulant runs $(8 / 26 / 09,9 / 2 / 09$, and 9/8/09) and the products from the second three simulant runs $(9 / 10 / 09,9 / 15 / 09$, and 9/17/09) were combined into two different WTP SW composites, designated as Simulant 1 and Simulant 2, respectively. These two separate composites were analyzed for chemical composition and durability as described later in this report.

As discussed earlier, the thermocouple location was moved throughout the simulant testing in an attempt to optimize processing. As a result of this, the process trends look very different. Therefore, only the last run of 9/17/09 is shown in the body of this text. The process trends for all of the Fall 2009 campaigns are shown in Appendix B.

Note on the 9/17/09 temperature trend, Figure 24 , where the bed temperature quickly rises from $700^{\circ} \mathrm{C}$ to $725^{\circ} \mathrm{C}$, with an immediate fall back to $\sim 700^{\circ} \mathrm{C}$. This typically happens because the control system cannot offset the loss of cooling that occurs when the feed slurry is stopped. Notice that the control temperature 2 $1 / 2$ inches above the bed was dropped from $700^{\circ} \mathrm{C}$ to $680^{\circ} \mathrm{C}$ to offset the loss of cooling. Since this very brief temperature increase with prompt return to $700^{\circ} \mathrm{C}$ is so small in relative time duration compared to the overall feeding and post-feed time durations, it is not expected to significantly affect any of the BSR product properties. In later campaigns, the control temperature was lowered just before the feed was to be shut off to reduce the amount of temperature rise. The process off-gas trend for this run is provided in Figure 25. It should be noted that all temperature trend graphs and off-gas trend graphs in this report use the X-axis in units of 'minutes'.

Quite a noticeable amount of solids from process carryover were collected in the condenser bubbler during these runs, which led to the future use of quartz wool in the crossover tube along with some other process changes. 


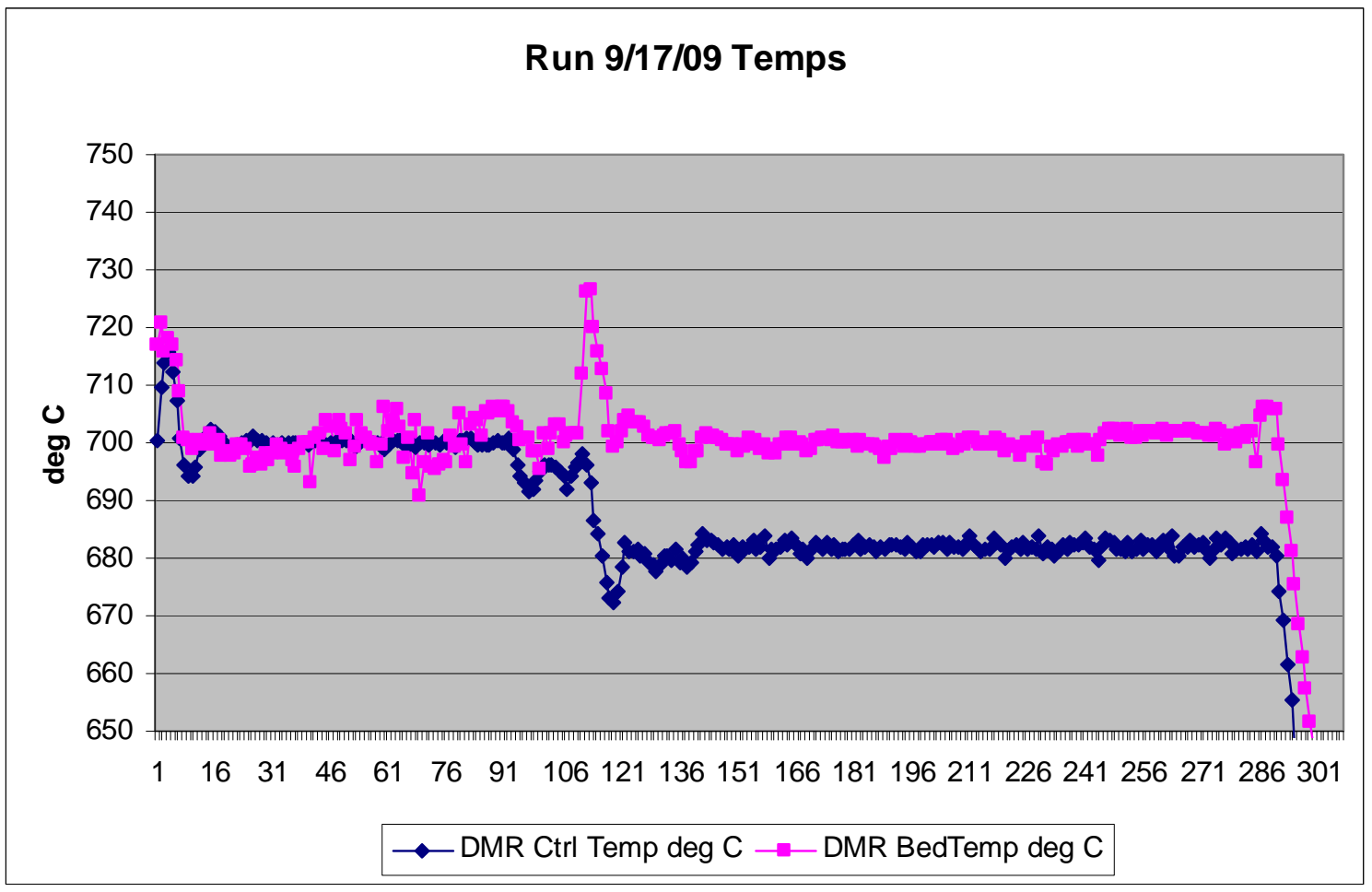

Figure 24. Run 9/17/09 Temperatures in DMR

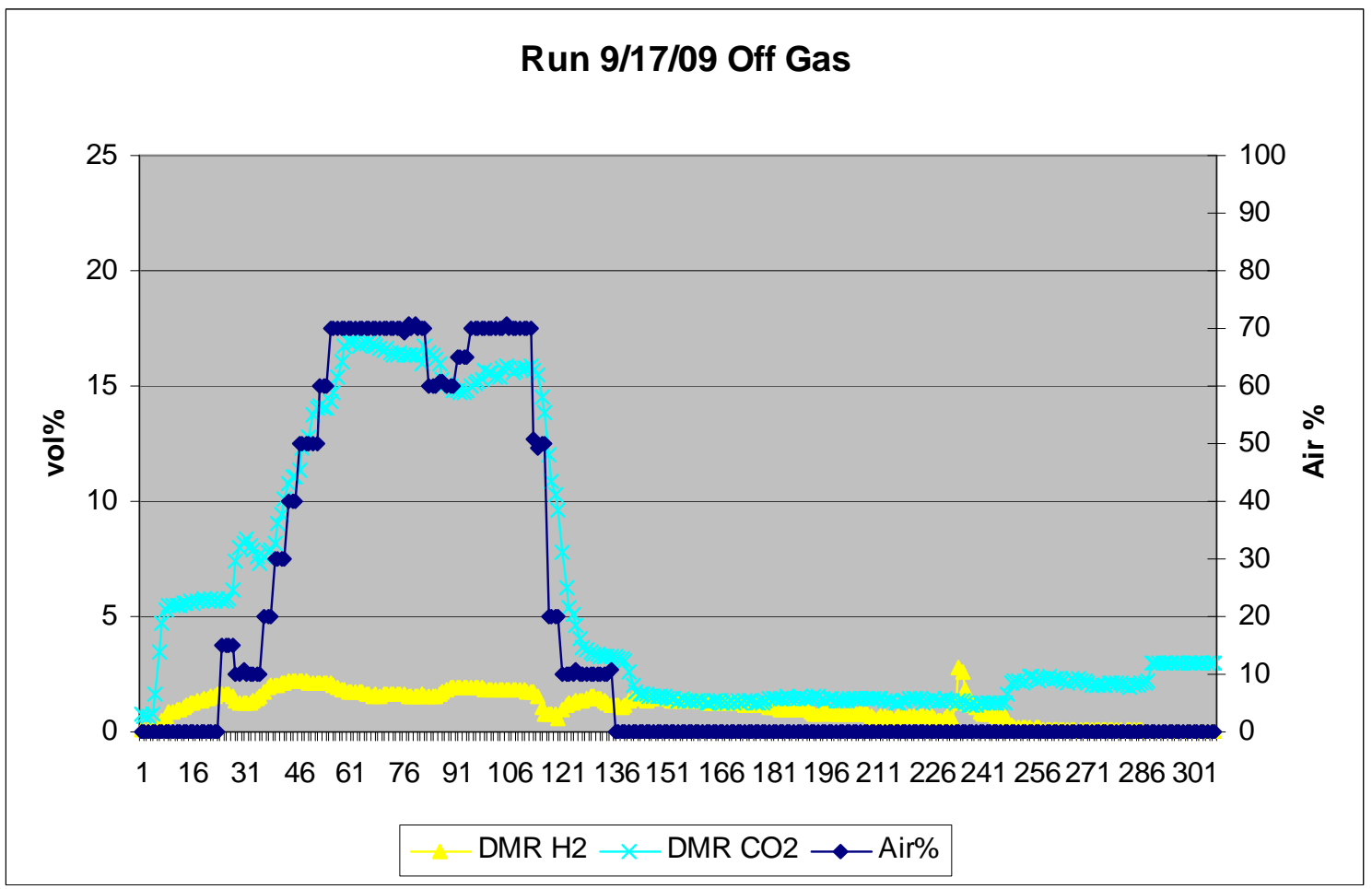

Figure 25. Run 9/17/09 Off Gas Concentrations and Air\% Fed 
Table 21. BSR Process Operation Conditions \& Results for Original Simulant Runs Fall 2009

\begin{tabular}{|c|c|c|c|c|c|c|}
\hline Run Date & $8 / 26 / 09$ & $9 / 02 / 09$ & $9 / 08 / 09$ & $9 / 10 / 09$ & $9 / 15 / 09$ & $9 / 17 / 09$ \\
\hline Slurry Feed Rate & $1 \mathrm{~mL} / \mathrm{min}$ & $1 \mathrm{~mL} / \mathrm{min}$ & $1 \mathrm{~mL} / \mathrm{min}$ & $1 \mathrm{~mL} / \mathrm{min}$ & $1 \mathrm{~mL} / \mathrm{min}$ & $1 \mathrm{~mL} / \mathrm{min}$ \\
\hline DMR Bed Temp & $720^{\circ} \mathrm{C}$ & $720^{\circ} \mathrm{C}$ & $720^{\circ} \mathrm{C}$ & $685-715^{\circ} \mathrm{C}$ & $685-715^{\circ} \mathrm{C}$ & $685-715^{\circ} \mathrm{C}$ \\
\hline $\begin{array}{l}\text { Superheated } \\
\text { Steam }\end{array}$ & $0.60 \mathrm{~g} / \mathrm{min}$ & $0.60 \mathrm{~g} / \mathrm{min}$ & $0.60 \mathrm{~g} / \mathrm{min}$ & $0.60 \mathrm{~g} / \mathrm{min}$ & $0.60 \mathrm{~g} / \mathrm{min}$ & $0.60 \mathrm{~g} / \mathrm{min}$ \\
\hline $\begin{array}{l}\text { DMR Control } \\
\text { Pressure }\end{array}$ & -3 in $w c$ & -3 in wc & -3 in wc & -3 in wc & -3 in wc & -3 in wc \\
\hline Carbon & $\begin{array}{c}20 \mathrm{~g} / \\
100 \mathrm{~mL} \text { feed } \\
/ \text { clay } \\
\text { mixture } \\
(0.2 \mathrm{~g} \\
\mathrm{C} / \mathrm{min}) \\
\end{array}$ & $\begin{array}{c}20 \mathrm{~g} / 100 \mathrm{~mL} \\
\text { feed / clay } \\
\text { mixture } \\
(0.2 \mathrm{~g} \mathrm{C} / \mathrm{min})\end{array}$ & $\begin{array}{c}20 \mathrm{~g} / 100 \mathrm{~mL} \\
\text { feed / clay } \\
\text { mixture } \\
(0.2 \mathrm{~g} \mathrm{C} / \mathrm{min})\end{array}$ & $\begin{array}{c}20 \mathrm{~g} / 100 \mathrm{~mL} \\
\text { feed / clay } \\
\text { mixture } \\
(0.2 \mathrm{~g} \mathrm{C} / \mathrm{min})\end{array}$ & $\begin{array}{c}16 \mathrm{~g} / \\
100 \mathrm{~mL} \text { feed } \\
/ \text { clay } \\
\text { mixture } \\
(0.16 \mathrm{~g} \\
\mathrm{C} / \mathrm{min}) \\
\end{array}$ & $\begin{array}{c}16 \mathrm{~g} / \\
100 \mathrm{~mL} \text { feed } \\
/ \text { clay } \\
\text { mixture } \\
(0.16 \mathrm{~g} \\
\mathrm{C} / \mathrm{min}) \\
\end{array}$ \\
\hline $\begin{array}{l}\text { Total Controlled } \\
\text { Gas Flow }\end{array}$ & $700 \mathrm{sccm}$ & $700 \mathrm{sccm}$ & $700 \mathrm{sccm}$ & $700 \mathrm{sccm}$ & $700 \mathrm{sccm}$ & $700 \mathrm{sccm}$ \\
\hline $\begin{array}{l}\mathrm{H}_{2} \text { Concentration } \\
\text { Control }\end{array}$ & $1.5-3.0 \%$ & $1.5-3.0 \%$ & $1.5-3.0 \%$ & $1.5-3.0 \%$ & $1.5-3.0 \%$ & $1.5-3.0 \%$ \\
\hline $\begin{array}{l}\text { Post Feed Run } \\
\text { Time (hrs) }\end{array}$ & 0 & 0.5 & 1.5 & 2 & 5 & 3 \\
\hline $\begin{array}{l}\text { Product Quantity } \\
\text { (g) before } \\
\text { Sampling }\end{array}$ & 26.6 & 35.3 & 32 & 32 & 31.9 & 30.3 \\
\hline Feed Quantity (g) & $\begin{array}{c}\text { Not } \\
\text { recorded }\end{array}$ & Not recorded & Not recorded & 118 & 120 & 121 \\
\hline $\begin{array}{l}\text { Off Gas } \\
\text { Conditioning }\end{array}$ & $\begin{array}{l}\text { Bubbler / } \\
\text { Dry Ice }\end{array}$ & $\begin{array}{l}\text { Bubbler / Dry } \\
\text { Ice }\end{array}$ & $\begin{array}{l}\text { Bubbler / Dry } \\
\text { Ice and } 50 \text { um } \\
\text { filter }\end{array}$ & $\begin{array}{l}\text { Bubbler / Dry } \\
\text { Ice and } 25 \text { um } \\
\text { / } 2 \text { um filter } \\
\text { train }\end{array}$ & $\begin{array}{c}\text { Bubbler and } \\
25 \text { um } / 2 \\
\text { um filter } \\
\text { train } \\
\end{array}$ & $\begin{array}{c}\text { Bubbler and } \\
25 \text { um / } 2 \\
\text { um filter } \\
\text { train }\end{array}$ \\
\hline $\begin{array}{l}\text { DMR Temp } \\
\text { Control }\end{array}$ & Bed Temp & Bed Temp & $\begin{array}{l}\text { Bed Surface } \\
\text { Temp }\end{array}$ & $\begin{array}{l}\text { Reaction Zone } \\
\text { Top }\end{array}$ & $\begin{array}{l}\text { Reaction } \\
\text { Zone Top }\end{array}$ & $\begin{array}{l}\text { Reaction } \\
\text { Zone Top }\end{array}$ \\
\hline Combined Runs & \multicolumn{3}{|c|}{ These three runs combined to Simulant 1} & \multicolumn{3}{|c|}{ These three runs combined to Simulant 2} \\
\hline
\end{tabular}

\subsubsection{Fall 2010 Campaigns}

The Fall 2010 campaigns consisted of two runs using non-radioactive WTP-SW simulant and two runs using radioactive WTP-SW simulant that was produced by concentrating DWPF melter recycle and shimming it with radionuclides of interest. The two campaigns were performed in two different BSR units that were identical in configuration. Since the non-radioactive and radioactive BSR systems were identical, the operating parameters determined for the non-radioactive runs were used in the radioactive runs.

The target for the product LOI for this set of runs was reduced from $10-12 \mathrm{wt} \%$ to less than $5 \mathrm{wt} \%$. The coal addition rate was further lowered from the $0.16 \mathrm{~g} / \mathrm{min}$ used at the end of the Fall 2009 campaign to $0.086 \mathrm{~g} / \mathrm{min}$. This was done to achieve more accurate REDOX measurements on the product while it also reduces product volume. Residual coal interferences in the REDOX measurement are suspected due to similar effects observed when unreacted coal is mixed in with the REDOX standard Environmental Assessment (EA) glass. Beginning with the first 9/8/10 radioactive WTP SW run, the measurement for unreacted coal was changed to LOI - LOD which is the (Loss On Ignition - Loss On Drying). The postfeed run time was typically greater than 2 hours in order to reduce the LOI. All process changes were approved by TTT before they were implemented. 
The REDOX LOI, and LOI-LOD data for the Fall 2010 runs are given in Table 22. The REDOX for the two non-radioactive simulant runs measured 0.65 and 0.78 . The REDOX for the two radioactive simulant runs measured about 0.26 , i.e., more oxidized than the simulant runs. Although no control parameters were significantly different from the simulant runs vs. the latter radioactive runs, there were indications of air inleakage during the radioactive runs (see Appendix $\mathrm{C}$ ) that could possibly explain the lower REDOX values.

Table 22. BSR REDOX and LOI/LOD for Simulant and Radioactive Runs, Fall 2010

\begin{tabular}{|l|c|c|c|c|}
\hline & \multicolumn{2}{|c|}{ NON-RADIOACTIVE } & \multicolumn{2}{c|}{ RADIOACTIVE } \\
\hline Run Date & $\mathbf{8 / 1 8 / 1 0}$ & $\mathbf{8 / 2 3 / 1 0}$ & $\mathbf{9 / 8} / \mathbf{1 0}$ & $\mathbf{9 / 1 3 / 1 0}$ \\
\hline Product REDOX & 0.78 & 0.65 & 0.261 & 0.257 \\
\hline Product LOI & $4.34 \%$ & $1.72 \%$ & $2.49 \%$ & $1.68 \%$ \\
\hline Product LOI-LOD & na & na & $1.79 \%$ & $1.48 \%$ \\
\hline
\end{tabular}

Since solids carryover from the DMR to the condenser bubbler was undesirable, the gas velocity leaving the DMR was reduced by lowering the superheated steam feed from $0.6 \mathrm{~g} / \mathrm{min}$ to $0.4 \mathrm{~g} / \mathrm{min}$ and by lowering the total non-condensable gas flow from $700 \mathrm{sccm}$ to $500 \mathrm{sccm}$.

At this point, no process control existed for REDOX nor was there a specific target range.

Although not requested by TTT, a mass balance on the process operation was performed for these campaigns to support DOE requests for mass balances for the BSR runs. Though fewer solids carried over into the condenser bubbler than during the Fall 2009 campaign, a visible amount did carry-over and were easily seen in the off-gas components.

The actual BSR process operating conditions for the four Fall 2010 campaign runs are shown in Table 23. All off-gas conditioning included the bubbler and a 25 micron filter which was followed by a 2 micron filter. Temperature control is from top of the reaction zone. 
SRNL-STI-2011-00331

Revision 0

Table 23. BSR Process Operation Conditions for Simulant and Radioactive Runs, Fall 2010

\begin{tabular}{|c|c|c|c|c|}
\hline Run Date & $8 / 18 / 10$ & $8 / 23 / 10$ & $9 / 8 / 10$ & $9 / 13 / 10$ \\
\hline Run Type & SIM A & SIM A & RAD A & RAD A \\
\hline Slurry Feed Rate & $1 \mathrm{~mL} / \mathrm{min}$ & $0.8-1 \mathrm{~mL} / \mathrm{min}$ & $0.9-1.3 \mathrm{~mL} / \mathrm{min}$ & $0.9-1.3 \mathrm{~mL} / \mathrm{min}$ \\
\hline $\begin{array}{l}\text { DMR Bed Temp while } \\
\text { Feeding }\end{array}$ & $700-705 c C$ & $695-705^{\circ} \mathrm{C}$ & $720^{\circ} \mathrm{C}$ & $685-715^{\circ} \mathrm{C}$ \\
\hline Superheated Steam & $0.40 \mathrm{~g} / \mathrm{min}$ & $0.40 \mathrm{~g} / \mathrm{min}$ & $0.40 \mathrm{~g} / \mathrm{min}$ & $0.40 \mathrm{~g} / \mathrm{min}$ \\
\hline DMR Control Pressure & -3 inwe & -3 inwc & -3 inwe & -3 inwc \\
\hline Carbon & $\begin{array}{c}21.5 \mathrm{~g} / 250 \mathrm{~mL} \\
\text { feed / clay } \\
\text { mixture } \\
(0.086 \mathrm{~g} \mathrm{C} / \mathrm{min})\end{array}$ & $\begin{array}{c}21.5 \mathrm{~g} / 250 \mathrm{~mL} \\
\text { feed / clay } \\
\text { mixture } \\
(0.086 \mathrm{~g} \mathrm{C} \mathrm{/} \mathrm{min}) \\
\end{array}$ & $\begin{array}{c}21.5 \mathrm{~g} / 250 \mathrm{~mL} \\
\text { feed / clay mixture } \\
(0.086 \mathrm{~g} \mathrm{C} / \mathrm{min})\end{array}$ & $\begin{array}{l}21.5 \mathrm{~g} / 250 \mathrm{~mL} \\
\text { feed / clay mixture } \\
(0.086 \mathrm{~g} \mathrm{C} / \mathrm{min})\end{array}$ \\
\hline Total Controlled Gas Flow & $500 \mathrm{sccm}$ & $500 \mathrm{sccm}$ & $500 \mathrm{sccm}$ & $500 \mathrm{sccm}$ \\
\hline $\mathrm{H}_{2}$ Concentration Control & $1.5-3.0 \%$ & $1.5-3.0 \%$ & $1.5-3.0 \%$ & $1.5-3.0 \%$ \\
\hline Post Feed Run Time (hrs) & 2.25 & 2.5 & 0 & 2 \\
\hline $\begin{array}{l}\text { Product Quantity (g) before } \\
\text { Sampling }\end{array}$ & 82.6 & 78.2 & 26.46 & 69.21 \\
\hline Feed Quantity (g) & 322 & 320.5 & 126.9 & 306.5 \\
\hline NOTES & $\begin{array}{l}\text { Feed pluggage, } \\
\text { diluted feed early } \\
\text { in run }\end{array}$ & Used diluted feed & Air Leak & Air Leak \\
\hline
\end{tabular}

Only the process trends from the 8/23/10 run will be shown in the body of this report. Figure 26 shows the temperature trend and Figure 27 shows the off-gas trend. The process trends for all of the Fall 2010 campaign runs (two from surrogate WTP SW and two from radioactive WTP SW) are shown in Appendix C. Notice in the 8/23/10 off-gas trend (Figure 27) how the BSR operator drove the Air\% (yellow line) manually between $10 \%$ and $100 \%$ repeatedly and still maintained the $\mathrm{H}_{2}$ concentration within the nominal specified limits of 1 to $3 \%$. For the BSR operations, this is one indication that $\mathrm{H}_{2}$ control does not equal REDOX control as REDOX control requires a fairly constant Air\% during feeding. 


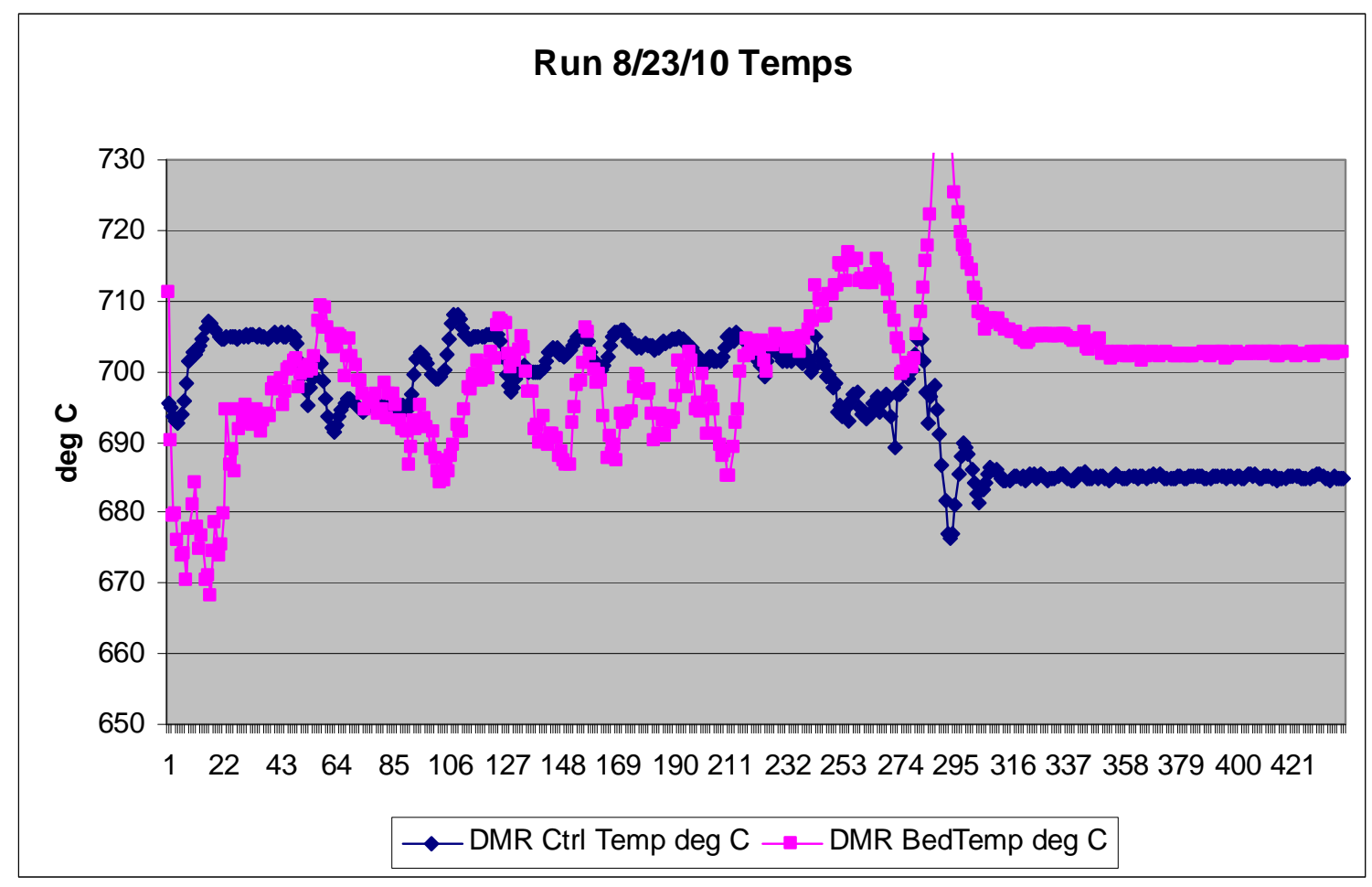

Figure 26. Run 8/23/10 Temperatures in DMR

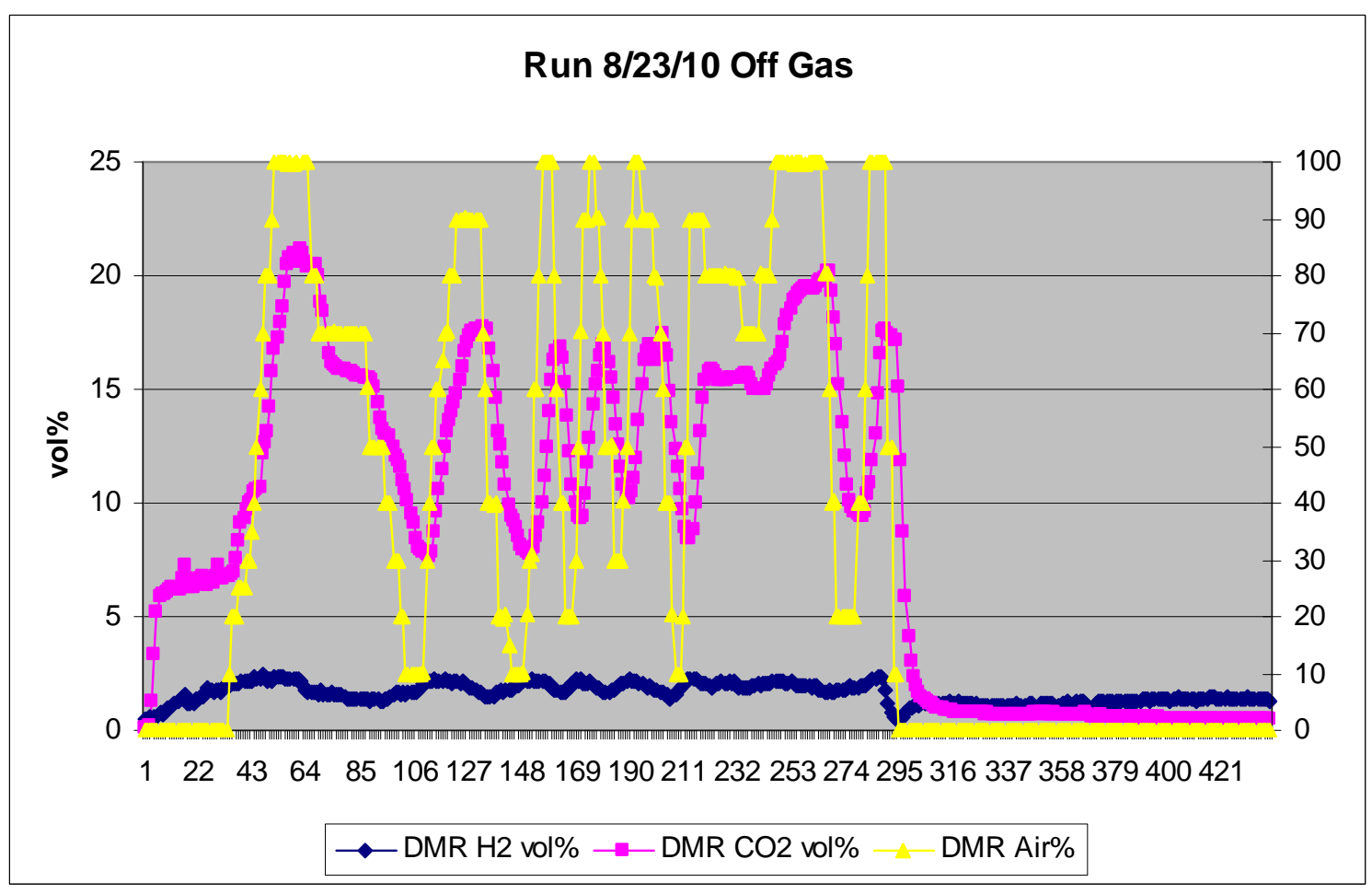

Figure 27. Run 8/23/10 Off Gas Concentrations and Air\% Fed 
The spring 2011 campaign consisted of 5 runs using non-radioactive WTP SW simulant with emphasis on using the developed product LOI control and product REDOX control. Emphasis was also placed on performing a better mass balance. After the WTP SW simulant and radioactive campaigns in the Fall of 2010 a methodology to control the product REDOX in the BSR was investigated and used on other Hanford waste streams. After those campaigns the WTP SW simulant was rerun using the gas REDOX control as given in reference 49 .

The ability to perform a better mass balance was aided starting in January 2011 by the addition of quartz wool to the crossover tube from the DMR to the condenser. The quartz wool filtered out the bulk of the carryover solids and kept the quantity very low in the bubbler. This helped improve the mass balance by reducing the amount of possible leached ions into the bubbler water from (reacted and unreacted) solids that were carried over.

The actual BSR REDOX and LOI data for the five Spring 2011 campaign runs are shown in Table 24. This was the first time that the operating parameters included controlling Air $\%$ and $\mathrm{CO}_{2} / \mathrm{mL}$ to control REDOX and LOI-LOD respectively.

Table 24. BSR Process Operation Conditions for Simulant Re-Runs, Spring 2011

\begin{tabular}{|l|c|c|c|c|c|}
\hline Run Date & $\mathbf{3 / 1} / \mathbf{1 1}$ & $\mathbf{3 / 3} / \mathbf{1 1}$ & $\mathbf{3 / 4} / \mathbf{1 1}$ & $\mathbf{3 / 7 / 1 1}$ & $\mathbf{3 / 8} / \mathbf{1 1}$ \\
\hline Product REDOX & 0.19 & 0.23 & 0.18 & 0.18 & 0.15 \\
\hline Product LOI - LOD & $0.36 \%$ & $0.69 \%$ & $0.67 \%$ & $0 \%$ & $0.08 \%$ \\
\hline
\end{tabular}

Notice all the product REDOX measurements are in the range of 0.15 to 0.23 as desired. Also notice that the product LOI-LOD was $<1 \%$ which is very desirable. It should be noted that no attempts to date have been pursued to go back and apply this redox control strategy to the radioactive WTP-SW feed.

For LOI control, the operator monitored the cumulative value of $\mathrm{CO}_{2} / \mathrm{mL}$ fed to the DMR and operated the DMR in post feed operation until a predetermined endpoint was achieved. This ensured the product did not have excessive, e.g., $>5 \mathrm{wt} \%$ LOI, unreacted coal in it. This was based on an imperfect mass balance of carbon since the MS did not measure CO.

(Carbon fed into DMR) - (Carbon Leaving as $\left.\mathrm{CO}_{2}\right)=$ Unreacted carbon in product

The $\mathrm{CO}_{2} / \mathrm{mL}$ fed endpoint was determined experimentally in the non-rad BSR after REDOX control was established. Since the $\mathrm{CO}_{2} / \mathrm{mL}$ fed vs product LOI was a linear relationship, two runs would be performed at different endpoints. A line would be drawn between the two $\mathrm{CO}_{2} / \mathrm{mL}$ fed vs product LOI points and the $\mathrm{CO}_{2} / \mathrm{mL}$ fed would be determined for the desired product LOI.

The control begins with the MINCALC ${ }^{\mathrm{TM}}$ calculation for the stoichiometric amount of carbon required to complete the denitration process. This stoichiometric amount of carbon is then converted to an amount of the actual type of coal that is being used. However, some of the carbon goes into generating heat, some doesn't react, and some is lost as off-gas carryover. Therefore, more coal is needed than is calculated. The required amount of coal must be determined experimentally and is usually expressed as a factor times the stoichiometric amount. The commonly agreed to value between SRNL and TTT dating back to the Fall 2010 WTP SW simulant BSR runs was nominally 1.3X stoichiometric amount.

Many parameters can affect the REDOX potential in the BSR and they all must be kept as constant as possible (once determined). The parameters that are kept constant are: 
SRNL-STI-2011-00331

Revision 0

- Reactor Temperature $\left(700^{\circ} \mathrm{C}-740^{\circ} \mathrm{C}\right)$

- Slurry Feed Rate $(1 \mathrm{~mL} / \mathrm{min})$

- Slurry Feed Concentration (if slurry has to be diluted for better flow property, then the air flow to get the same REDOX must be lowered by a linear amount)

- Air\% of non-condensable gases fed to DMR

- $\mathrm{O}_{2}$ concentration (controlled by air\% fed, determined experimentally from REDOX, not measurable by the MS, $\sim 10^{-21}$ to $\left.10^{-18} \mathrm{~atm}\right)$

- The Superheated Steam Rate $(0.4 \mathrm{~g} / \mathrm{min})$ and Total Gas Flow (Air $+\mathrm{N}_{2}+$ Argon $\left.=500 \mathrm{sccm}\right)$ were kept constant and it is unknown at this point how much of a change to REDOX these would affect.

The actual BSR process operating conditions for the five Spring 2011 campaign runs are shown in Table 25. For the first time, these operating parameters include Air $\%$ and $\mathrm{CO}_{2} / \mathrm{mL}$ to control REDOX and LOILOD respectively. Also, unlike in previous BSR process operation condition tables above, the 'Carbon' levels are expressed in Table 25 as the amount times the stoichiometric amount required for denitration, i.e., carbon at $1.3 \mathrm{X}$ would provide $30 \%$ 'excess' carbon than actual amount required for a 1:1 carbon to (nitrate + nitrite) molar basis.

Table 25. BSR Process Operation Conditions for WTP SW Re-Runs, Spring 2011

\begin{tabular}{|l|c|c|c|c|c|}
\hline Run Date & $\mathbf{3 / 1 / 1 1}$ & $\mathbf{3 / 3} / \mathbf{1 1}$ & $\mathbf{3} / \mathbf{4} / \mathbf{1 1}$ & $\mathbf{3 / 7 / 1 1}$ & $\mathbf{3 / 8} / \mathbf{1 1}$ \\
\hline Slurry Feed Rate & $1 \mathrm{~mL} / \mathrm{min}$ & $1 \mathrm{~mL} / \mathrm{min}$ & $1 \mathrm{~mL} / \mathrm{min}$ & $1 \mathrm{~mL} / \mathrm{min}$ & $1 \mathrm{~mL} / \mathrm{min}$ \\
\hline $\begin{array}{l}\text { DMR Bed Temp while } \\
\text { feeding }\end{array}$ & $690-730^{\circ} \mathrm{C}$ & $714-725^{\circ} \mathrm{C}$ & $713-730^{\circ} \mathrm{C}$ & $708-732^{\circ} \mathrm{C}$ & $720-745^{\circ} \mathrm{C}$ \\
\hline Superheated Steam & $0.40 \mathrm{~g} / \mathrm{min}$ & $0.40 \mathrm{~g} / \mathrm{min}$ & $0.40 \mathrm{~g} / \mathrm{min}$ & $0.40 \mathrm{~g} / \mathrm{min}$ & $0.40 \mathrm{~g} / \mathrm{min}$ \\
\hline $\begin{array}{l}\text { DMR Control } \\
\text { Pressure }\end{array}$ & $-4 \mathrm{inwc}$ & $-4 \mathrm{inwc}$ & $-4 \mathrm{inwc}$ & $-4 \mathrm{inwc}$ & $-4 \mathrm{inwc}$ \\
\hline Carbon & $1.3 \mathrm{x}$ & $1.5 \mathrm{x}$ & $1.5 \mathrm{x}$ & $1.5 \mathrm{x}$ & $1.5 \mathrm{x}$ \\
\hline $\begin{array}{l}\text { Total Controlled Gas } \\
\text { Flow }\end{array}$ & $500 \mathrm{sccm}$ & $500 \mathrm{sccm}$ & $500 \mathrm{sccm}$ & $500 \mathrm{sccm}$ & $500 \mathrm{sccm}$ \\
\hline Air\% during feed & $20 \%$ & $22 \%$ & $22-23 \%$ & $22 \%$ & $21 \%$ \\
\hline CO $\mathbf{2} / \mathbf{m L}$ & 10.9 & 13.25 & 13.08 & 13.26 & 9.7 \\
\hline $\begin{array}{l}\text { Product Quantity (g) } \\
\text { before sampling }\end{array}$ & 22.58 & 28.66 & 28.84 & 24.67 & 25.82 \\
\hline Feed Quantity (g) & 80.2 & 102.8 & 103.5 & 88.5 & 92.6 \\
\hline
\end{tabular}

Only the processing parameters from the 3/3/11 run will be shown in the body of this report, see Figure 28 and Figure 29. The process trends for all of the Spring 2011 campaign runs are shown in Appendix D. Notice on the off gas trend how the Gas REDOX is nearly constant at 10 and the Air\% is nearly constant at $20-22 \%$. 


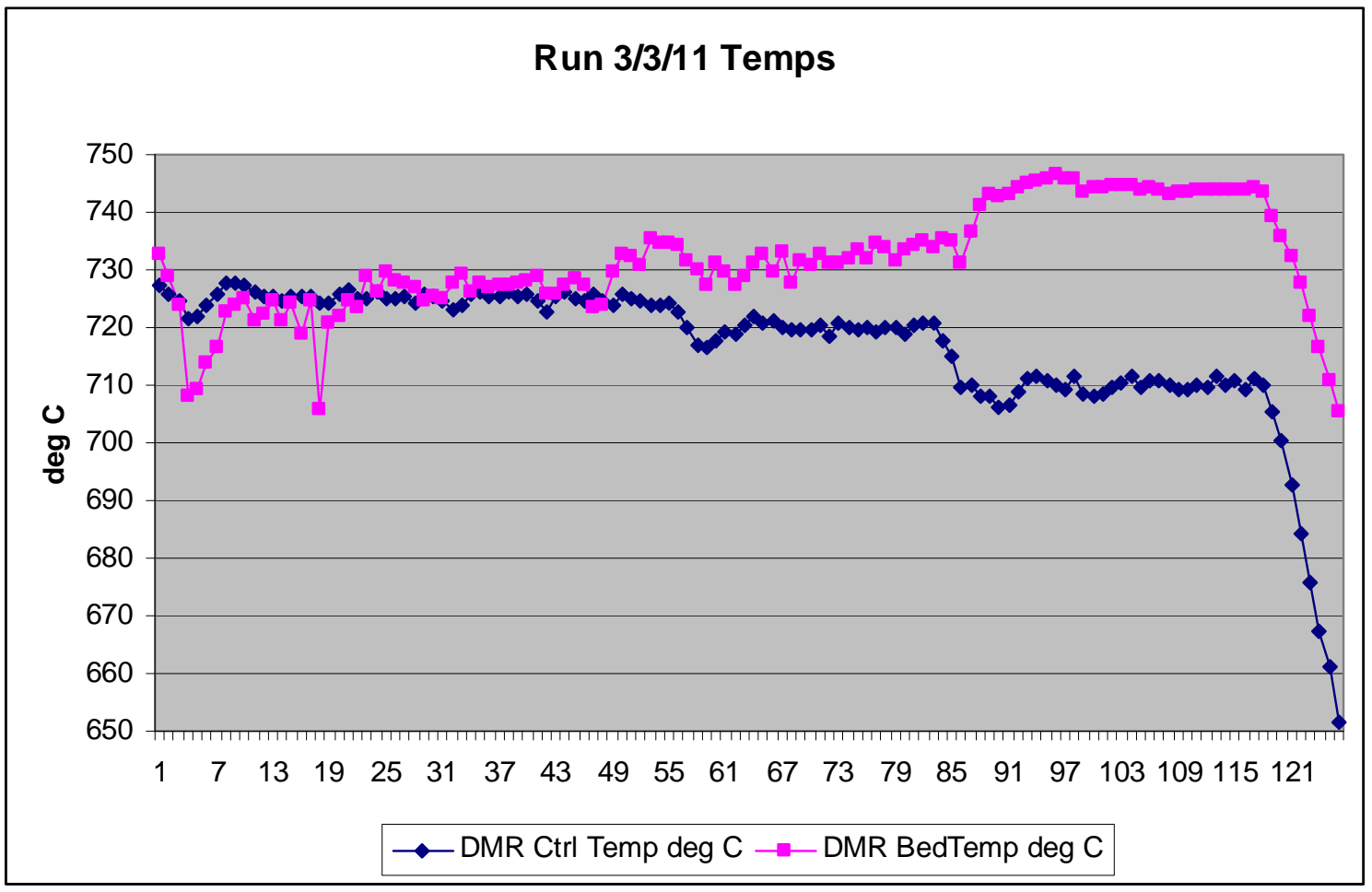

Figure 28. Run 3/3/11 Temperatures in DMR

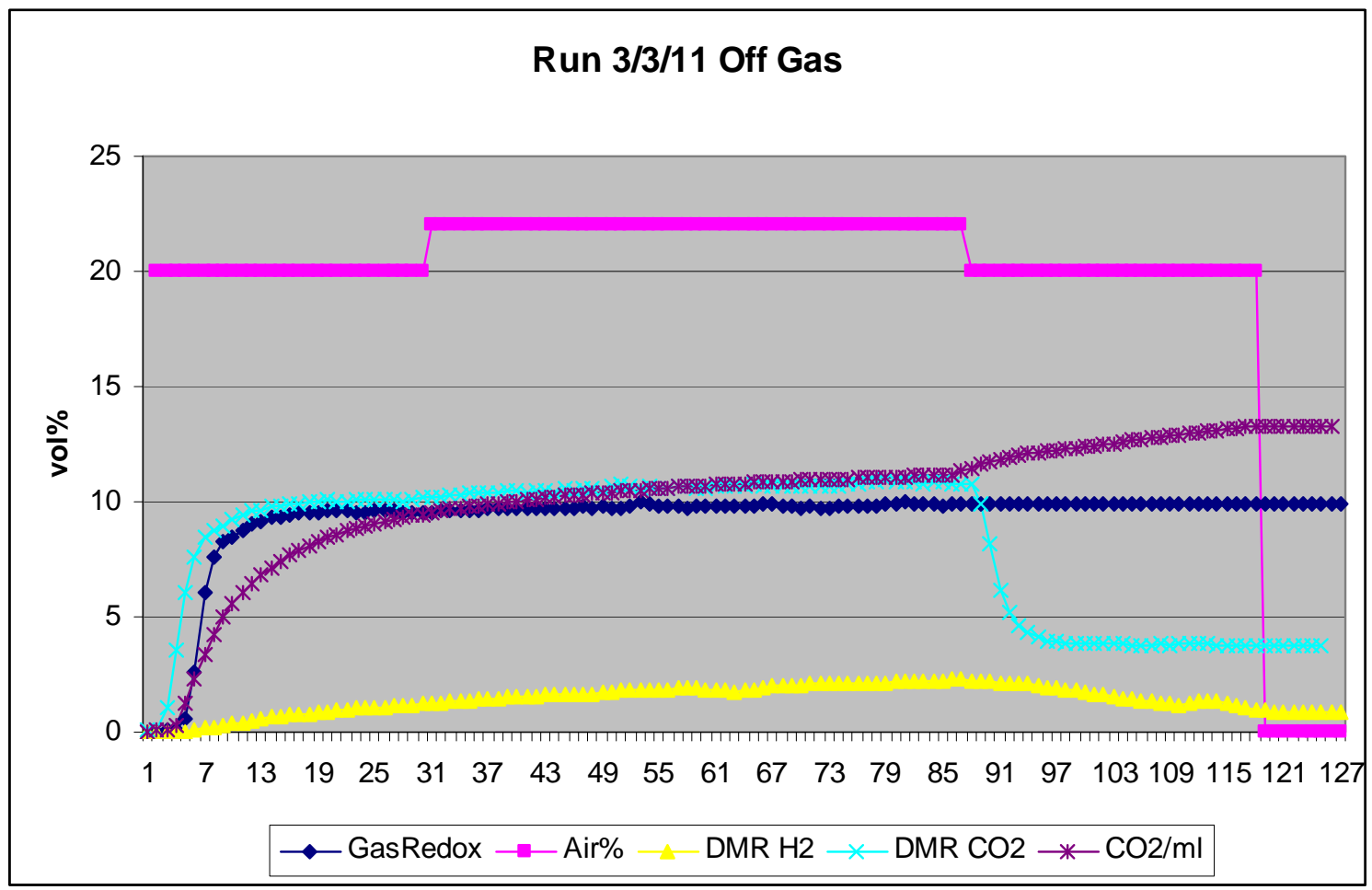

Figure 29. Run 3/3/11 Off Gas Concentrations and Air\% Fed 


\subsection{Mass Balance Calculational Results}

The input and output masses for the various campaigns are shown in Table 26 and Table 27.

Table 26. Input Stream Masses for WTP SW Campaigns

\begin{tabular}{|c|c|c|c|}
\hline INPUT STREAM & $\begin{array}{l}\text { Fall (August) } 2010 \\
\text { Simulant } \\
\text { Campaign [grams] }\end{array}$ & $\begin{array}{l}\text { Spring } 2011 \text { Simulant } \\
\text { Campaign [grams] }\end{array}$ & $\begin{array}{c}\text { Fall (September) } 2010 \\
\text { Radioactive Campaign } \\
\text { [grams] }\end{array}$ \\
\hline Feed-Supernate & 441.68 & 336.30 & 312.76 \\
\hline Feed-Fe( $\left(\mathrm{NO}_{3}\right)_{3} * 9 \mathrm{H}_{2} \mathrm{O}$ & 11.76 & 8.96 & 6.55 \\
\hline Feed-Coal $\left(\right.$ Coal $\left._{u n}\right)$ & 5.53 & 0.60 & 2.30 \\
\hline Feed-Coal Ash $\left(\right.$ Coal $\left._{a s h}\right)$ & 1.83 & 1.71 & 0.91 \\
\hline Feed-Clay-OptiKasT $^{\circledR}$ & 52.07 & 39.63 & 36.87 \\
\hline Feed-Clay-Sagger $\mathbf{X X}^{\circledR}$ & 63.76 & 48.63 & 45.15 \\
\hline
\end{tabular}

Table 27. Output Stream Masses for WTP SW Campaigns

\begin{tabular}{|c|c|c|c|}
\hline OUTPUT STREAM & $\begin{array}{c}\text { Fall (August) } 2010 \\
\text { Simulant Campaign } \\
\text { [grams] }\end{array}$ & $\begin{array}{l}\text { Spring } 2011 \text { Simulant } \\
\text { Campaign [grams] }\end{array}$ & $\begin{array}{c}\text { Fall (September) } \\
2010 \text { Radioactive } \\
\text { Campaign [grams] }\end{array}$ \\
\hline Granular Product & 171.42 & 130.60 & 120.70 \\
\hline $\begin{array}{l}\text { DMR Condensate } \\
\text { Filtrate }\end{array}$ & 749.59 & 1016.69 & 567.55 \\
\hline $\begin{array}{l}\text { DMR Condensate } \\
\text { Solids }\end{array}$ & 0.0153 & $0.0253^{*}$ & $0.0113^{\&}$ \\
\hline Crossbar Filtrate & 140.81 & $0^{* *}$ & 192.44 \\
\hline Crossbar Solids & 0.00578 & $1.293^{* * *}$ & $0.00615^{\&}$ \\
\hline \multirow{2}{*}{ Seal Pot Filtrate } & \multirow{2}{*}{ None } & 335.86 (Rinse) & \multirow{2}{*}{ None } \\
\hline & & 110.73 (Drain) & \\
\hline \multirow{2}{*}{ Seal Pot Solids } & \multirow{2}{*}{ None } & 0.0631 (Rinse) & \multirow{2}{*}{ None } \\
\hline & & 0.0217 (Drain) & \\
\hline
\end{tabular}

*DMR Condensate solids so low could not analyze so included mass in granular product total

${ }^{* *}$ No Crossbar filtrate because no rinse since used Quartz Wool

${ }^{* * *}$ Crossbar solids are Quartz Wool Solids

${ }^{\&}$ The RAD A condensate and crossbar solids masses are estimated based on the filters with solids being dissolved in $100 \mathrm{~mL}$ or $\mathrm{g}$ of solution and then analyzed. The concentration values were then based on the estimated masses.

The concentrations of key species in the input and output streams for are shown in Table 28 through Table 31. Some cells are marked as 'BDL' for below detection limits. 
Table 28. Key Species Concentrations for Fall 2010 Simulant Input and Output Streams

\begin{tabular}{|c|c|c|c|c|c|c|c|c|c|c|c|c|}
\hline Method & $\begin{array}{c}\text { Non- } \\
\text { Radioactive } \\
\text { Species }\end{array}$ & $\begin{array}{c}\text { Feed- } \\
\text { Supernate } \\
\text { [ug/L] }\end{array}$ & $\begin{array}{c}\text { Feed- } \\
\mathrm{Fe}\left(\mathrm{NO}_{3}\right) 3 * \\
9 \mathrm{H}_{2} \mathrm{O}[\mathrm{wt} \%]\end{array}$ & $\begin{array}{l}\text { Feed- } \\
\text { Coal } \\
{[w t \%]}\end{array}$ & $\begin{array}{c}\text { Feed- } \\
\text { Coal } \\
\text { Ash } \\
\text { [wt\%] }\end{array}$ & $\begin{array}{c}\text { Feed-Clay- } \\
\text { OptiKasT }^{\circledR} \\
\text { [wt\%] }^{\text {[wt }}\end{array}$ & $\begin{array}{c}\text { Feed- } \\
\text { Clay- } \\
\text { Sagger } \\
\text { XX }^{\circledR} \\
{[w t \%]} \\
\end{array}$ & $\begin{array}{c}\text { Granular } \\
\text { Product } \\
\text { [wt\%] }\end{array}$ & $\begin{array}{c}\text { DMR } \\
\text { Condensate } \\
\text { Filtrate }[\mathrm{ug} / \mathrm{L}]\end{array}$ & $\begin{array}{c}\text { DMR } \\
\text { Condensate } \\
\text { Solids [wt } \% \text { ] }\end{array}$ & $\begin{array}{c}\text { Crossbar } \\
\text { Filtrate } \\
\text { [ug/L] }\end{array}$ & $\begin{array}{c}\text { Crossbar } \\
\text { Solids } \\
\text { [wt\%] }\end{array}$ \\
\hline \multirow{3}{*}{ ICP-MS } & ${ }^{133} \mathrm{Cs}$ & $1.96 \mathrm{E}+06$ & 0.00 & 0.00 & 0.00 & 0.00 & 0.00 & 0.42 & $1.99 \mathrm{E}+04$ & 3.16 & $5.34 \mathrm{E}+03$ & 0.52 \\
\hline & $\mathrm{Re}$ & $3.83 \mathrm{E}+05$ & 0.00 & 0.00 & 0.00 & 0.00 & 0.00 & 0.067 & $1.07 \mathrm{E}+04$ & 0.40 & $1.58 \mathrm{E}+03$ & 0.12 \\
\hline & ${ }^{127} \mathrm{I}$ & $1.05 \mathrm{E}+05$ & 0.00 & 0.00 & 0.00 & 0.00 & 0.00 & 0.014 & $1.44 \mathrm{E}+04$ & 0.24 & $8.27 \mathrm{E}+03$ & 0.15 \\
\hline \multirow{4}{*}{ ICP-ES } & $\mathrm{Al}$ & $1.48 \mathrm{E}+07$ & 0.00 & 0.71 & 13.81 & 19.98 & 16.66 & 15.90 & $1.77 \mathrm{E}+04$ & 72.14 & $7.00 \mathrm{E}+04$ & 30.36 \\
\hline & $\mathrm{Cr}$ & $3.15 \mathrm{E}+05$ & 0.00 & 0.00 & 0.00 & 0.00 & 0.00 & 0.10 & $<1.00 \mathrm{E}+02$ & 0.23 & $4.60 \mathrm{E}+02$ & 0.55 \\
\hline & $\mathrm{Na}$ & $5.38 \mathrm{E}+07$ & 0.00 & 0.02 & 0.36 & 0.01 & 0.07 & 12.63 & $5.66 \mathrm{E}+04$ & 6.91 & $6.03 \mathrm{E}+04$ & 21.36 \\
\hline & $\mathrm{Si}$ & $5.91 \mathrm{E}+05$ & 0.00 & 1.45 & 28.40 & 20.88 & 25.75 & 18.63 & $9.92 \mathrm{E}+03$ & 1.16 & $3.77 \mathrm{E}+05$ & 31.05 \\
\hline \multirow{2}{*}{ IC } & $\mathrm{Cl}$ & $3.77 \mathrm{E}+06$ & 0.00 & 0.00 & 0.00 & 0.00 & 0.00 & 0.5188 & $2.22 \mathrm{E}+05$ & NA & $3.70 \mathrm{E}+05$ & NA \\
\hline & $\mathrm{SO}_{4}{ }^{2-}$ & $5.27 \mathrm{E}+05$ & 0.00 & 1.40 & 1.02 & 0.00 & 0.00 & 0.2323 & $<1.00 \mathrm{E}+05$ & 7.11 & $1.14 \mathrm{E}+05$ & 3.82 \\
\hline
\end{tabular}

$\mathrm{NA}=$ Not available

Table 29. Key Species Concentrations for Spring 2011 Simulant Input and Output Streams

\begin{tabular}{|c|c|c|c|c|c|c|c|c|c|c|c|c|c|c|c|c|}
\hline \multirow[b]{2}{*}{ METHOD } & \multirow{2}{*}{$\begin{array}{l}\text { NON- } \\
\text { RAD. } \\
\text { SPECIES }\end{array}$} & \multirow{2}{*}{$\begin{array}{c}\text { FEED- } \\
\text { SUPERNATE } \\
{[\mathrm{ug} / \mathrm{L}]}\end{array}$} & \multirow{2}{*}{$\begin{array}{c}\text { FEED- } \\
\left.\text { FE }\left(\mathrm{NO}_{3}\right)\right)^{*} \\
9 \mathrm{H}_{2} \mathrm{O} \\
{[\mathrm{wt} \%]}\end{array}$} & \multirow{2}{*}{$\begin{array}{l}\text { FEED- } \\
\text { COAL } \\
{[\mathrm{wt} \%]}\end{array}$} & \multirow{2}{*}{$\begin{array}{l}\text { FEED- } \\
\text { COAL } \\
\text { ASH } \\
{[\mathbf{w t} \%]}\end{array}$} & \multirow{2}{*}{$\begin{array}{l}\text { FEED- } \\
\text { CLAY- } \\
\text { OptiKasT }^{\circledR} \\
\text { [wt \%] }\end{array}$} & \multirow{2}{*}{ 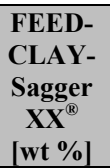 } & \multirow{2}{*}{$\begin{array}{c}\text { GRANULAR } \\
\text { PRODUCT } \\
\text { [wt \%] }\end{array}$} & \multirow{2}{*}{$\begin{array}{c}\text { DMR } \\
\text { COND. } \\
\text { FILTRATE } \\
\text { [ug/L] }\end{array}$} & \multirow{2}{*}{$\begin{array}{c}\text { DMR } \\
\text { COND. } \\
\text { SOLIDS } \\
\text { [wt \%] }\end{array}$} & \multirow{2}{*}{$\begin{array}{c}\text { CROSSBAR } \\
\text { FILTRATE } \\
\text { [ug/L] }\end{array}$} & \multirow{2}{*}{$\begin{array}{l}\text { CROSSBAR } \\
\text { SOLIDS } \\
\text { [wt \%] }\end{array}$} & \multicolumn{2}{|c|}{$\begin{array}{l}\text { SEAL POT } \\
\text { FILTRATE }\end{array}$} & \multicolumn{2}{|c|}{$\begin{array}{c}\text { SEAL POT } \\
\text { SOLIDS } \\
\end{array}$} \\
\hline & & & & & & & & & & & & & $\begin{array}{l}\text { Rinse } \\
\text { [ug/L] }\end{array}$ & $\begin{array}{l}\text { Drain } \\
\text { [ug/L] }\end{array}$ & $\begin{array}{l}\text { Rinse } \\
{[w t \%]}\end{array}$ & $\begin{array}{l}\text { Drain } \\
\text { [wt\%] }\end{array}$ \\
\hline \multirow{3}{*}{ ICP-MS } & ${ }^{133} \mathrm{Cs}$ & $2.04 \mathrm{E}+05$ & 0.00 & 0.00 & 0.00 & 0.00 & 0.00 & 0.03 & $1.69 \mathrm{E}+02$ & $\mathrm{NA}$ & $5.34 \mathrm{E}+03$ & 0.05 & $1.74 \mathrm{E}+01$ & $9.95 \mathrm{E}+02$ & 0.030 & 0.013 \\
\hline & $\mathrm{Re}$ & $2.21 \mathrm{E}+05$ & 0.00 & 0.00 & 0.00 & 0.00 & 0.00 & 0.05 & $3.40 \mathrm{E}+02$ & NA & $1.58 \mathrm{E}+03$ & 0.05 & $1.74 \mathrm{E}+01$ & $1.78 \mathrm{E}+03$ & 0.024 & 0.008 \\
\hline & ${ }^{127} \mathrm{I}$ & $6.43 \mathrm{E}+04$ & 0.00 & 0.00 & 0.00 & 0.00 & 0.00 & 0.014 & $5.21 \mathrm{E}+02$ & NA & $8.27 \mathrm{E}+03$ & 0.06 & $5.57 \mathrm{E}+01$ & $4.89 \mathrm{E}+03$ & 0.020 & 0.011 \\
\hline \multirow{4}{*}{ ICP-ES } & $\mathrm{Al}$ & $1.53 \mathrm{E}+07$ & 0.00 & 0.71 & 13.81 & 19.98 & 16.66 & 16.80 & $3.62 \mathrm{E}+02$ & NA & $7.00 \mathrm{E}+04$ & 5.27 & $1.36 \mathrm{E}+02$ & $2.40 \mathrm{E}+03$ & 8.78 & 21.20 \\
\hline & $\mathrm{Cr}$ & $3.20 \mathrm{E}+05$ & 0.00 & 0.00 & 0.00 & 0.00 & 0.00 & 0.09 & $<2.80 \mathrm{E}+01$ & NA & $4.60 \mathrm{E}+02$ & 0.03 & $\begin{array}{c}< \\
2.8 \mathrm{E}+01 \\
\end{array}$ & $2.80 \mathrm{E}+01$ & 0.09 & 0.06 \\
\hline & $\mathrm{Na}$ & $5.82 \mathrm{E}+07$ & 0.00 & 0.02 & 0.36 & 0.01 & 0.07 & 14.23 & $2.94 \mathrm{E}+03$ & $\mathrm{NA}$ & $6.03 \mathrm{E}+04$ & 4.98 & $3.35 \mathrm{E}+03$ & $4.48 \mathrm{E}+04$ & 2.85 & 1.87 \\
\hline & $\mathrm{Si}$ & $2.10 \mathrm{E}+05$ & 0.00 & 1.45 & 28.40 & 20.88 & 25.75 & 19.13 & $8.20 \mathrm{E}+03$ & NA & $3.77 \mathrm{E}+05$ & 5.41 & $1.47 \mathrm{E}+03$ & $6.01 \mathrm{E}+04$ & 0.32 & 0.91 \\
\hline \multirow{2}{*}{ IC } & $\mathrm{Cl}$ & $3.67 \mathrm{E}+06$ & 0.00 & 0.00 & 0.00 & 0.00 & 0.00 & 0.74 & $1.30 \mathrm{E}+04$ & NA & $3.70 \mathrm{E}+05$ & 4.38 & $\begin{array}{c}< \\
1.0 \mathrm{E}+04 \\
\end{array}$ & $1.15 \mathrm{E}+05$ & NA & NA \\
\hline & $\mathrm{SO}_{4}{ }^{2-}$ & $6.00 \mathrm{E}+05$ & 0.00 & 1.40 & 1.02 & 0.00 & 0.00 & 0.20 & $<1.33 \mathrm{E}+04$ & NA & $1.14 \mathrm{E}+05$ & $<0.88$ & $\begin{array}{c}< \\
1.0 \mathrm{E}+04\end{array}$ & $4.00 \mathrm{E}+04$ & NA & NA \\
\hline
\end{tabular}

$\mathrm{NA}=$ Not available 
Table 30. Key Species Concentrations for Radioactive Campaign Input and Output Streams

\begin{tabular}{|c|c|c|c|c|c|c|c|c|c|c|c|c|}
\hline Method & $\begin{array}{c}\text { Non- } \\
\text { Radioactive } \\
\text { Species }\end{array}$ & $\begin{array}{c}\text { Feed- } \\
\text { Supernate } \\
\text { [ug/L] }\end{array}$ & $\begin{array}{c}\text { Feed- } \\
\mathrm{Fe}\left(\mathrm{NO}_{3}\right)_{3} \\
* 9 \mathrm{H}_{2} \mathrm{O} \\
{[\mathrm{wt} \%]} \\
\end{array}$ & $\begin{array}{c}\text { Feed- } \\
\text { Coal } \\
{[w t \%]}\end{array}$ & $\begin{array}{c}\text { Feed- } \\
\text { Coal Ash } \\
{[w t \%]}\end{array}$ & $\begin{array}{c}\text { Feed-Clay- } \\
\text { OptiKasT }^{\circledR} \\
\text { [wt } \%]^{\text {[wo] }}\end{array}$ & $\begin{array}{c}\text { Feed-Clay- } \\
\text { Sagger XX } \\
{[w t \%]}\end{array}$ & $\begin{array}{c}\text { Granular } \\
\text { Product } \\
\text { [wt\%] }\end{array}$ & $\begin{array}{c}\text { DMR } \\
\text { Condensate } \\
\text { Filtrate } \\
{[\mathrm{ug} / \mathrm{L}]^{*}} \\
\end{array}$ & \begin{tabular}{|c|} 
DMR \\
Condensate \\
Solids \\
[wt \%]* \\
\end{tabular} & $\begin{array}{c}\text { Crossbar } \\
\text { Filtrate } \\
{[\mathrm{ug} / \mathrm{L}]^{*}}\end{array}$ & $\begin{array}{c}\text { Crossbar } \\
\text { Solids } \\
{[\mathbf{w t} \%]^{*}}\end{array}$ \\
\hline \multirow{3}{*}{ ICP-MS } & ${ }^{133} \mathrm{Cs}$ & $0.00 \mathrm{E}+00$ & 0 & 0 & 0 & 0 & 0 & 0.00035 & $3.25 \mathrm{E}+00$ & NA & $7.32 \mathrm{E}-01$ & NA \\
\hline & $\mathrm{Re}$ & $2.13 \mathrm{E}+05$ & 0 & 0 & 0 & 0 & 0 & 0.048 & $5.18 \mathrm{E}+02$ & 0.029 & $1.25 \mathrm{E}+02$ & 0.024 \\
\hline & ${ }^{127} \mathrm{I}$ & $5.35 \mathrm{E}+03$ & 0 & 0 & 0 & 0 & 0 & 0.0017 & $2.14 \mathrm{E}+02$ & 0.003 & $3.91 \mathrm{E}+01$ & $<0.01$ \\
\hline \multirow{4}{*}{ ICP-ES } & $\mathrm{Al}$ & $1.24 \mathrm{E}+07$ & 0 & 0.71 & 13.81 & 19.99 & 16.66 & 15.2 & $3.19 \mathrm{E}+02$ & 54.76 & $8.45 \mathrm{E}+03$ & 42.06 \\
\hline & $\mathrm{Cr}$ & $3.15 \mathrm{E}+05$ & 0 & 0 & 0 & 0 & 0 & 0.1 & $2.69 \mathrm{E}+01$ & 0.37 & $3.16 \mathrm{E}+01$ & 0.33 \\
\hline & $\mathrm{Na}$ & $5.38 \mathrm{E}+07$ & 0 & 0.02 & 0.36 & 0.01 & 0.07 & 17.97 & $7.97 \mathrm{E}+04$ & 17.74 & $4.20 \mathrm{E}+04$ & 25.55 \\
\hline & $\mathrm{Si}$ & $5.91 \mathrm{E}+05$ & 0 & 1.45 & 28.4 & 20.88 & 25.75 & 18 & $2.91 \mathrm{E}+04$ & 14.49 & $3.25 \mathrm{E}+04$ & 11.52 \\
\hline \multirow{2}{*}{ IC } & $\mathrm{Cl}$ & $3.77 \mathrm{E}+06$ & 0 & 0 & 0 & 0 & 0 & 1.07 & NA & NA & NA & NA \\
\hline & $\mathrm{SO}_{4}^{2-}$ & $5.27 \mathrm{E}+05$ & 0 & 1.4 & 1.02 & 0 & 0 & 0.32 & NA & $\mathrm{BDL}$ & NA & $\mathrm{BDL}$ \\
\hline
\end{tabular}

$\mathrm{NA}=$ Not available, ${ }^{*}$ Condensate and crossbar concentrations are based on individual sample analyses and quantities that are combined based on the total masses for each stream.

\section{Table 31. Key Radioactive Species Concentrations for Radioactive Run Input and Output Streams}

\begin{tabular}{|c|c|c|c|c|c|c|c|}
\hline Method & $\begin{array}{l}\text { Radioactive } \\
\text { Species }\end{array}$ & $\begin{array}{l}\text { Feed-Supernate } \\
{[\mathrm{dpm} / \mathrm{mL}]}\end{array}$ & $\begin{array}{c}\text { Granular } \\
\text { Product }[\mathrm{dpm} / \mathrm{g}]\end{array}$ & $\begin{array}{l}\text { DMR Condensate } \\
\text { Filtrate }[\mathrm{dpm} / \mathrm{mL}]^{*}\end{array}$ & $\begin{array}{l}\text { DMR Condensate } \\
\text { Solids [dpm/g]* }\end{array}$ & $\begin{array}{l}\text { Crossbar Filtrate } \\
\text { [dpm/mL]* }\end{array}$ & $\begin{array}{c}\text { Crossbar Solids } \\
\text { [dpm/g]* }\end{array}$ \\
\hline \multirow{4}{*}{ Radiochem } & ${ }^{137} \mathrm{Cs}$ & $1.98 \mathrm{E}+07$ & $4.11 \mathrm{E}+07$ & $5.82 \mathrm{E}+04$ & $5.93 \mathrm{E}+07$ & $1.57 \mathrm{E}+04$ & $7.11 \mathrm{E}+07$ \\
\hline & ${ }^{99} \mathrm{Tc}$ & $3.10 \mathrm{E}+05$ & $7.46 \mathrm{E}+05$ & $2.82 \mathrm{E}+02$ & $7.10 \mathrm{E}+05$ & $8.85 \mathrm{E}+01$ & $8.26 \mathrm{E}+04$ \\
\hline & ${ }^{129} \mathrm{I}$ & $2.66 \mathrm{E}+03$ & $5.63 \mathrm{E}+03$ & $2.24 \mathrm{E}+01$ & $8.13 \mathrm{E}+03$ & $3.24 \mathrm{E}+00$ & $6.10 \mathrm{E}+03$ \\
\hline & ${ }^{125} \mathrm{I} * *$ & $2.57 \mathrm{E}+04$ & $5.21 \mathrm{E}+04$ & $1.94 \mathrm{E}+02$ & $1.13 \mathrm{E}+05$ & $3.30 \mathrm{E}+01$ & $1.10 \mathrm{E}+06$ \\
\hline
\end{tabular}

*Condensate and crossbar concentrations are based on individual sample analyses and quantities that are combined based on the total masses for each stream; $* *{ }^{125}$ I values for all post-feed supernate analyses were decay-corrected back to the same analysis time as the original feed supernate analyses. 
The total recoveries of the key species for the key streams were calculated for the WTP SW campaigns using the logic presented in Section 3.5. The recoveries for WTP SW simulant from the Fall 2010 BSR processing campaign are shown in Table 32. The recoveries for WTP SW simulant from Spring 2011 BSR processing are shown in Table 33. The recoveries for the WTP SW radioactive campaign are shown in Table 34. No mass balance was performed on the original Fall 2009 WTP SW BSR processing campaign.

The non-radioactive ${ }^{133}$ Cesium recovery was $99 \%$ for the original Fall 2010 simulant campaign and $77 \%$ for the Spring 2011 simulant campaign. The lower recovery in the Spring 2011 simulant campaign compared to the Fall 2010 was due to the low concentration of ${ }^{133} \mathrm{Cs}$ in the feed for the Spring 2011 run (about 200,000 ug/L) versus that in the Fall 2010 campaign (about 2,000,000 ug/L). The total Cs fed for the Fall 2010 campaign was about 0.74 grams versus 0.06 grams fed in the Spring 2011 campaign. For any mass balance, it is more difficult to track a lower amount through a system and any errors are amplified which impacts the overall recovery. It is expected that had the Spring 2011 campaign ${ }^{133} \mathrm{Cs}$ feed levels been similar to the original module levels that the recovery would have been similar.

The Re recovery was $86 \%$ for the Fall 2010 campaign and 95\% for the Spring 2011 campaign. The ${ }^{127}$ I recovery was $91 \%$ for the Fall 2010 campaign and 106\% for the Spring 2011 campaign. The $\mathrm{SO}_{4}$ recovery was indeterminate for all WTP SW runs due to the relatively low amount of sulfate in the feed vs. the coal-derived sulfur species. The $\mathrm{SO}_{4}$ recovery is very dependent on the $\mathrm{SO}_{4}$ coming in via the coal in the feed mix and how much of the coal in the feed is ashed. The approach to handle the feed coal $\mathrm{SO}_{4}$ and other species is discussed in Section 3.5 but could be further refined with dedicated studies.

Table 32. Recoveries for Key Streams and Species for WTP SW Simulant (Fall 2010)

\begin{tabular}{|c|c|c|c|c|c|c|c|}
\hline \multirow[b]{2}{*}{ Method } & \multirow[b]{2}{*}{ Element } & \multirow{2}{*}{\begin{tabular}{|c|c}
$\begin{array}{c}\text { Total } \\
\text { Recovery } \\
(\%)\end{array}$ \\
\end{tabular}} & \multicolumn{5}{|c|}{ Normalized Recoveries } \\
\hline & & & $\begin{array}{c}\text { Product } \\
\%\end{array}$ & $\begin{array}{l}\text { Condensate } \\
\text { Filtrate \% }\end{array}$ & \begin{tabular}{|c} 
Condensate \\
Solids \% \\
\end{tabular} & $\begin{array}{c}\text { Crossbar } \\
\text { Filtrates \% }\end{array}$ & \begin{tabular}{|l|} 
Crossbar \\
Solids \% \\
\end{tabular} \\
\hline \multirow{3}{*}{ ICP-MS } & ${ }^{133} \mathrm{Cs}$ & 99 & 97.8 & 2.0 & $\begin{array}{l}0.1 \\
\end{array}$ & 0.1 & 0.004 \\
\hline & $\mathrm{Re}$ & 86 & 93.3 & 6.5 & 0.1 & 0.2 & 0.01 \\
\hline & ${ }^{127} \mathrm{I}$ & 91 & 66.6 & 30.0 & 0.1 & 3.2 & 0.02 \\
\hline \multirow{4}{*}{ ICP-ES } & $\mathrm{Al}$ & 101 & 99.9 & 0.1 & 0.04 & 0.04 & 0.01 \\
\hline & $\mathrm{Cr}$ & 137 & 99.9 & $\mathrm{BDL}$ & $\mathrm{BDL}$ & 0.04 & 0.02 \\
\hline & $\mathrm{Na}$ & 107 & $\begin{array}{l}99.8 \\
\end{array}$ & 0.20 & 0.0 & 0.04 & 0.01 \\
\hline & $\mathrm{Si}$ & 114 & $\begin{array}{l}99.8 \\
\end{array}$ & 0.02 & 0.0 & 0.2 & 0.01 \\
\hline \multirow{2}{*}{ IC } & $\mathrm{Cl}$ & 78 & 80.2 & 15.1 & 0.0 & 4.7 & 0.0 \\
\hline & $\mathrm{SO}_{4}^{2-}$ & \multicolumn{6}{|c|}{ Indeterminate due to low concentration in feed and large contribution from coal } \\
\hline
\end{tabular}


Table 33. Recoveries for Key Streams and Species for WTP SW Simulant Spring 2011 Campaign

\begin{tabular}{|c|c|c|c|c|c|c|c|c|c|}
\hline \multirow[b]{2}{*}{ Method } & \multirow[b]{2}{*}{ Element } & \multirow{2}{*}{$\begin{array}{c}\text { Total } \\
\text { Recovery } \\
(\%)\end{array}$} & \multicolumn{7}{|c|}{ Normalized Recoveries } \\
\hline & & & Product \% & $\begin{array}{l}\text { Condensate } \\
\text { Filtrate \% }\end{array}$ & $\begin{array}{c}\text { Condensate } \\
\text { Solids \% }\end{array}$ & $\begin{array}{c}\text { Crossbar } \\
\text { Filtrates \% }\end{array}$ & $\begin{array}{l}\text { Crossbar } \\
\text { Solids \% }\end{array}$ & $\begin{array}{c}\text { Seal Pot } \\
\text { Filtrate\% }\end{array}$ & \begin{tabular}{|l} 
Seal Pot \\
Solids \%
\end{tabular} \\
\hline \multirow{3}{*}{ ICP-MS } & ${ }^{133} \mathrm{Cs}$ & 77 & 98.0 & 0.4 & 0.0 & 0.0 & 1.3 & 0.3 & 0.05 \\
\hline & $\mathrm{Re}$ & 95 & 98.0 & 0.6 & 0.0 & 0.0 & 1.1 & 0.3 & 0.03 \\
\hline & ${ }^{127} \mathrm{I}$ & 106 & 90.3 & 2.7 & 0.0 & 0.0 & 4.1 & 2.9 & 0.08 \\
\hline \multirow{4}{*}{ ICP-ES } & $\mathrm{Al}$ & 107 & 99.6 & 0.0 & 0.0 & 0.0 & 0.3 & 0.0 & 0.05 \\
\hline & $\mathrm{Cr}$ & 125 & 99.6 & $\mathrm{BDL}$ & $\mathrm{BDL}$ & 0.0 & 0.3 & 0.0 & 0.06 \\
\hline & $\mathrm{Na}$ & 111 & 99.6 & 0.02 & 0.0 & 0.0 & 0.3 & 0.03 & 0.01 \\
\hline & $\mathrm{Si}$ & 117 & 99.7 & 0.03 & 0.0 & 0.0 & 0.3 & 0.03 & 0.00 \\
\hline \multirow{2}{*}{ IC } & $\mathrm{Cl}$ & 99.5 & 92.1 & 1.3 & 0.0 & 0.0 & 5.4 & 1.2 & 0.00 \\
\hline & $\mathrm{SO}_{4}^{2-}$ & \multicolumn{8}{|c|}{ Indeterminate due to low concentration in feed and large contribution from coal } \\
\hline
\end{tabular}

The Re recovery was $102 \%$ for the WTP SW radioactive campaign. The ${ }^{127}$ I recovery was $151 \%$. More details of the mass balance are shown in Appendix E, Appendix F, and Appendix G. All total recoveries for the radionuclides in the WTP SW radioactive campaign were in the range of $93 \%$ to $109 \%$. The ${ }^{137} \mathrm{Cs}$ and ${ }^{99} \mathrm{Tc}$ recoveries were $94 \%$ and $109 \%$, respectively. Comparison of the total recoveries shown in Table 34 to the percent of each species in the product (Product \% column) suggests that all analytes remained predominately with the granular product in processing the feed slurries in the BSR.

Table 34. Recoveries for Key Streams and Species for the WTP SW Radioactive Campaign

\begin{tabular}{|c|c|c|c|c|c|c|c|}
\hline \multirow[b]{2}{*}{ Method } & \multirow[b]{2}{*}{ Element } & \multirow{2}{*}{$\begin{array}{c}\text { Total } \\
\text { Recovery } \\
(\%)\end{array}$} & \multicolumn{5}{|c|}{ Normalized Recoveries } \\
\hline & & & Product \% & $\begin{array}{l}\text { Condensate } \\
\text { Filtrate } \% \\
\end{array}$ & $\begin{array}{l}\text { Condensate } \\
\text { Solids \% } \\
\end{array}$ & $\begin{array}{c}\text { Crossbar } \\
\text { Filtrates } \%\end{array}$ & $\begin{array}{l}\text { Crossbar } \\
\text { Solids \% } \\
\end{array}$ \\
\hline \multirow{4}{*}{ Radiochem } & ${ }^{137} \mathrm{Cs}$ & 94 & 99.3 & 0.7 & 0.01 & 0.1 & 0.01 \\
\hline & ${ }^{125} \mathrm{I} *$ & 93 & 98.2 & 1.7 & 0.02 & 0.1 & 0.01 \\
\hline & ${ }^{129} \mathrm{I}$ & 98 & 98.0 & 1.8 & 0.02 & 0.1 & 0.02 \\
\hline & ${ }^{99} \mathrm{Tc}$ & 109 & 99.8 & 0.2 & 0.01 & 0.02 & 0.01 \\
\hline \multirow{3}{*}{ ICP-MS } & ${ }^{99} \mathrm{Tc}$ & \multicolumn{6}{|c|}{ Not performed } \\
\hline & $\mathrm{Re}$ & 102 & 99.45 & 0.5 & 0.01 & 0.04 & 0.003 \\
\hline & ${ }^{127} \mathrm{I}$ & 151 & 94.0 & 5.6 & BDL & 0.4 & $\mathrm{BDL}$ \\
\hline \multirow{4}{*}{ ICP-ES } & $\mathrm{Al}$ & 100 & 99.9 & 0.0 & 0.03 & 0.01 & 0.01 \\
\hline & $\mathrm{Cr}$ & 181 & 99.9 & 0.01 & 0.03 & 0.0 & 0.01 \\
\hline & $\mathrm{Na}$ & 151 & 99.7 & 0.2 & 0.01 & 0.04 & 0.01 \\
\hline & $\mathrm{Si}$ & 110 & 99.9 & 0.08 & 0.01 & 0.03 & 0.003 \\
\hline \multirow{2}{*}{$\mathrm{IC}$} & $\mathrm{Cl}$ & 129 & 100.0 & 0.0 & 0.0 & 0.0 & 0.0 \\
\hline & $\mathrm{SO}_{4}{ }^{2-}$ & \multicolumn{6}{|c|}{ Indeterminate due to low concentration in feed and large contribution from coal } \\
\hline
\end{tabular}

\subsection{Granular Product}

\subsubsection{Mineralogy}

The targeted mineral assemblages in the WTP SW campaigns are given in Appendix E, Appendix F, and Appendix G. (see Section 3.2.3) and the phases observed in the product are given in Table 35. Table 35 summarizes the mineralogy as determined by XRD for all the WTP SW BSR campaigns and the monoliths made from the non-radioactive and radioactive granular products. These data are shown as the 
last six data rows in Table 35 along with other XRD data from the HRI ESTD testing in 2008 and other historical campaigns. A blank cell in Table 35 indicates that the specific phase was not observed.

The mineralogy of the WTP SW simulants is about the same for all three different BSR campaigns. Sodalite (from the halides) is a major phase and the sulfate sodalite known as nosean is a minor phase since there is less sulfate than halides in this waste simulant. Nepheline is a major phase and lowcarnegeite is a minor phase in the Fall 2009 WTP SW BSR campaign and the Spring 2011 WTP SW BSR simulant samples appear to have less low-carnegeite than the Fall 2010 simulant campaign, which has none. At this time there does not seem to be a correlation to REDOX and the appearance of carnegieite in some, but not all, spectra is being investigated as the appearance of carnegieite is only based on relative peak heights, which are not as accurate as area under the peak measurements. Quantitative analysis of phase pure nepheline is under consideration as the phase pure standards already exist.

The predictions and the observed phases in the WTP SW radioactive product are the same with sodalite (shown as ' $\mathrm{S}$ ') being a major phase for the halides and nepheline (shown as 'Ne') the second most abundant phase and some nosean (shown as 'N') (see Figure 30). The XRD overlay shown in Figure 30 also demonstrates that the same phases are found in the non-radioactive engineering scale bed products, in the BSR simulant products, and in the BSR radioactive products.

As with the simulant monolith to simulant granular product XRD comparisons, the crystal structure distribution for the radioactive monolith was similar to the radioactive granular product used to form the monoliths (see Table 35). 
Table 35. Mineral Phases Analyzed in FBSR Products

\begin{tabular}{|c|c|c|c|c|}
\hline & $\begin{array}{c}\text { Low- } \\
\text { Carnegieite } \\
\text { Nominally } \\
\mathrm{NaAlSiO}_{4}\end{array}$ & $\begin{array}{c}\text { Nepheline } \\
\text { Nominally } \\
\mathrm{NaAlSiO}_{4} \text { or } \\
\mathrm{K}_{0.25} \mathrm{Na}_{0.75} \mathrm{AlSiO}_{4}\end{array}$ & $\begin{array}{c}\text { Nosean } \\
\mathrm{Na}_{6}\left[\mathrm{Al}_{6} \mathrm{Si}_{6} \mathrm{O}_{24}\right]\left(\mathrm{Na}_{2}\right. \\
\left.\mathrm{SO}_{4}\right) \text { and } / \text { or } \\
\text { Sodalite } \\
\mathrm{Na}_{6}\left[\mathrm{Al}_{6} \mathrm{Si}_{6} \mathrm{O}_{24}\right](2 \mathrm{Na} \\
\mathrm{X} \text { where } \mathrm{X}=\mathrm{Cl}, \mathrm{F}, \mathrm{I})\end{array}$ & $\begin{array}{l}\text { Other Minor } \\
\text { Components }\end{array}$ \\
\hline \multicolumn{5}{|c|}{ HANFORD ENVELOPE “C” LAW WASTES (2002) $\mathrm{Fe}^{+2} / \Sigma \mathrm{Fe}$ of Bed $=0.15$} \\
\hline SCT02-098-FM & & $\mathrm{X}$ & $\mathrm{Y}$ & $\mathrm{Al}_{2} \mathrm{O}_{3}, \mathrm{Fe}_{2} \mathrm{O}_{3}, \mathrm{Fe}_{3} \mathrm{O}_{4}$ \\
\hline Fines PR-01 & $\mathrm{X}$ & $\mathrm{X}$ & $\mathrm{Y}$ & $\mathrm{Al}_{2} \mathrm{O}_{3}, \mathrm{Fe}_{2} \mathrm{O}_{3}, \mathrm{Fe}_{3} \mathrm{O}_{4}$ \\
\hline \multicolumn{5}{|c|}{ HANFORD ENVELOPE “A” LAW WASTES (2004) $\mathrm{Fe}^{+2} / \Sigma \mathrm{Fe}$ of Bed = 0.28-0.81 } \\
\hline Bed 1103 & $\mathrm{X}$ & $\mathrm{X}$ & $\mathrm{Y}$ & $\mathrm{TiO}_{2}$ \\
\hline Bed 1104 & $\mathrm{X}$ & $\mathrm{X}$ & $\mathrm{Y}$ & $\mathrm{TiO}_{2}$ \\
\hline Fines 1125 & $\mathrm{X}$ & $\mathrm{Y}$ & & $\mathrm{TiO}_{2}$ \\
\hline \multicolumn{5}{|c|}{ INL SBW WASTES (2003-4) $\mathrm{Fe}^{+2} / \Sigma \mathrm{Fe}$ of Bed $=0.51-0.61$} \\
\hline Bed 260 & $\mathrm{Y}$ & $\mathrm{X}$ & TR & $\mathrm{Al}_{2} \mathrm{O}_{3}$ and $\mathrm{TiO}_{2}$ \\
\hline Bed 272 & $\mathrm{Y}$ & $\mathrm{X}$ & TR & $\mathrm{TiO}_{2}$ \\
\hline Bed 277 & $\mathrm{Y}$ & $\mathrm{X}$ & TR & $\mathrm{TiO}_{2}$ \\
\hline Bed 1173 & & $\mathrm{X}$ & TR & $\begin{array}{c}\mathrm{Al}_{2} \mathrm{O}_{3}, \mathrm{SiO}_{2} \\
\mathrm{NaAl}_{11} \mathrm{O}_{17} \\
(\mathrm{Ca}, \mathrm{Na}) \mathrm{SiO}_{3}\end{array}$ \\
\hline \multicolumn{5}{|c|}{ HANFORD RASSAT LAW WASTES $(2008) \mathrm{Fe}^{+2} / \Sigma \mathrm{Fe}$ of $\mathrm{Bed}=0.41-0.90$} \\
\hline PR Bed Product $5274(\mathrm{P} 1 \mathrm{~A})$ & $\mathrm{Y}$ & $\mathrm{X}$ & $\mathrm{X}$ & $\mathrm{Al}_{2} \mathrm{O}_{3}$, \\
\hline PR Bed Product $5316(\mathrm{P} 1 \mathrm{~A})$ & $\mathrm{Y}$ & $\mathrm{X}$ & $\mathrm{X}$ & Pyrophyllite* \\
\hline HTF Fines $5280(\mathrm{P} 1 \mathrm{~A})$ & $\mathrm{X}$ & $\mathrm{Y}$ & & $\begin{array}{c}\mathrm{NaAl}_{11} \mathrm{O}_{17} \\
\text { (Diaoyudaoite), } \mathrm{TiO}_{2}\end{array}$ \\
\hline HTF Fines 5297 (P1A) & $\mathrm{X}$ & $\mathrm{Y}$ & $\bar{X}$ & $\mathrm{SiO}_{2}$ \\
\hline PR Bed Product 5359 (P1B) & $\mathrm{Y}$ & $\mathrm{X}$ & $\mathrm{X}$ & Pyrophyllite* \\
\hline PR Bed Product 5372 (P1B) & $\mathrm{Y}$ & $\mathrm{X}$ & $\mathrm{X}$ & Pyrophyllite* \\
\hline HTF Fines 5351 (P1B) & $\mathrm{X}$ & $\mathrm{Y}$ & $\mathrm{Y}$ & $\mathrm{SiO}_{2}$ \\
\hline HTF Fines 5357 (P1B) & $\mathrm{X}$ & $\mathrm{Y}$ & $\mathrm{Y}$ & $\mathrm{TiO}_{2}$ \\
\hline Composite (P1A) & $\mathrm{X}$ & $\mathrm{Y}$ & $\mathrm{Y}$ & $\mathrm{SiO}_{2}$ and $\mathrm{TiO}_{2}$ \\
\hline Composite (P1B) & $\mathrm{X}$ & $\mathrm{Y}$ & $\mathrm{Y}$ & $\mathrm{SiO}_{2}$ and $\mathrm{TiO}_{2}$ \\
\hline \multicolumn{5}{|c|}{ HANFORD MELTER OFF-GAS RECYCLE (WTP SW) WASTES (2008) $\mathrm{Fe}^{+2} / \Sigma \mathrm{Fe}=0.41-0.90$} \\
\hline PR 5475 (P2A) & $\mathrm{Y}$ & $\mathrm{Y}$ & $\mathrm{X}$ & Pyrophyllite* \\
\hline HTF Fines $5471(\mathrm{P} 2 \mathrm{~A})$ & $\mathrm{X}$ & $\mathrm{X}$ & $\mathrm{X}$ & $\mathrm{SiO}_{2}$ \\
\hline PR $5522(\mathrm{P} 2 \mathrm{~B})$ & $\mathrm{Y}$ & $\mathrm{Y}$ & $\mathrm{X}$ & Pyrophyllite*, $\mathrm{TiO}_{2}$ \\
\hline HTF Fines $5520(\mathrm{P} 2 \mathrm{~B})$ & $\mathrm{X}$ & $\mathrm{X}$ & $\mathrm{X}$ & $\mathrm{SiO}_{2}$ and $\mathrm{TiO}_{2}$ \\
\hline Composite (P2B) & $\mathrm{Y}$ & $\mathrm{X}$ & $\mathrm{X}$ & $\mathrm{SiO}_{2}$ \\
\hline \multicolumn{5}{|c|}{ HANFORD MELTER OFF-GAS RECYCLE (WTP SW) BSR Fe $\mathrm{F}^{+2} / \Sigma \mathrm{Fe}=$ mixed } \\
\hline Fall 2009 (REDOX $0.87-0.98)$ & $\mathrm{Y}$ & $\mathrm{X}$ & $\mathrm{X}$ & $\mathrm{SiO}_{2}$ and $\mathrm{TiO}_{2}$ \\
\hline $\begin{array}{l}\text { Fall } 2010 \\
\text { (REDOX } 0.65-0.78)\end{array}$ & & $\mathrm{X}$ & $\mathrm{X}$ & $\mathrm{SiO}_{2}$ and $\mathrm{TiO}_{2}$ \\
\hline $\begin{array}{l}\text { Spring } 2011 \\
\text { (REDOX 0.15-0.23) }\end{array}$ & $\mathrm{Y}$ & $\mathrm{X}$ & $\mathrm{X}$ & $\mathrm{SiO}_{2}$ and $\mathrm{TiO}_{2}$ \\
\hline RAD (REDOX $0.25-0.26)$ & & $\mathrm{X}$ & $\mathrm{X}$ & $\mathrm{SiO}_{2}$ \\
\hline Simulant Monolith & $\mathrm{Y}$ & $\mathrm{X}$ & $\mathrm{X}$ & $\mathrm{SiO}_{2}$ and $\mathrm{TiO}_{2}$ \\
\hline Radioactive Monolith & & $\mathrm{X}$ & $\mathrm{X}$ & $\mathrm{SiO}_{2}$ and $\mathrm{TiO}_{2}$ \\
\hline
\end{tabular}

$X=$ Major constituent; $Y=$ Minor constituent, $T R=$ trace constituent

$* \mathrm{Al}_{1.333} \mathrm{Si}_{2.667} \mathrm{O}_{6.667}(\mathrm{OH})_{1.333}$ 


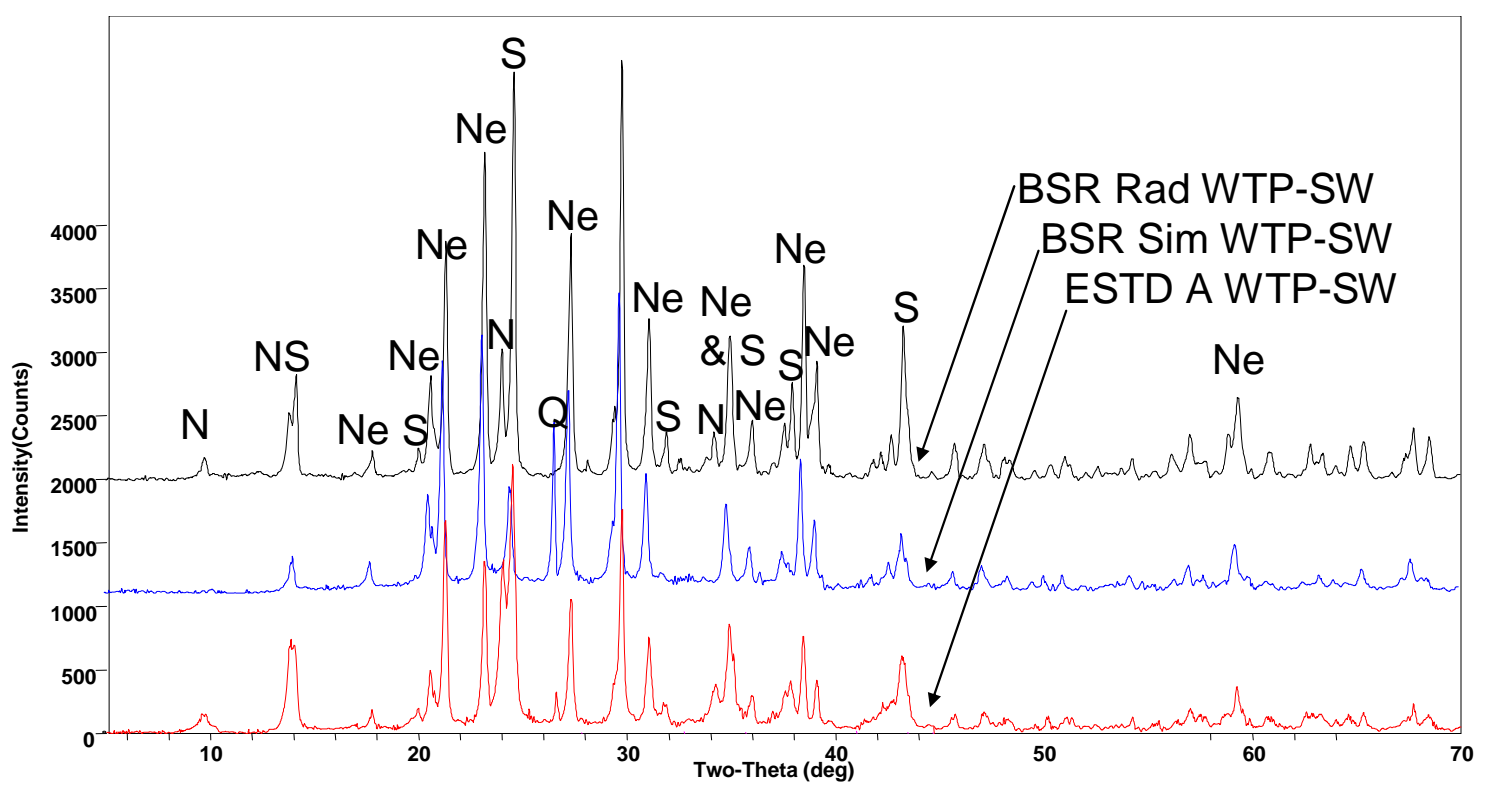

Figure 30. Comparison of mineral phases formed in non-radioactive 2008 ESTD testing of WTPSW non-radioactive BSR testing and radioactive BSR testing. In all cases the same mineral phases were observed.

\subsubsection{Composition}

The granular product chemical composition was analyzed as discussed in Section 3.1. Table 36 shows the chemical composition of the mineral granular products including the adjusted compositions determined using the measured LOI for the Simulant 1 (16.4 wt\% LOI) and Simulant 2 (9.7 wt\% LOI). These LOI values were determined from the LOI data previously shown in Table 20 and the masses of each product run from Table 21. Simulant 1 is a combination of the three separate runs performed on 8/26/09, 9/2/09, 9/8/09 and Simulant 2 is a combination of the three separate runs performed on 9/10/09, 9/15/09, 9/17/09. It should be noted that the adjusted elemental wt $\%$ values shown in Table 36 were used to normalize the PCT release values presented later in Section 4.3.3.1 of this report.

Chemical compositions including adjustments for measured LOI for the Fall 2010 and Spring 2011 BSR WTP SW simulant granular products are shown in Table 37 and Table 38, respectively. The Fall 2010 simulant BSR WTP-SW granular products were analyzed as two separate samples as shown in Table 37. We also note that the Fe and $\mathrm{Ti}$ analyses for these samples were inadvertently left off from the analytical suite so the measured Fe and Ti values from the latter Spring 2011 BSR WTP SW analyses were simply substituted into chemical composition data for the Fall 2010 samples. The LOI adjustments shown in Table 37 use previously shown Table 22 values of $4.34 \mathrm{wt} \%$ and $1.72 \mathrm{wt} \%$ for the Sim 1 and Sim 2, respectively, Only the LOI adjustments to the oxide species are shown in Table 37 since no PCT was performed on these minerals. The LOI adjustments shown in Table 38 use a measured value of $0.67 \mathrm{wt} \%$ from the tubular mixing of all five sample products previously shown in Table 24. Only the LOI adjustments to the oxide species are shown in Table 38 since no PCT was performed on these minerals. The agreement with the adjusted sum of oxides for all three of these WTP SW BSR simulant granular products shown in Table 36, Table 37 and Table 38 to the nominal accepted range of $100 \pm 5 \%$ suggests complete and accurate dissolution and chemical composition was achieved. 
Table 39 shows the chemical composition of the WTP SW radioactive granular products, including the adjusted compositions determined using an average LOI of $2.1 \mathrm{wt} \%$ from the measured LOI for the radioactive granular products previously shown in Table 22 . The adjusted elemental compositions were used for normalizing the radioactive granular product PCT results. 
Table 36. Chemical Composition of Fall 2009 WTP SW BSR Simulant Granular Product

\begin{tabular}{|c|c|c|c|c|c|c|c|c|c|c|c|c|c|c|c|}
\hline & $\begin{array}{c}\text { Sim } 1 \\
\text { Elemental } \\
\text { wt } \%\end{array}$ & & & $\begin{array}{c}\text { Sim 1 } \\
\text { Adjusted } \\
\text { Elemental } \\
\text { wt } \% \\
\end{array}$ & & $\begin{array}{c}\text { Sim } 1 \\
\text { Oxide } \\
\text { wt\% }\end{array}$ & $\begin{array}{c}\text { Sim } 1 \\
\text { Adjusted } \\
\text { Oxide } \\
\text { wt\% } \\
\end{array}$ & & $\begin{array}{c}\text { Sim } 2 \\
\text { Elemental } \\
\text { wt } \%\end{array}$ & & & $\begin{array}{c}\text { Sim } 2 \\
\text { Adjusted } \\
\text { Elemental } \\
\text { wt } \% \\
\end{array}$ & & $\begin{array}{c}\text { Sim } 2 \\
\text { Oxide } \\
\text { wt\% }\end{array}$ & $\begin{array}{c}\text { Sim } 2 \\
\text { Adjusted } \\
\text { Oxide } \\
\text { wt } \%\end{array}$ \\
\hline & Avg. Duplicate & St. Dev. & $\%$ RSD & & & & & & Avg. Duplicate & St. Dev. & $\%$ RSD & & & & \\
\hline Ag & 0.006 & 0.00 & 0.00 & 0.007 & $\mathrm{Ag}_{2} \mathrm{O}$ & 0.006 & 0.007 & Ag & 0.005 & 0.00 & 0.00 & 0.005 & $\mathrm{Ag}_{2} \mathrm{O}$ & 0.005 & 0.006 \\
\hline Al & 14.70 & 1.4E-01 & 0.01 & 17.10 & $\mathrm{Al}_{2} \mathrm{O}_{3}$ & 27.78 & 32.32 & Al & 15.50 & 0.00 & 0.00 & 17.10 & $\mathrm{Al}_{2} \mathrm{O}_{3}$ & 29.29 & 32.12 \\
\hline As & $<0.01$ & na & na & $<0.012$ & $\mathrm{As}_{2} \mathrm{O}_{3}$ & $<0.01$ & $<0.012$ & As & $<0.01$ & na & na & $<0.011$ & $\mathrm{As}_{2} \mathrm{O}_{3}$ & $<0.011$ & $<0.011$ \\
\hline B & 0.34 & $4.0 \mathrm{E}-02$ & 0.12 & 0.39 & $\mathbf{B}_{2} \mathbf{O}_{3}$ & 1.09 & 1.27 & $\mathbf{B}$ & 0.31 & $6.4 \mathrm{E}-03$ & $2.1 \mathrm{E}-02$ & 0.34 & $\mathbf{B}_{2} \mathbf{O}_{3}$ & 0.99 & 1.09 \\
\hline $\mathbf{C a}$ & 0.09 & $1.8 \mathrm{E}-03$ & 0.02 & 0.10 & $\mathrm{CaO}$ & 0.12 & 0.14 & Ca & 0.09 & $7.1 \mathrm{E}-05$ & $7.8 \mathrm{E}-04$ & 0.10 & $\mathrm{CaO}$ & 0.13 & 0.14 \\
\hline Cl & 0.53 & $7.1 \mathrm{E}-04$ & 0.00 & 0.62 & Cl & 0.53 & 0.62 & $\mathrm{Cl}$ & 0.66 & $1.4 \mathrm{E}-03$ & $2.2 \mathrm{E}-03$ & 0.72 & CI & 0.66 & 0.72 \\
\hline $\mathrm{Cr}$ & 0.08 & $4.0 \mathrm{E}-03$ & 0.05 & 0.09 & $\mathrm{Cr}_{2} \mathrm{O}_{3}$ & 0.11 & 0.13 & $\mathrm{Cr}$ & 0.09 & $5.4 \mathrm{E}-03$ & $6.1 \mathrm{E}-02$ & 0.10 & $\mathrm{Cr}_{2} \mathrm{O}_{3}$ & 0.13 & 0.14 \\
\hline Cs & 0.65 & na & na & 0.75 & $\mathrm{Cs}_{2} \mathrm{O}$ & 0.68 & 0.80 & Cs & 0.62 & na & na & 0.68 & $\mathrm{Cs}_{2} \mathrm{O}$ & 0.66 & 0.72 \\
\hline $\mathbf{F}$ & 0.20 & 0.00 & 0.00 & 0.23 & $\mathbf{F}$ & 0.20 & 0.23 & $\mathbf{F}$ & 0.12 & $1.4 \mathrm{E}-03$ & $1.2 \mathrm{E}-02$ & 0.13 & $\mathbf{F}$ & 0.12 & 0.13 \\
\hline $\mathbf{F e}$ & 0.58 & $3.2 \mathrm{E}-02$ & 0.05 & 0.68 & $\mathrm{Fe}_{2} \mathrm{O}_{3}$ & 0.83 & 0.97 & $\mathbf{F e}$ & 0.78 & $2.9 \mathrm{E}-02$ & $3.7 \mathrm{E}-02$ & 0.85 & $\mathrm{Fe}_{2} \mathrm{O}_{3}$ & 1.11 & 1.22 \\
\hline I & 0.012 & na & na & 0.014 & I & 0.012 & 0.014 & I & 0.016 & na & na & 0.017 & I & 0.016 & 0.017 \\
\hline $\mathbf{K}$ & 0.36 & $1.1 \mathrm{E}-02$ & 0.03 & 0.42 & $\mathrm{~K}_{2} \mathrm{O}$ & 0.43 & 0.50 & $\mathbf{K}$ & 0.39 & $8.5 \mathrm{E}-04$ & $2.2 \mathrm{E}-03$ & 0.42 & $\mathrm{~K}_{2} \mathrm{O}$ & 0.47 & 0.51 \\
\hline $\mathbf{M g}$ & 0.05 & $2.8 \mathrm{E}-03$ & 0.06 & 0.06 & MgO & 0.08 & 0.10 & Mg & 0.06 & $1.6 \mathrm{E}-03$ & $2.8 \mathrm{E}-02$ & 0.06 & MgO & 0.09 & 0.10 \\
\hline $\mathbf{N a}$ & 11.39 & $3.3 \mathrm{E}-01$ & 0.03 & 13.26 & $\mathrm{Na}_{2} \mathrm{O}$ & 15.36 & 17.87 & $\mathrm{Na}$ & 12.75 & $9.2 \mathrm{E}-02$ & $7.2 \mathrm{E}-03$ & 13.98 & $\mathrm{Na}_{2} \mathrm{O}$ & 17.18 & 18.84 \\
\hline $\mathbf{N i}$ & 0.01 & 0.00 & 0.00 & 0.01 & NiO & 0.01 & 0.02 & $\mathbf{N i}$ & 0.01 & 0.00 & 0.00 & 0.01 & $\mathrm{NiO}$ & 0.01 & 0.01 \\
\hline $\mathbf{P}$ & 0.06 & $1.6 \mathrm{E}-03$ & 0.03 & 0.06 & $\mathrm{PO}_{4}$ & 0.17 & 0.20 & $\mathbf{P}$ & 0.06 & $1.61 \mathrm{E}-03$ & $2.6 \mathrm{E}-02$ & 0.07 & $\mathrm{PO}_{4}$ & 0.19 & 0.21 \\
\hline $\mathbf{P b}$ & 0.07 & 0.00 & 0.00 & 0.08 & PbO & 0.07 & 0.08 & $\mathbf{P b}$ & 0.07 & 0.00 & 0.00 & 0.08 & $\mathrm{PbO}$ & 0.08 & 0.08 \\
\hline $\mathbf{R e}$ & 0.13 & na & na & 0.15 & $\mathrm{ReO}_{2}$ & 0.15 & 0.17 & $\mathbf{R e}$ & 0.12 & na & na & 0.14 & $\mathrm{ReO}_{2}$ & 0.15 & 0.16 \\
\hline S & 0.09 & 9.4E-04 & 0.01 & 0.10 & $\mathrm{SO}_{4}$ & 0.27 & 0.31 & $\mathbf{S}$ & 0.11 & $4.7 \mathrm{E}-04$ & 4.4E-03 & 0.12 & $\mathrm{SO}_{4}$ & 0.32 & 0.35 \\
\hline Si & 16.85 & $2.1 \mathrm{E}-01$ & 0.01 & 19.61 & $\mathrm{SiO}_{2}$ & 36.05 & 41.94 & $\mathbf{S i}$ & 17.85 & $7.1 \mathrm{E}-02$ & $4.0 \mathrm{E}-03$ & 19.57 & $\mathrm{SiO}_{2}$ & 38.18 & 41.87 \\
\hline $\mathbf{T i}$ & 0.67 & $1.7 \mathrm{E}-02$ & 0.03 & 0.78 & $\mathrm{TiO}_{2}$ & 1.12 & 1.31 & $\mathbf{T i}$ & 0.75 & $1.6 \mathrm{E}-02$ & $2.1 \mathrm{E}-02$ & 0.82 & $\mathrm{TiO}_{2}$ & 1.25 & 1.38 \\
\hline $\mathbf{Z n}$ & 0.09 & $6.2 \mathrm{E}-03$ & 0.07 & 0.10 & $\mathrm{ZnO}$ & 0.11 & 0.12 & $\mathbf{Z n}$ & 0.10 & $2.9 \mathrm{E}-03$ & $2.8 \mathrm{E}-02$ & 0.11 & $\mathrm{ZnO}$ & 0.13 & 0.14 \\
\hline & & & & & Sum & 85.19 & 99.12 & & & & & & Sum & 91.14 & 99.95 \\
\hline
\end{tabular}


Table 37. Chemical Composition of Fall 2010 WTP SW BSR Simulant Granular Product

\begin{tabular}{|c|c|c|c|c|c|c|c|c|c|c|c|c|c|c|c|}
\hline \multirow[b]{2}{*}{$\begin{array}{c}\text { Diss. } \\
\text { Method }\end{array}$} & & \multicolumn{3}{|c|}{ Sim 1 Combined } & & \multirow[b]{2}{*}{$\begin{array}{c}\text { Average } \\
\text { wt } \%\end{array}$} & \multirow{2}{*}{$\begin{array}{c}\text { Average } \\
\text { wt\% } \\
\text { LOI } \\
\text { Adjust }\end{array}$} & \multirow[b]{2}{*}{$\begin{array}{c}\text { Diss. } \\
\text { Method }\end{array}$} & & \multicolumn{3}{|c|}{ "Sim 2 Combined } & & \multirow[b]{2}{*}{$\begin{array}{c}\text { Average } \\
\text { wt } \%\end{array}$} & \multirow{2}{*}{$\begin{array}{c}\text { Average } \\
\text { wt\% } \\
\text { LOI } \\
\text { Adjust }\end{array}$} \\
\hline & & $\begin{array}{c}\text { Triplicate } \\
\text { Average } \\
\text { wt } \% \\
\end{array}$ & $\begin{array}{l}\text { Std. } \\
\text { Dev. }\end{array}$ & \%RSD & & & & & & $\begin{array}{c}\text { Triplicate } \\
\text { Average } \\
\text { wt } \% \\
\end{array}$ & $\begin{array}{l}\text { Std. } \\
\text { Dev. }\end{array}$ & \%RSD & & & \\
\hline AR & Ag & $<0.000010$ & na & na & $\mathrm{Ag}_{2} \mathrm{O}$ & $<0.00001$ & $<0.00001$ & $\mathbf{A R}$ & Ag & $<0.000010$ & na & na & $\mathrm{Ag}_{2} \mathrm{O}$ & $<0.00001$ & $<0.00001$ \\
\hline AR/LiTB & Al & 15.7 & 0.8 & 5.0 & $\mathrm{Al}_{2} \mathrm{O}_{3}$ & 29.71 & 31.00 & AR/LiTB & Al & 16.1 & 0.5 & 3.1 & $\mathrm{Al}_{2} \mathrm{O}_{3}$ & 30.37 & 30.90 \\
\hline $\mathbf{A R}$ & As & 0.004 & $7.1 \mathrm{E}-06$ & 0.2 & $\mathrm{As}_{2} \mathrm{O}_{3}$ & 0.005 & 0.005 & AR & As & 0.003 & 0.0004 & 10.9 & $\mathrm{As}_{2} \mathrm{O}_{3}$ & 0.005 & 0.005 \\
\hline AR & B & 0.328 & 0.0035 & 1.1 & $\mathrm{~B}_{2} \mathrm{O}_{3}$ & 1.05 & 1.10 & $\mathbf{A R}$ & B & 0.338 & 0.0028 & 0.8 & $\mathrm{~B}_{2} \mathrm{O}_{3}$ & 1.09 & 1.11 \\
\hline KOH & $\mathrm{Cl}$ & 0.58 & 0.004 & 0.6 & $\mathrm{Cl}$ & 0.58 & 0.60 & KOH & $\mathrm{Cl}$ & 0.46 & 0.01 & & $\mathrm{Cl}$ & 0.46 & 0.47 \\
\hline LiTB & $\mathrm{Cr}$ & 0.093 & 0.001 & 0.9 & $\mathrm{Cr}_{2} \mathrm{O}_{3}$ & 0.14 & 0.14 & LiTB & $\mathrm{Cr}$ & 0.098 & 0.003 & 3.0 & $\mathrm{Cr}_{2} \mathrm{O}_{3}$ & 0.14 & 0.15 \\
\hline LiTB & Cs & 0.420 & 0.005 & 1.2 & $\mathrm{Cs}_{2} \mathrm{O}$ & 0.44 & 0.46 & LiTB & Cs & 0.415 & 0.003 & 0.8 & $\mathrm{Cs}_{2} \mathrm{O}$ & 0.44 & 0.45 \\
\hline \multirow[t]{2}{*}{ KOH } & $\mathbf{F}$ & 0.20 & 0.001 & 0.7 & $\mathbf{F}$ & 0.20 & 0.21 & KOH & $\mathbf{F}$ & 0.14 & 0.001 & 0.5 & $\mathbf{F}$ & 0.14 & 0.14 \\
\hline & $\mathbf{F e}$ & 1.40 & na & na & $\mathrm{Fe}_{2} \mathrm{O}_{3}$ & 2.02 & 2.11 & & $\mathrm{Fe}$ & 1.40 & na & na & $\mathrm{Fe}_{2} \mathrm{O}_{3}$ & 2.02 & 2.05 \\
\hline KOH & I & 0.014 & 0.004 & 25.7 & I & 0.014 & 0.015 & $\mathrm{KOH}$ & I & 0.014 & 0.004 & 25.7 & I & 0.014 & 0.014 \\
\hline AR/LiTB & $\mathbf{K}$ & 0.40 & 0.03 & 8.0 & $\mathrm{~K}_{2} \mathrm{O}$ & 0.48 & 0.50 & AR/LiTB & $\mathbf{K}$ & 0.39 & 0.01 & 3.6 & $\mathrm{~K}_{2} \mathrm{O}$ & 0.46 & 0.47 \\
\hline AR/LiTB & $\mathrm{Na}$ & 12.55 & 0.8 & 6.0 & $\mathrm{Na}_{2} \mathrm{O}$ & 16.92 & 17.65 & AR/LiTB & $\mathbf{N a}$ & 12.70 & 0.4 & 3.2 & $\mathrm{Na}_{2} \mathrm{O}$ & 17.12 & 17.41 \\
\hline AR & $\mathrm{Ni}$ & 0.0016 & 0.00005 & 3.0 & $\mathrm{NiO}$ & 0.002 & 0.002 & AR & $\mathrm{Ni}$ & 0.0016 & 0.0000 & 3.0 & $\mathrm{NiO}$ & 0.002 & 0.002 \\
\hline $\mathbf{A R}$ & $\mathbf{P}$ & 0.072 & 0.0011 & 1.5 & $\mathbf{P O}_{4}$ & 0.22 & 0.230 & $\mathbf{A R}$ & $\mathbf{P}$ & 0.075 & 0.0007 & 0.9 & $\mathrm{PO}_{4}$ & 0.23 & 0.234 \\
\hline AR & $\mathbf{P b}$ & 0.0014 & 0.0001 & 11.0 & $\mathrm{PbO}$ & 0.001 & 0.002 & $\mathbf{A R}$ & $\mathbf{P b}$ & 0.0014 & 0.0000 & 1.0 & $\mathrm{PbO}$ & 0.002 & 0.002 \\
\hline AR & $\mathbf{R e}$ & 0.0674 & 0.004 & 5.6 & $\mathrm{ReO}_{2}$ & 0.08 & 0.08 & $\mathbf{A R}$ & $\mathbf{R e}$ & 0.0674 & 0.0038 & 5.6 & $\mathrm{ReO}_{2}$ & 0.08 & 0.08 \\
\hline AR/LiTB & $\mathbf{S}$ & 0.076 & 0.01 & 11 & $\mathrm{SO}_{4}$ & 0.23 & 0.24 & AR/LiTB & $\mathbf{S}$ & 0.113 & 0.01 & 10 & $\mathrm{SO}_{4}$ & 0.34 & 0.34 \\
\hline \multirow[t]{2}{*}{ LiTB } & $\mathbf{S i}$ & 18.5 & 0.071 & 0.4 & $\mathrm{SiO}_{2}$ & 39.47 & 41.18 & LiTB & $\mathbf{S i}$ & 18.8 & 0.000 & 0.0 & $\mathrm{SiO}_{2}$ & 40.22 & 40.91 \\
\hline & $\mathbf{T i}$ & 0.9 & na & na & $\mathrm{TiO}_{2}$ & 1.50 & 1.57 & & $\mathbf{T i}$ & 0.9 & na & na & $\mathrm{TiO}_{2}$ & 1.50 & 1.53 \\
\hline \multirow[t]{3}{*}{ AR/LiTB } & $\mathbf{Z n}$ & 0.103 & 0.005 & 4.7 & $\mathrm{ZnO}$ & 0.13 & 0.13 & AR/LiTB & $\mathbf{Z n}$ & 0.108 & 0.00 & 1.9 & $\mathrm{ZnO}$ & 0.13 & 0.14 \\
\hline & & & & & & Sum & Sum & & & & & & & Sum & Sum \\
\hline & & & & & & 93.18 & 97.23 & & & & & & & 94.77 & 96.40 \\
\hline
\end{tabular}


Table 38. Chemical Composition of Spring 2010 WTP SW BSR Simulant Granular Product

\begin{tabular}{|c|c|c|c|c|c|c|c|}
\hline $\begin{array}{c}\text { Diss. } \\
\text { Method }\end{array}$ & & $\begin{array}{c}\text { Average } \\
\text { wt } \%\end{array}$ & Std. Dev. & $\%$ RSD & & $\begin{array}{c}\text { Average } \\
\text { wt } \%\end{array}$ & $\begin{array}{c}\text { LOI Adjusted } \\
\text { Average } \\
\text { wt } \%\end{array}$ \\
\hline $\mathbf{A R}$ & Ag & $<0.0021$ & na & na & $\mathrm{Ag}_{2} \mathrm{O}$ & $<0.002$ & $<0.002$ \\
\hline $\mathbf{A R} / \mathbf{P F}$ & Al & 16.80 & 0.5 & 2.9 & $\mathrm{Al}_{2} \mathrm{O}_{3}$ & 31.74 & 31.96 \\
\hline $\mathbf{A R}$ & As & 0.0006 & na & na & $\mathbf{A s}_{2} \mathbf{O}_{3}$ & 0.001 & 0.001 \\
\hline $\mathbf{A R} / \mathbf{P F}$ & B & 0.33 & 0.01 & 3.9 & $\mathrm{~B}_{2} \mathbf{O}_{3}$ & 1.05 & 1.06 \\
\hline $\mathbf{A R} / \mathbf{P F}$ & Ba & 0.01 & 0.002 & 15 & $\mathrm{BaO}$ & 0.02 & 0.02 \\
\hline $\mathbf{A R}$ & $\mathbf{C a}$ & 0.22 & 0.05 & 21 & $\mathrm{CaO}$ & 0.31 & 0.31 \\
\hline AR & Cd & $<0.001$ & na & na & $\mathrm{CdO}$ & $<0.001$ & $<0.001$ \\
\hline $\mathbf{A R}$ & $\mathrm{Ce}$ & $<0.01$ & na & na & $\mathrm{CeO}_{2}$ & $<0.013$ & $<0.013$ \\
\hline $\mathrm{KOH}$ & Cl & na & na & na & Cl & 0.30 & 0.30 \\
\hline PF & $\mathrm{Cr}$ & 0.088 & 0.002 & 2.5 & $\mathrm{Cr}_{2} \mathrm{O}_{3}$ & 0.13 & 0.13 \\
\hline $\mathbf{A R}$ & Cs & 0.014 & 0.001 & 4.4 & $\mathrm{Cs}_{2} \mathrm{O}$ & 0.01 & 0.01 \\
\hline $\mathbf{A R}$ & $\mathbf{C u}$ & 0.0042 & 0.0004 & 11 & $\mathrm{CuO}$ & 0.01 & 0.01 \\
\hline KOH & $\mathbf{F}$ & na & na & na & $\mathbf{F}$ & $<0.10$ & $<0.101$ \\
\hline AR/PF & $\mathbf{F e}$ & 1.4 & 0.11 & 7.7 & $\mathrm{Fe}_{2} \mathrm{O}_{3}$ & 2.02 & 2.03 \\
\hline KOH & I & na & na & na & I & 0.0052 & 0.0052 \\
\hline $\mathbf{A R}$ & $\mathbf{K}$ & 0.37 & 0.01 & 2.8 & $\mathrm{~K}_{2} \mathrm{O}$ & 0.45 & 0.45 \\
\hline $\mathbf{A R}$ & La & 0.0041 & 0.0005 & 11 & $\mathrm{La}_{2} \mathrm{O}_{3}$ & 0.005 & 0.005 \\
\hline $\mathbf{A R}$ & $\mathbf{L i}$ & 0.01 & 0.001 & 16 & $\mathbf{L i}_{2} \mathbf{O}$ & 0.011 & 0.011 \\
\hline $\mathbf{A R} / \mathbf{P F}$ & Mg & 0.1 & 0.01 & 18 & MgO & 0.11 & 0.11 \\
\hline $\mathbf{A R}$ & Mn & 0.002 & 0.00003 & 1.8 & $\mathrm{MnO}_{2}$ & 0.002 & 0.002 \\
\hline $\mathbf{A R}$ & Mo & $<0.002$ & na & na & $\mathrm{MoO}_{3}$ & 0.004 & 0.004 \\
\hline $\mathbf{A R}$ & $\mathbf{N a}$ & 14.23 & 3.21 & 22.6 & $\mathrm{Na}_{2} \mathrm{O}$ & 19.19 & 19.31 \\
\hline $\mathbf{A R}$ & $\mathbf{N i}$ & 0.0033 & 0.0012 & 36.7 & $\mathrm{NiO}$ & 0.004 & 0.004 \\
\hline $\mathrm{AR}$ & $\mathbf{P}$ & 0.08 & 0.03 & 37.5 & $\mathrm{PO}_{4}$ & 0.26 & 0.26 \\
\hline $\mathbf{A R}$ & $\mathbf{P b}$ & 0.01 & 0.0001 & 1.5 & $\mathbf{P b O}$ & 0.009 & 0.009 \\
\hline AR/PF & $\mathbf{R e}$ & 0.05 & 0.0041 & 8.7 & $\mathrm{ReO}_{2}$ & 0.055 & 0.06 \\
\hline AR & $\mathbf{S}$ & 0.16 & 0.0026 & 1.7 & $\mathrm{SO}_{4}$ & 0.48 & 0.48 \\
\hline PF & Si & 19.13 & 0.2 & 1.1 & $\mathrm{SiO}_{2}$ & 40.93 & 41.20 \\
\hline AR & Sn & $<0.003$ & na & na & $\mathrm{SnO}_{2}$ & $<0.004$ & $<0.004$ \\
\hline AR/PF & $\mathrm{Sr}$ & 0.010 & 0.0007 & 7.7 & SrO & 0.01 & 0.01 \\
\hline PF & $\mathbf{T i}$ & 0.899 & 0.01 & 0.9 & $\mathrm{TiO}_{2}$ & 1.50 & 1.51 \\
\hline AR & $\mathbf{V}$ & 0.010 & 0.0005 & 4.9 & $\mathrm{~V}_{2} \mathrm{O}_{5}$ & 0.01 & 0.01 \\
\hline AR/PF & $\mathbf{Z n}$ & 0.106 & 0.01 & 11 & $\mathrm{ZnO}$ & 0.13 & 0.13 \\
\hline AR & $\mathbf{Z r}$ & 0.006 & 0.0009 & 16 & $\mathrm{ZrO}_{2}$ & 0.01 & 0.01 \\
\hline & & & & & Sum & 98.87 & 99.53 \\
\hline
\end{tabular}


Table 39. Chemical Composition of WTP SW Radioactive Granular Product

\begin{tabular}{|c|c|c|c|c|c|c|c|c|}
\hline Selected & & Combined & & & \multirow{3}{*}{$\begin{array}{c}\text { Average } \\
\text { wt } \% \\
\text { LOI Adjust Elemental }\end{array}$} & & \multirow{3}{*}{$\begin{array}{c}\text { Average } \\
\text { wt } \%\end{array}$} & \multirow{3}{*}{$\begin{array}{c}\text { Average } \\
\text { wt } \%\end{array}$} \\
\hline Diss. & & Average & Std. Dev. & $\%$ RSD & & & & \\
\hline Method & & wt\% & & & & & & \\
\hline & & & & & & & & LOI Adjust Oxide \\
\hline $\mathbf{A R}$ & Ag & $<0.0014$ & na & na & $<0.001$ & $\mathrm{Ag}_{2} \mathrm{O}$ & $<0.001$ & $<0.001$ \\
\hline $\mathrm{AR} / \mathrm{PF}$ & Al & 15.22 & 0.16 & 1.1 & 15.53 & $\mathrm{Al}_{2} \mathrm{O}_{3}$ & 28.75 & 29.35 \\
\hline $\mathbf{A R} / \mathbf{P F}$ & B & 0.49 & 0.01 & 1.9 & 0.50 & $\mathrm{~B}_{2} \mathrm{O}_{3}$ & 1.58 & 1.61 \\
\hline AR/PF & $\mathbf{B a}$ & 0.013 & 0.001 & 4.7 & 0.01 & BaO & 0.01 & 0.01 \\
\hline $\mathbf{A R}$ & Cd & $<0.00061$ & na & na & $<0.001$ & $\mathrm{CdO}$ & $<0.001$ & $<0.001$ \\
\hline AR & $\mathrm{Ce}$ & $<0.013$ & na & na & $<0.013$ & $\mathrm{CeO}_{2}$ & $<0.027$ & $<0.028$ \\
\hline KOH & $\mathrm{Cl}$ & 1.07 & 0.03 & 3.07 & 1.09 & $\mathrm{Cl}$ & 1.07 & 1.09 \\
\hline PF & $\mathrm{Cr}$ & 0.13 & 0.01 & 4.5 & 0.13 & $\mathrm{Cr}_{2} \mathrm{O}_{3}$ & 0.18 & 0.19 \\
\hline $\mathbf{A R}$ & $\mathrm{Cu}$ & $<0.0020$ & na & na & $<0.002$ & $\mathrm{CuO}$ & 0.00 & 0.00 \\
\hline КОН & $\mathbf{F}$ & 1.11 & 0.04 & 3.59 & 1.13 & $\mathbf{F}$ & 1.11 & 1.13 \\
\hline $\mathrm{AR} / \mathrm{PF}$ & $\mathbf{F e}$ & 1.4 & 0.0306 & 2.1 & 1.47 & $\mathrm{Fe}_{2} \mathrm{O}_{3}$ & 2.06 & 2.10 \\
\hline AR & $\mathbf{K}$ & 0.36 & 0.01 & 2.4 & 0.36 & $\mathrm{~K}_{2} \mathrm{O}$ & 0.43 & 0.44 \\
\hline $\mathbf{A R}$ & La & 0.0040 & 0.0001 & 1.8 & 0.00 & $\mathrm{La}_{2} \mathrm{O}_{3}$ & 0.00 & 0.00 \\
\hline AR & $\mathbf{L i}$ & 0.010 & 0.0003 & 2.7 & 0.01 & $\mathbf{L i}_{2} \mathbf{O}$ & 0.02 & 0.02 \\
\hline AR/PF & Mg & 0.065 & 0.001 & 1.6 & 0.07 & MgO & 0.11 & 0.11 \\
\hline AR & Mn & 0.0080 & 0.0004 & 4.7 & 0.01 & $\mathrm{MnO}_{2}$ & 0.01 & 0.01 \\
\hline AR & Mo & $<0.0031$ & na & na & $<0.003$ & $\mathrm{MoO}_{3}$ & $<0.005$ & $<0.005$ \\
\hline AR & $\mathbf{N a}$ & 17.97 & 0.15 & 0.9 & 18.34 & $\mathrm{Na}_{2} \mathrm{O}$ & 24.22 & 24.72 \\
\hline $\mathbf{A R}$ & $\mathrm{Ni}$ & 0.0054 & 0.0008 & 14 & 0.01 & $\mathrm{NiO}$ & 0.01 & 0.01 \\
\hline AR & $\mathbf{P}$ & 0.10 & 0.0035 & 3.4 & 0.10 & $\mathrm{PO}_{4}$ & 0.31 & 0.32 \\
\hline AR & $\mathbf{P b}$ & 0.0065 & 0.0004 & 6.0 & 0.01 & $\mathbf{P b O}$ & 0.01 & 0.01 \\
\hline $\mathbf{A R}$ & $\mathbf{R e}$ & 0.05 & 0.008 & 1.7 & 0.05 & $\mathrm{ReO}_{2}$ & 0.06 & 0.06 \\
\hline AR & $\mathbf{S}$ & 0.17 & 0.01 & 3.4 & 0.18 & $\mathrm{SO}_{4}$ & 0.52 & 0.53 \\
\hline PF & Si & 18.05 & 0.10 & 0.6 & 18.43 & $\mathrm{SiO}_{2}$ & 38.61 & 39.42 \\
\hline AR & Sn & $<0.0031$ & na & na & $<0.003$ & $\mathrm{SnO}_{2}$ & $<0.004$ & $<0.004$ \\
\hline AR & $\mathrm{Sr}$ & 0.0081 & 0.0001 & 1.3 & 0.01 & SrO & 0.01 & 0.01 \\
\hline $\mathbf{A R}$ & $\mathbf{Z r}$ & 0.013 & 0.0003 & 2.0 & 0.01 & $\mathrm{ZrO}_{2}$ & 0.02 & 0.02 \\
\hline AR & ${ }^{137} \mathrm{Cs}$ & $2.1 \mathrm{E}-05$ & $4.7 \mathrm{E}-07$ & 2.2 & $2.2 \mathrm{E}-05$ & $\mathrm{Cs}_{2} \mathrm{O}$ & $2.3 \mathrm{E}-05$ & $2.3 \mathrm{E}-05$ \\
\hline PF & ${ }^{99} \mathrm{Tc}$ & $2.0 \mathrm{E}-03$ & $1.7 \mathrm{E}-04$ & 8.5 & $2.0 \mathrm{E}-03$ & $\mathrm{TcO}_{2}$ & $2.3 \mathrm{E}-03$ & $2.4 \mathrm{E}-03$ \\
\hline Direct & ${ }^{129} \mathrm{I}$ & $1.4 \mathrm{E}-03$ & $2.0 \mathrm{E}-04$ & 13.6 & $1.5 \mathrm{E}-03$ & ${ }^{129} \mathrm{I}$ & $1.4 \mathrm{E}-03$ & $1.5 \mathrm{E}-03$ \\
\hline Direct & ${ }^{125} \mathrm{I}$ & $8.4 \mathrm{E}-11$ & $1.2 \mathrm{E}-11$ & 14.3 & $8.6 \mathrm{E}-11$ & ${ }^{125} \mathrm{I}$ & $8.4 \mathrm{E}-11$ & $8.5 \mathrm{E}-11$ \\
\hline & & & & & & & Sum & Sum \\
\hline & & & & & & & 100.79 & 102.89 \\
\hline
\end{tabular}


SRNL-STI-2011-00331

Revision 0

\subsubsection{Durability Testing}

\subsubsection{PCT Results}

Duplicate PCT testing was performed on each of the original Fall 2009 WTP SW BSR simulant granular product run composites, Simulant 1 (combination of the three 8/26/09, 9/2/09, 9/8/09 runs) and Simulant 2 (combinations of the three 9/10/09, 9/15/09, 9/17/09 runs). The average and standard deviation PCT test results are shown in Table 40. Standard deviations were calculated from the replicate data using the Excel spreadsheet 'STDEV' function. Leachate concentrations were adjusted for elemental composition via Equation 1 (see Section 3.8.1) to obtain normalized concentrations ( $g_{\text {waste }}$ form $/$ Lleachant) and then adjusted for the BET SA via Equation 2 (see Section 3.8.1) to obtain normalized release values in units of gwaste form $/ \mathrm{m}^{2}$. In the early Fall 2009 tests the BET SA was determined on the PCT 100/200 mesh powders without pre-roasting of the samples to remove any residual carbon $(16.7 \mathrm{wt} \%$ for Simulant 1 and $9.7 \mathrm{wt} \%$ for Simulant 2). The presence of this much residual coal could explain the relatively high measured BET SAs for these materials in the range of 78 to $123 \mathrm{~m}^{2} / \mathrm{g}$. Accordingly, data shown in Table 40 was normalized using an average of BSR granular product roasted BET SA of $3.87 \mathrm{~m}^{2} / \mathrm{g}$ [49]. PSD data measured on the PCT-prepared powders are shown in Figure 31 along with the peak particle size of 114 microns. These data along with the measured particle density of $2.5 \mathrm{~g} / \mathrm{cc}$ give a calculated geometric surface area of $0.02 \mathrm{~m}^{2} / \mathrm{g}$.

Table 40. PCT Data for Fall 2009 WTP SW Simulant Granular Product

\begin{tabular}{|l|c|c|c|c|c|c|c|c|}
\hline \multicolumn{1}{|c|}{$\mathbf{g} / \mathbf{m}^{\mathbf{2}}$} & Al & Cs & I & Na & Re & S & Si & pH \\
\hline Avg. Sim BSR 1 & $2.1 \mathrm{E}-03$ & $1.8 \mathrm{E}-02$ & $3.6 \mathrm{E}-03$ & $7.5 \mathrm{E}-03$ & $1.8 \mathrm{E}-02$ & $1.2 \mathrm{E}-01$ & $2.7 \mathrm{E}-04$ & 9.83 \\
\hline St. Dev. & $4.0 \mathrm{E}-05$ & $6.9 \mathrm{E}-04$ & $6.5 \mathrm{E}-05$ & $2.7 \mathrm{E}-04$ & $6.2 \mathrm{E}-05$ & $1.4 \mathrm{E}-03$ & $3.3 \mathrm{E}-06$ & 0.03 \\
\hline Avg. Sim BSR 2 & $2.1 \mathrm{E}-03$ & $1.4 \mathrm{E}-02$ & $2.2 \mathrm{E}-03$ & $6.9 \mathrm{E}-03$ & $1.8 \mathrm{E}-02$ & $1.3 \mathrm{E}-01$ & $2.8 \mathrm{E}-04$ & 9.82 \\
\hline St. Dev. & $3.0 \mathrm{E}-06$ & $0.0 \mathrm{E}+00$ & $2.1 \mathrm{E}-05$ & $1.1 \mathrm{E}-04$ & $1.3 \mathrm{E}-04$ & $2.6 \mathrm{E}-03$ & $1.6 \mathrm{E}-07$ & 0.00 \\
\hline
\end{tabular}



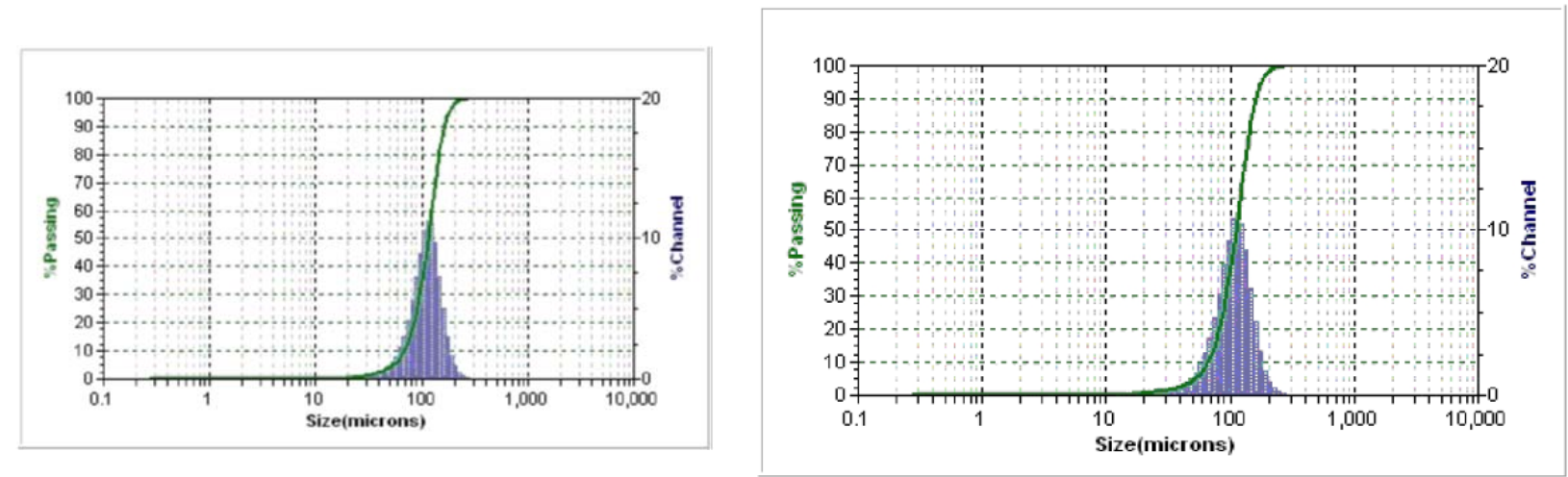

\begin{tabular}{|c|c|}
\hline \%Tile & Size(um) \\
\hline 10.00 & 68.77 \\
\hline 16.00 & 79.53 \\
\hline 25.00 & 91.07 \\
\hline 40.00 & 106.0 \\
\hline 50.00 & 114.9 \\
\hline 60.00 & 124.1 \\
\hline 70.00 & 134.1 \\
\hline 75.00 & 139.7 \\
\hline 90.00 & 164.9 \\
\hline 95.00 & 182.0 \\
\hline
\end{tabular}

(a) BSR Simulant A 1

\begin{tabular}{|c|c|}
\hline$\%$ Tile & Size(um) \\
\hline 10.00 & 66.25 \\
\hline 16.00 & 76.64 \\
\hline 25.00 & 87.89 \\
\hline 40.00 & 102.5 \\
\hline 50.00 & 111.4 \\
\hline 60.00 & 120.6 \\
\hline 70.00 & 130.7 \\
\hline 75.00 & 136.4 \\
\hline 90.00 & 161.8 \\
\hline 95.00 & 179.5 \\
\hline
\end{tabular}

(b) BSR Simulant A 2

Figure 31. Particle Size Distribution for Fall 2009 BSR PCT Powders

Triplicate PCT testing was performed on the WTP SW radioactive Fall 2010 BSR granular products. PCT test results from the triplicate tests are shown in Table 41 for the radioactive granular product. Leachate concentrations were adjusted for elemental composition via Equation 1 to obtain normalized concentrations ( $g_{\text {waste }}$ form/Lleachant) and then adjusted for the BET SA via Equation 2 to obtain normalized release values in units of $\mathrm{g}_{\text {waste }}$ form $/ \mathrm{m}^{2}$. The BET SA measured for the WTP SW radioactive granular product PCT powders (roasted) were much lower $\left(1.1 \mathrm{~m}^{2} / \mathrm{g}\right.$ ) compared to previous simulant granular product BET SAs (not roasted) in the range of 78 to $123 \mathrm{~m}^{2} / \mathrm{g}$. The observed $1.1 \mathrm{~m}^{2} / \mathrm{g}$ BET SA value for the roasted radioactive granular product is suspect low bias perhaps from the difficulty of remote preparation and handling leading to the powder preparation for the BET SA measurement. Accordingly, as was done with the simulant PCT data, data shown in Table 41 were normalized using an average of BSR granular product roasted BET SA of $3.87 \mathrm{~m}^{2} / \mathrm{g}$.

No release is reported for non-radioactive Cs in the radioactive granular product since no non-radioactive ${ }^{133} \mathrm{Cs}$ was shimmed into the feed. The radioactive iodide isotopes were not detectable in the radioactive granular product PCT leachates. 
Table 41. PCT Results for WTP SW BSR Radioactive Granular Product

\begin{tabular}{|l|c|c|c|c|c|c|c|c|}
\hline \multicolumn{1}{|c|}{$\mathbf{g} / \mathbf{m}^{\mathbf{2}}$} & $\mathbf{A l}$ & $\mathbf{C s}$ & $\mathbf{I}$ & $\mathbf{N a}$ & $\mathbf{R e}$ & $\mathbf{S}$ & $\mathbf{S i}$ & $\mathbf{p H}$ \\
\hline Avg. Rad GP & $3.1 \mathrm{E}-03$ & NA & $8.4 \mathrm{E}-04$ & $4.4 \mathrm{E}-02$ & $2.4 \mathrm{E}-02$ & $1.3 \mathrm{E}-02$ & $6.9 \mathrm{E}-04$ & 10.95 \\
\hline St. Dev. & $1.9 \mathrm{E}-04$ & NA & $5.3 \mathrm{E}-05$ & $3.2 \mathrm{E}-04$ & $1.7 \mathrm{E}-03$ & $2.3 \mathrm{E}-03$ & $8.0 \mathrm{E}-05$ & 0.03 \\
\hline & ${ }^{137} \mathrm{Cs}$ & ${ }^{99} \mathrm{Tc}$ & & ${ }^{129} \mathrm{I}$ & & ${ }^{125} \mathrm{I}$ & & \\
\hline Avg. Rad GP & $3.2 \mathrm{E}-02$ & $2.2 \mathrm{E}-02$ & $<$ & $8.0 \mathrm{E}-03$ & $<$ & $1.7 \mathrm{E}-02$ & & \\
\hline St. Dev. & $2.1 \mathrm{E}-03$ & $7.3 \mathrm{E}-04$ & & NA & & NA & & \\
\hline
\end{tabular}

PSD data measured on the PCT-prepared powders are shown in Figure 32 along with the peak particle size of $\sim 118$ microns. These data along with the measured particle density of $2.56 \mathrm{~g} / \mathrm{cc}$ give a calculated geometric surface area of $0.020 \mathrm{~m}^{2} / \mathrm{g}$.

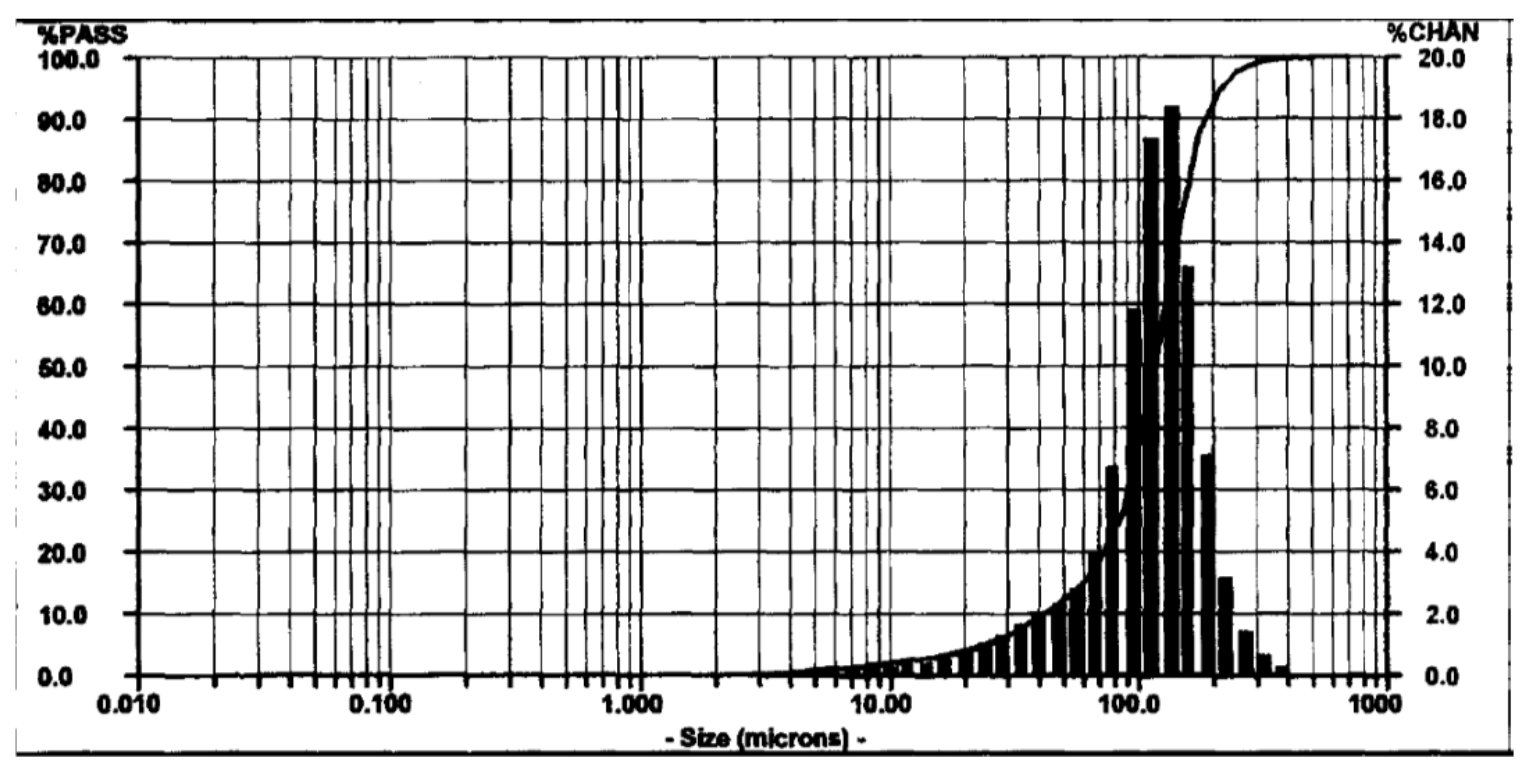

Rad A Granular Product (roasted) 100 to 200 Mesh

Percentiles:

$10 \% 42.42$

$20 \% 74.99$

$30 \% 93.66$

$40 \% 106.8$

$\mathbf{5 0 \%} \mathbf{1 1 8 . 1}$

$60 \% 129.6$

$70 \% \quad 142.2$

$80 \% \quad 158.7$

$90 \% 185.8$

$95 \% 214.8$

Figure 32. Particle Size Distribution for WTP SW Radioactive Granular Product PCT Powders (roasted) 
SRNL-STI-2011-00331

Revision 0

\subsubsection{TCLP Results}

Samples from the Fall 2009 WTP SW simulant and Spring 2011 radioactive granular products were sent to the offsite certified laboratory for TCLP and the results are shown in Table 42. Due to the limited quantity of the available BSR material, only 10 gram duplicate samples of the simulant granular product and a $\sim 3$ gram single sample of the radioactive granular product were tested. Having not shimmed in the metals $\mathrm{Sb}, \mathrm{Ba}, \mathrm{Cd}$, Se and Tl, these species were not requested in the simulant granular product TCLP. The $\mathrm{Zn}$ analysis was also inadvertently not requested. All other metals shown for the simulant granular product do pass the UTS limits. It is not clear how the Ba species gives detectable concentration in the TCLP since it was not added in the simulant. The only other source of Ba could be either the clay or coal additions that were added to the BSR slurry feed.

TCLP results shown in Table 42 indicate that the radioactive granular product passes TCLP for all elements except for $\mathrm{Cr}$ and $\mathrm{Zn}$. The radioactive granular product was produced at a much lower REDOX of $\sim 0.26$ vs. the earlier simulant granular product from the Fall 2009 campaign that had a REDOX in the range of 0.87 to 0.98 . The behavior of Cr on TCLP testing is known to be REDOX sensitive, with $\mathrm{Cr}$ in higher oxidation state, e.g., +6 , being more leachable $[10,49]$. Ongoing BSR testing within SRNL is investigating the use of a mixed oxide iron compound catalyst as an insoluble spinel host for $\mathrm{Cr}$ [25]. One explanation for the failure on $\mathrm{Zn}$ could be the excessive remote handling of the granular product in the SRNL SC using brass ( $\mathrm{Cu} / \mathrm{Zn}$ containing) sieves. For instance, nodules of $\mathrm{Cu}$ and $\mathrm{Zn}$ from the brass sieves have been observed previously in unpublished SEM scans of glass powders prepared for PCT.

These TCLP data for the BSR granular product and monolith compare favorably to the previous HRI ESTD FBSR WTP-SW granular product (shown in Table 42) and GEO-7 monoliths which only showed failure for the excess shimmed $\mathrm{Sb}$ in the granular product [22]. 
Table 42. TCLP Data for WTP SW Fall 2009 Simulant and Spring Radioactive Granular Products

\begin{tabular}{|c|c|c|c|c|c|c|c|c|}
\hline & $\begin{array}{l}\text { Shim } \\
\text { Factor }\end{array}$ & $\begin{array}{c}\text { Engineering } \\
\text { Scale } \\
\text { Simulant } \\
\text { granular } \\
\text { Shimmed }\end{array}$ & $\begin{array}{c}\text { BSR } \\
\text { Simulant } \\
\text { granular } \\
\text { (Duplicate } \\
\text { tests) } \\
\text { Not } \\
\text { Shimmed * }\end{array}$ & $\begin{array}{c}\text { BSR } \\
\text { Radioactive } \\
\text { granular } \\
\text { (Single Test) } \\
\text { Not } \\
\text { Shimmed }\end{array}$ & $\begin{array}{l}\text { REPORT } \\
\text { LIMIT } \\
\text { (RL) }\end{array}$ & $\begin{array}{l}\text { METHOD } \\
\text { DETECT } \\
\text { LIMIT } \\
\text { (MDL) }\end{array}$ & $\begin{array}{c}\text { TCLP } \\
\text { Characteristic } \\
\text { of Toxicity } \\
\text { 40CFR 261.24 }\end{array}$ & $\begin{array}{c}\text { UTS } \\
\text { 40CFR } \\
\text { 268.48(Non- } \\
\text { waste water } \\
\text { std) }\end{array}$ \\
\hline & & (mg/L) & $(\mathrm{mg} / \mathrm{L})$ & $(\mathrm{mg} / \mathrm{L})$ & $(\mathrm{mg} / \mathrm{L})$ & $(\mathrm{mg} / \mathrm{L})$ & $(\mathrm{mg} / \mathrm{L})$ & $(\mathrm{mg} / \mathrm{L})$ \\
\hline $\mathrm{Sb}$ & $48 X$ & 1.61 & $\begin{array}{c}\text { (not } \\
\text { analyzed) }\end{array}$ & $<\mathrm{MDL}$ & 0.1 & 0.03 & -- & 1.15 \\
\hline As & & $<$ MDL & $<\mathrm{MDL}$ & $<\mathrm{MDL}$ & 0.15 & 0.05 & 5 & 5 \\
\hline $\mathrm{Ba}$ & $42 X$ & ${ }^{\mathrm{J}} 0.021$ & $\begin{array}{c}\text { (not } \\
\text { analyzed) }\end{array}$ & ${ }^{\mathrm{J}} 0.0355$ & 0.05 & 0.01 & 100 & 21 \\
\hline $\mathrm{Cd}$ & 129 & ${ }^{\mathrm{J}} 0.0122$ & $\begin{array}{c}\text { (not } \\
\text { analyzed) }\end{array}$ & ${ }^{\mathrm{J}} 0.0391$ & 0.05 & 0.01 & 1 & 0.11 \\
\hline $\mathrm{Cr}$ & & 0.0708 & $\begin{array}{l}0.0203- \\
0.0414 \mathrm{~J}\end{array}$ & 9.15 & 0.05 & 0.02 & 5 & 0.6 \\
\hline $\mathrm{Pb}$ & $100 X$ & $<\mathrm{MDL}$ & $<\mathrm{MDL}$ & ${ }^{\mathrm{J}} 0.067$ & 0.1 & 0.025 & 5 & 0.75 \\
\hline $\mathrm{Se}$ & $16 X$ & 0.285 & $\begin{array}{c}\text { (not } \\
\text { analyzed) }\end{array}$ & $<\mathrm{MDL}$ & 0.15 & 0.05 & 1 & 5.7 \\
\hline $\mathrm{Ag}$ & $1000 \mathrm{X}$ & $<\mathrm{MDL}$ & $<$ MDL & $<\mathrm{MDL}$ & 0.05 & 0.01 & 5 & 0.14 \\
\hline $\mathrm{Hg}$ & & $<\mathrm{MDL}$ & $\begin{array}{c}\text { (not } \\
\text { analyzed) }\end{array}$ & $<\mathrm{MDL}$ & 0.002 & 0.0003 & 0.2 & 0.025 \\
\hline $\mathrm{Ni}$ & $100 X$ & 0.0573 & $\begin{array}{c}0.0463- \\
0.111 \\
\end{array}$ & 0.11 & 0.05 & 0.01 & -- & 11 \\
\hline $\mathrm{Tl}$ & $29 X$ & $<\mathrm{MDL}$ & $\begin{array}{c}\text { (not } \\
\text { analyzed) }\end{array}$ & $<\mathrm{MDL}$ & 0.2 & 0.05 & -- & 0.2 \\
\hline $\mathrm{Zn}$ & & ${ }^{\mathrm{J}} 0.0305$ & $\begin{array}{c}\text { (not } \\
\text { analyzed) }\end{array}$ & 11.7 & 0.1 & 0.02 & -- & 4.3 \\
\hline
\end{tabular}

J Analyte is present at a concentration above the MDL but less than the RL.

* RCRA and UTS metals Ba, Cd, Tl, Se and Sb were not added to WTP SW simulant for BSR testing.

\subsection{Monolith Testing}

\subsubsection{Radioactive Monolith Compression Testing}

The radioactive 1 " $\mathrm{x} 2$ " monolith and the 0.5 " x 1 " monolith cylinders were successfully fabricated on June 14, 2011. The monoliths were allowed to cure in the plastic molds for 28 days and then removed from the molds and transferred out of the $\mathrm{SC}$ up to a radiochemical laboratory for compression testing. The 1" $\mathrm{x}$ 2" monolith was double-bagged and transferred from the SRNL SC up to a radiochemical laboratory for compression testing on July 20, 2011 to determine the 36-day compressive strength. The 1" x 2" cylinder was intact up to $3270 \mathrm{lbs}$, giving a compressive strength of $4161 \mathrm{psi}$, well above the $500 \mathrm{psi}$ criterion required for the Hanford IDF.

\subsubsection{Composition}

Triplicate PCT testing was performed on the monolith made with the Spring 2011 WTP SW simulant granular product. Table 43 shows the chemical composition of the monolith made with the Spring 2011 WTP SW simulant granular product, including the adjusted compositions determined using the measured LOI for the monolith (7.92\%) as well as the calculated adjustment based on sum of oxides normalization. The adjusted elemental compositions using the average wt $\% 100 \%$ oxide normalization were used in the PCT calculations. 
Table 43. Chemical Composition of WTP SW Spring 2011 Monolith

\begin{tabular}{|c|c|c|c|c|c|c|c|c|c|c|}
\hline $\begin{array}{c}\text { Diss. } \\
\text { Method }\end{array}$ & & $\begin{array}{c}\text { Combined } \\
\text { Average } \\
\text { wt } \%\end{array}$ & $\begin{array}{l}\text { Std. } \\
\text { Dev. }\end{array}$ & $\%$ RSD & $\begin{array}{c}\text { Average } \\
\text { wt } \% \\
\text { LOI } \\
\text { Adjust }\end{array}$ & $\begin{array}{c}\text { Average } \\
\text { wt } \% \\
100 \% \\
\text { Oxide } \\
\text { Normalize }\end{array}$ & & $\begin{array}{c}\text { Combined } \\
\text { Average } \\
\text { wt } \%\end{array}$ & $\begin{array}{c}\text { LOI } \\
\text { Adjust } \\
\text { wt\% }\end{array}$ & $\begin{array}{c}100 \% \text { Oxide } \\
\text { Normalize } \\
\text { wt } \%\end{array}$ \\
\hline $\mathrm{AR}$ & Ag & $<0.002$ & na & na & $<0.0023$ & $<0.0025$ & $\mathrm{Ag}_{2} \mathrm{O}$ & $<0.002$ & $<0.002$ & $<0.003$ \\
\hline $\mathrm{AR} / \mathrm{PF}$ & Al & 12.07 & 0.06 & 0.5 & 13.02 & 14.21 & $\mathrm{Al}_{2} \mathrm{O}_{3}$ & 22.8 & 24.61 & 26.85 \\
\hline AA & As & 0.0006 & $1.9 \mathrm{E}-05$ & 3.2 & 0.0006 & 0.0007 & $\mathrm{As}_{2} \mathrm{O}_{3}$ & 0.001 & 0.001 & 0.001 \\
\hline $\mathrm{AR} / \mathrm{PF}$ & $\mathbf{B a}$ & 0.15 & 0.002 & 1 & 0.17 & 0.18 & $\mathrm{BaO}$ & 0.2 & 0.19 & 0.20 \\
\hline AR & $\mathrm{Ca}$ & 0.07 & 0.001 & 2 & 0.08 & 0.09 & $\mathrm{CaO}$ & 0.1 & 0.11 & 0.12 \\
\hline $\mathrm{AR}$ & Cd & $<0.0001$ & na & na & $<0.0001$ & $<0.0001$ & $\mathrm{CdO}$ & $<0.0001$ & $<0.0001$ & $<0.0001$ \\
\hline $\mathrm{AR}$ & $\mathrm{Ce}$ & $<0.01$ & na & na & $<0.0087$ & $<0.0095$ & $\mathrm{CeO}_{2}$ & $<0.02$ & $<0.02$ & $<0.020$ \\
\hline $\mathrm{KOH}$ & $\mathrm{Cl}$ & 0.30 & 0.06 & 20.3 & 0.32 & 0.35 & Cl & 0.30 & 0.32 & 0.35 \\
\hline $\mathrm{PF}$ & $\mathrm{Cr}$ & 0.039 & 0.001 & 1.5 & 0.04 & 0.05 & $\mathrm{Cr}_{2} \mathrm{O}_{3}$ & 0.1 & 0.06 & 0.07 \\
\hline AR & Cs & 0.014 & 0.0006 & 4.4 & 0.015 & 0.016 & $\mathrm{Cs}_{2} \mathrm{O}$ & $<0.001$ & 0.0016 & $<0.002$ \\
\hline $\mathrm{KOH}$ & $\mathbf{F}$ & $<0.1$ & na & na & $<0.1$ & $<0.1$ & $\mathbf{F}$ & $<0.10$ & $<0.11$ & $<0.118$ \\
\hline $\mathrm{AR} / \mathrm{PF}$ & $\mathbf{F e}$ & 0.8 & 0.01 & 1.7 & 0.90 & 0.98 & $\mathrm{Fe}_{2} \mathrm{O}_{3}$ & 1.2 & 1.29 & 1.41 \\
\hline $\mathrm{KOH}$ & I & 0.005 & na & na & 0.006 & 0.0061 & I & 0.0052 & 0.01 & 0.01 \\
\hline $\mathrm{AR}$ & $\mathbf{K}$ & 0.23 & 0.004 & 1.6 & 0.24 & 0.27 & $\mathrm{~K}_{2} \mathrm{O}$ & 0.3 & 0.30 & 0.32 \\
\hline $\mathrm{AR}$ & La & 0.003 & 0.0001 & 2 & 0.004 & 0.004 & $\mathrm{La}_{2} \mathrm{O}_{3}$ & 0.004 & 0.00 & 0.00 \\
\hline $\mathrm{AR}$ & $\mathbf{L i}$ & 0.01 & 0.001 & 18 & 0.01 & 0.01 & $\mathrm{Li}_{2} \mathrm{O}$ & 0.016 & 0.02 & 0.02 \\
\hline $\mathrm{AR} / \mathrm{PF}$ & Mg & 0.06 & 0.001 & 2 & 0.07 & 0.07 & MgO & 0.10 & 0.11 & 0.12 \\
\hline $\mathrm{AR}$ & Mn & 0.002 & 0.0003 & 15.1 & 0.002 & 0.002 & $\mathrm{MnO}_{2}$ & 0.003 & 0.00 & 0.00 \\
\hline AR & Mo & $<0.002$ & na & na & $<0.0026$ & $<0.0029$ & $\mathrm{MoO}_{3}$ & $<0.004$ & $<0.00$ & $<0.004$ \\
\hline AR & $\mathrm{Na}$ & 12.37 & 0.25 & 2.0 & 13.35 & 14.56 & $\mathrm{Na}_{2} \mathrm{O}$ & 16.7 & 17.99 & 19.63 \\
\hline AR & $\mathrm{Ni}$ & 0.003 & 0.0003 & 10.8 & 0.003 & 0.004 & $\mathrm{NiO}$ & 0.004 & 0.00 & 0.00 \\
\hline $\mathrm{KOH}$ & $\mathbf{P}$ & 0.051 & 0.012 & 24.2 & 0.055 & 0.060 & $\mathrm{PO}_{4}$ & 0.16 & 0.17 & 0.18 \\
\hline $\mathrm{AR}$ & $\mathbf{P b}$ & 0.003 & 0.001 & 19.2 & 0.003 & 0.004 & PbO & 0.003 & 0.00353 & 0.00 \\
\hline $\mathrm{AR} / \mathrm{PF}$ & $\mathbf{R e}$ & 0.017 & 0.001 & 4.8 & 0.018 & 0.020 & $\mathrm{ReO}_{2}$ & 0.02 & 0.02 & 0.02 \\
\hline $\mathrm{KOH}$ & $\mathbf{S}$ & 0.060 & 0.011 & 19.2 & 0.065 & 0.071 & $\mathrm{SO}_{4}$ & 0.18 & 0.19 & 0.21 \\
\hline $\mathrm{AR} / \mathrm{PF}$ & $\mathrm{Sr}$ & 0.009 & 0.0003 & 2.7 & 0.01 & 0.01 & SrO & 0.01 & 0.01 & 0.01 \\
\hline PF & $\mathbf{T i}$ & 0.572 & 0.01 & 1.0 & 0.62 & 0.67 & $\mathrm{TiO}_{2}$ & 1.0 & 1.03 & 1.12 \\
\hline $\mathrm{AR}$ & $\mathbf{V}$ & 0.006 & 0.0001 & 2.2 & 0.01 & 0.01 & $\mathrm{~V}_{2} \mathrm{O}_{5}$ & 0.01 & 0.01 & 0.01 \\
\hline $\mathrm{AR} / \mathrm{PF}$ & Zn & 0.056 & 0.0007 & 1 & 0.06 & 0.07 & $\mathrm{ZnO}$ & 0.1 & 0.08 & 0.08 \\
\hline \multirow[t]{2}{*}{$\mathrm{AR}$} & $\mathbf{Z r}$ & 0.009 & 0.001 & 13 & 0.01 & 0.01 & $\mathrm{ZrO}_{2}$ & 0.01 & 0.01 & 0.01 \\
\hline & & & & & & & Sum & 84.92 & 91.65 & 100.00 \\
\hline
\end{tabular}

Table 44 shows the chemical composition of the radioactive monolith products including the residual moisture and coal shown as the LOI adjusted data. As with the simulant monolith, adjustment of the as reported analytical data on an oxide basis for the total LOI of $9.2 \mathrm{wt} \%$ did not bring the sum of oxides up to $100 \%$. The calculated composition based on sum of oxides normalization is also shown. The adjusted elemental compositions using the average wt $\% 100 \%$ oxide normalization were used in the PCT calculations. 
Table 44. Chemical Composition of Radioactive WTP SW Monolith

\begin{tabular}{|c|c|c|c|c|c|c|c|c|c|c|}
\hline \multirow{2}{*}{$\begin{array}{c}\text { Selected } \\
\text { Diss. } \\
\text { Method }\end{array}$} & & \multirow{2}{*}{$\begin{array}{c}\text { Combined } \\
\text { Average } \\
\text { wt } \%\end{array}$} & & & \multirow[t]{2}{*}{$\begin{array}{c}\text { Average } \\
\text { wt } \% \\
\text { LOI } \\
\text { Adjust }\end{array}$} & \multirow[t]{2}{*}{$\begin{array}{c}\text { Average } \\
\text { wt } \% \\
100 \% \\
\text { Oxide } \\
\text { Normalize } \\
\end{array}$} & & \multirow[b]{2}{*}{$\begin{array}{c}\text { Average } \\
\text { wt } \%\end{array}$} & \multirow[b]{2}{*}{$\begin{array}{c}\text { Average } \\
\text { wt } \% \\
\text { LOI } \\
\text { Adjust }\end{array}$} & \multirow[b]{2}{*}{$\begin{array}{c}\text { Average } \\
\text { wt } \% \\
\text { Sum } \\
\text { Oxides } \\
\text { Normalize }\end{array}$} \\
\hline & & & $\begin{array}{l}\text { Std. } \\
\text { Dev. }\end{array}$ & $\%$ RSD & & & & & & \\
\hline $\mathbf{A R}$ & $\mathrm{Ag}$ & $<0.0011$ & na & na & $<0.001$ & $<0.001$ & $\mathrm{Ag}_{2} \mathrm{O}$ & $<0.001$ & $<0.001$ & $<0.001$ \\
\hline AR/PF & Al & 11.35 & 0.71 & 6.2 & 11.52 & 14.00 & $\mathrm{Al}_{2} \mathrm{O}_{3}$ & 21.45 & 23.42 & 26.45 \\
\hline AR/PF & B & 0.15 & 0.05 & 31.1 & 0.15 & 0.19 & $\mathrm{~B}_{2} \mathrm{O}_{3}$ & 0.49 & 0.53 & 0.60 \\
\hline AR/PF & $\mathbf{B a}$ & 0.128 & 0.005 & 4.1 & 0.13 & 0.16 & $\mathrm{BaO}$ & 0.14 & 0.16 & 0.18 \\
\hline $\mathbf{A R}$ & $\mathbf{C a}$ & 0.078 & 0.005 & 6.3 & 0.08 & 0.10 & $\mathrm{CaO}$ & 0.11 & 0.12 & 0.14 \\
\hline $\mathbf{A R}$ & Cd & $<0.00050$ & na & na & $<0.001$ & $<0.001$ & $\mathrm{CdO}$ & $<0.001$ & $<0.001$ & $<0.001$ \\
\hline $\mathbf{A R}$ & $\mathrm{Ce}$ & $<0.006$ & na & na & $<0.006$ & $<0.007$ & $\mathrm{CeO}_{2}$ & $<0.012$ & $<0.013$ & $<0.015$ \\
\hline KOH & $\mathrm{Cl}$ & 0.55 & 0.02 & 3.68 & 0.56 & 0.68 & $\mathrm{Cl}$ & 0.55 & 0.61 & 0.68 \\
\hline PF & $\mathrm{Cr}$ & 0.06 & 0.00 & 6.6 & 0.06 & 0.07 & $\mathrm{Cr}_{2} \mathrm{O}_{3}$ & 0.08 & 0.09 & 0.10 \\
\hline AR/PF & $\mathbf{C u}$ & 0.031 & na & na & 0.03 & 0.04 & $\mathrm{CuO}$ & 0.04 & 0.04 & 0.05 \\
\hline KOH & $\mathbf{F}$ & 0.26 & 0.02 & 7.11 & 0.26 & 0.32 & $\mathbf{F}$ & 0.26 & 0.28 & 0.32 \\
\hline AR/PF & $\mathbf{F e}$ & 0.85 & 0.0577 & 6.8 & 0.87 & 1.05 & $\mathrm{Fe}_{2} \mathrm{O}_{3}$ & 1.22 & 1.33 & 1.51 \\
\hline KOH & I & 0.0022 & 0.0001 & 6.0 & 0.00 & 0.00 & I & 0.0022 & 0.0024 & 0.0028 \\
\hline $\mathbf{A R}$ & $\mathbf{K}$ & 0.25 & 0.01 & 5.4 & 0.25 & 0.31 & $\mathrm{~K}_{2} \mathrm{O}$ & 0.30 & 0.33 & 0.37 \\
\hline $\mathbf{A R}$ & La & 0.0033 & 0.0002 & 6.7 & 0.00 & 0.00 & $\mathrm{La}_{2} \mathrm{O}_{3}$ & 0.00 & 0.00 & 0.00 \\
\hline AR/PF & $\mathbf{L i}$ & 0.009 & 0.0005 & 5.6 & 0.01 & 0.01 & $\mathbf{L i}_{2} \mathbf{O}$ & 0.02 & 0.02 & 0.02 \\
\hline AR/PF & Mg & 0.056 & 0.003 & 5.1 & 0.06 & 0.07 & MgO & 0.09 & 0.10 & 0.12 \\
\hline AR/PF & Mn & 0.005 & 0.0005 & 10.7 & 0.00 & 0.01 & $\mathrm{MnO}_{2}$ & 0.01 & 0.01 & 0.01 \\
\hline $\mathbf{A R}$ & $\mathrm{Na}$ & 14.00 & 1.13 & 8.0 & 14.21 & 17.27 & $\mathrm{Na}_{2} \mathrm{O}$ & 18.87 & 20.61 & 23.28 \\
\hline $\mathbf{A R}$ & $\mathbf{N i}$ & 0.0098 & 0.0062 & 63 & 0.01 & 0.01 & $\mathrm{NiO}$ & 0.01 & 0.01 & 0.02 \\
\hline КОН & $\mathbf{P}$ & 0.042 & 0.0003 & 0.6 & 0.046 & 0.052 & $\mathrm{PO}_{4}$ & 0.13 & 0.14 & 0.16 \\
\hline $\mathbf{A R}$ & $\mathbf{P b}$ & 0.0079 & 0.0012 & 15.7 & 0.01 & 0.01 & $\mathrm{PbO}$ & 0.01 & 0.01 & 0.01 \\
\hline $\mathbf{A R}$ & $\mathbf{R e}$ & 0.020 & 0.0005 & 2.4 & 0.022 & 0.024 & $\mathrm{ReO}_{2}$ & 0.02 & 0.03 & 0.03 \\
\hline КОH & $\mathbf{S}$ & 0.046 & 0.0035 & 7.6 & 0.050 & 0.057 & $\mathrm{SO}_{4}$ & 0.14 & 0.15 & 0.17 \\
\hline PF & $\mathbf{S i}$ & 16.90 & 1.2 & 7.2 & 17.15 & 20.84 & $\mathrm{SiO}_{2}$ & 36.15 & 39.48 & 44.59 \\
\hline $\mathbf{A R}$ & Sn & $<0.0044$ & na & na & $<0.004$ & $<0.005$ & $\mathrm{SnO}_{2}$ & $<0.006$ & $<0.006$ & $<0.007$ \\
\hline $\mathbf{A R}$ & $\mathrm{Sr}$ & 0.0058 & 0.0003 & 5.1 & 0.01 & 0.01 & SrO & 0.01 & 0.01 & 0.01 \\
\hline PF & Ti & 0.50 & 0.02 & 4.9 & 0.51 & 0.62 & $\mathrm{TiO}_{2}$ & 0.83 & 0.91 & 1.03 \\
\hline AR/PF & $\mathbf{V}$ & 0.006 & 0.000 & 5.1 & 0.01 & 0.01 & $\mathrm{~V}_{2} \mathrm{O}_{5}$ & 0.01 & 0.01 & 0.01 \\
\hline AR/PF & $\mathbf{Z n}$ & 0.07 & 0.00 & 4.9 & 0.07 & 0.08 & $\mathrm{ZnO}$ & 0.08 & 0.09 & 0.10 \\
\hline $\mathbf{A R}$ & $\mathrm{Zr}$ & 0.010 & 0.0007 & 6.8 & 0.010 & 0.012 & $\mathrm{ZrO}_{2}$ & 0.01 & 0.01 & 0.02 \\
\hline $\mathbf{A R}$ & ${ }^{137} \mathrm{Cs}$ & $9.6 \mathrm{E}-06$ & $1.9 \mathrm{E}-07$ & 1.9 & $9.8 \mathrm{E}-06$ & $1.2 \mathrm{E}-05$ & $\mathrm{Cs}_{2} \mathrm{O}$ & $1.0 \mathrm{E}-05$ & $1.1 \mathrm{E}-05$ & $1.3 \mathrm{E}-05$ \\
\hline PF & ${ }^{99} \mathrm{Tc}$ & $8.6 \mathrm{E}-04$ & $2.0 \mathrm{E}-05$ & 2.3 & $8.7 \mathrm{E}-04$ & $1.1 \mathrm{E}-03$ & $\mathrm{TcO}_{2}$ & $1.0 \mathrm{E}-03$ & $1.1 \mathrm{E}-03$ & $1.2 \mathrm{E}-03$ \\
\hline Direct & ${ }^{129} \mathrm{I}$ & $7.3 \mathrm{E}-04$ & na & na & $7.4 \mathrm{E}-04$ & $9.0 \mathrm{E}-04$ & ${ }^{129} \mathrm{I}$ & $7.3 \mathrm{E}-04$ & $7.9 \mathrm{E}-04$ & $9.0 \mathrm{E}-04$ \\
\hline Direct & ${ }^{125} \mathbf{I}$ & $2.0 \mathrm{E}-12$ & na & na & $2.1 \mathrm{E}-12$ & $2.5 \mathrm{E}-12$ & ${ }^{125} I$ & $2.0 \mathrm{E}-12$ & $2.2 \mathrm{E}-12$ & $2.5 \mathrm{E}-12$ \\
\hline & & & & & & & Sum & 81.07 & 88.54 & 100.00 \\
\hline
\end{tabular}

\subsubsection{Durability Testing}

\subsubsection{PCT Results}

Average and standard deviation PCT test results are shown in Table 45 for the simulant monolith that was made with WTP SW Spring 2011 simulant granular product and the radioactive monolith that was made with WTP SW radioactive WTP SW Fall 2010 radioactive granular product. PCT testing was performed on the crushed radioactive monolith sample that had been size reduced to the 100 to 200 mesh size by use 
of a standard tungsten blade grinder and brass sieves. Leachate concentrations were adjusted for elemental composition via Equation 1 (see Section 3.8.1) to obtain normalized concentrations (gwaste form/Lleachant) and then adjusted for the BET SA via Equation 2 (see Section 3.8.1) to obtain normalized release values in units of $g_{\text {waste form }} / \mathrm{m}^{2}$.

Table 45. PCT Data for WTP SW Spring 2011 Simulant and Radioactive Monoliths

\begin{tabular}{|l|c|c|c|c|c|c|c|r|}
\hline \multicolumn{1}{|c|}{$\mathbf{g} / \mathbf{m}^{2}$} & Al & Cs & I & Na & Re & S & Si & pH \\
\hline Avg. Simulant Monolith & $9.5 \mathrm{E}-05$ & $1.9 \mathrm{E}-04$ & $1.9 \mathrm{E}-03$ & $8.7 \mathrm{E}-03$ & $5.4 \mathrm{E}-03$ & $2.6 \mathrm{E}-02$ & $4.7 \mathrm{E}-04$ & 12.07 \\
\hline St. Dev. & $1.5 \mathrm{E}-06$ & $1.1 \mathrm{E}-05$ & $2.5 \mathrm{E}-04$ & $3.0 \mathrm{E}-04$ & $1.4 \mathrm{E}-03$ & $1.1 \mathrm{E}-03$ & $1.5 \mathrm{E}-05$ & 0.01 \\
\hline Avg. Rad Monolith & $1.2 \mathrm{E}-04$ & NA & $4.4 \mathrm{E}-04$ & $1.8 \mathrm{E}-02$ & $5.7 \mathrm{E}-03$ & $1.1 \mathrm{E}-02$ & $1.0 \mathrm{E}-03$ & 11.76 \\
\hline St. Dev. & $1.1 \mathrm{E}-05$ & NA & $3.2 \mathrm{E}-05$ & $3.4 \mathrm{E}-04$ & $4.4 \mathrm{E}-04$ & $1.7 \mathrm{E}-04$ & $9.0 \mathrm{E}-05$ & 0.05 \\
\hline & ${ }^{137} \mathrm{Cs}$ & ${ }^{99} \mathrm{Tc}$ & & ${ }^{129} \mathrm{I}$ & & ${ }^{125} \mathrm{I}$ & & \\
\cline { 1 - 7 } Avg. Rad Monolith & $1.7 \mathrm{E}-04$ & $4.6 \mathrm{E}-03$ & $<$ & $5.1 \mathrm{E}-03$ & $<$ & $8.8 \mathrm{E}-03$ & & \\
\hline St. Dev. & $2.6 \mathrm{E}-05$ & $1.2 \mathrm{E}-04$ & & NA & & NA & & \\
\hline
\end{tabular}

The BET SA measured for the Simulant A monolith PCT powders (roasted) is $21.1 \mathrm{~m}^{2} / \mathrm{g}$. PSD data measured on the PCT-prepared powders are shown in Figure 33 along with the peak particle size of $\sim 126$ microns. These data along with the measured particle density of $2.6 \mathrm{~g} / \mathrm{cc}$ give a calculated geometric surface area of $0.018 \mathrm{~m}^{2} / \mathrm{g}$.

The BET SA measured for the radioactive A monolith product PCT powders (roasted) were higher (12.6 $\mathrm{m}^{2} / \mathrm{g}$ ) compared to the radioactive A granular product BET SAs (roasted) of only $1.1 \mathrm{~m}^{2} / \mathrm{g}$, but is somewhat comparable to the roasted Simulant A monolith BET SA of $21.1 \mathrm{~m}^{2} / \mathrm{g}$. PSD data measured on the PCT-prepared powders are shown in Figure 34 along with the peak particle size of $\sim 131$ microns. These data along with the measured particle density of $2.48 \mathrm{~g} / \mathrm{cc}$ give a calculated geometric surface area of $0.018 \mathrm{~m}^{2} / \mathrm{g}$. 


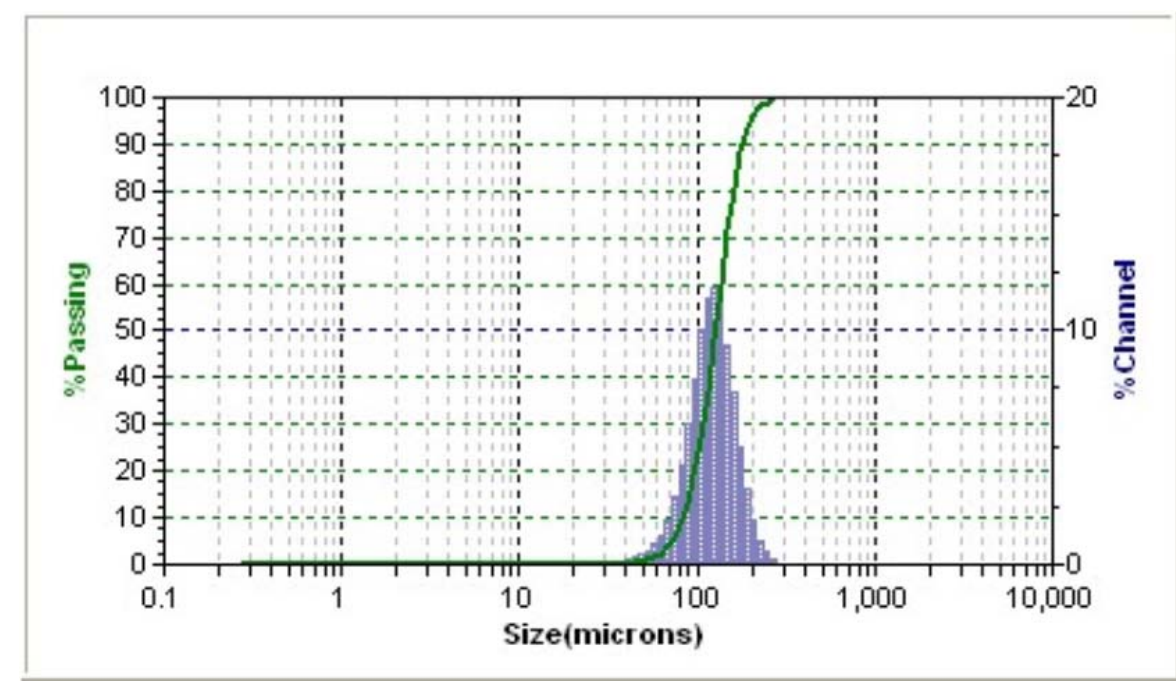
\%Tile Size(um)
10.0083 .40
$16.00 \quad 92.47$
25.00102 .9
40.00117 .1
50.00126 .2
60.00135 .7
70.00146 .6
75.00153 .0
90.00181 .6
95.00201 .5

Figure 33. Particle Size Distribution for the WTP SW Simulant Monolith PCT Powders (roasted) 


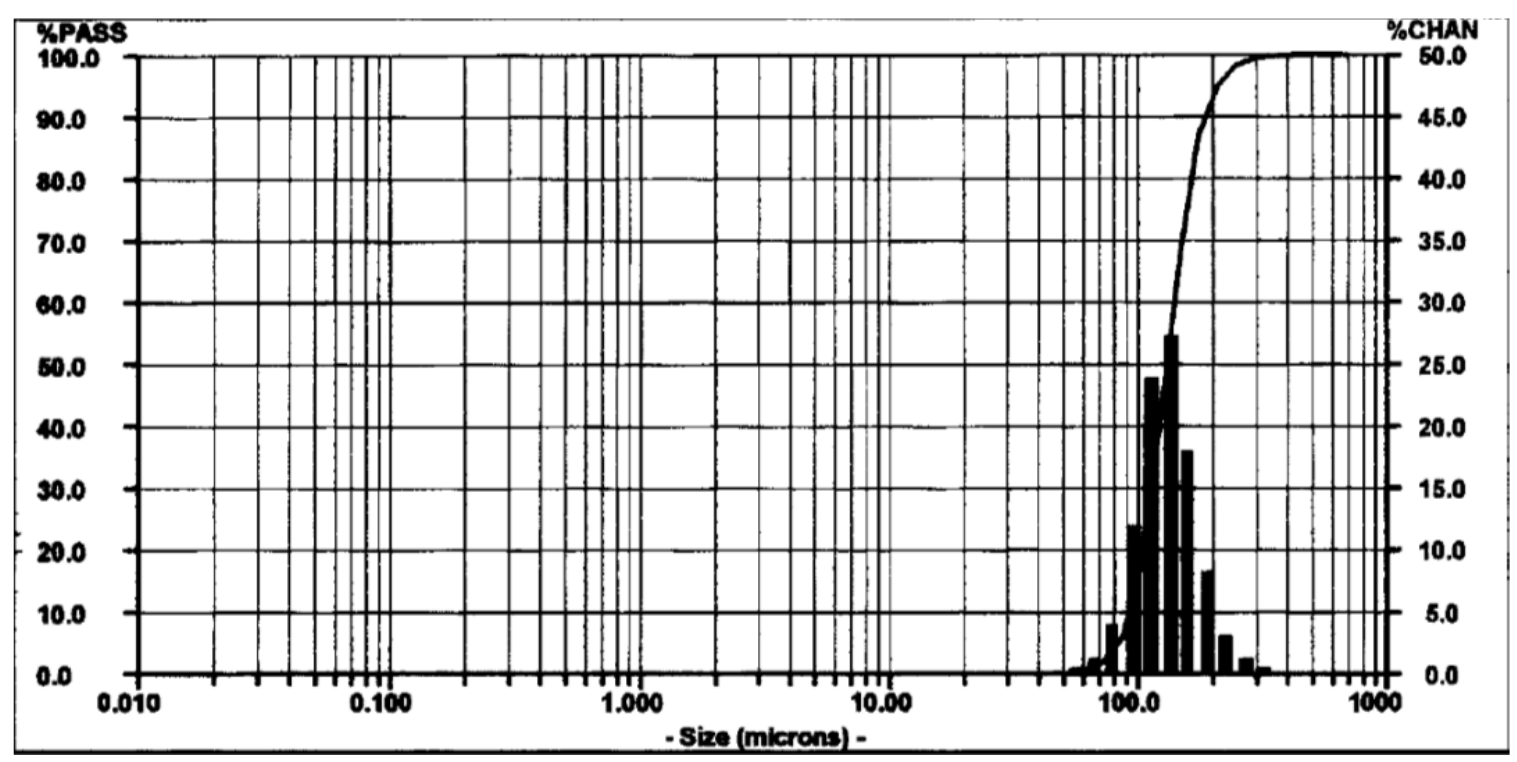

Rad A Monolith (roasted) 100 to 200 Mesh

\begin{tabular}{cc} 
Percentiles: \\
\hline $10 \%$ & 95.04 \\
$20 \%$ & 106.7 \\
$30 \%$ & 115.2 \\
$40 \%$ & 123.2 \\
$\mathbf{5 0 \%}$ & $\mathbf{1 3 1 . 1}$ \\
$60 \%$ & 139.5 \\
$70 \%$ & 149.3 \\
$80 \%$ & 162.7 \\
$90 \%$ & 184.6 \\
$95 \%$ & 207.9
\end{tabular}

Figure 34. Particle Size Distribution for the WTP SW Radioactive Monolith PCT Powders (roasted)

\subsubsection{Radioactive Monolith ASTM 1308 Testing}

The radioactive 0.5 " x 1 " cylinder monolith was leached at ambient room temperature for the specified intervals and leachate data and cumulative mass fraction leached of the various analytes are shown in Table 46. Analytical data for the radioactive monolith and the starting mass of 5.52 grams was used along with the $127 \mathrm{~mL}$ leachate volume to calculate the cumulative fraction data. The $127 \mathrm{~mL}$ of leachate used in each leach interval was calculated from the measured total surface area $\left(12.6 \mathrm{~cm}^{2}\right)$ as $10 \mathrm{X}$ the surface area. The radioactive button weighed 5.52 grams for a monolith density of $1.72 \mathrm{~g} / \mathrm{mL}$. Data shown in grey-scale in Table 46 are 'less than' detection values.

Figure 35 shows the cumulative fraction leached data traces for all measured analytes. Both $\mathrm{F}$ and $\mathrm{P}$ were higher magnitude than the other analytes as shown in the top graph. Leachate data was used to calculate the diffusivities per Equation 4 (see Section 3.8.2). These data are shown in Table 47. The degree of leaching in these tests is reflected in the diffusivity calculations - the lower the diffusivity, the lower the cumulative fraction leached. Since the LI is a negative log of the diffusivity, then the higher LI values indicate a lower leaching (more durable) monolith. A graph of the calculated leach indexes calculated per 
Equation 5 (see Section 3.8.2) is shown in Figure 36. This figure shows that the Leach Indexes for Na, $\mathrm{Re} /{ }^{99} \mathrm{Tc}$ and I are above 6, 9 and 11, respectively, after at least the 2-day leaching intervals. These are minimum LI target levels associated with the IDF at Hanford [60]. The fact that the monolith leach data provides LI values that are higher than these IDF minimum LI target levels indicates that this matrix should be acceptable to the IDF.
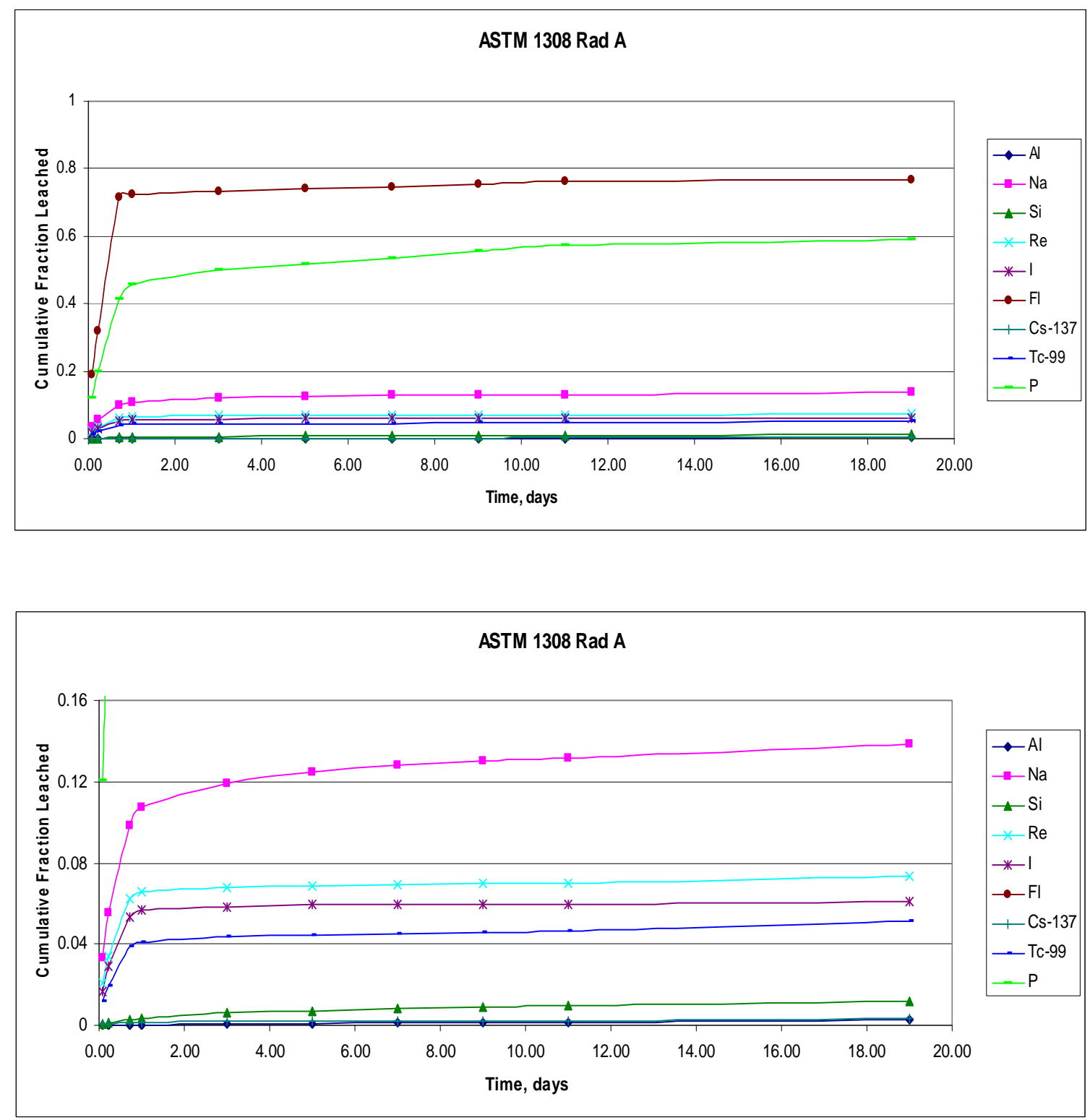

Figure 35. Cumulative Fraction Leached for Radioactive A Monolith ASTM 1308. Top Graph shows All Data; Bottom Graph Gives Expanded Scale. 
Table 46. Leachate Data for Radioactive A Monolith ASTM 1308

\begin{tabular}{|c|c|c|c|c|c|c|c|c|c|c|c|c|c|}
\hline \multirow[b]{2}{*}{ Days } & \multirow[b]{2}{*}{ Hours } & \multicolumn{4}{|c|}{ Al } & \multicolumn{4}{|c|}{$\mathrm{Na}$} & \multicolumn{4}{|c|}{$\mathbf{S i}$} \\
\hline & & $\mathbf{m g} / \mathbf{L}$ & mg & $\begin{array}{c}\text { Cumulative } \\
\text { mg }\end{array}$ & $\begin{array}{c}\text { Cumulative } \\
\text { Fraction } \\
\text { Leached } \\
\end{array}$ & mg/L & mg & $\begin{array}{c}\text { Cumulative } \\
\text { mg }\end{array}$ & $\begin{array}{c}\text { Cumulative } \\
\text { Fraction } \\
\text { Leached } \\
\end{array}$ & $\mathbf{m g} / \mathbf{L}$ & mg & $\begin{array}{c}\text { Cumulative } \\
\text { mg }\end{array}$ & $\begin{array}{c}\text { Cumulative } \\
\text { Fraction } \\
\text { Leached } \\
\end{array}$ \\
\hline & 0 & & & & 0 & & & & 0 & & & & 0 \\
\hline 0.08 & 2 & 0.132 & 0.017 & 0.017 & 0.0000 & 81.08 & 31.75 & 31.75 & 0.0333 & 5.16 & 0.66 & 0.66 & 0.0006 \\
\hline 0.21 & 5 & 0.07 & 0.009 & 0.026 & 0.0000 & 166 & 21.08 & 52.83 & 0.0554 & 4.46 & 0.57 & 1.22 & 0.0011 \\
\hline 0.71 & 17 & 0.321 & 0.041 & 0.066 & 0.0001 & 321 & 40.77 & 93.60 & 0.0982 & 18 & 2.29 & 3.51 & 0.0030 \\
\hline 1 & 24 & 0.19 & 0.024 & 0.091 & 0.0001 & 68.1 & 8.65 & 102.25 & 0.1073 & 6.34 & 0.81 & 4.31 & 0.0037 \\
\hline 3 & 72 & 2.03 & 0.258 & 0.348 & 0.0005 & 91.6 & 11.63 & 113.88 & 0.1195 & 20.2 & 2.57 & 6.88 & 0.0060 \\
\hline 5 & 120 & 1.98 & 0.251 & 0.600 & 0.0008 & 39.1 & 4.97 & 118.85 & 0.1247 & 11.2 & 1.42 & 8.30 & 0.0072 \\
\hline 7 & 168 & 2.09 & 0.265 & 0.865 & 0.0011 & 23.8 & 3.02 & 121.87 & 0.1278 & 8.18 & 1.04 & 9.34 & 0.0081 \\
\hline 9 & 216 & 1.88 & 0.239 & 1.104 & 0.0014 & 15.3 & 1.94 & 123.81 & 0.1299 & 5.99 & 0.76 & 10.10 & 0.0088 \\
\hline 11 & 264 & 1.81 & 0.230 & 1.334 & 0.0017 & 11.3 & 1.44 & 125.25 & 0.1314 & 5.24 & 0.67 & 10.77 & 0.0094 \\
\hline 19 & 456 & 7.87 & 0.999 & 2.333 & 0.0030 & 54.6 & 6.93 & 132.18 & 0.1387 & 21.7 & 2.76 & 13.52 & 0.0117 \\
\hline
\end{tabular}

\begin{tabular}{|c|c|c|c|c|c|c|c|c|c|}
\hline \multirow[b]{2}{*}{ Days } & \multirow[b]{2}{*}{ Hours } & \multicolumn{4}{|c|}{$\operatorname{Re}$} & \multicolumn{4}{|c|}{ I } \\
\hline & & $\mathrm{mg} / \mathrm{L}$ & mg & $\begin{array}{c}\text { Cumulative } \\
\text { mg }\end{array}$ & $\begin{array}{c}\text { Cumulative Fraction } \\
\text { Leached }\end{array}$ & $\mathrm{mg} / \mathrm{L}$ & mg & $\begin{array}{c}\text { Cumulative Fraction } \\
\text { Leached }\end{array}$ & $\begin{array}{c}\text { Cumulative Fraction } \\
\text { Leached }\end{array}$ \\
\hline & 0 & & & & 0 & & & & 0 \\
\hline 0.08 & 2 & 0.219 & 0.028 & 0.028 & 0.021 & 0.02020 & 0.00257 & 0.0026 & 0.017 \\
\hline 0.21 & 5 & 0.142 & 0.018 & 0.046 & 0.034 & 0.01480 & \begin{tabular}{|l|}
0.00188 \\
\end{tabular} & 0.0044 & 0.029 \\
\hline 0.71 & 17 & 0.297 & 0.038 & 0.083 & 0.062 & 0.02850 & \begin{tabular}{|l|}
0.00362 \\
\end{tabular} & 0.0081 & 0.053 \\
\hline 1 & 24 & 0.039 & 0.005 & 0.088 & 0.066 & 0.00422 & \begin{tabular}{|l|}
0.00054 \\
\end{tabular} & 0.0086 & 0.057 \\
\hline 3 & 72 & 0.023 & 0.003 & 0.091 & 0.068 & 0.00164 & \begin{tabular}{|l|}
0.00021 \\
\end{tabular} & 0.0088 & 0.058 \\
\hline 5 & 120 & 0.010 & 0.001 & 0.093 & 0.069 & 0.00150 & \begin{tabular}{|l|}
0.00019 \\
\end{tabular} & 0.0090 & 0.059 \\
\hline 7 & 168 & 0.007 & 0.001 & 0.093 & 0.069 & 0.00022 & \begin{tabular}{|l|}
0.00003 \\
\end{tabular} & 0.0090 & 0.059 \\
\hline 9 & 216 & 0.005 & 0.001 & 0.094 & 0.070 & 0.00013 & \begin{tabular}{|l|}
0.00002 \\
\end{tabular} & 0.0090 & 0.060 \\
\hline 11 & 264 & 0.004 & 0.001 & 0.095 & 0.070 & 0.00009 & 0.00001 & 0.0091 & 0.060 \\
\hline 19 & 456 & 0.036 & 0.005 & 0.099 & 0.074 & 0.00127 & 0.000161 & 0.0092 & 0.061 \\
\hline
\end{tabular}


SRNL-STI-2011-00331

Revision 0

Table 46. Leachate Data for Radioactive A Monolith ASTM 1308, continued

\begin{tabular}{|c|c|c|c|c|c|c|c|c|c|}
\hline \multirow{2}{*}{ Days } & \multirow{2}{*}{ Hours } & \multicolumn{4}{|c|}{$\mathbf{F}$} & \multicolumn{4}{|c|}{$\mathbf{P}$} \\
\hline & & $\mathbf{m g} / \mathbf{L}$ & mg & Cumulative mg & Cumulative Fraction Leached & $\mathrm{mg} / \mathrm{L}$ & mg & Cumulative mg & Cumulative Fraction Leached \\
\hline & 0 & & & & 0 & & & & 0 \\
\hline 0.08 & 2 & 26 & 3.302 & 3.302 & 0.188 & 2.2 & 0.279 & 0.279 & 0.121 \\
\hline 0.21 & 5 & 18 & 2.286 & 5.588 & 0.319 & 1.45 & 0.184 & 0.464 & 0.200 \\
\hline 0.71 & 17 & 55 & 6.985 & 12.573 & 0.718 & 3.88 & 0.493 & 0.956 & 0.413 \\
\hline 1 & 24 & 1 & 0.127 & 12.7 & 0.725 & 0.805 & 0.102 & 1.059 & 0.458 \\
\hline 3 & 72 & 1 & 0.127 & 12.827 & 0.732 & 0.771 & 0.098 & 1.156 & 0.500 \\
\hline 5 & 120 & 1 & 0.127 & 12.954 & 0.739 & 0.328 & 0.042 & 1.198 & 0.518 \\
\hline 7 & 168 & 1 & 0.127 & 13.081 & 0.747 & 0.328 & 0.042 & 1.240 & 0.536 \\
\hline 9 & 216 & 1 & 0.127 & 13.208 & 0.754 & 0.328 & 0.042 & 1.281 & 0.554 \\
\hline 11 & 264 & 1 & 0.127 & 13.335 & 0.761 & 0.328 & 0.042 & 1.323 & 0.572 \\
\hline 19 & 456 & 1 & 0.127 & 13.462 & 0.768 & 0.328 & 0.042 & 1.365 & 0.590 \\
\hline
\end{tabular}

\begin{tabular}{|c|c|c|c|c|c|c|c|c|c|}
\hline \multirow{2}{*}{ Days } & \multirow{2}{*}{ Hours } & \multicolumn{4}{|c|}{${ }^{137} \mathrm{Cs}$} & \multicolumn{4}{|c|}{${ }^{99} \mathrm{Tc}$} \\
\hline & & $\mathrm{mg} / \mathrm{L}$ & $\mathbf{m g}$ & Cumulative mg & Cumulative Fraction Leached & $\mathrm{mg} / \mathrm{L}$ & $\mathbf{m g}$ & Cumulative mg & Cumulative Fraction Leached \\
\hline & 0 & & & & 0 & & & & 0 \\
\hline 0.08 & 2 & $2.6 \mathrm{E}-06$ & $3.3 \mathrm{E}-07$ & $3.3 \mathrm{E}-07$ & 0.0005 & $5.4 \mathrm{E}-03$ & $6.8 \mathrm{E}-04$ & $6.8 \mathrm{E}-04$ & 0.012 \\
\hline 0.21 & 5 & $1.7 \mathrm{E}-06$ & $2.2 \mathrm{E}-07$ & $5.5 \mathrm{E}-07$ & 0.0008 & $3.7 \mathrm{E}-03$ & $4.7 \mathrm{E}-04$ & $1.2 \mathrm{E}-03$ & 0.020 \\
\hline 0.71 & 17 & $3.0 \mathrm{E}-06$ & $3.8 \mathrm{E}-07$ & $9.2 \mathrm{E}-07$ & 0.0014 & $8.7 \mathrm{E}-03$ & $1.1 \mathrm{E}-03$ & $2.3 \mathrm{E}-03$ & 0.039 \\
\hline 1 & 24 & $7.8 \mathrm{E}-07$ & $9.9 \mathrm{E}-08$ & $1.0 \mathrm{E}-06$ & 0.0016 & $1.1 \mathrm{E}-03$ & $1.4 \mathrm{E}-04$ & $2.4 \mathrm{E}-03$ & 0.041 \\
\hline 3 & 72 & $1.2 \mathrm{E}-06$ & $1.5 \mathrm{E}-07$ & $1.2 \mathrm{E}-06$ & 0.0018 & $1.1 \mathrm{E}-03$ & $1.4 \mathrm{E}-04$ & $2.5 \mathrm{E}-03$ & 0.043 \\
\hline 5 & 120 & $6.8 \mathrm{E}-07$ & $8.6 \mathrm{E}-08$ & $1.3 \mathrm{E}-06$ & 0.0019 & $3.6 \mathrm{E}-04$ & $4.5 \mathrm{E}-05$ & $2.6 \mathrm{E}-03$ & 0.044 \\
\hline 7 & 168 & $4.4 \mathrm{E}-07$ & $5.6 \mathrm{E}-08$ & $1.3 \mathrm{E}-06$ & 0.0020 & $4.1 \mathrm{E}-04$ & $5.2 \mathrm{E}-05$ & $2.6 \mathrm{E}-03$ & 0.045 \\
\hline 9 & 216 & $5.5 \mathrm{E}-07$ & $6.9 \mathrm{E}-08$ & $1.4 \mathrm{E}-06$ & 0.0021 & $2.7 \mathrm{E}-04$ & $3.5 \mathrm{E}-05$ & $2.7 \mathrm{E}-03$ & 0.046 \\
\hline 11 & 264 & $5.4 \mathrm{E}-07$ & $6.9 \mathrm{E}-08$ & $1.5 \mathrm{E}-06$ & 0.0022 & $2.4 \mathrm{E}-04$ & $3.0 \mathrm{E}-05$ & $2.7 \mathrm{E}-03$ & 0.046 \\
\hline 19 & 456 & $6.5 \mathrm{E}-06$ & $8.3 \mathrm{E}-07$ & $2.3 \mathrm{E}-06$ & 0.0035 & $2.3 \mathrm{E}-03$ & $2.9 \mathrm{E}-04$ & $3.0 \mathrm{E}-03$ & 0.051 \\
\hline
\end{tabular}


Table 46. Leachate Data for Radioactive A Monolith ASTM 1308, continued

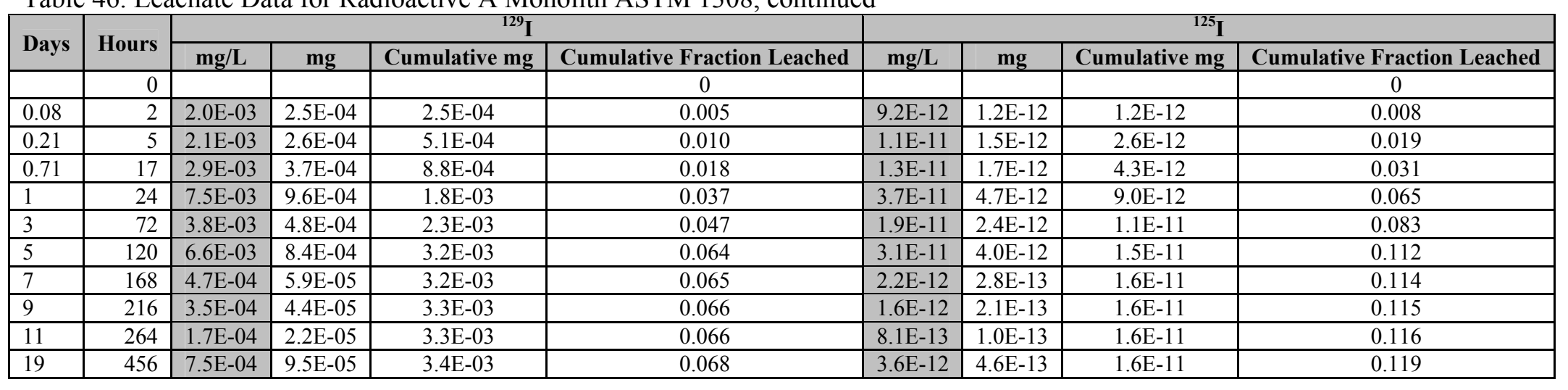


SRNL-STI-2011-00331

Revision 0

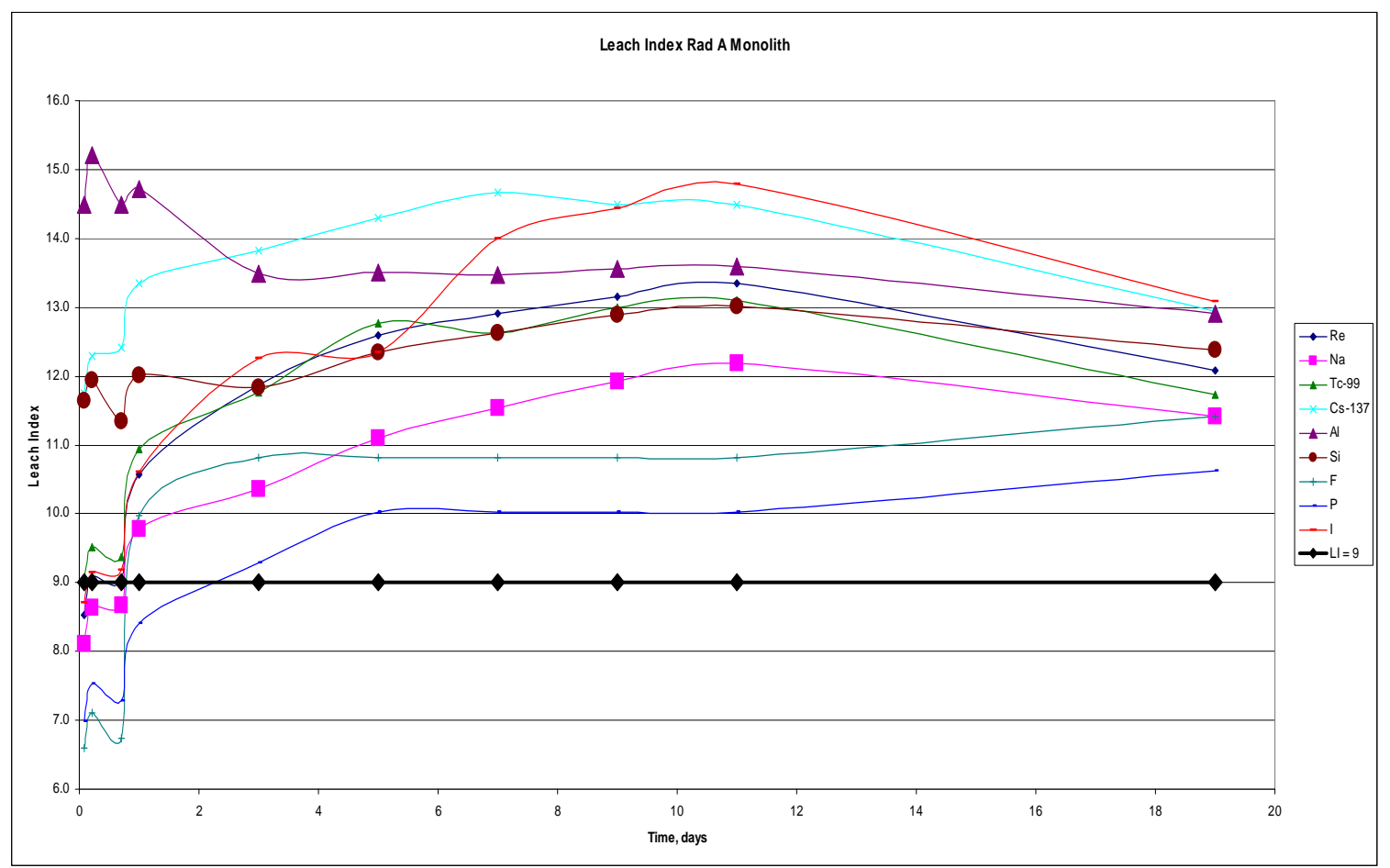

Figure 36. Calculated Leach Index Values for Radioactive A Monolith ASTM 1308 
Table 47. Calculated Diffusivities and Leach Indexes for Radioactive Monolith

\begin{tabular}{|c|c|c|c|c|c|c|c|c|c|c|}
\hline Cumutive Time & Re Diffusivity & & Na Diffusivity & & Tc-99 Diffusivity & & Cs-137 Diffusivity & & Al Diffusivity & \\
\hline (Days) & $\mathrm{cm}^{2} / \mathrm{sec}$ & Leach Index & $\mathrm{cm}^{2} / \mathrm{sec}$ & Leach Index & $\mathrm{cm}^{2} / \mathrm{sec}$ & Leach Index & $\mathrm{cm}^{2} / \mathrm{sec}$ & Leach Index & $\mathrm{cm}^{2} / \mathrm{sec}$ & Leach Index \\
\hline 0 & & & & & & & 0 & & 0 & \\
\hline 0.08 & $3.0 \mathrm{E}-09$ & 8.5 & $7.8 \mathrm{E}-09$ & 8.1 & $9.6 \mathrm{E}-10$ & 9.0 & $1.8 \mathrm{E}-12$ & 11.8 & $3.3 \mathrm{E}-15$ & 14.5 \\
\hline 0.21 & $8.3 \mathrm{E}-10$ & 9.1 & $2.3 \mathrm{E}-09$ & 8.6 & $3.0 \mathrm{E}-10$ & 9.5 & $5.1 \mathrm{E}-13$ & 12.3 & $6.2 \mathrm{E}-16$ & 15.2 \\
\hline 0.71 & $9.1 \mathrm{E}-10$ & 9.0 & $2.1 \mathrm{E}-09$ & 8.7 & $4.2 \mathrm{E}-10$ & 9.4 & $3.9 \mathrm{E}-13$ & 12.4 & $3.3 \mathrm{E}-15$ & 14.5 \\
\hline 1 & $2.7 \mathrm{E}-11$ & 10.6 & $1.6 \mathrm{E}-10$ & 9.8 & $1.2 \mathrm{E}-11$ & 10.9 & $4.6 \mathrm{E}-14$ & 13.3 & $2.0 \mathrm{E}-15$ & 14.7 \\
\hline 3 & $1.3 \mathrm{E}-12$ & 11.9 & $4.3 \mathrm{E}-11$ & 10.4 & $1.7 \mathrm{E}-12$ & 11.8 & $1.5 \mathrm{E}-14$ & 13.8 & $3.2 \mathrm{E}-14$ & 13.5 \\
\hline 7 & $1.3 \mathrm{E}-13$ & 12.9 & $2.9 \mathrm{E}-12$ & 11.5 & $2.3 \mathrm{E}-13$ & 12.6 & $2.2 \mathrm{E}-15$ & 14.7 & $3.4 \mathrm{E}-14$ & 13.5 \\
\hline 9 & $7.0 \mathrm{E}-14$ & 13.2 & $1.2 \mathrm{E}-12$ & 11.9 & $1.0 \mathrm{E}-13$ & 13.0 & $3.3 \mathrm{E}-15$ & 14.5 & $2.8 \mathrm{E}-14$ & 13.6 \\
\hline 11 & $4.5 \mathrm{E}-14$ & 13.3 & $6.6 \mathrm{E}-13$ & 12.2 & $7.9 \mathrm{E}-14$ & 13.1 & $3.2 \mathrm{E}-15$ & 14.5 & $2.6 \mathrm{E}-14$ & 13.6 \\
\hline 19 & $8.3 \mathrm{E}-13$ & 12.1 & $3.9 \mathrm{E}-12$ & 11.4 & $1.8 \mathrm{E}-12$ & 11.7 & $1.2 \mathrm{E}-13$ & 12.9 & $1.2 \mathrm{E}-13$ & 12.9 \\
\hline
\end{tabular}

\begin{tabular}{|c|c|c|c|c|c|c|c|c|}
\hline Cumutive Time & Si Diffusivity & & F Diffusivity & & P Diffusivity & & I Diffusivity & \\
\hline (Days) & $\mathrm{cm}^{2} / \mathrm{sec}$ & Leach Index & $\mathrm{cm}^{2} / \mathrm{sec}$ & Leach Index & $\mathrm{cm}^{2} / \mathrm{sec}$ & Leach Index & $\mathrm{cm}^{2} / \mathrm{sec}$ & Leach Index \\
\hline \multicolumn{9}{|l|}{0} \\
\hline 0.08 & $2.3 \mathrm{E}-12$ & 11.6 & $2.5 \mathrm{E}-07$ & 6.6 & $1.0 \mathrm{E}-07$ & 7.0 & $2.0 \mathrm{E}-09$ & 8.7 \\
\hline 0.21 & $1.1 \mathrm{E}-12$ & 11.9 & $8.0 \mathrm{E}-08$ & 7.1 & $3.0 \mathrm{E}-08$ & 7.5 & $7.2 \mathrm{E}-10$ & 9.1 \\
\hline 0.71 & $4.6 \mathrm{E}-12$ & 11.3 & $1.9 \mathrm{E}-07$ & 6.7 & $5.3 \mathrm{E}-08$ & 7.3 & $6.6 \mathrm{E}-10$ & 9.2 \\
\hline 1 & $9.8 \mathrm{E}-13$ & 12.0 & $1.1 \mathrm{E}-10$ & 10.0 & $3.9 \mathrm{E}-09$ & 8.4 & $2.5 \mathrm{E}-11$ & 10.6 \\
\hline 3 & $1.5 \mathrm{E}-12$ & 11.8 & $1.5 \mathrm{E}-11$ & 10.8 & $5.2 \mathrm{E}-10$ & 9.3 & $5.5 \mathrm{E}-13$ & 12.3 \\
\hline 5 & $4.5 \mathrm{E}-13$ & 12.4 & $1.5 \mathrm{E}-11$ & 10.8 & $9.5 \mathrm{E}-11$ & 10.0 & $4.6 \mathrm{E}-13$ & 12.3 \\
\hline 7 & $2.4 \mathrm{E}-13$ & 12.6 & $1.5 \mathrm{E}-11$ & 10.8 & $9.5 \mathrm{E}-11$ & 10.0 & $9.9 \mathrm{E}-15$ & 14.0 \\
\hline 9 & $1.3 \mathrm{E}-13$ & 12.9 & $1.5 \mathrm{E}-11$ & 10.8 & $9.5 \mathrm{E}-11$ & 10.0 & $3.6 \mathrm{E}-15$ & 14.4 \\
\hline 11 & $9.8 \mathrm{E}-14$ & 13.0 & $1.5 \mathrm{E}-11$ & 10.8 & $9.5 \mathrm{E}-11$ & 10.0 & 1.7E-15 & 14.8 \\
\hline 19 & $4.2 \mathrm{E}-13$ & 12.4 & $3.8 \mathrm{E}-12$ & 11.4 & $2.4 \mathrm{E}-11$ & 10.6 & $8.2 \mathrm{E}-14$ & 13.1 \\
\hline
\end{tabular}




\subsubsection{TCLP Results}

Samples from the Spring 2011 WTP SW simulant and radioactive monoliths were sent to the offsite certified laboratory for TCLP and the results are shown in Table 48. Due to the limited quantity of the available BSR material, a single 25 gram sample of the simulant monolith and a single $\sim 6$ gram sample of the radioactive monolith were tested.

Even though the WTP simulant monolith was made with the Spring 2011 granular product that also purposely left out the $\mathrm{Sb}, \mathrm{Ba}, \mathrm{Cd}$, Se and $\mathrm{Tl}$, all metals shown in Table 48 were analyzed for all pass the UTS limits. The radioactive monolith passed TCLP for all elements analyzed.

Table 48. TCLP Data for WTP SW Simulant and Radioactive Monoliths

\begin{tabular}{|c|c|c|c|c|c|c|}
\hline & $\begin{array}{c}\text { BSR } \\
\text { Simulant } \\
\text { monolith } \\
\text { (Single test) } \\
\text { Not Shimmed }\end{array}$ & $\begin{array}{c}\text { BSR } \\
\text { Radioactive } \\
\text { monolith } \\
\text { (Single Test) } \\
\text { Not } \\
\text { Shimmed } \\
\end{array}$ & $\begin{array}{l}\text { REPORT } \\
\text { LIMIT } \\
\text { (RI) }\end{array}$ & $\begin{array}{c}\text { METHOD } \\
\text { DETECT LIMIT } \\
\text { (MDL) }\end{array}$ & $\begin{array}{l}\text { TCLP Characteristic of } \\
\text { Toxicity 40CFR } 261.24\end{array}$ & $\begin{array}{c}\text { UTS } \\
\text { 40CFR } \\
268.48 \\
\text { (Non-waste } \\
\text { water std) }\end{array}$ \\
\hline & $(\mathrm{mg} / \mathrm{L})$ & $(\mathrm{mg} / \mathrm{L})$ & $(\mathrm{mg} / \mathrm{L})$ & $(\mathrm{mg} / \mathrm{L})$ & $(\mathrm{mg} / \mathrm{L})$ & $(\mathrm{mg} / \mathrm{L})$ \\
\hline $\mathrm{Sb}$ & $<\mathrm{MDL}$ & $<\mathrm{MDL}$ & 0.1 & 0.03 & $-\cdots$ & 1.15 \\
\hline As & 0.009 & $<\mathrm{MDL}$ & 0.15 & 0.05 & 5 & 5 \\
\hline $\mathrm{Ba}$ & 0.657 & 0.065 & 0.05 & 0.01 & 100 & 21 \\
\hline $\mathrm{Cd}$ & $<\mathrm{MDL}$ & $<\mathrm{MDL}$ & 0.05 & 0.01 & 1 & 0.11 \\
\hline $\mathrm{Cr}$ & J 0.0482 & 0.211 & 0.05 & 0.02 & 5 & 0.6 \\
\hline $\mathrm{Pb}$ & $<\mathrm{MDL}$ & $<\mathrm{MDL}$ & 0.1 & 0.025 & 5 & 0.75 \\
\hline $\mathrm{Se}$ & $<\mathrm{MDL}$ & $<$ MDL & 0.15 & 0.05 & 1 & 5.7 \\
\hline $\mathrm{Ag}$ & $<\mathrm{MDL}$ & $<$ MDL & 0.05 & 0.01 & 5 & 0.14 \\
\hline $\mathrm{Hg}$ & $<\mathrm{MDL}$ & $<$ MDL & 0.002 & 0.0003 & 0.2 & 0.025 \\
\hline $\mathrm{Ni}$ & $<\mathrm{MDL}$ & ${ }^{\mathrm{J}} 0.00980$ & 0.05 & 0.01 & $-\cdots$ & 11 \\
\hline $\mathrm{Tl}$ & $<\mathrm{MDL}$ & $<\mathrm{MDL}$ & 0.2 & 0.05 & $\ldots$ & 0.2 \\
\hline $\mathrm{Zn}$ & ${ }^{\mathrm{J}} 0.0414$ & 0.148 & 0.1 & 0.02 & $-\cdots$ & 4.3 \\
\hline
\end{tabular}

$\mathrm{J} \quad$ Analyte is present at a concentration above the MDL but less than the RL.

* RCRA and UTS metals Ba, Cd, Tl, Se and Sb were not added to Radioactive A for BSR testing. 


\subsection{Comparison of Simulant and Radioactive Testing}

Comparison of simulant BSR tests with radioactive BSR tests in this project shows that the radioactive granular products are very similar to the simulant granular products with respect to their measured REDOX, LOI and XRD. Chemical composition analyses also show that the major and minor chemical species are both qualitatively and quantitatively equivalent.

One of the key objectives for this project was to demonstrate that both the simulant and radioactive BSR products (granular products and monoliths) were similar in PCT durability testing vs. previous SRNL work related to HRI ESTD durability testing of HRI ESTD bed, fines, blends and monoliths. PCT data comparisons for the key radionuclides ${ }^{137} \mathrm{Cs},{ }^{99} \mathrm{Tc},{ }^{129} \mathrm{I}$ and ${ }^{125} \mathrm{I}$ vs. their respective simulant components $\left({ }^{133} \mathrm{Cs}\right.$, Re and $\left.{ }^{127} \mathrm{I}\right)$, indicates that in all cases the normalized releases are similar. PCT test results are shown in Table 49 for the radioactive monolith and all previous PCT data (WTP SW simulant granular product and monolith, as well as radioactive granular product).

Table 49. PCT Data for WTP SW Simulant and Radioactive Granular Product and Monoliths

\begin{tabular}{|l|c|c|c|c|c|c|c|c|}
\hline \multicolumn{1}{|c|}{ g/m $\mathbf{m}^{2}$} & $\mathbf{A l}$ & $\mathbf{C s}$ & $\mathbf{I}$ & $\mathbf{N a}$ & $\mathbf{R e}$ & $\mathbf{S}$ & $\mathbf{S i}$ & $\mathbf{p H}$ \\
\hline Avg. Sim BSR 1 & $2.1 \mathrm{E}-03$ & $1.8 \mathrm{E}-02$ & $3.6 \mathrm{E}-03$ & $7.5 \mathrm{E}-03$ & $1.8 \mathrm{E}-02$ & $1.2 \mathrm{E}-01$ & $2.7 \mathrm{E}-04$ & 9.83 \\
\hline Avg. Sim BSR 2 & $2.1 \mathrm{E}-03$ & $1.4 \mathrm{E}-02$ & $2.2 \mathrm{E}-03$ & $6.9 \mathrm{E}-03$ & $1.8 \mathrm{E}-02$ & $1.3 \mathrm{E}-01$ & $2.8 \mathrm{E}-04$ & 9.82 \\
\hline Avg. Sim Monolith & $9.5 \mathrm{E}-05$ & $1.9 \mathrm{E}-04$ & $1.9 \mathrm{E}-03$ & $8.7 \mathrm{E}-03$ & $5.4 \mathrm{E}-03$ & $2.6 \mathrm{E}-02$ & $4.7 \mathrm{E}-04$ & 12.07 \\
\hline Avg. Rad GP & $3.1 \mathrm{E}-03$ & NA & $8.4 \mathrm{E}-04$ & $4.4 \mathrm{E}-02$ & $2.4 \mathrm{E}-02$ & $1.3 \mathrm{E}-02$ & $6.9 \mathrm{E}-04$ & 10.95 \\
\hline Avg. Rad Monolith & $1.2 \mathrm{E}-04$ & NA & $4.4 \mathrm{E}-04$ & $1.8 \mathrm{E}-02$ & $5.7 \mathrm{E}-03$ & $1.1 \mathrm{E}-02$ & $1.0 \mathrm{E}-03$ & 11.76 \\
\hline & ${ }^{137} \mathbf{C s}$ & ${ }^{99} \mathbf{T c}$ & & ${ }^{129} \mathbf{I}$ & & ${ }^{125} \mathbf{I}$ & & \\
\hline Avg. Rad GP & $3.2 \mathrm{E}-02$ & $2.2 \mathrm{E}-02$ & $<$ & $8.0 \mathrm{E}-03$ & $<$ & $1.7 \mathrm{E}-02$ & & \\
\hline Avg. Rad Monolith & $1.7 \mathrm{E}-04$ & $4.6 \mathrm{E}-03$ & $<$ & $5.1 \mathrm{E}-03$ & $<$ & $8.8 \mathrm{E}-03$ & & \\
\hline
\end{tabular}

The observed $\mathrm{pH}$ values for the WTP SW simulant monolith PCT are higher than the granular product PCT. This is expected since significant amounts of highly concentrated sodium hydroxide is used in the geopolymer binder and it is possible that not all $100 \%$ of this $\mathrm{NaOH}$ completely reacts in the geopolymer formation and curing. In general, data in Table 49 indicates that the monolith normalized releases are comparable to the granular product normalized releases, specifically for the non-monolith binder elements such as $\mathrm{Cs}, \mathrm{I}, \mathrm{Re}$ and $\mathrm{S}$, which suggests certainly that the monolith process is not at all detrimental to the overall waste form performance.

As with the simulant granular product comparison to simulant monolith, we observe that the PCT leachate $\mathrm{pHs}$ for the radioactive monolith are higher than for the radioactive granular product. These trends of higher measured BET SA for monoliths compared to granular products, and higher observed pHs for PCT leachates from monoliths vs. granular products were also observed in previous SRNL testing of HRI ESTD granular products and monoliths [22].

Figure 37 shows the comparison of normalized release for previous HRI ESTD bed, fines, blends and monoliths along with the current BSR project data. This plot shows that the BSR products and monoliths give similar overall normalized release of most elements below the $0.04 \mathrm{~g} / \mathrm{m}^{2}$ value, with normalized sulfur release for previous HRI ESTD samples and the highly reduced Fall 2009 BSR simulant A granular products approaching $0.12 \mathrm{~g} / \mathrm{m}^{2}$. 


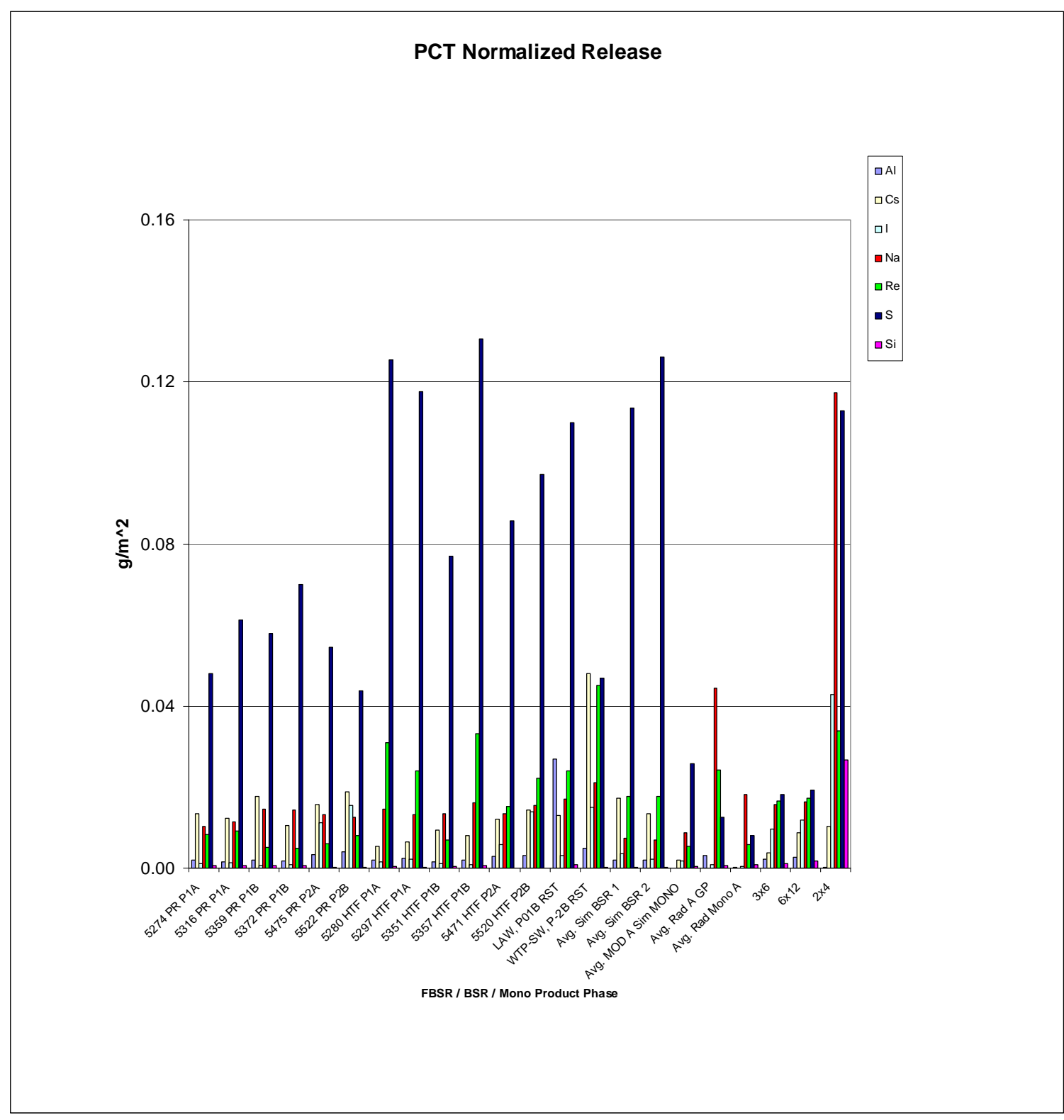

Figure 37. PCT Normalized Release for HRI ESTD Bed, Fines, Blends and Monoliths with Comparison to Current BSR Project PCT Data 
SRNL-STI-2011-00331

Revision 0

\subsection{Conclusions}

Fluidized Bed Steam Reforming (FBSR) is a robust technology for the immobilization of a wide variety of radioactive wastes, including the WTP SW stream. Applications have been demonstrated at the pilot and engineering scales for the high sodium, sulfate, halide, organic and nitrate wastes at the Hanford site, the Idaho National Laboratory (INL), and the Savannah River Site (SRS). Due to the moderate processing temperatures, halides, sulfates, and technetium are retained in mineral phases of the feldspathoid family (nepheline, sodalite, nosean, carnegieite, etc.). The feldspathoid minerals bind the contaminants such as ${ }^{99} \mathrm{Tc}$ in cage (sodalite, nosean) or ring (nepheline) structures to surrounding aluminosilicate tetrahedra in the feldspathoid structures. The granular FBSR waste form that is produced is as durable as glass based on comparison of normalized release for glass and FBSR granular product. This project has demonstrated the similarity of BSR products made with actual radioactive feeds to the previous HRI ESTD FBSR granular products. Monolithing of the BSR granular product has been shown to be feasible for WTP SW in this work using 1" $\mathrm{x} 2$ " monolith cylinders and has also previously been shown to be feasible using HRI ESTD FBSR granular product with monolith cylinders up to 6" x 12" in size [22].

Conclusions from the activities accomplished in this project are discussed below relative to the Task Activities set forth in the Task Technical and Quality Assurance Plan [61].

\section{$\underline{\text { Simulant Tasks for BSR Granular Products: }}$}

The initial task of preparing 2 Liters of WTP-SW simulant per guidance from TTT was accomplished and the analyses performed at SRNL indicate that the target analyte concentrations agreed well with analyzed data. Of special note was the decision to not add the RCRA/UTS metals Ba, Cd, Tl, Se and Sb (as had been added in the HRI ESTD tasks) per discussion with TTT. The BSR was assembled in a clean lab chemical hood and initial testing of the WTP-SW simulant was initiated using scaled parameters from the HRI ESTD testing with concurrence from TTT in the Fall of 2009. These initial tests produced enough BSR granular product to pursue durability testing (PCT and TCLP) as well as monolith fabrication. Although clay mixture and levels were determined by MINCALC ${ }^{\mathrm{TM}}$ for these runs, the coal addition levels were based on scaled parameters from the HRI ESTD runs which rendered granular product with residual coal (LOI) in the range of 8 to $17 \mathrm{wt} \%$ residual coal. Further BSR program work within SRNL that commenced in 2010 targeted a lower range of REDOX and LOI that was used in follow-on WTP-SW BSR simulant testing in the Fall of 2010 (LOI in range of $2-4 \mathrm{wt} \%$ ) and Spring $2011(\mathrm{LOI}<1 \mathrm{wt} \%)$.

Chemical composition measurements on the Fall 2009 Simulant A Batch 1 and Simulant A Batch 2 BSR granular products indicated excellent recovery of all species as the sum of oxides and sum of LOI were in the range of 100 to 101 , i.e., very close to $100 \%$. The PCT normalized release $\left(\mathrm{g} / \mathrm{m}^{2}\right)$ results were affected by high measured BET SA values in the range of 78 to $123 \mathrm{~m}^{2} / \mathrm{g}$ due to the high residual coal levels in these powders. However PCT leachate results expressed as normalized concentrations $(\mathrm{g} / \mathrm{L})$ are comparable to previous HRI ESTD WTP-SW bed, fines and blend values. By using more recent roasted BET SA values from other SRNL BSR granular product samples $\left(\sim 4 \mathrm{~m}^{2} / \mathrm{g}\right)$ in the normalized release calculations, one derives normalized release values that are very similar to previous HRI ESTD WTP-SW bed, fines and blend values. Both Fall 2009 simulant batches passed the TCLP for all elements measured by the off-site certified lab, in comparison to previous TCLP testing with HRI ESTD WTP-SW products that failed for only $\mathrm{Sb}$ due to the excessive shims of this element in the HRI ESTD simulants used [22].

Simulant Tasks for BSR Monoliths:

Page 111 of 177 
Monolithing attempts with the Fall 2009 BSR granular product were unsuccessful due to the extra water that was needed to get the recipe mixture of proper consistency to go into the curing mold. Compression tests on these initial GEO-7 fly ash based $65 \mathrm{wt} \%$ dry basis waste loaded 1" x 2" monoliths showed that they were below the minimal target of 500 psi. However, further BSR processing with WTP-SW simulant in the Fall of 2010 and Spring of 2011 that used lower total coal levels ( $\sim 1.3$ stoichiometric based on MINCALC ${ }^{\mathrm{TM}}$ ) produced enough BSR granular product to pursue further monolith activities. Even though a few scope monolith tests with longer stirring times proved successful in limited follow-on BSR granular product tests with the GEO-7 recipe, later in 2010 unsuccessful attempts were made to monolith the simulant BSR granular product from the 2010 runs using the GEO-7 fly ash geopolymer recipe even with longer stirring/contact times.

It was decided in May of 2011 to switch the monolith recipe from the fly ash basis over to the previously studied [22] clay based geopolymer monolith using a lower $42 \%$ dry basis waste loading. This new target recipe derives from the center of the region mapped out by previous literature studies for successful monoliths. The 7-day break compressive strength of this 1" x 2" monolith made with Spring 2011 BSR WTP-SW simulant was 4350 psi.

Comparison of the crystal structure of the simulant monolith with the simulant granular product indicates that the monolith binder does not produce any different crystalline structures. Chemical composition measurements on the clay geopolymer monolith post-compression testing pieces indicate that the sum of oxides and the sum of measured total LOI was only $\sim 92 \mathrm{wt} \%$. The analytical data was adjusted to a $100 \%$ sum of oxides to provide the adjusted elemental concentrations used to normalize the PCT data. Both the normalized release $\left(\mathrm{g} / \mathrm{m}^{2}\right)$ and the normalized concentrations $(\mathrm{g} / \mathrm{L})$ from PCT on the simulant monolith are comparable to previous monolith PCT data from HRI ESTD testing. The simulant monolith passed the TCLP for all elements measured by the off-site certified lab, in comparison to previous TCLP testing with HRI ESTD GEO-7 monoliths using WTP-SW products that also passed TCLP [22].

Tasks for Radioactive BSR Granular Products:

The radioactive feed consisting of DWPF OGCT was successfully received, composited and filtered in the SRNL shielded cells by remote handling. Timely analysis of the resulting filtrate served as the basis for chemical adjustment before a $20 \mathrm{X}$ concentration. Final chemical analysis of the fully concentrated and shimmed radioactive BSR feed (pre-coal) compared favorably with the WTP-SW simulant targets.

Fall 2010 radioactive BSR runs in the SRNL SC used parameters optimized from the two previous (Fall 2009 and Fall 2010) simulant runs. Process analyses of these radioactive BSR granular products (LOI, REDOX and XRD) showed that they were similar to the Fall 2010 simulant BSR granular products, and enough granular product was produced (95 grams) for subsequent granular product and monolith testing.

Chemical composition measurements on the Fall 2010 radioactive granular product indicated excellent recovery of all species as the sum of oxides and sum of LOI were in the range of 100 to $102 \mathrm{wt} \%$, i.e., very close to $100 \%$. The PCT normalized release $\left(\mathrm{g} / \mathrm{m}^{2}\right)$ results were affected by a relatively low $1 \mathrm{~m}^{2} / \mathrm{g}$ BET SA value. However PCT leachate results expressed as normalized concentrations $(\mathrm{g} / \mathrm{L})$ are comparable to previous HRI ESTD WTP-SW bed, fines and blend values. By using more recent roasted BET SA values from other SRNL BSR granular product samples $\left(\sim 4 \mathrm{~m}^{2} / \mathrm{g}\right)$ in the normalized release calculations, one derives normalized release values that are very similar to previous HRI ESTD WTP-SW bed, fines and blend values. Normalized PCT release for all radionuclides were bounded by the simulant elements used in this testing. 
SRNL-STI-2011-00331

Revision 0

The radioactive BSR granular product passed the TCLP for all elements measured by the off-site certified lab except for $\mathrm{Cr}$ and $\mathrm{Zn}$, neither of which elements were shown to fail in previous HRI ESTD TCLP testing on simulant [22]. Possible reasons for the Cr TCLP failure are suspected to be the relatively low REDOX and/or no use of the TTT mixed iron oxide catalyst, whereas the Zn failure could derive from excessive remote handling required using brass sieves in collecting the granular product remotely within the SRNL SC.

\section{Tasks for Radioactive BSR Monoliths:}

The radioactive 1" x 2" monolith was successfully formed with the clay geopolymer recipe and had measured 36-day compression break of 4161 psi. Chemical composition of the radioactive monolith showed similar behavior as the simulant monolith in that the sum of analyzed oxides and measured total LOI only added to $\sim 88 \mathrm{wt} \%$ and $\sim 91 \mathrm{wt} \%$, respectively, so the $100 \%$ normalized oxide chemical compositions were used in normalizing both the PCT and the ASTM 1308 monolith leach test data. These data suggests that the LOI measurements were biased low, i.e., not all the moisture and/or residual carbon was removed from heat treatment of the crushed monolith pieces during successive drying from $105^{\circ} \mathrm{C}$ up through $525^{\circ} \mathrm{C}$.

Both the normalized release $\left(\mathrm{g} / \mathrm{m}^{2}\right)$ and the normalized concentrations $(\mathrm{g} / \mathrm{L})$ from PCT on the radioactive monolith are comparable to previous simulant monolith PCT data from HRI ESTD testing. As was seen with the radioactive granular products vs. simulant granular products, comparison of radioactive monolith PCT data with simulant monolith PCT data indicates that all normalized release for radionuclides were similar to their simulant counterpart elements.

Finally the radioactive monolith leach tests performed under the ASTM C1308 protocol show that the calculated Leach Indexes for key elements such as $\mathrm{Na},{ }^{99} \mathrm{Tc} / \mathrm{Re}$ and I are all above listed Leach Index minimums for these COCs with respect to potential disposal of immobilized waste into the IDF at Hanford. 
SRNL-STI-2011-00331

Revision 0

BLANK PAGE

Page 114 of 177 
SRNL-STI-2011-00331

Revision 0

\subsection{Recommendations, Path Forward or Future Work}

The ART project supporting the work reported for this project is ending. However, ongoing BSR research at SRNL addresses several of the findings from this WTP SW project and other recent BSR LAW campaigns within SRNL that were started back in October of 2010 [24,25]. Current BSR testing with simulants of high sulfate and high Cr actual Hanford LAW waste is aimed at determining the effect of the mixed oxide iron compound on the fate of $\mathrm{Cr}$ release in the TCLP [25]. Monolith activities involving more ASTM C1308 leaching studies are ongoing that use the centriod clay geopolymer with $42 \mathrm{wt} \%$ dry basis waste loading with BSR and FBSR granular product monoliths. Further monolith formulation activities using the centroid clay recipes at $42 \%$ waste loading, i.e., designated previously as T-22-16-6213 and higher waste loadings of nominally $65 \%$, designated as T-22-16-62-20 will be applied to the radioactive LAW Module B BSR granular product to produce more 1" x 2" cylinder monolith samples for PCT, TCLP and ASTM 1308 testing. Higher waste loadings of the clay recipes have been obtained with added water up to levels used in previous studies of maximum $20 \mathrm{mols}_{2} \mathrm{O}: 1 \mathrm{~mol} \mathrm{Na}_{2} \mathrm{O}$ per reference 50 .

Since previous monolith development focused on the Hanford LAW FBSR granular products and not the WTP SW, future studies should include optimization of the monolith binder formulation targeted at the WTP SW FBSR granular product. Another area of research should be the optimization of monolith waste loading vs. compressive strength, while maintaining adequate durability. Finally, characterizing the effects of REDOX on product durability and how best to control REDOX in the FBSR process should be pursued. 
SRNL-STI-2011-00331

Revision 0

BLANK PAGE

Page 116 of 177 
SRNL-STI-2011-00331

Revision 0

\subsection{References}

1 WTP Contract, Section C, Statement of Work, Contract No. DE-AC27-01RV14136, Modification No. M076, 2007.

2 Jantzen, C.M., "Mineralization of Radioactive Wastes by Fluidized Bed Steam Reforming (FBSR): Comparisons to Vitreous Waste Forms and Pertinent Durability Testing," SRNL, Aiken, SC(2008).

3 Rassat, S.D., Mahoney, L.A., Russell, R.L., Bryan, S.A., Sell, R.L., Cold Dissolved Saltcake Waste Simulant Development, Preparation, and Analysis, Pacific Northwest National Laboratory, Hanford, WA, PNNL-14194 Revision 1, (2003).

4 THOR Treatment Technologies, LLC, Project Number 29387, "Report for Treating Hanford LAW and WTP SW Simulants: Pilot Plant Mineralizing Flowsheet," Document Number RT-21-002, Rev. 1, April 2009.

5 Jantzen, C.M., "Characterization and Performance of Fluidized Bed Steam Reforming (FBSR) Product as a Final Waste Form," Ceramic Transactions, Vol. 155, 319-29 , J. D. Vienna, and D.R. Spearing (Eds) (2004).

6 Jantzen, C.M., "Engineering Study of the Hanford Low Activity Waste (LAW) Steam Reforming Process," Savannah River Technology Center, Aiken, SC, WSRC-TR-2002-00317, (2002).

7 McGrail, B.P., Schaef, H.T., Marting, P.F., Bacon, D.H., Rodriquez, E.A., McReady, D.E., Primak, A.N., Orr, R.D., "Initial Evaluation of Steam-Reformed Low Activity Waste for Direct Land Disposal," Pacific Northwest National Laboratory, Hanford, WA(2003).

8 McGrail, B.P., Pierce, E.M., Schaef, H.T., Rodriquez, E.A., Steele, J.L., Owen, A.T., Wellman, D.M., "Laboratory Testing of Bulk Vitrified and Steam-Reformed Low-Activity Forms to Support a Preliminary Assessment for an Integrated Disposal Facility," PNNL, Hanford, WA, PNNL-14414, (2003).

9 Mann, F.M., Puigh, R.J., Khaleel, R., Finfrock, S., McGrail, B.P., Bacon, D.H., Serne, R.J., "Risk Assessment Supporting the Decision on the Initial Selection of Supplemental ILAW Technologies," PNNL, Hanford, WA, RPP-17675, (2003).

10 Pareizs, J.M., Jantzen, C.M., Lorier, T.H., "Durability Testing of Fluidized Bed Steam Reformer (FBSR) Waste Forms for High Sodium Wastes at Hanford and Idaho," SRNL, Aiken, SC, WSRCTR-2005-00102, (2005).

11 Jantzen, C.M., Pareizs, J.M., Lorier, T.H., Marra, J.C., "Durability Testing of Fluidized Bed Steam Reforming (FBSR) Products," 121-37 in Ceramic Transactions, V. 176, p.121-137, C. C. Herman, S.L. Marra, D.R. Spearing, L. Vance, and J.D. Vienna (Eds) (2006).

12 Jantzen, C.M., Lorier, T.H., Marra, J.C., Pareizs, J.M., "Durability Testing of Fluidized Bed Steam Reforming (FBSR) Waste Forms,” WM'06, Tucson, AZ, (2006)

13 Marshall, D.W., Soelberg, N.R., Shaber, K.M., "THOR ${ }^{\mathrm{sm}}$ Bench-Scale Steam Reforming Demonstration," Idaho National Laboratory, Idaho Falls, ID, INEEL/EXT.03-00437, (2003). 
14 Jantzen, C.M., "Fluidized Bed Steam Reformer (FBSR) Product: Monolith Formation and Characterization," Savannah River National Laboratory, Aiken, SC, WSRC-STI-2006-00033, (2006).

15 Jantzen, C.M., "Fluidized Bed Steam Reformer (FBSR) Monolith Formation," WM'07, Tucson, AZ, (2007).

16 Olson, A.L., Soelberg, N.R., Marshall, D.W., Anderson, G.L., "Fluidized Bed Steam Reforming of Hanford LAW Using THOR ${ }^{\text {sm }}$ Mineralizing Technology," INL, Idaho Falls, ID, INEEL/EXT-0402492, (2004).

17 Lorier, T.H., Pareizs, J.M., Jantzen, C.M., "Single Pass Flow through (SPFT) Testing of Fluidized Bed Steam Reforming (FBSR) Waste Forms," SRNL, Aiken, SC, WSRC-TR-2005-00124, (2005).

18 Jantzen, C.M., Lorier, T.H., Pareizs, J.M., Marra, J.C., "Fluidized Bed Steam Reformed (FBSR) Mineral Waste Forms: Characterization and Durability Testing," pp. 379-86 in Scientific Basis for Nuclear Waste Management XXX. Edited by D. S. Dunn, C. Poinssot, B. Begg. (2007).

19 Olson, A.L., Soelberg, N.R., Marshall, D.W., Anderson, G.L., "Fluidized Bed Steam Reforming of INEEL SBW Using THOR ${ }^{\mathrm{sm}}$ Mineralizing Technology," INL, Idaho Falls, ID, INEEL/EXT-0402564, (2004).

20 Crawford, C.L., Jantzen, C.M., "Durability Testing of Fluidized Bed Steam Reformer (FBSR) Waste Forms for Sodium Bearing Waste (SBW) at INL, SRNL, Aiken, SC, WSRC-STI-2007-00319, (2007).

21 Jantzen, C.M., Crawford, C.L., "Mineralization of Radioactive Wastes by Fluidized Bed Steam Reforming (FBSR): Radionuclide Incorporation, Monolith Formation, and Durability Testing," WM'10, Phoenix, AZ, (2010).

22 Crawford, C.L and Jantzen, C.M., "Evaluation of THOR ${ }^{\circledR}$ Mineralized Waste Forms (Granular and Monolith) for the DOE Advanced Remediation Technologies (ART) Phase 2 Project", SRNL-STI2009-00505, Rev.0 (December 2011).

23 DOE EM-31 Technology Development \& Deployment (TDD) Program Task Plan, "Fluidized Bed Steam Reformer Low-Level Waste Form Qualification,” WP-5.2.1-2010-001, Rev. 0, Sept. 30, 2010.

24 Jantzen, C.M., Bannochie, C.J., Burket, P.R., Cozzi, A.D.,Crawford, C.L., W.E., Missimer, D.M., and Nash, C.A., "Radioactive Demonstration of Mineralized Waste Forms Made from Hanford Low Activity Waste (Tank Farm Blend) by Fluidized Bed Steam Reformation (FBSR)," SRNL-STI-201100383 (in draft).

25 Jantzen, C.M., Bannochie, C.J., Burket, P.R., Cozzi, A.D.,Crawford, C.L., Daniel, W.E., Missimer, D.M., and Nash, C.A., "Radioactive Demonstration of Mineralized Waste Forms Made from Hanford Low Activity Waste (Tank SX-105, Tank AN-103 and Tank AZ-101/AZ-102) by Fluidized Bed Steam Reformation (FBSR)," SRNL-STI-2011-00384 (in draft).

26 Lutze, W. and Ewing, R.C., "Radioactive Waste Forms for the Future," Elsevier Science Publishers, Amsterdam, The Netherlands, 778pp (1988). 
27 Hatch, L.P., “Ultimate Disposal of Radioactive Wastes,” Am. Scientist, 41, 410-421 (1953).

28 Roy, R., "Hydroxylated Ceramic Waste Forms and the Absurdity of Leach Tests," Proc. Int. Sem. On Chem. and Process Eng. for High-Level Liquid Waste Solidification, Vol. 2, Julich, JUL-Conf-42, eds. R. Odoj and E. Merz, 576-602 (1981).

29 Mason, J.B., Oliver, T. W., Carson, M. P., Hill, G. M., "Studsvik Processing Facility Pyrolysis/Steam Reforming Technology for Volume and Weight Reduction and Stabilization of LLRW and Mixed Wastes," Waste Management 99 (1999).

30 Mason, J. B., McKibben, J., Ryan, K., Schmoker, D., "Steam Reforming Technology for Denitration and Immobilization of DOE Tank Wastes, Waste Management 03 (2003).

31 Jantzen, C.M., Williams, M.R., Bibler, N.E., Crawford, C.L. and Jurgensen, A.R., "Fluidized Bed Steam Reformed (FBSR) Mineral Waste Forms: Application to Cs-137/Sr-90 Wastes for the Global Nuclear Energy Partnership (GNEP),”WSRC-MS-2008-00013 (2008).

32 Soelberg, N.R., Marshall, D.M., Bates, S.O., Siemer, D.D., "SRS Tank 48H Steam Reforming Proofof-Concept Test Report," Idaho National Laboratory, Idaho Falls, ID, INEEL/EXT-03-01118, Rev 1, (2004).

33 Jantzen, C.M., "Disposition of Tank 48H Organics by Fluidized Bed Steam Reforming (FBSR)," WSRC-TR-2003-00352, Savannah River Natl. Laboratory, (2003).

34 Klingenberg, R. and Felsche, J., "Interstitial Cristobalite-type Compounds $\left(\mathrm{Na}_{2} \mathrm{O}\right) 0.33 \mathrm{Na}\left[\mathrm{AlSiO}_{4}\right]$, " J. Solid State Chemistry, 61, 40-46 (1986).

35 Buhl, J.Ch, Englehardt, G. and Felsche, J., "Synthesis, X-ray Diffraction, and MAS n.m.r. Characteristics of Tetrahydroxoborate Sodalite," Zeolites, 9, 40-44 (1989).

36 Fleet, M.E., "Structures of Sodium Alumino-Germanate Sodalites,”Acta Cryst.C45, 843-847 (1989).

37 Sinkler, W., O'Holleran, T.P., Frank, S.M., Richmann, M.K. and Johnson, S.G., "Characterization of a Glass-Bonded Ceramic Waste Form Loaded with U and Pu," Sci.Basis Nucl. Waste Mgt., XXIII, Mat. Res. Soc.: Pittsburgh, PA, 423-429 (2000).

38 Moschetti, T.L., Sinkler, W., DiSanto, T. Novy, M.H., Warren, A.R., Cummings, D., Johnson, S.G., Goff, K.M., Bateman, K.J., Frank, S.M., "Characterization of a Ceramic Waste Form Encapsulating Radioactive Electrorefiner Salt,” ibid, 577-582 (2000).

39 Deer, W.A. Howie, R.A., Wise, W.S. and Zussman, J., "Rock-Forming Minerals, Vol. 4B, Framework Silicates: Silica Minerals, Feldspathoids and the Zeolites," The Geological Society, London, UK, 982pp (2004).

40 Deer, W.A., Howie, R.A., and Zussman, J., “Rock-Forming Minerals, V. 4,” John Wiley \& Sons, Inc., NY, 435pp (1963). 
41 Brookins, D.G., Geochemical Aspects of Radioactive Waste Disposal; Springer-Verlag: NY, 347pp (1984).

42 Dana, E.S.“A Textbook of Mineralogy,” John Wiley \& Sons, Inc., New York, 851pp (1932).

43 Mattigod, S.V., McGrail,B.P., McCready,D.E., Wang, L, Parker, K.E. and Young, J.S. "Synthesis and Structure of Perrhenate Sodalite," J. Microporous \& Mesopourous Materials, 91 (1-3), 139-144 (2006).

44 Barrer,R.M. "Hydrothermal Chemistry of Zeolites," Academic Press, New York, 360pp (1982): see references by St. J. Thugutt, Z. Anorg. Chem, 2, 65 (1892) and E. Flint, W. Clarke, E.S. Newman, L. Shartsis, D. Bishop and L.S. Wells, J. Res. Natl. Bur. Stds, 36, 63 (1945).

45 Tobbens, D.M.and Buhl, J.C. "Superstructure of Sodiumborate Sodalite," Berline Neutron Scattering Center (BENSC) Experimental Report E9, Helmholtz Zentrum fur Materialiene und Energie (formally the Hahn-Meitner Institute), Berlin, Germany (2000).

46 Burket, P.R., Daniel, W.E., Nash, C.A., Jantzen, C.M., and Williams, M.R., "Bench-Scale Steam Reforming of Actual Tank 48 Waste" US DOE Report SRNL-STI-2008-00105 (September 2008).

47 Burket, P.R., Daniel, W.E., Jantzen, C.M., Nash, C.A., Crawford, C.L., Williams, M.R., and Barnes, A.B., "Steam Reforming Technology Demonstration for the Destruction of Organics on Actual DOE Savannah River Site Tank 48H Waste," Paper \#9138 WM09.

48 SRNL E\&CPT Research Programs Section Procedure Manual L29, 'Determining $\mathrm{Fe}^{2+} / \mathrm{Fe}^{3+}$ and $\mathrm{Fe}^{2+} / \mathrm{Fe}$ (total) Using UV VIS Spectrometer', ITS-0042, Rev. 1, 6/12/09.

49 Jantzen, C. M. et al., Fluidized Bed Steam Reforming Waste Form Performance Testing to Support Hanford Supplemental Low Activity Waste Immobilization Technology Selection, SRNL-STI-201100387, Rev. 0, August 2011.

50 Jantzen, C. M., Crawford, C. L. and Cozzi, A. D., "Fluidized Bed Steam Reformer (FBSR) Monolith Recovery Report,” SRNL Memo SRNL L3100-2011-00100, June 6, 2011.

51 ASTM C39/39M-10 Standard Test Method for Compressive Strength of Cylindrical Concrete Specimens.

52 ASTM C1231/C1231M - 10a Standard Practice for Use of Unbonded Caps in Determination of Compressive Strength of Hardened Concrete Cylinders.

53 ASTM C 1285-08, 'Standard Test Methods for Determining Chemcial Durability of Nuclear, Hazardous, and Mixed Waste Glasses and Multiphase Glass Ceramics: The Product Consistency Test (PCT), ASTM International, West Conshohocken, PA.

54 WAPS-Waste Acceptance Product Specifications for Vitrified High Level Waste Forms, U. S. Department of Energy, Office of Environmental Restoration and Waste Management, USDOE Document EM-WAPS, Washington, DC (February, 2003). 
55 Ebert, W. L. and S. F. Wolf, "An Interlaboratory Study of a Standard Glass for Acceptance Testing of Low-activity Waste Glass,” J. of Nuc. Materials, 282, pp. 112-124, 2000.

56 Brantley, S. L. and Mellot, N. P., "Surface area and porosity of primary silicate minerals", American Mineralogist, 85, 2000, 1767 - 1783.

57 Crank J. 1986. The Mathematics of Diffusion. Oxford University Press, London.

58 Land Disposal Restrictions. Code of Federal Regulations, Part 268, Title 40, 2004.

59 Office of Solid Waste, US EPA. TCLP Method 1311, Test Methods for Evaluating Solid Waste; Physical/Chemical Methods, Third Edition; EPA 530/SW-846; National Technical Information Service: Washington, DC, 1986.

60 Qafoku, N.P., Valenta, M. M., Strachan, D. M., Westsik, J. H. Jr. and Pires, R. P., "Secondary Waste Form Down-Selection Data Package-Fluidized Bed Steam Reforming Waste Form", PNNLDRAFT, May 2011.

61 "Evaluation of Radionuclide THOR $^{\circledR}$ Mineralized Waste Forms (Granular and Monolith) for the DOE Advanced Remediation Technologies (ART) Phase 2 Project", SRNL TT\&QAP, SRNL-STI-2009$00179,8 / 27 / 09$. 
SRNL-STI-2011-00331

Revision 0

BLANK PAGE

Page 122 of 177 
Appendix A. PCT Data for ARM and LRM Glasses

\begin{tabular}{|c|c|c|c|c|c|c|c|c|c|}
\hline & & Al & $\mathbf{N a}$ & $\mathbf{S i}$ & pH & Al / Al ref & $\mathrm{Na} / \mathrm{Na}$ ref & Si / Si ref & $\mathrm{pH} / \mathrm{pH}$ ref \\
\hline & & $(\mathrm{mg} / \mathrm{L})$ & $(\mathrm{mg} / \mathrm{L})$ & $(\mathrm{mg} / \mathrm{L})$ & & & & & \\
\hline Simulant WTP SW & ARM-1 & 4.4 & 32.6 & 55.1 & 10.4 & & & & \\
\hline \multirow[t]{11}{*}{ Granular Product } & ARM-2 & 4.2 & 32.8 & 55.9 & 10.5 & & & & \\
\hline & ARM-3 & 4.5 & 34.5 & 57.4 & 10.4 & & & & \\
\hline & Avg. & 4.4 & 33.3 & 56.1 & 10.4 & & & & \\
\hline & St.Dev. & 0.2 & 1.1 & 1.2 & 0.03 & & & & \\
\hline & Ref. Values & $4.85(0.5)$ & $36.22(2.45)$ & $61.23(4.07)$ & $10.17(0.29)$ & 0.90 & 0.92 & 0.92 & 1.03 \\
\hline & LRM-1 & 13.9 & 142.6 & 70.8 & 11.1 & & & & \\
\hline & LRM-2 & 14.0 & 141.8 & 71.5 & 11.2 & & & & \\
\hline & LRM-3 & 14.1 & 143.9 & 70.7 & 11.1 & & & & \\
\hline & Avg. & 14.0 & 142.8 & 71.0 & 11.1 & & & & \\
\hline & St.Dev. & 0.1 & 1.0 & 0.4 & 0.01 & & & & \\
\hline & Ref. Values & $14.3(2.61)$ & $160(11.5)$ & $82(3.53)$ & $10.92(0.092)$ & 0.98 & 0.89 & 0.87 & 1.02 \\
\hline Simulant WTP SW & ARM-X7 & 5.0 & 33.2 & 61.0 & 10.1 & & & & \\
\hline \multirow[t]{11}{*}{ Monolith } & ARM-X8 & 5.0 & 34.4 & 62.4 & 10.1 & & & & \\
\hline & ARM-X16 & 5.1 & 34.6 & 63.2 & 10.1 & & & & \\
\hline & Avg. & 5.0 & 34.1 & 62.2 & 10.1 & & & & \\
\hline & St.Dev. & 0.1 & 0.8 & 1.1 & 0.01 & & & & \\
\hline & Ref. Values & $4.85(0.5)$ & $36.22(2.45)$ & $61.23(4.07)$ & $10.17(0.29)$ & 1.04 & 0.94 & 1.02 & 0.99 \\
\hline & LRM-X28 & 13.2 & 163.4 & 87.8 & 10.8 & & & & \\
\hline & LRM-X31 & 13.2 & 153.2 & 87.8 & 10.8 & & & & \\
\hline & LRM-X33 & 13.6 & 163.2 & 90.4 & 10.8 & & & & \\
\hline & Avg. & 13.3 & 159.9 & 88.7 & 10.8 & & & & \\
\hline & St.Dev. & 0.2 & 5.8 & 1.5 & 0.0 & & & & \\
\hline & Ref. Values & $14.3(2.61)$ & $160(11.5)$ & $82(3.53)$ & $10.92(0.092)$ & 0.93 & 1.00 & 1.08 & 0.99 \\
\hline Radioactive WTP SW & ARM 1 & 4.9 & 39.9 & 65.1 & 9.5 & & & & \\
\hline Granular Product \& & ARM 2 & 5.1 & 39.4 & 64.6 & 9.6 & & & & \\
\hline \multirow[t]{10}{*}{ Monolith } & ARM 3 & 4.8 & 34.6 & 57.0 & 9.5 & & & & \\
\hline & Avg. & 4.9 & 37.9 & 62.2 & 9.5 & & & & \\
\hline & St.Dev. & 0.2 & 2.9 & 4.5 & 0.02 & & & & \\
\hline & Ref. Values & $4.85(0.5)$ & $36.22(2.45)$ & $61.23(4.07)$ & $10.17(0.29)$ & 1.02 & 1.05 & 1.02 & 0.94 \\
\hline & LRM 1 & 13.4 & 141.2 & 75.3 & 10.2 & & & & \\
\hline & LRM 2 & 13.8 & 148.3 & 77.3 & 10.2 & & & & \\
\hline & LRM 3 & 13.4 & 141.7 & 75.3 & 10.2 & & & & \\
\hline & Avg. & 13.5 & 143.7 & 75.9 & 10.2 & & & & \\
\hline & St.Dev. & 0.2 & 4.0 & 1.2 & 0.01 & & & & \\
\hline & Ref. Values & $14.3(2.61)$ & $160(11.5)$ & $82(3.53)$ & $10.92(0.092)$ & 0.95 & 0.90 & 0.93 & 0.93 \\
\hline
\end{tabular}


SRNL-STI-2011-00331

Revision 0

\section{Appendix B. BSR Process Operation Conditions \& Trends for Original Simulant Runs 2009}

Table B 1. BSR Process Operation Conditions \& Results for Original Simulant Runs 2009

\begin{tabular}{|c|c|c|c|c|c|c|}
\hline Run Date & $8 / 26 / 09$ & $9 / 02 / 09$ & $9 / 08 / 09$ & $9 / 10 / 09$ & $9 / 15 / 09$ & $9 / 17 / 09$ \\
\hline $\begin{array}{l}\text { Slurry Feed } \\
\text { Rate }\end{array}$ & $1 \mathrm{~mL} / \mathrm{min}$ & $1 \mathrm{~mL} / \mathrm{min}$ & $1 \mathrm{~mL} / \mathrm{min}$ & $1 \mathrm{~mL} / \mathrm{min}$ & $1 \mathrm{~mL} / \mathrm{min}$ & $1 \mathrm{~mL} / \mathrm{min}$ \\
\hline $\begin{array}{l}\text { DMR Bed } \\
\text { Temp }\end{array}$ & $720{ }^{\circ} \mathrm{C}$ & $720{ }^{\circ} \mathrm{C}$ & $720{ }^{\circ} \mathrm{C}$ & $685-715^{\circ} \mathrm{C}$ & $685-715^{\circ} \mathrm{C}$ & $685-715^{\circ} \mathrm{C}$ \\
\hline $\begin{array}{l}\text { Superheated } \\
\text { Steam }\end{array}$ & $0.60 \mathrm{~g} / \mathrm{min}$ & $\begin{array}{c}0.60 \\
\mathrm{~g} / \mathrm{min}\end{array}$ & $\begin{array}{c}0.60 \\
\mathrm{~g} / \mathrm{min}\end{array}$ & $\begin{array}{c}0.60 \\
\mathrm{~g} / \mathrm{min}\end{array}$ & $\begin{array}{c}0.60 \\
\mathrm{~g} / \mathrm{min}\end{array}$ & $\begin{array}{c}0.60 \\
\mathrm{~g} / \mathrm{min}\end{array}$ \\
\hline $\begin{array}{l}\text { DMR Control } \\
\text { Pressure } \\
\end{array}$ & -3 inwc & -3 inwc & -3 inwc & -3 inwc & -3 inwc & -3 inwc \\
\hline Carbon & $\begin{array}{c}20 \mathrm{~g} / \\
100 \mathrm{~mL} \\
\text { feed/clay } \\
\text { mixture } \\
(0.2 \mathrm{~g} \\
\mathrm{C} / \mathrm{min})\end{array}$ & $\begin{array}{c}20 \mathrm{~g} / \\
100 \mathrm{~mL} \\
\text { feed/clay } \\
\text { mixture } \\
(0.2 \mathrm{~g} \\
\mathrm{C} / \mathrm{min})\end{array}$ & $\begin{array}{c}20 \mathrm{~g} / \\
100 \mathrm{~mL} \\
\text { feed/clay } \\
\text { mixture } \\
(0.2 \mathrm{~g} \\
\mathrm{C} / \mathrm{min}) \\
\end{array}$ & $\begin{array}{c}20 \mathrm{~g} / \\
100 \mathrm{~mL} \\
\text { feed/clay } \\
\text { mixture } \\
(0.2 \mathrm{~g} \\
\mathrm{C} / \mathrm{min}) \\
\end{array}$ & $\begin{array}{c}16 \mathrm{~g} / \\
100 \mathrm{~mL} \\
\text { feed/clay } \\
\text { mixture } \\
(0.16 \mathrm{~g} \\
\mathrm{C} / \mathrm{min})\end{array}$ & $\begin{array}{c}16 \mathrm{~g} / \\
100 \mathrm{~mL} \\
\text { feed/clay } \\
\text { mixture } \\
(0.16 \mathrm{~g} \\
\mathrm{C} / \mathrm{min})\end{array}$ \\
\hline $\begin{array}{l}\text { Total } \\
\text { Controlled } \\
\text { Gas Flow }\end{array}$ & $700 \mathrm{sccm}$ & $700 \mathrm{sccm}$ & $700 \mathrm{sccm}$ & $700 \mathrm{sccm}$ & $700 \mathrm{sccm}$ & $700 \mathrm{sccm}$ \\
\hline $\begin{array}{l}\mathrm{H}_{2} \\
\text { Concentration } \\
\text { Control }\end{array}$ & $1.5-3.0 \%$ & $1.5-3.0 \%$ & $1.5-3.0 \%$ & $1.5-3.0 \%$ & $1.5-3.0 \%$ & $1.5-3.0 \%$ \\
\hline $\begin{array}{l}\text { Post Feed Run } \\
\text { Time (hrs) }\end{array}$ & 0 & 0.5 & 1.5 & 2 & 5 & 3 \\
\hline $\begin{array}{l}\text { Product } \\
\text { REDOX } \\
\text { Target }(0.72- \\
0.92)\end{array}$ & $0.91 / 0.97$ & $0.98 / 0.95$ & $0.98 / 0.98$ & $0.90 / 0.89$ & $0.96 / 0.95$ & $0.87 / 0.87$ \\
\hline $\begin{array}{l}\text { Product LOI } \\
\text { Target (10 - } \\
12 \%)\end{array}$ & 16.4 & 17.1 & 15.5 & 10.7 & 10.3 & 7.9 \\
\hline $\begin{array}{l}\text { Product } \\
\text { Quantity (g) } \\
\text { before } \\
\text { sampling } \\
\end{array}$ & 26.6 & 35.3 & 32 & 32 & 31.9 & 30.3 \\
\hline $\begin{array}{l}\text { Feed Quantity } \\
\text { (g) }\end{array}$ & $\begin{array}{c}\text { Not } \\
\text { recorded }\end{array}$ & Not recorded & Not recorded & 118 & 120 & 121 \\
\hline $\begin{array}{l}\text { Off Gas } \\
\text { Conditioning }\end{array}$ & $\begin{array}{l}\text { Bubbler / } \\
\text { Dry Ice }\end{array}$ & $\begin{array}{c}\text { Bubbler / Dry } \\
\text { Ice }\end{array}$ & $\begin{array}{l}\text { Bubbler / Dry } \\
\text { Ice and } 50 \text { um } \\
\text { filter }\end{array}$ & $\begin{array}{l}\text { Bubbler / Dry } \\
\text { Ice and } 25 \text { um } \\
\text { / } 2 \text { um filter } \\
\text { train }\end{array}$ & $\begin{array}{l}\text { Bubbler and } \\
25 \text { um / } 2 \text { um } \\
\text { filter train }\end{array}$ & $\begin{array}{l}\text { Bubbler and } \\
25 \text { um / } 2 \text { um } \\
\text { filter train }\end{array}$ \\
\hline $\begin{array}{l}\text { DMR Temp } \\
\text { Control } \\
\end{array}$ & Bed Temp & Bed Temp & $\begin{array}{c}\text { Bed Surface } \\
\text { Temp }\end{array}$ & $\begin{array}{l}\text { Reaction } \\
\text { Zone Top } \\
\end{array}$ & $\begin{array}{l}\text { Reaction } \\
\text { Zone Top } \\
\end{array}$ & $\begin{array}{l}\text { Reaction } \\
\text { Zone Top } \\
\end{array}$ \\
\hline
\end{tabular}




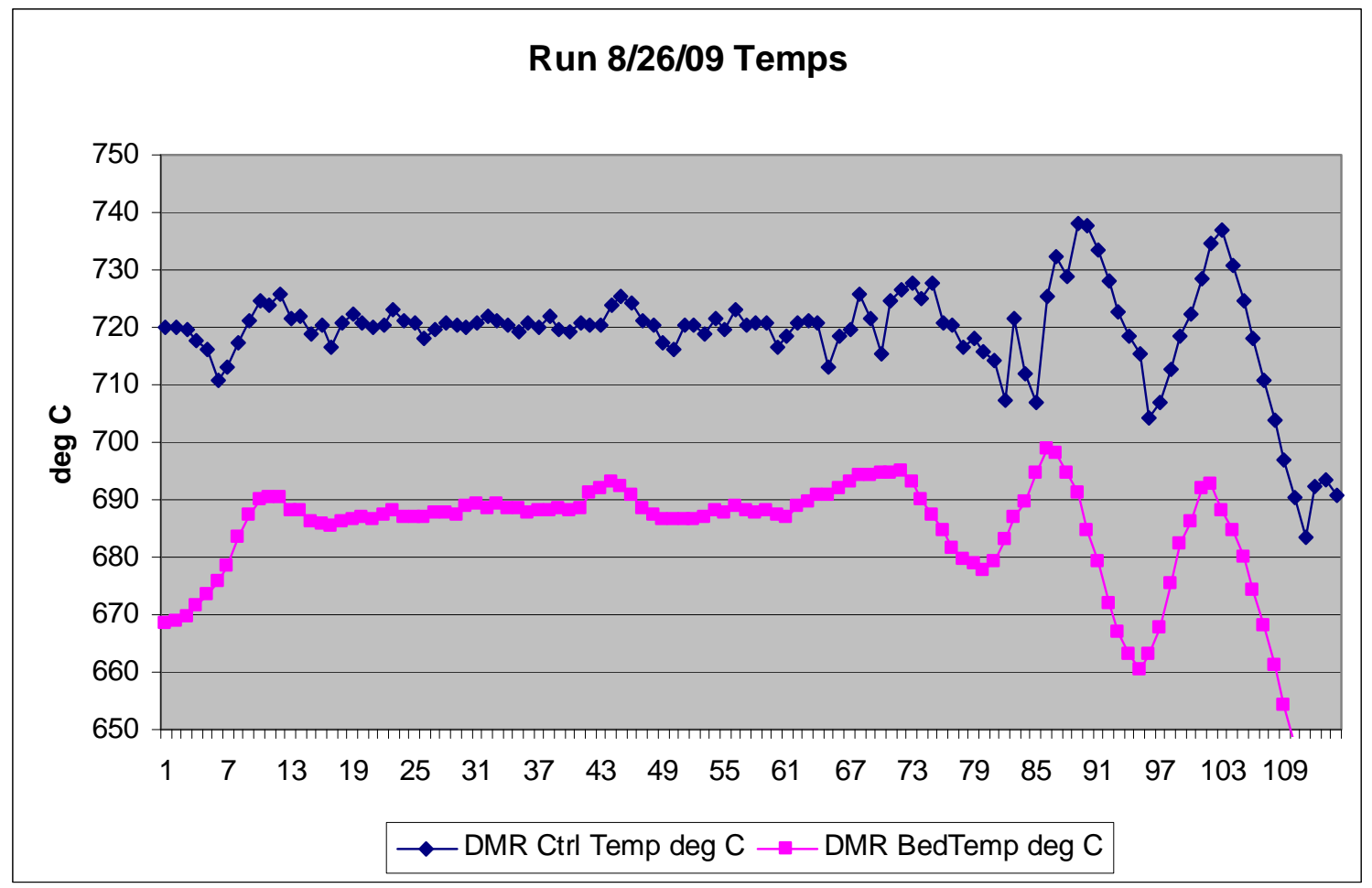

Figure B 1. Run 8/26/09 Temperatures in DMR

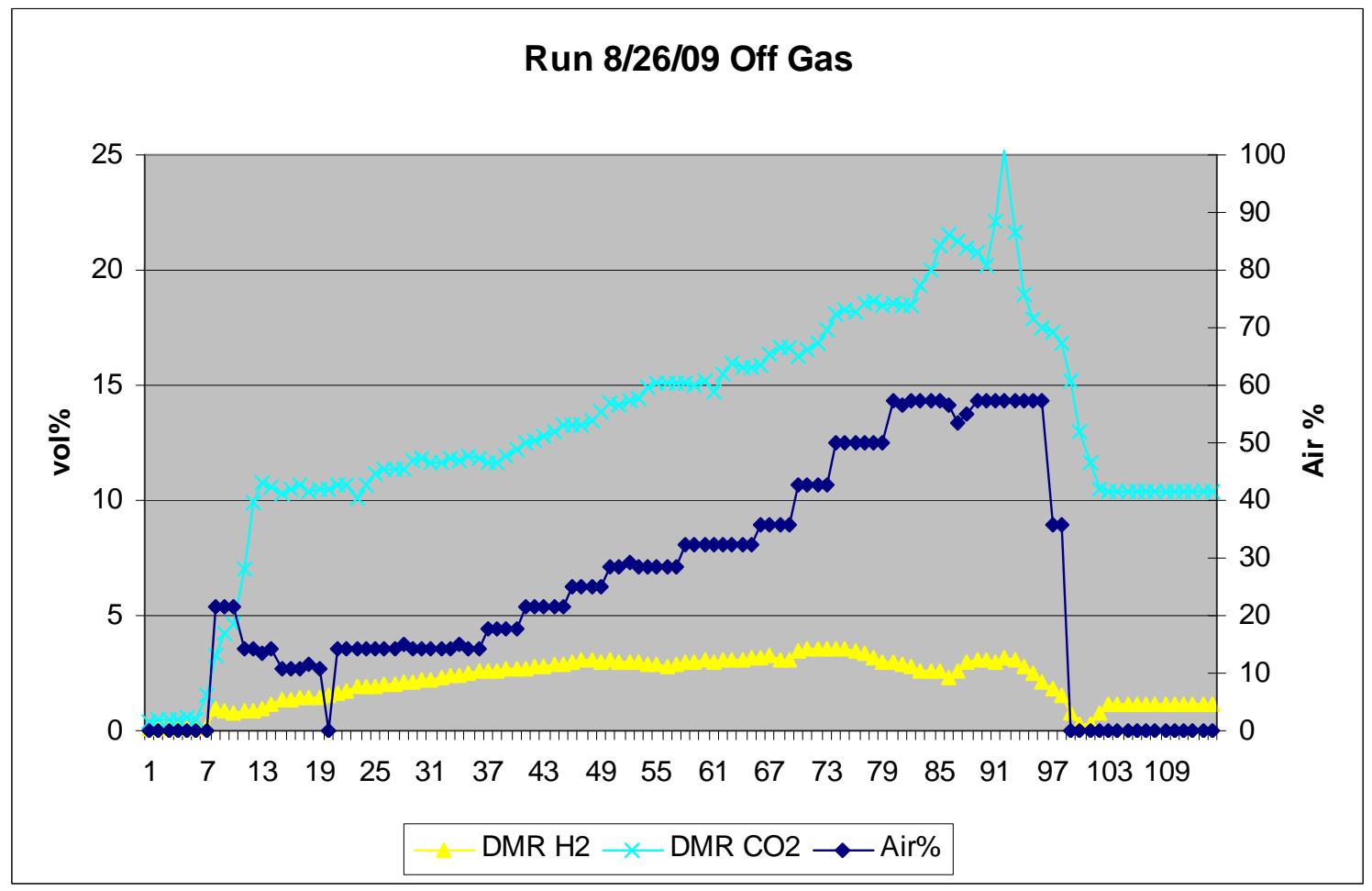

Figure B 2. Run 8/26/09 Off Gas Concentrations and Air\% Fed 


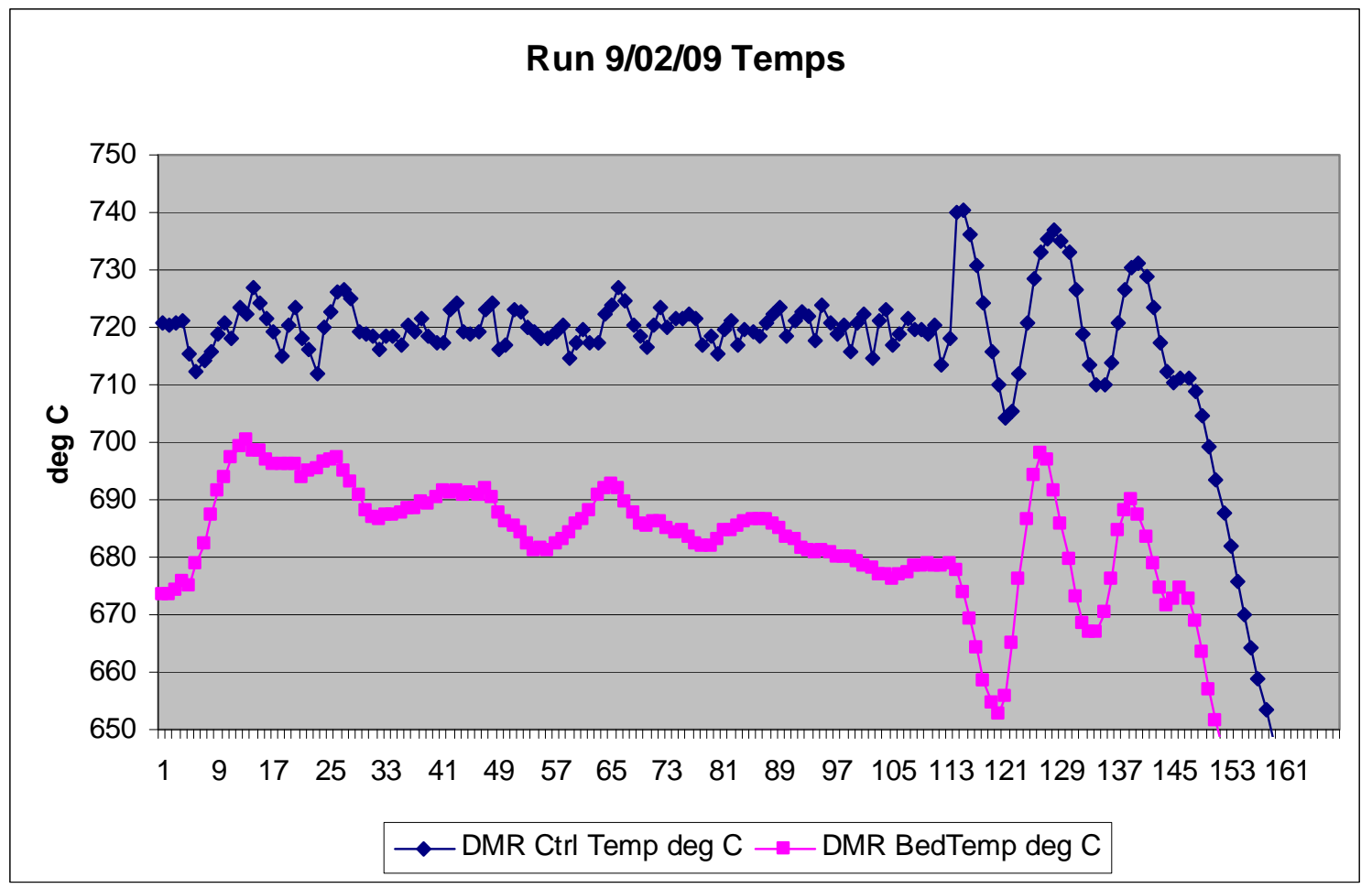

Figure B 3. Run 9/02/09 Temperatures in DMR

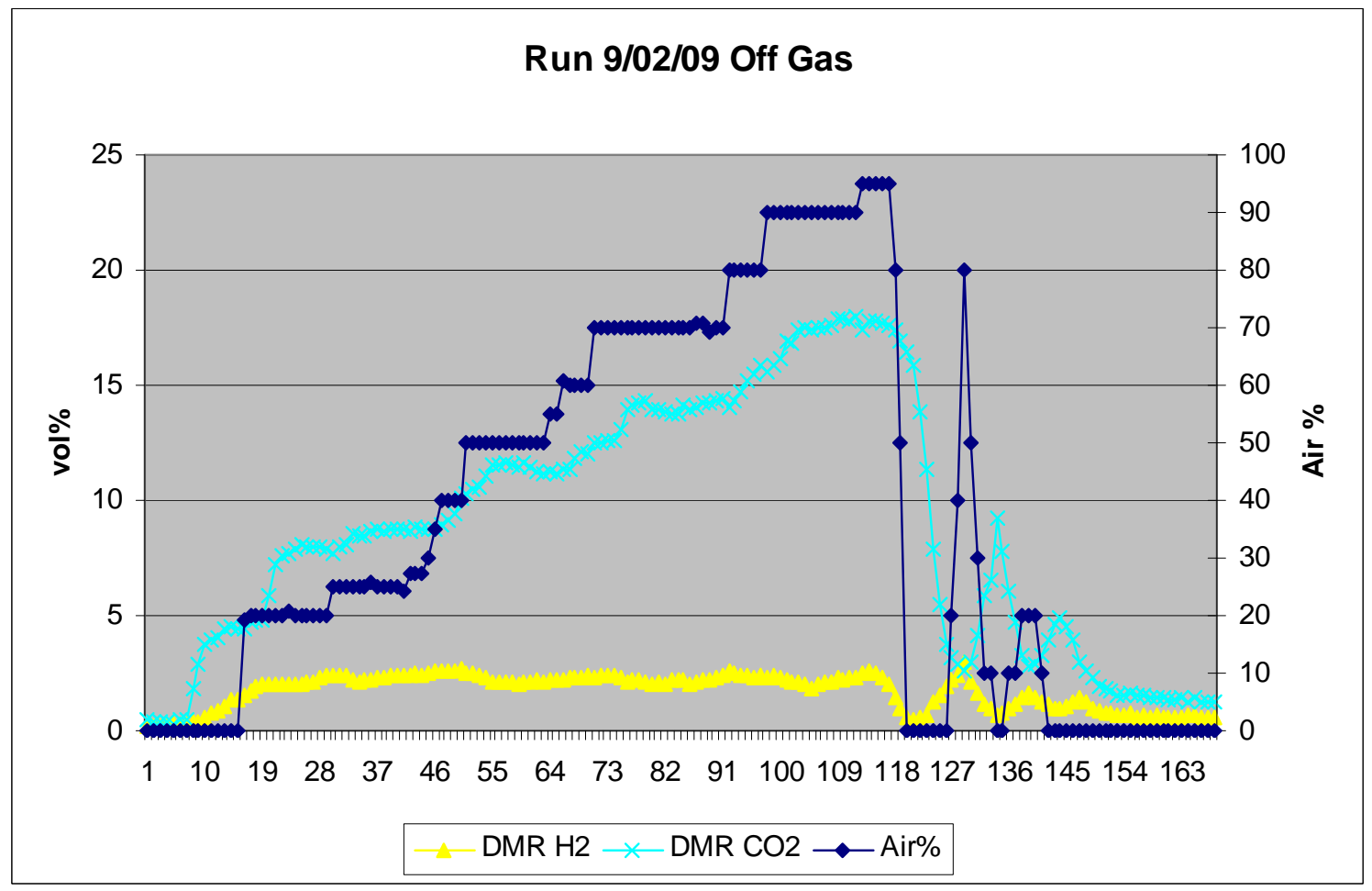

Figure B 4. Run 9/02/09 Off Gas Concentrations and Air\% Fed 


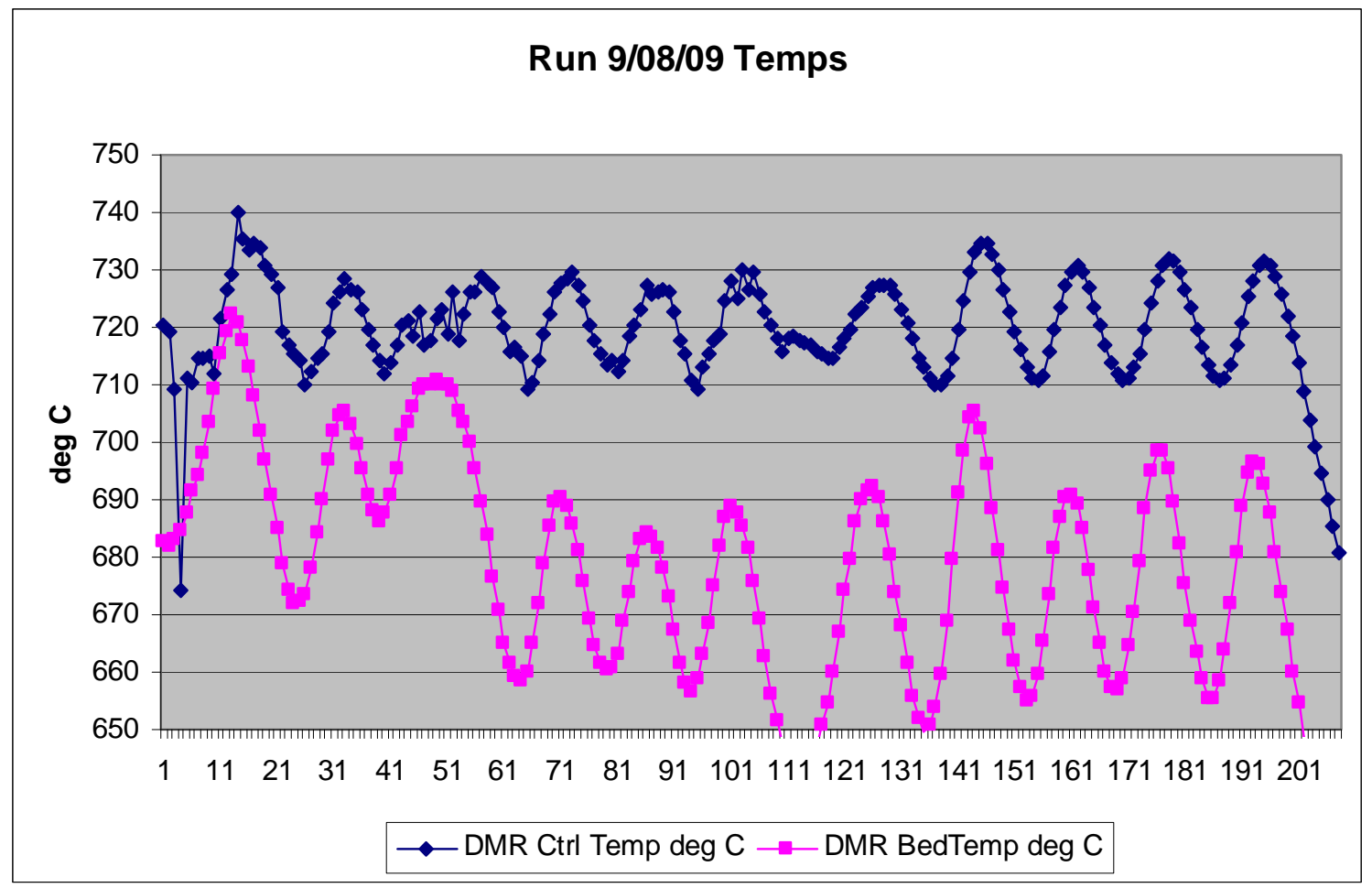

Figure B 5. Run 9/08/09 Temperatures in DMR

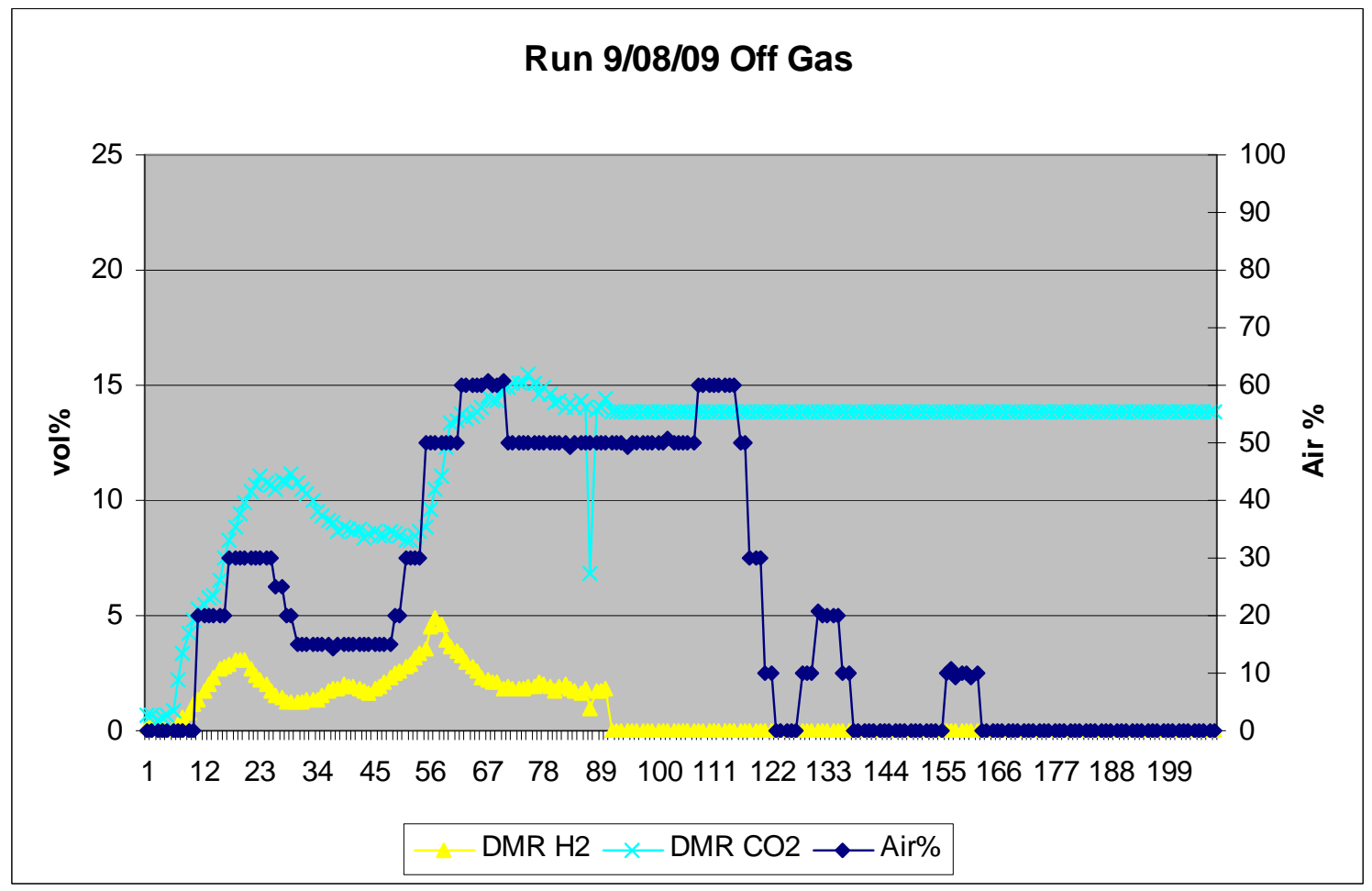

Figure B 6. Run 9/08/09 Off Gas Concentrations and Air\% Fed 


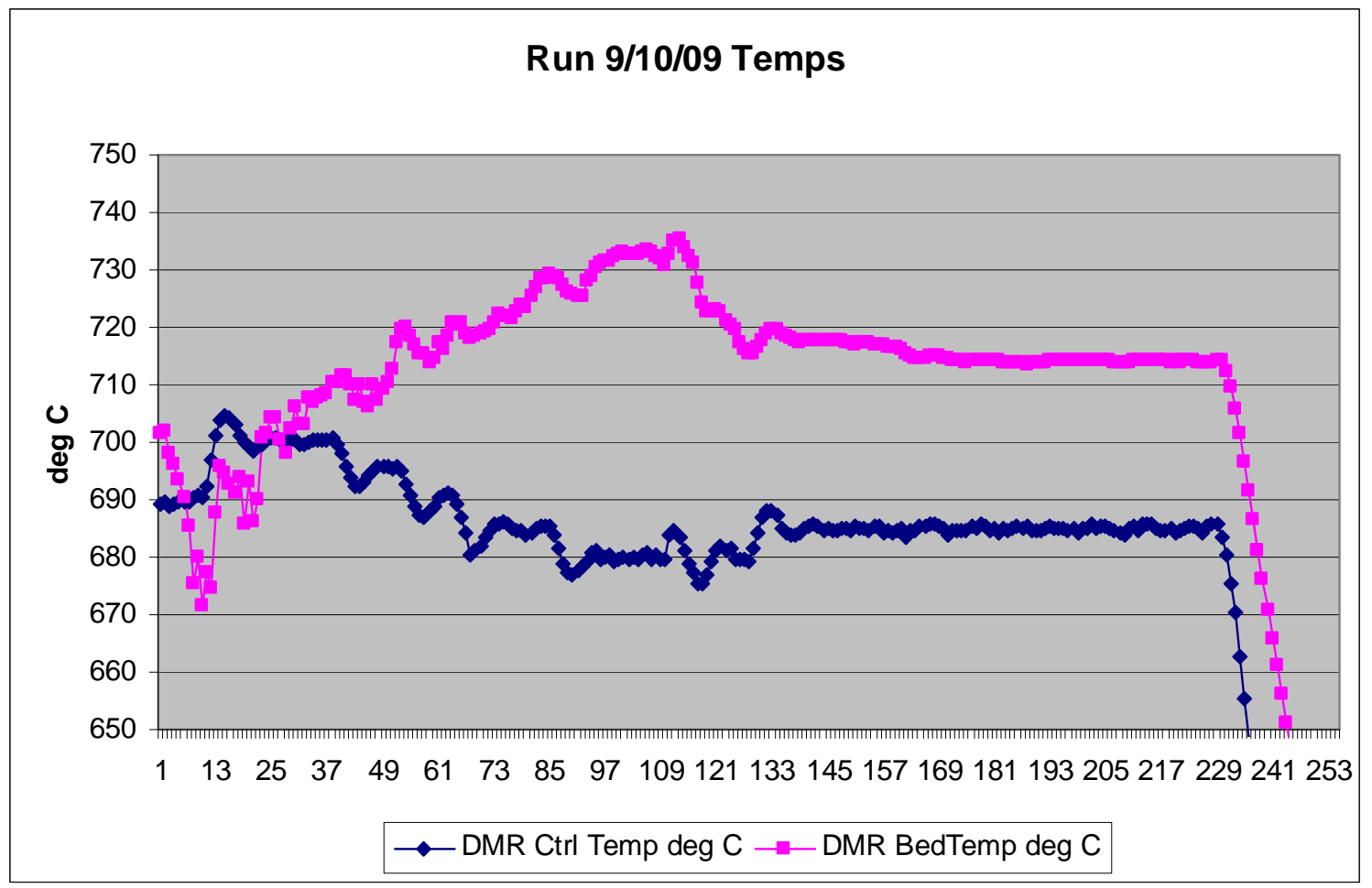

Figure B 7. Run 9/10/09 Temperatures in DMR

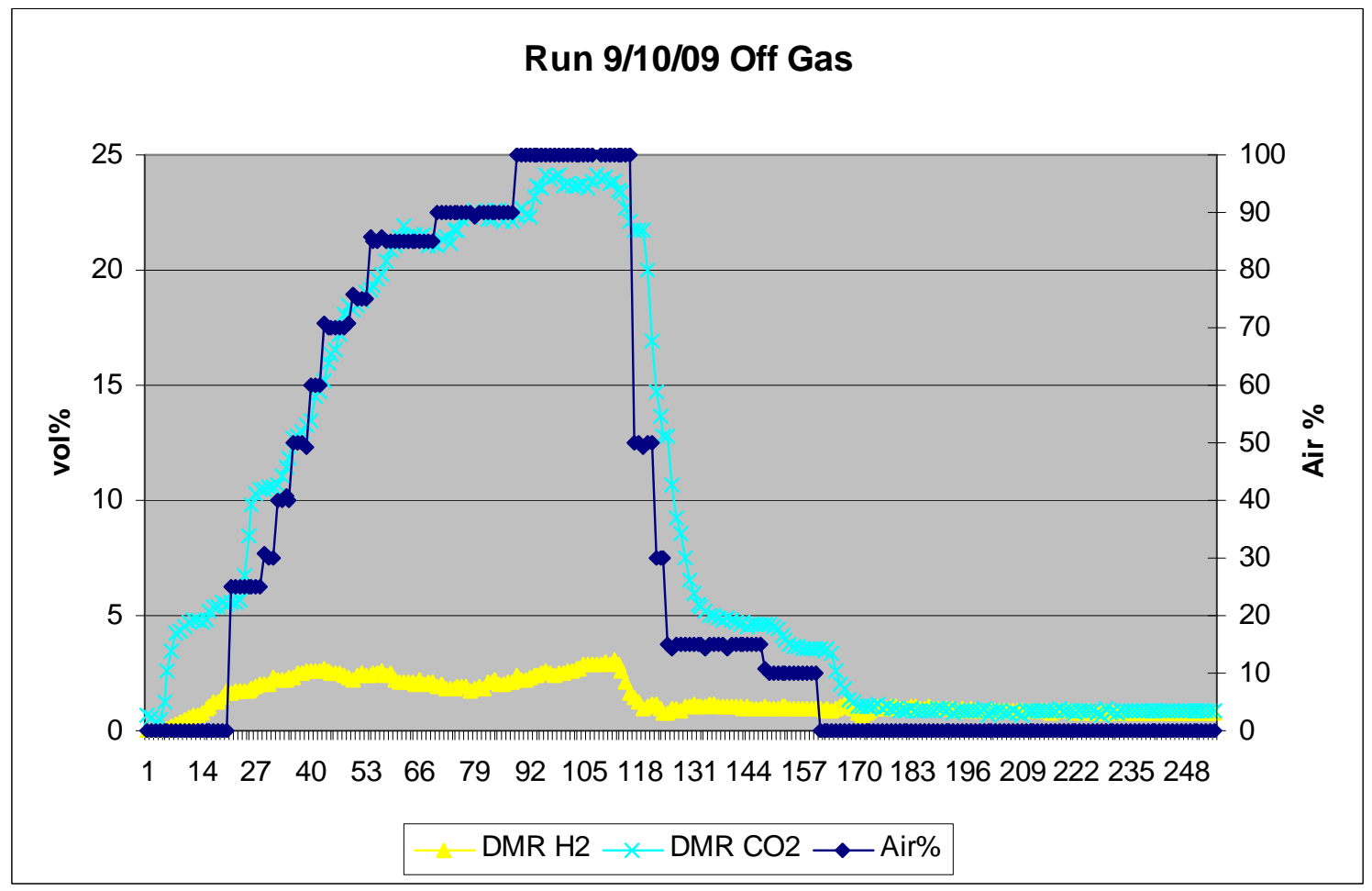

Figure B 8. Run 9/10/09 Off Gas Concentrations and Air\% Fed 


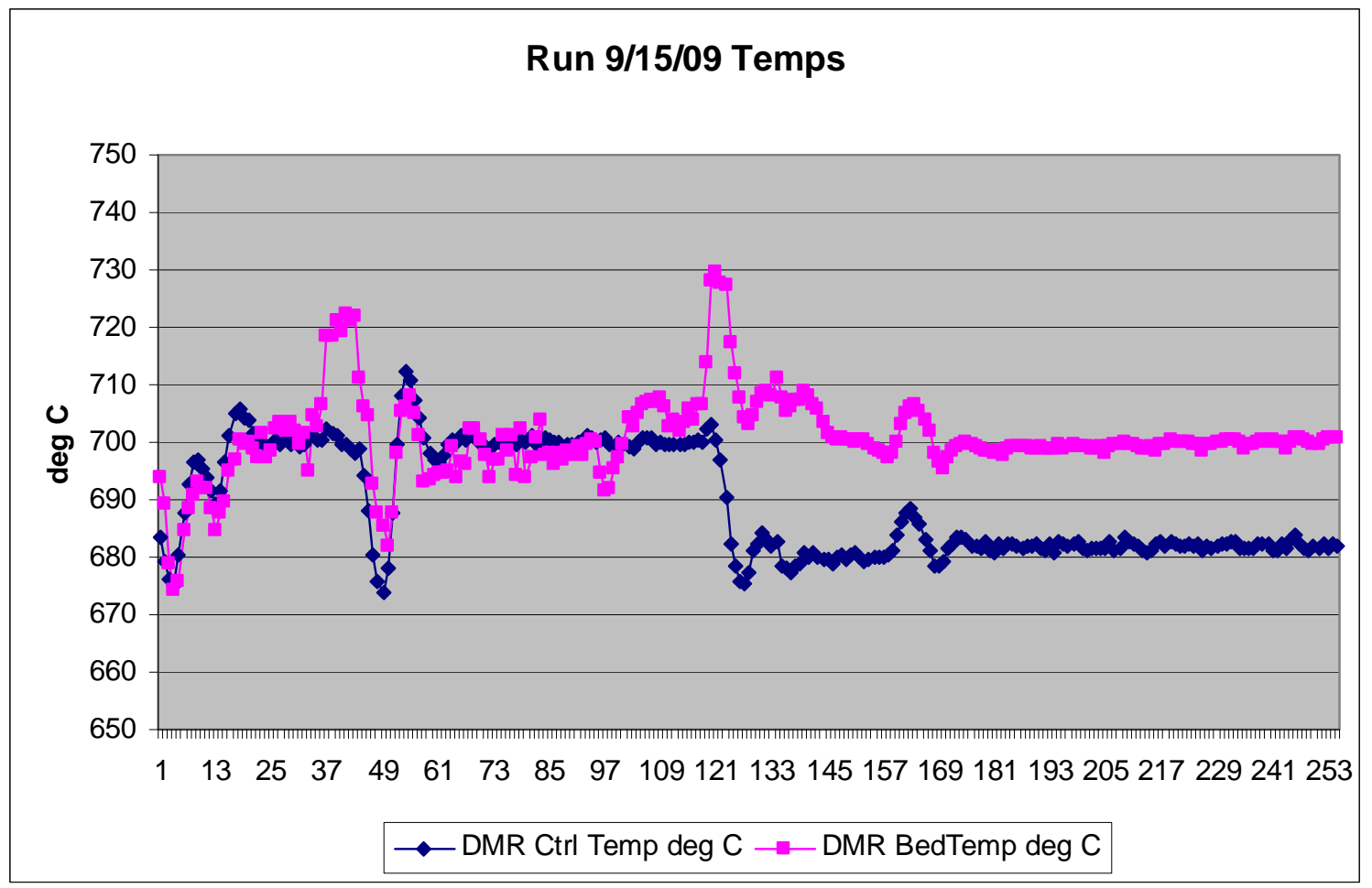

Figure B 9. Run 9/15/09 Temperatures in DMR

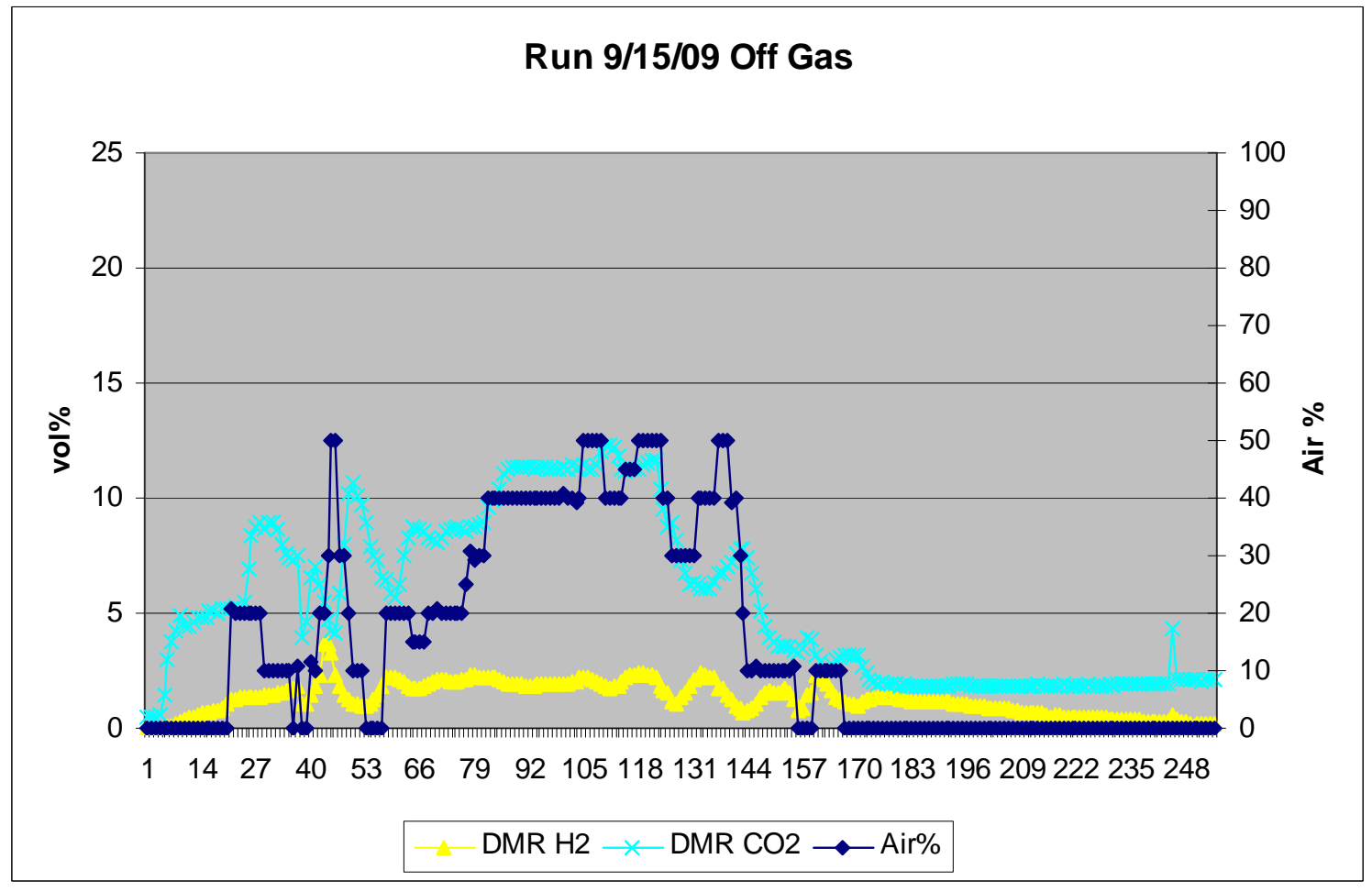

Figure B 10. Run 9/15/09 Off Gas Concentrations and Air\% Fed 


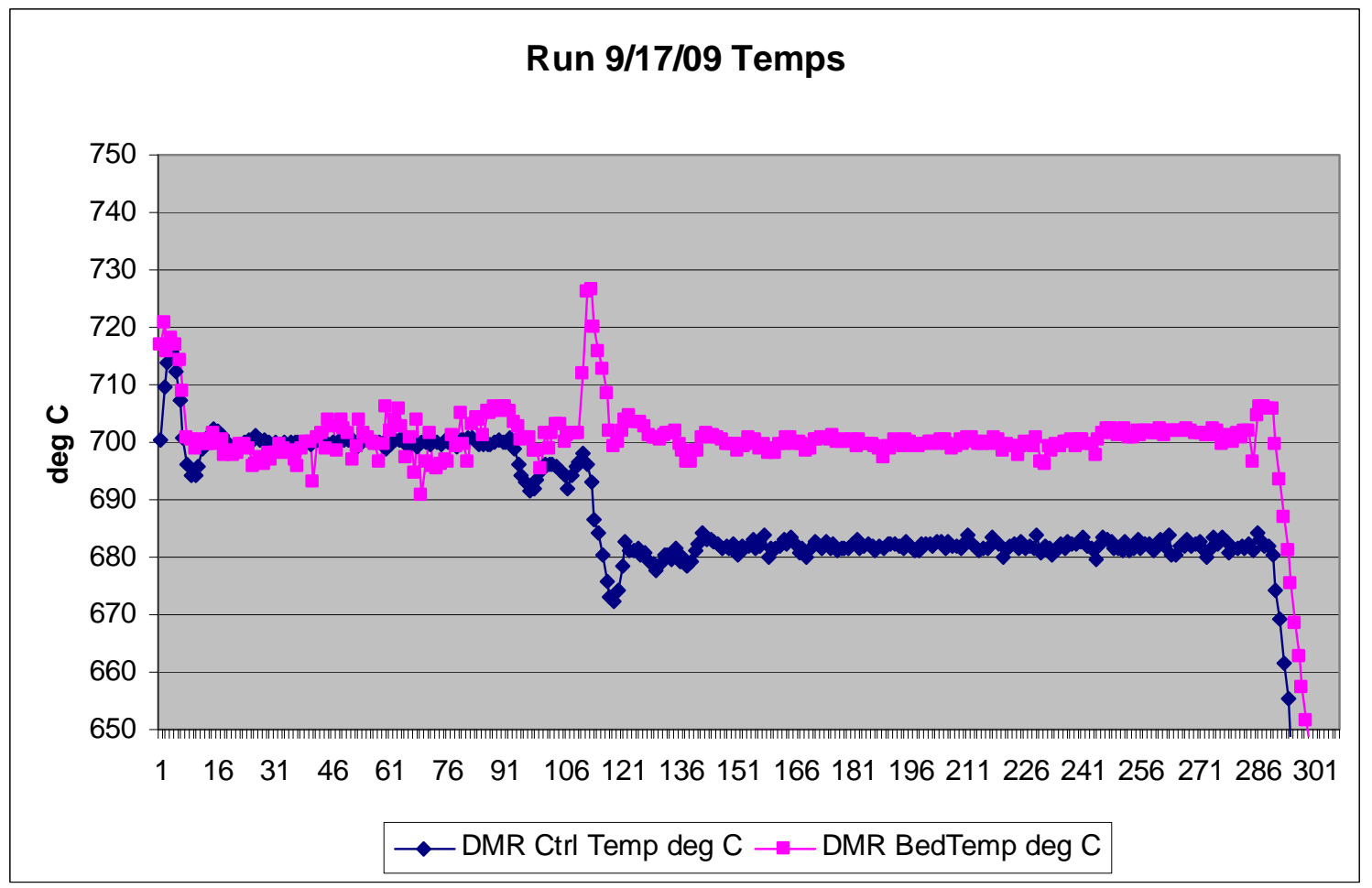

Figure B 11. Run 9/17/09 Temperatures in DMR

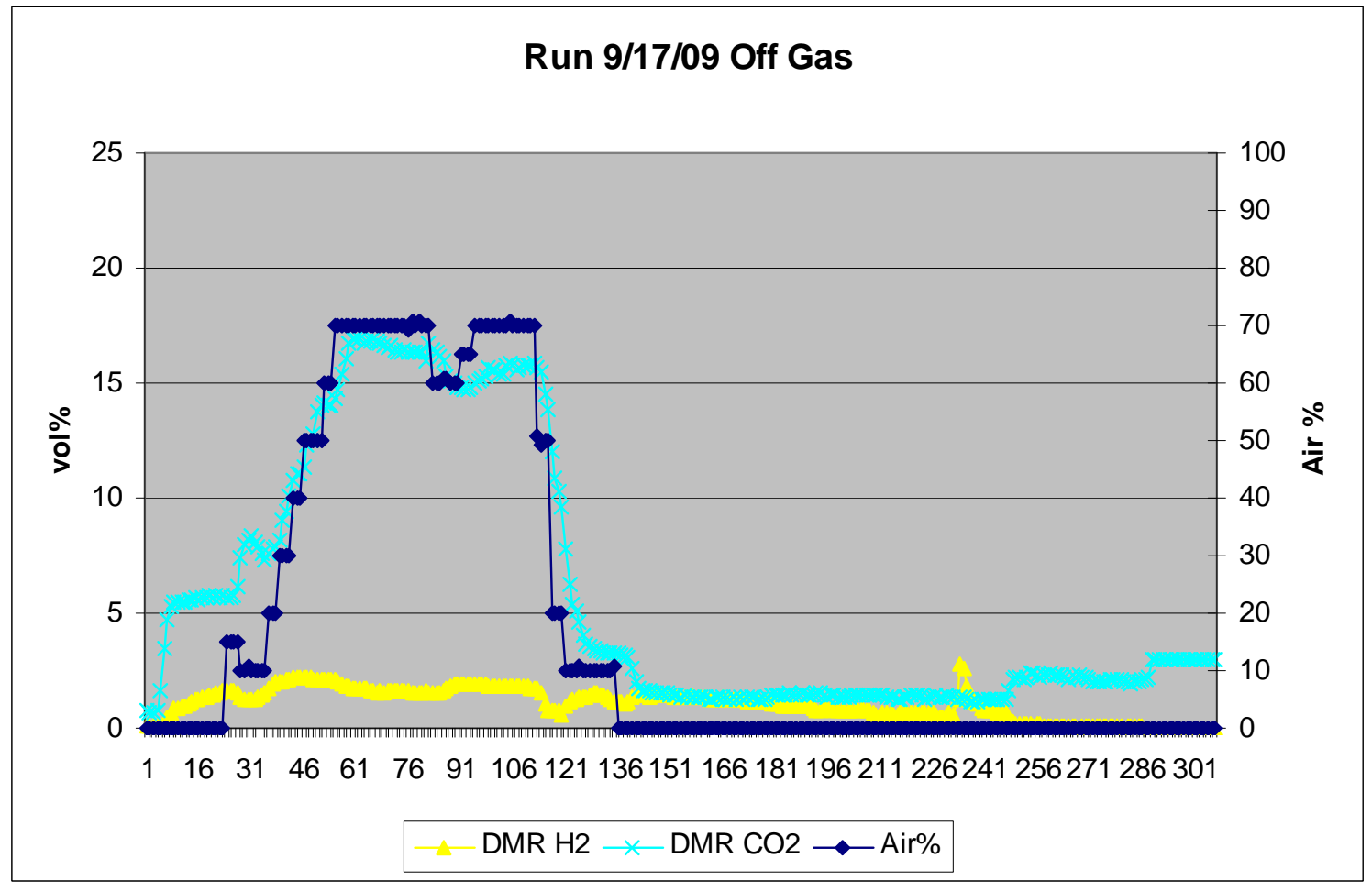

Figure B 12. Run 9/17/09 Off Gas Concentrations and Air\% Fed. 


\section{Appendix C. BSR Process Operation Conditions and trends for Simulant and RAD Runs, 2010}

Table C 1. BSR Process Operation Conditions for Simulant and RAD Runs, 2010

\begin{tabular}{|c|c|c|c|c|}
\hline Run Date & $8 / 18 / 10$ & $8 / 23 / 10$ & $9 / 8 / 10$ & $9 / 13 / 10$ \\
\hline Run Type & SIM A & SIM A & RAD A & RAD A \\
\hline Slurry Feed Rate & $1 \mathrm{~mL} / \mathrm{min}$ & $0.8-1 \mathrm{~mL} / \mathrm{min}$ & $0.9-1.3 \mathrm{~mL} / \mathrm{min}$ & $0.9-1.3 \mathrm{~mL} / \mathrm{min}$ \\
\hline DMR Bed Temp while feeding & $700-705^{\circ} \mathrm{C}$ & $695-705^{\circ} \mathrm{C}$ & $720^{\circ} \mathrm{C}$ & $685-715^{\circ} \mathrm{C}$ \\
\hline Superheated Steam & $0.40 \mathrm{~g} / \mathrm{min}$ & $0.40 \mathrm{~g} / \mathrm{min}$ & $0.40 \mathrm{~g} / \mathrm{min}$ & $0.40 \mathrm{~g} / \mathrm{min}$ \\
\hline DMR Control Pressure & -3 inwc & -3 inwc & -3 inwc & -3 inwc \\
\hline Carbon & $\begin{array}{l}21.5 \mathrm{~g} / 250 \mathrm{~mL} \\
\text { feed } / \text { clay mixture } \\
(0.086 \mathrm{~g} \mathrm{C} / \mathrm{min})\end{array}$ & $\begin{array}{c}21.5 \mathrm{~g} / 250 \mathrm{~mL} \\
\text { feed/clay mixture } \\
(0.086 \mathrm{~g} \mathrm{C} / \mathrm{min}) \\
\end{array}$ & $\begin{array}{c}21.5 \mathrm{~g} / 250 \mathrm{~mL} \\
\text { feed/clay mixture } \\
(0.086 \mathrm{~g} \mathrm{C} / \mathrm{min})\end{array}$ & $\begin{array}{c}21.5 \mathrm{~g} / 250 \mathrm{~mL} \\
\text { feed/clay mixture } \\
(0.086 \mathrm{~g} \mathrm{C} / \mathrm{min})\end{array}$ \\
\hline Total Controlled Gas Flow & $500 \mathrm{sccm}$ & $500 \mathrm{sccm}$ & $500 \mathrm{sccm}$ & $500 \mathrm{sccm}$ \\
\hline $\mathrm{H}_{2}$ Concentration Control & $1.5-3.0 \%$ & $1.5-3.0 \%$ & $1.5-3.0 \%$ & $1.5-3.0 \%$ \\
\hline Post Feed Run Time (hrs) & 2.25 & 2.5 & 0 & 2 \\
\hline Product REDOX & 0.78 & 0.65 & 0.261 & 0.257 \\
\hline Product LOI & $4.34 \%$ & $1.72 \%$ & $1.79 \%$ & $1.48 \%$ \\
\hline $\begin{array}{l}\text { Product Quantity (g) before } \\
\text { sampling }\end{array}$ & 82.6 & 78.2 & 26.46 & 69.21 \\
\hline Feed Quantity (g) & 322 & 320.5 & 126.9 & 306.5 \\
\hline NOTES & $\begin{array}{l}\text { Feed pluggage, diluted } \\
\text { feed early in run }\end{array}$ & Used diluted feed & Air Leak & Air Leak \\
\hline
\end{tabular}

All off-gas conditioning included bubbler, 25 micron filter, then 2 micron filter. Temperature control is from top of reaction zone. 


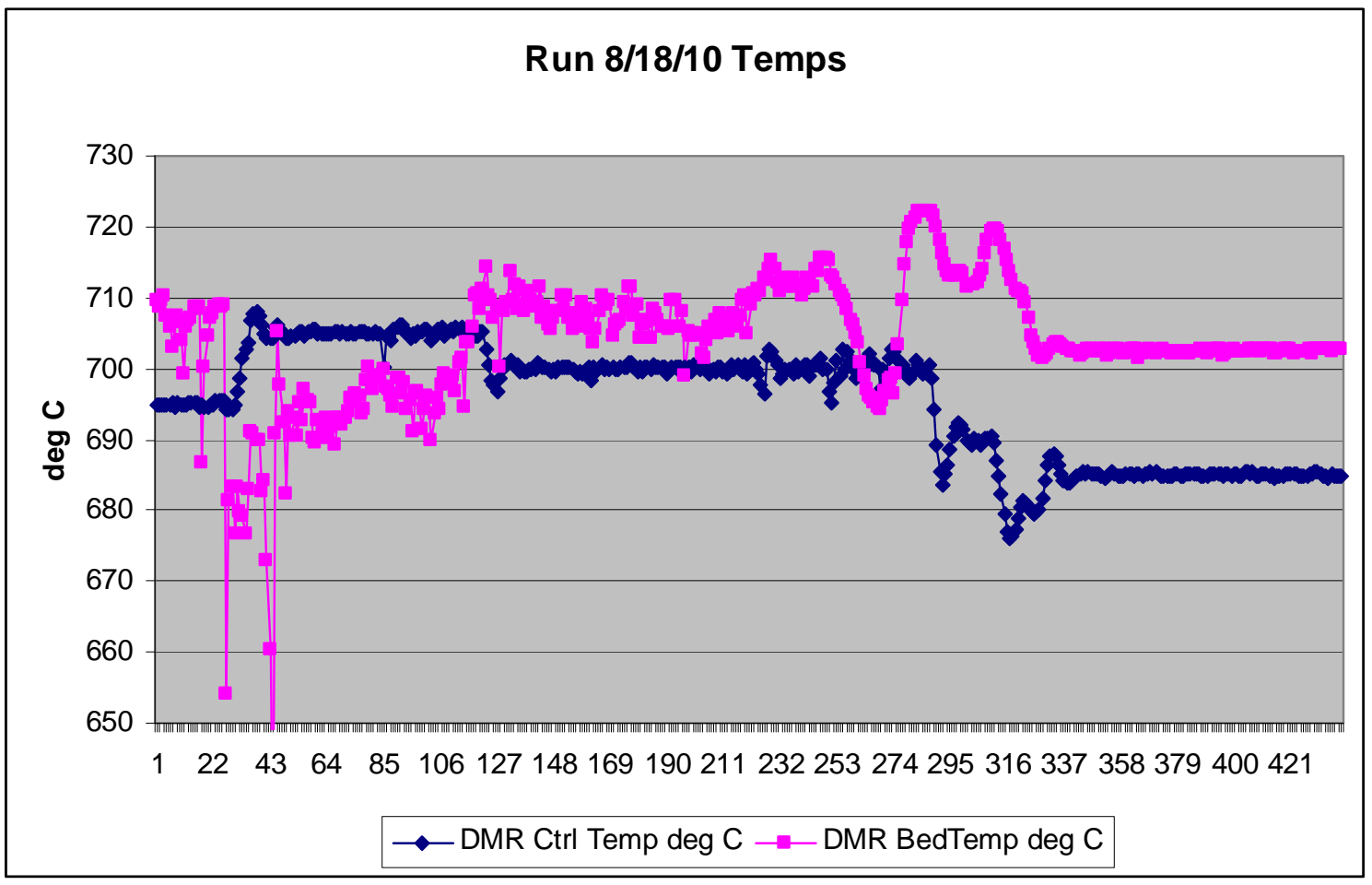

Figure C 1. Run 8/18/10 Temperatures in DMR

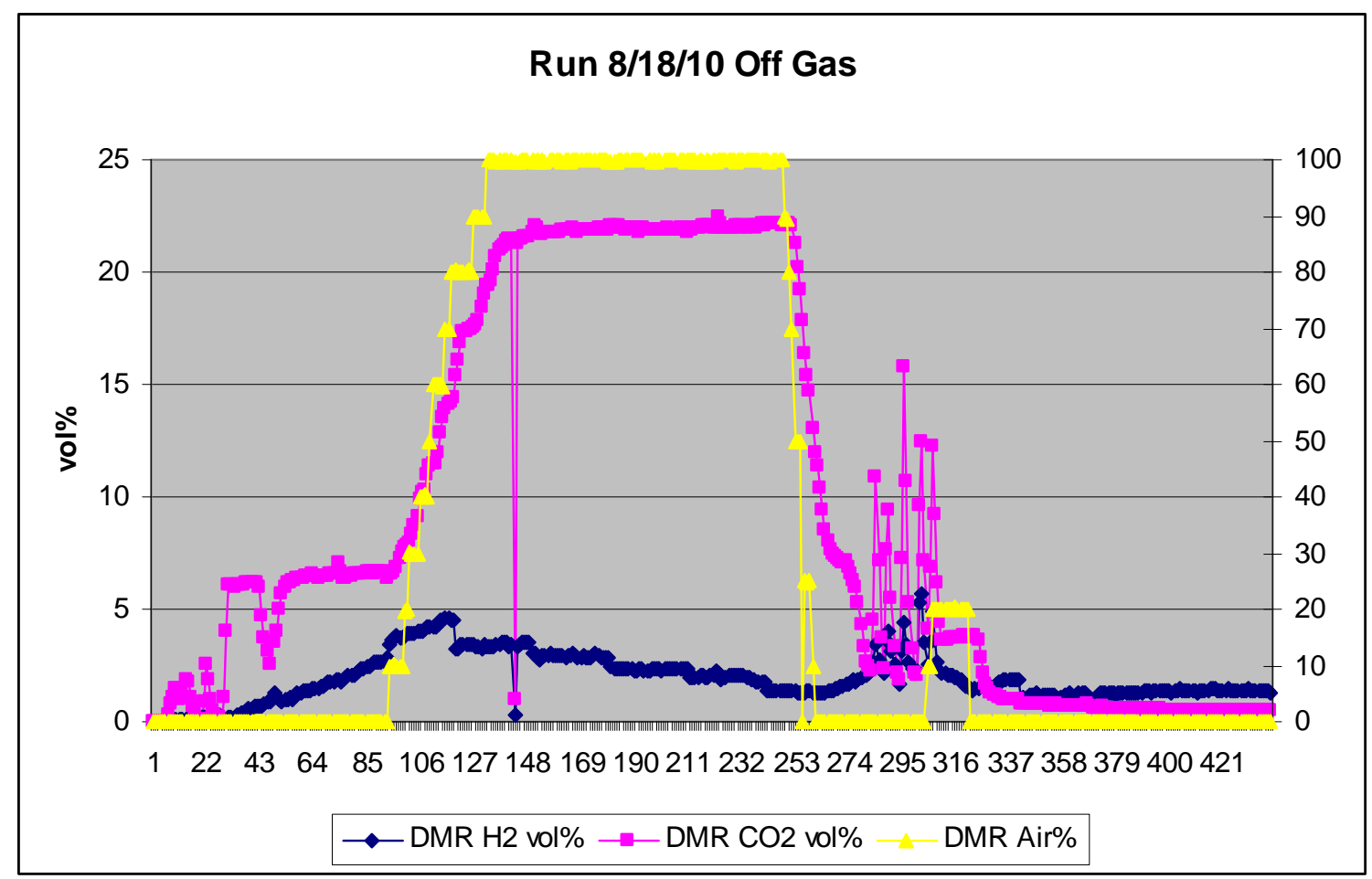

Figure C 2. Run 8/18/10 Off Gas Concentrations and Air\% Fed 


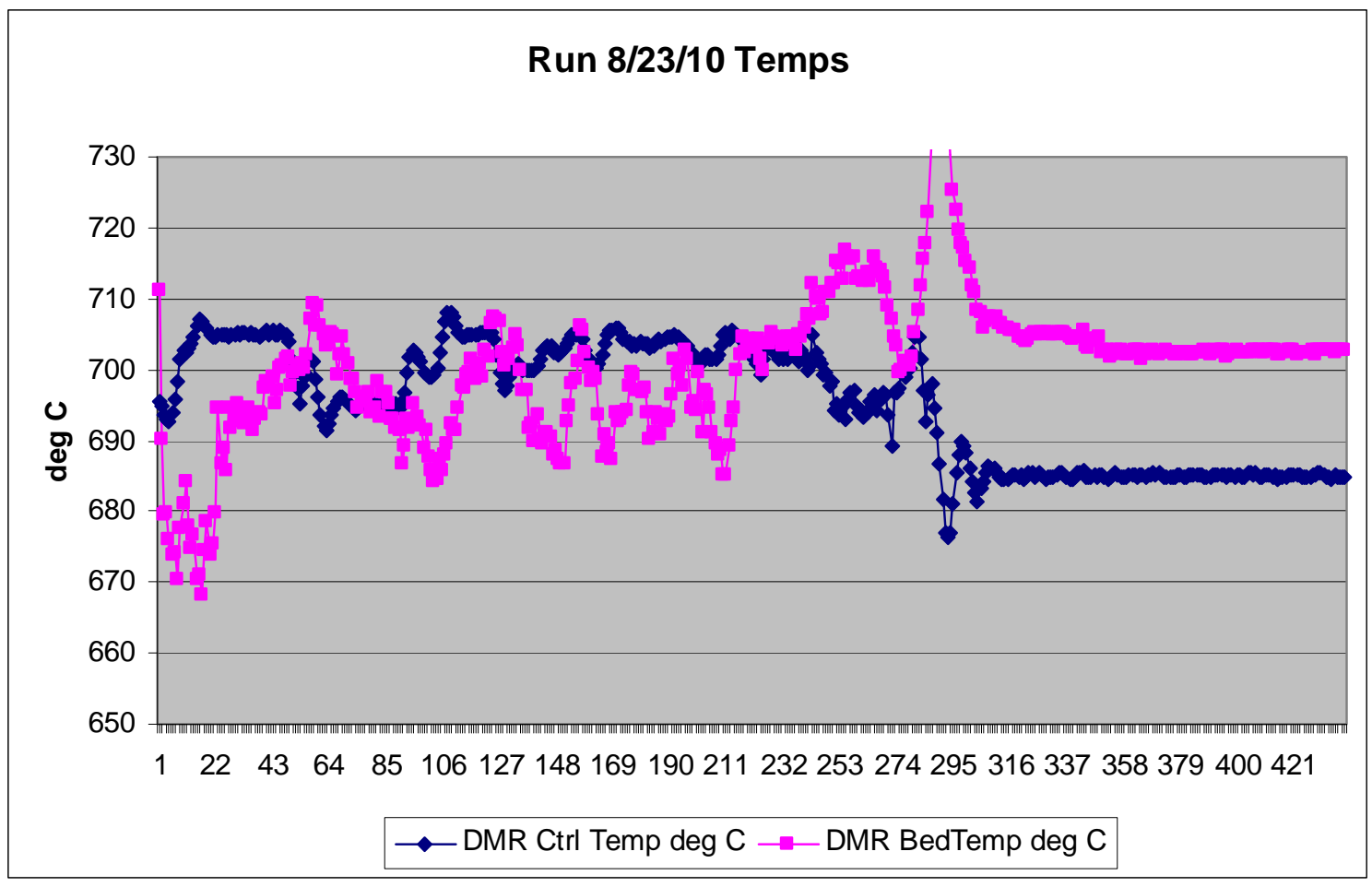

Figure C 3. Run 8/23/10 Temperatures in DMR

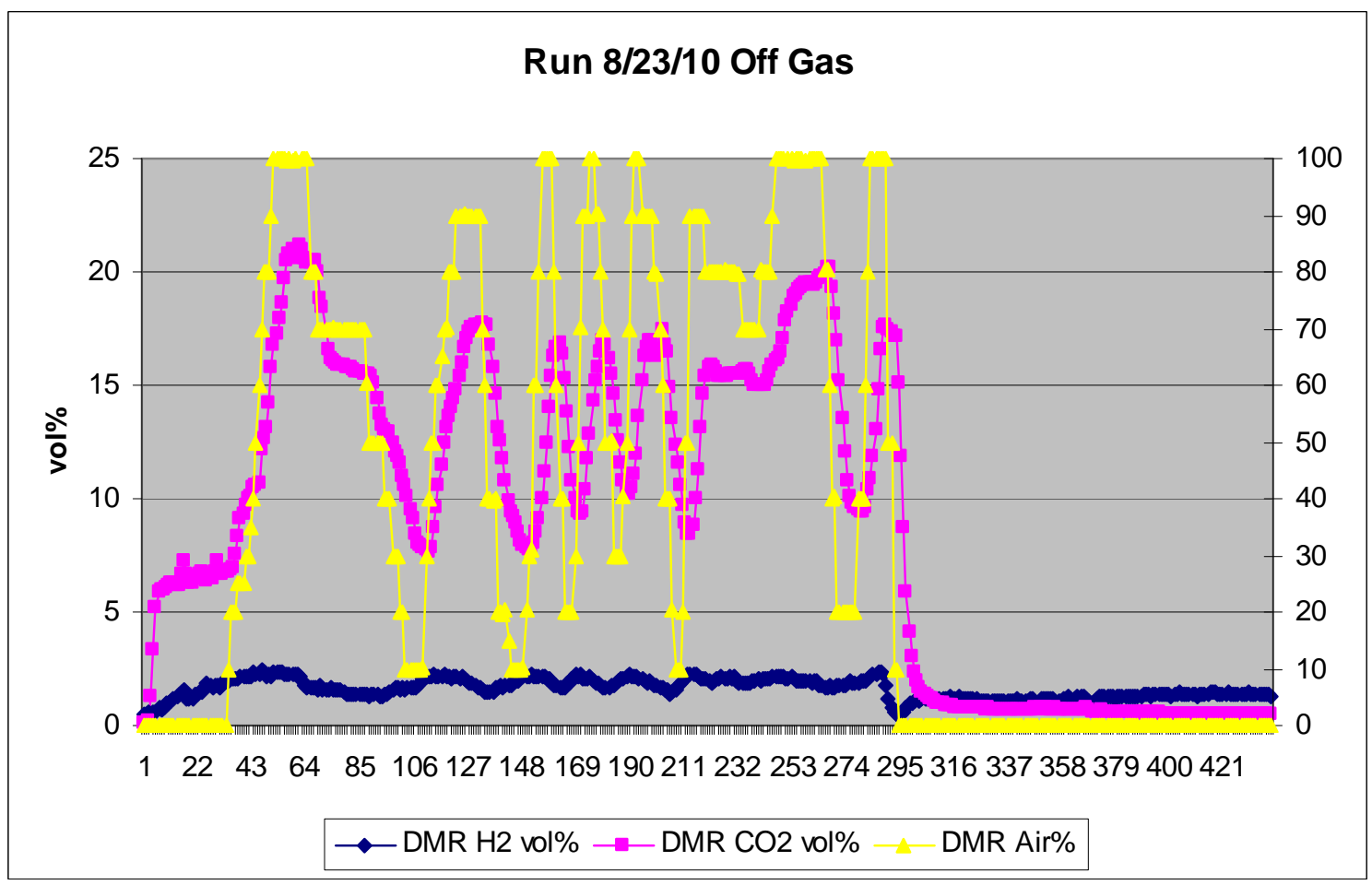

Figure C 4. Run 8/23/10 Off Gas Concentrations and Air\% Fed 


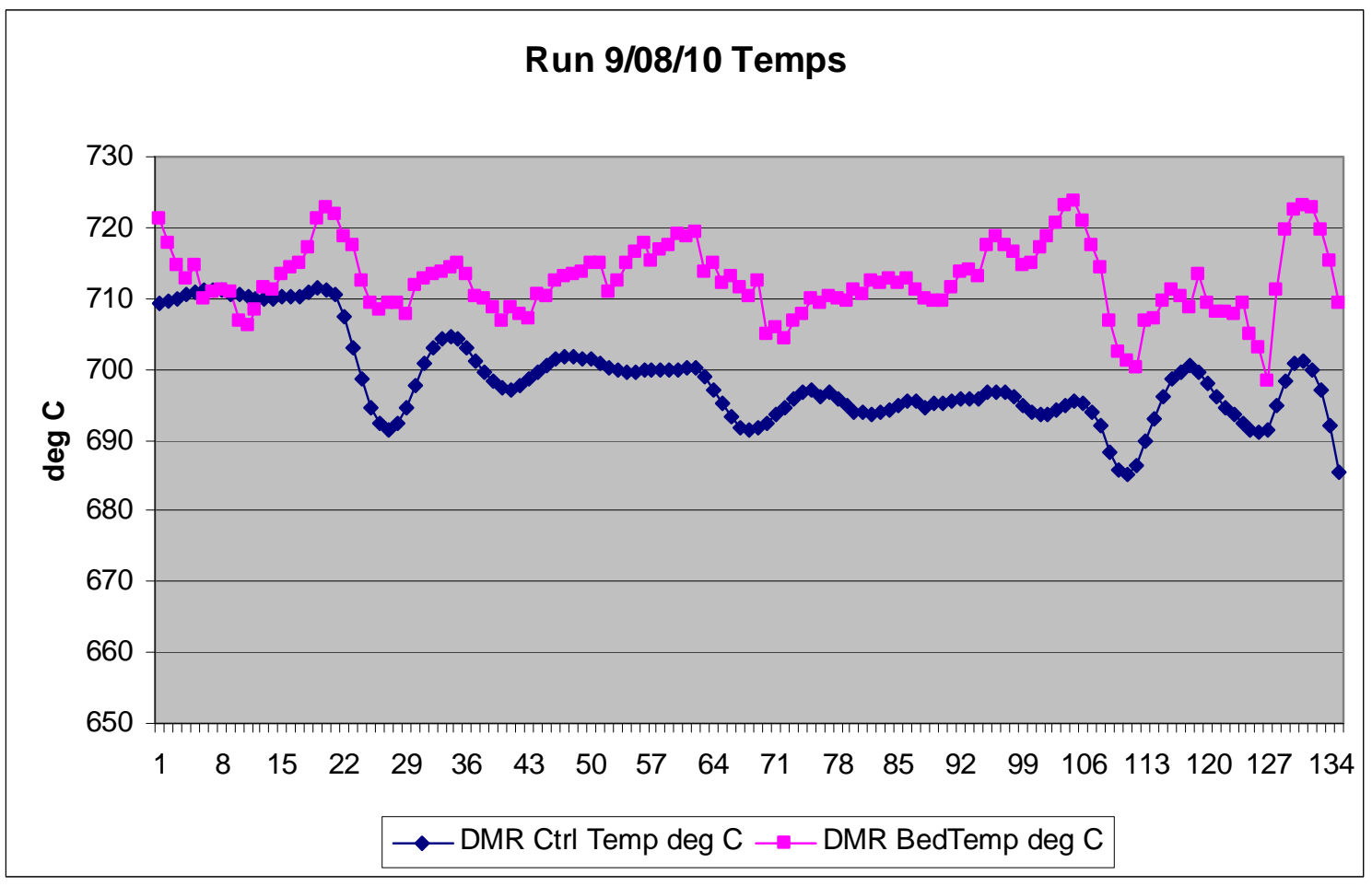

Figure C 5. Radioactive Run 9/08/10 Temperatures in DMR

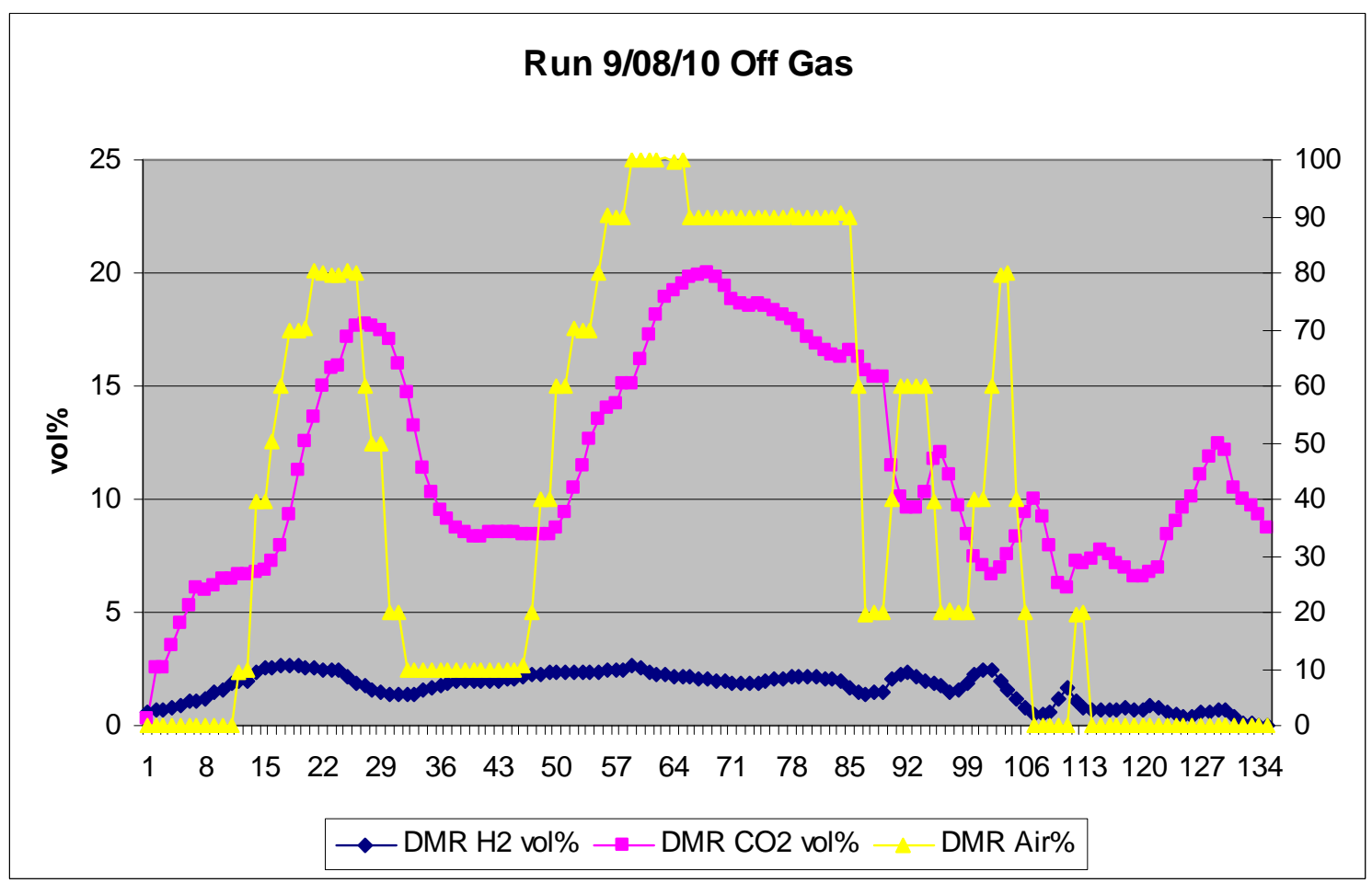

Figure C 6. Radioactive Run 9/08/10 Off Gas Concentrations and Air\% Fed 


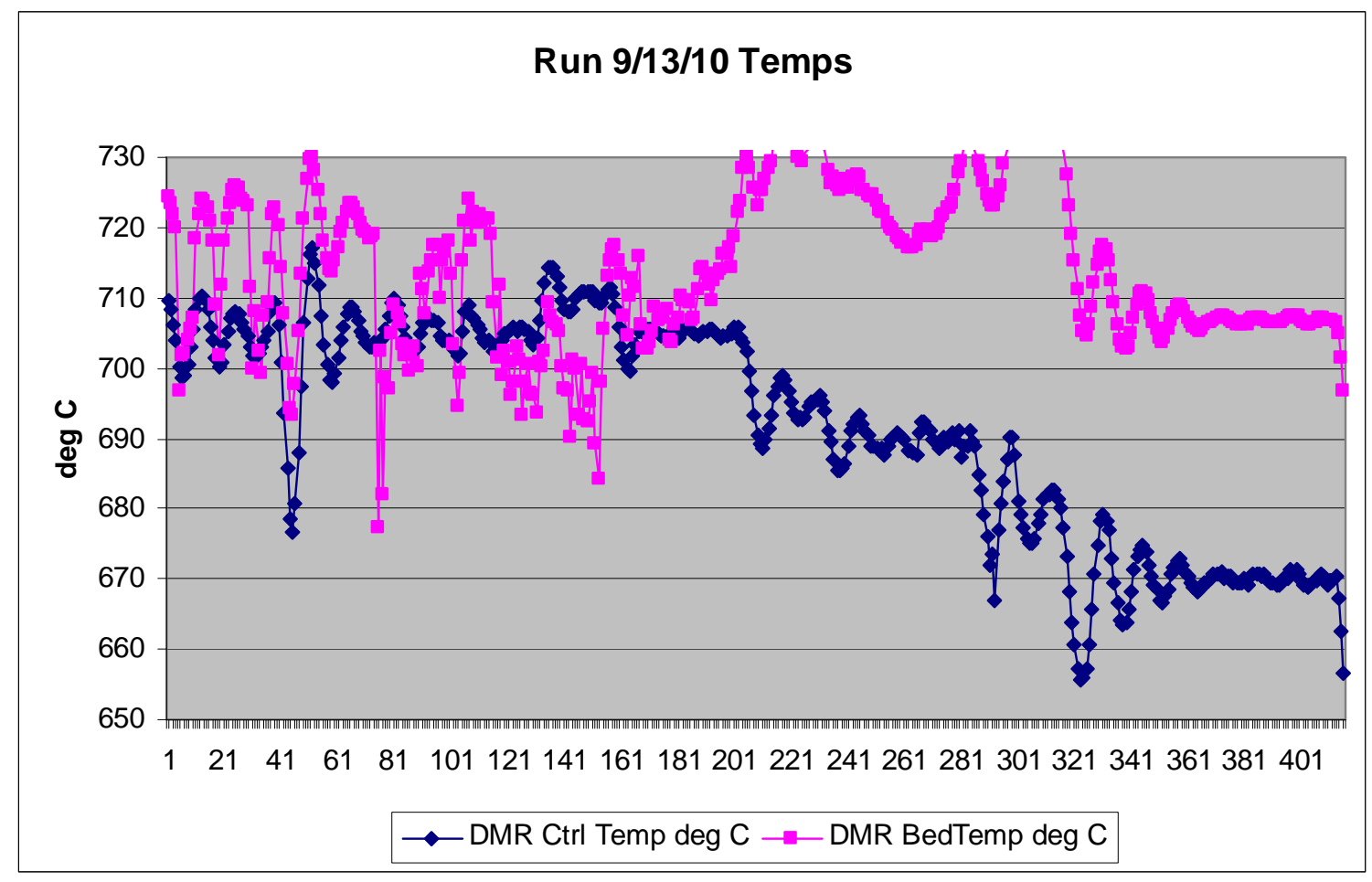

Figure C 7. Radioactive Run 9/13/10 Temperatures in DMR

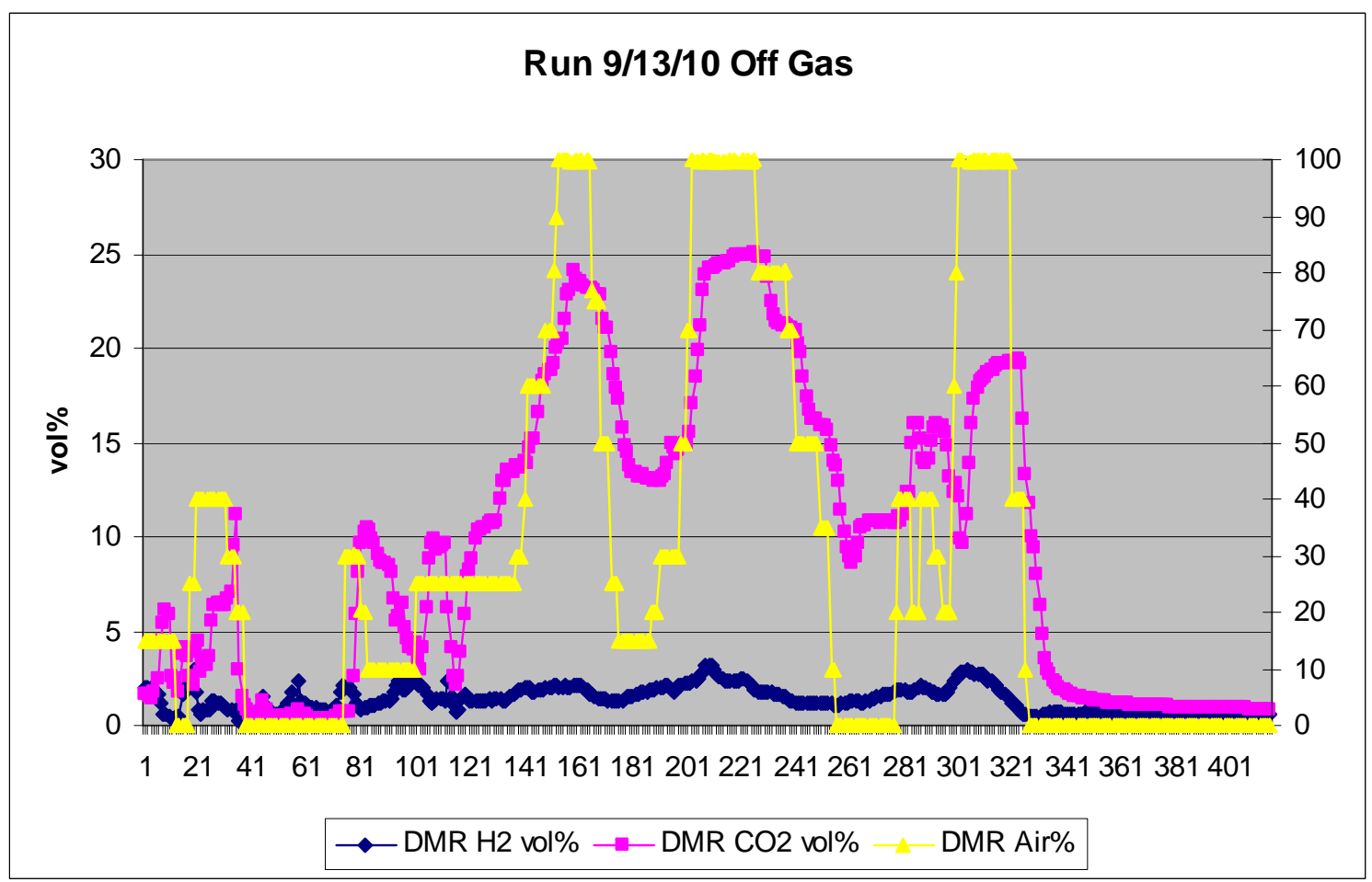

Figure C 8. Radioactive Run 9/13/10 Off Gas Concentrations and Air\% Fed 


\section{Appendix D. BSR Process Operation Conditions and Trends for Simulant Re-Runs, 2011}

Table D 1. BSR Process Operation Conditions for Simulant Re-Runs, 2011

\begin{tabular}{|c|c|c|c|c|c|}
\hline Run Date & $3 / 1 / 11$ & $3 / 3 / 11$ & $3 / 4 / 11$ & $3 / 7 / 11$ & $3 / 8 / 11$ \\
\hline Slurry Feed Rate & $1 \mathrm{~mL} / \mathrm{min}$ & $1 \mathrm{~mL} / \mathrm{min}$ & $1 \mathrm{~mL} / \mathrm{min}$ & $1 \mathrm{~mL} / \mathrm{min}$ & $1 \mathrm{~mL} / \mathrm{min}$ \\
\hline $\begin{array}{l}\text { DMR Bed Temp } \\
\text { while feeding }\end{array}$ & $\begin{array}{l}690- \\
730^{\circ} \mathrm{C}\end{array}$ & $714-725^{\circ} \mathrm{C}$ & $713-730^{\circ} \mathrm{C}$ & $708-732^{\circ} \mathrm{C}$ & $720-745^{\circ} \mathrm{C}$ \\
\hline Superheated Steam & $\begin{array}{c}0.40 \\
\mathrm{~g} / \mathrm{min}\end{array}$ & $\begin{array}{c}0.40 \\
\mathrm{~g} / \mathrm{min}\end{array}$ & $\begin{array}{c}0.40 \\
\mathrm{~g} / \mathrm{min}\end{array}$ & $\begin{array}{c}0.40 \\
\mathrm{~g} / \mathrm{min}\end{array}$ & $\begin{array}{c}0.40 \\
\mathrm{~g} / \mathrm{min}\end{array}$ \\
\hline $\begin{array}{l}\text { DMR Control } \\
\text { Pressure }\end{array}$ & -4 inwe & -4 inwe & -4 inwe & -4 inwe & -4 inwc \\
\hline Carbon & $1.3 \mathrm{x}$ & $1.5 \mathrm{x}$ & $1.5 \mathrm{x}$ & $1.5 \mathrm{x}$ & $1.5 \mathrm{x}$ \\
\hline $\begin{array}{l}\text { Total Controlled Gas } \\
\text { Flow }\end{array}$ & $500 \mathrm{sccm}$ & $500 \mathrm{sccm}$ & $500 \mathrm{sccm}$ & $500 \mathrm{sccm}$ & $500 \mathrm{sccm}$ \\
\hline Air\% during feed & $20 \%$ & $22 \%$ & $22-23 \%$ & $22 \%$ & $21 \%$ \\
\hline $\mathrm{CO} 2 / \mathrm{mL}$ & 10.9 & 13.25 & 13.08 & 13.26 & 9.7 \\
\hline Product REDOX & 0.19 & 0.23 & 0.18 & 0.18 & 0.15 \\
\hline Product LOI - LOD & $0.36 \%$ & $0.69 \%$ & $0.67 \%$ & $0 \%$ & $0.08 \%$ \\
\hline $\begin{array}{l}\text { Product Quantity (g) } \\
\text { before sampling }\end{array}$ & 22.58 & 28.66 & 28.84 & 24.67 & 25.82 \\
\hline Feed Quantity (g) & 80.2 & 102.8 & 103.5 & 88.5 & 92.6 \\
\hline NOTES & & & & & \\
\hline
\end{tabular}




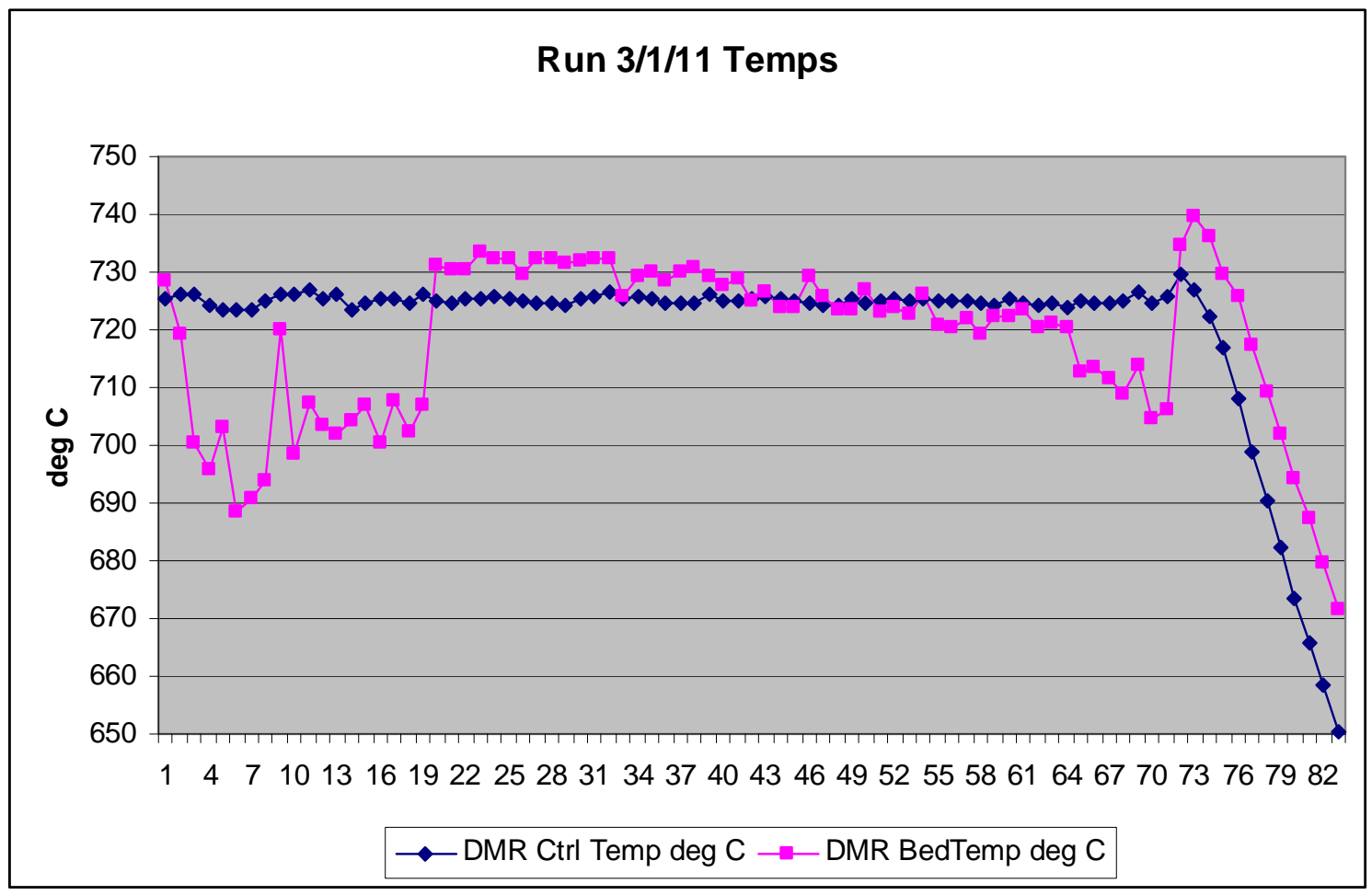

Figure D 1. Run 3/1/11 Temperatures in DMR

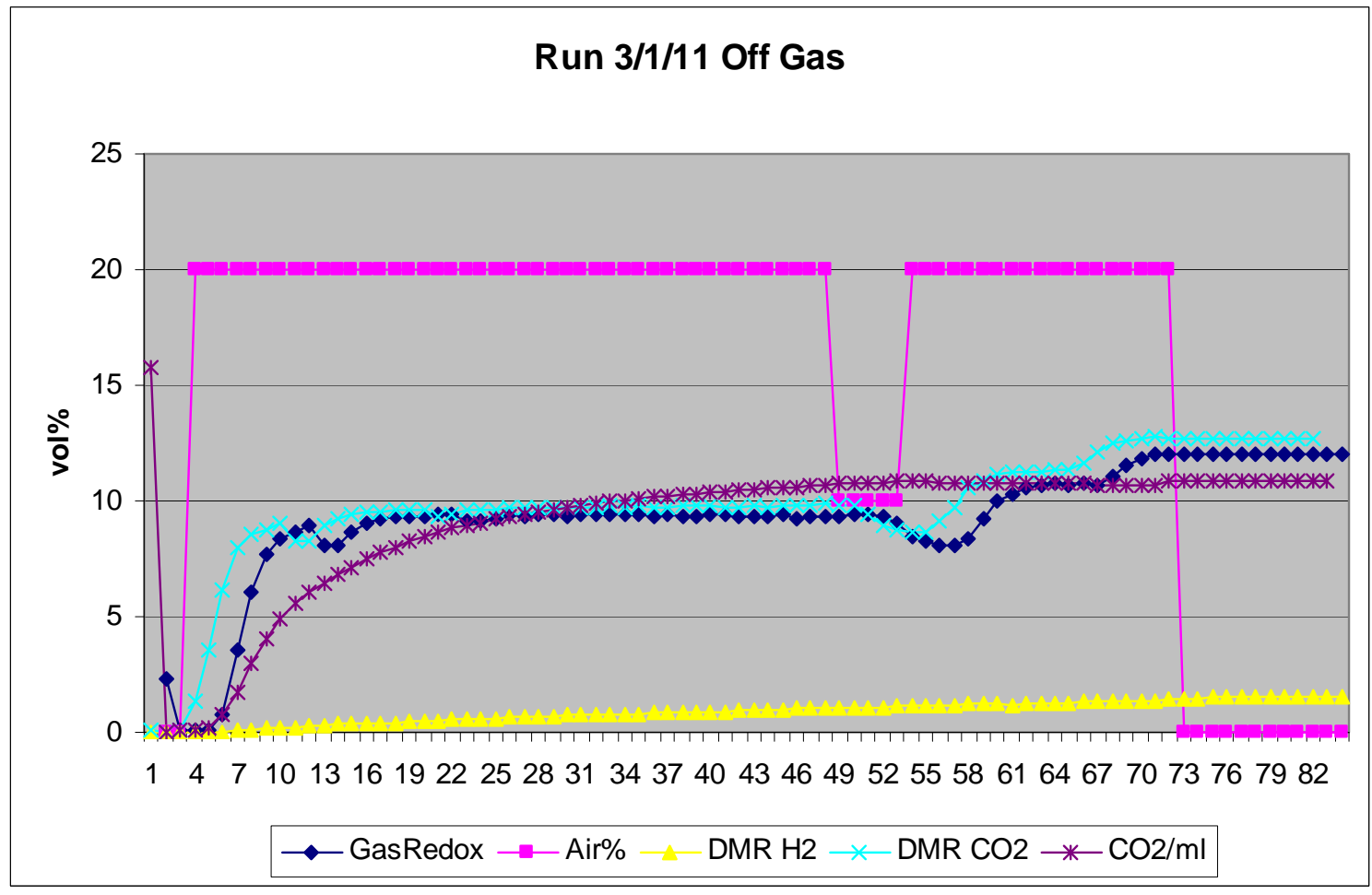

Figure D 2. Run 3/1/11 Off Gas Concentrations and Air\% Fed 


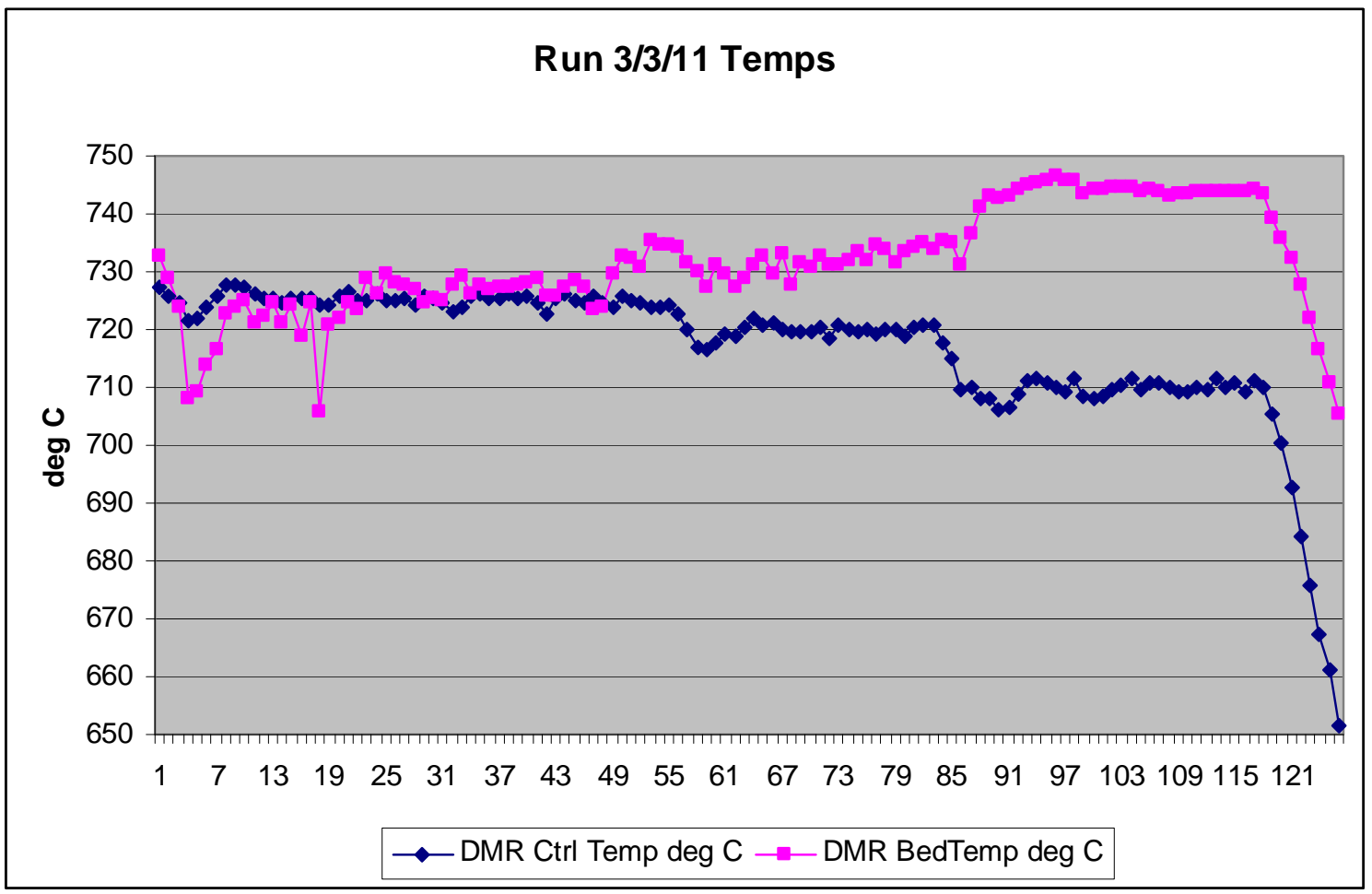

Figure D 3. Run 3/3/11 Temperatures in DMR

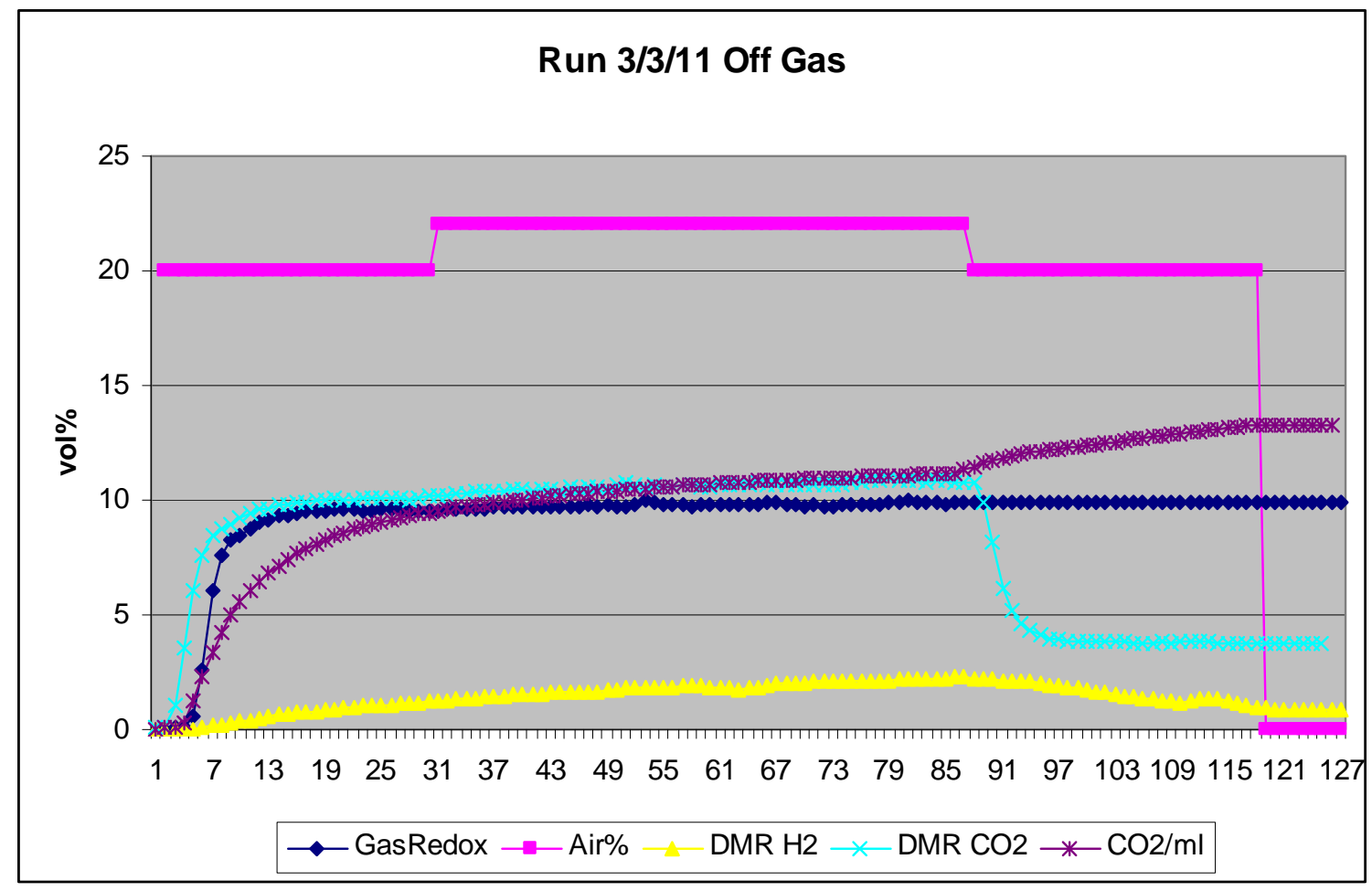

Figure D 4. Run 3/3/11 Off Gas Concentrations and Air\% Fed 


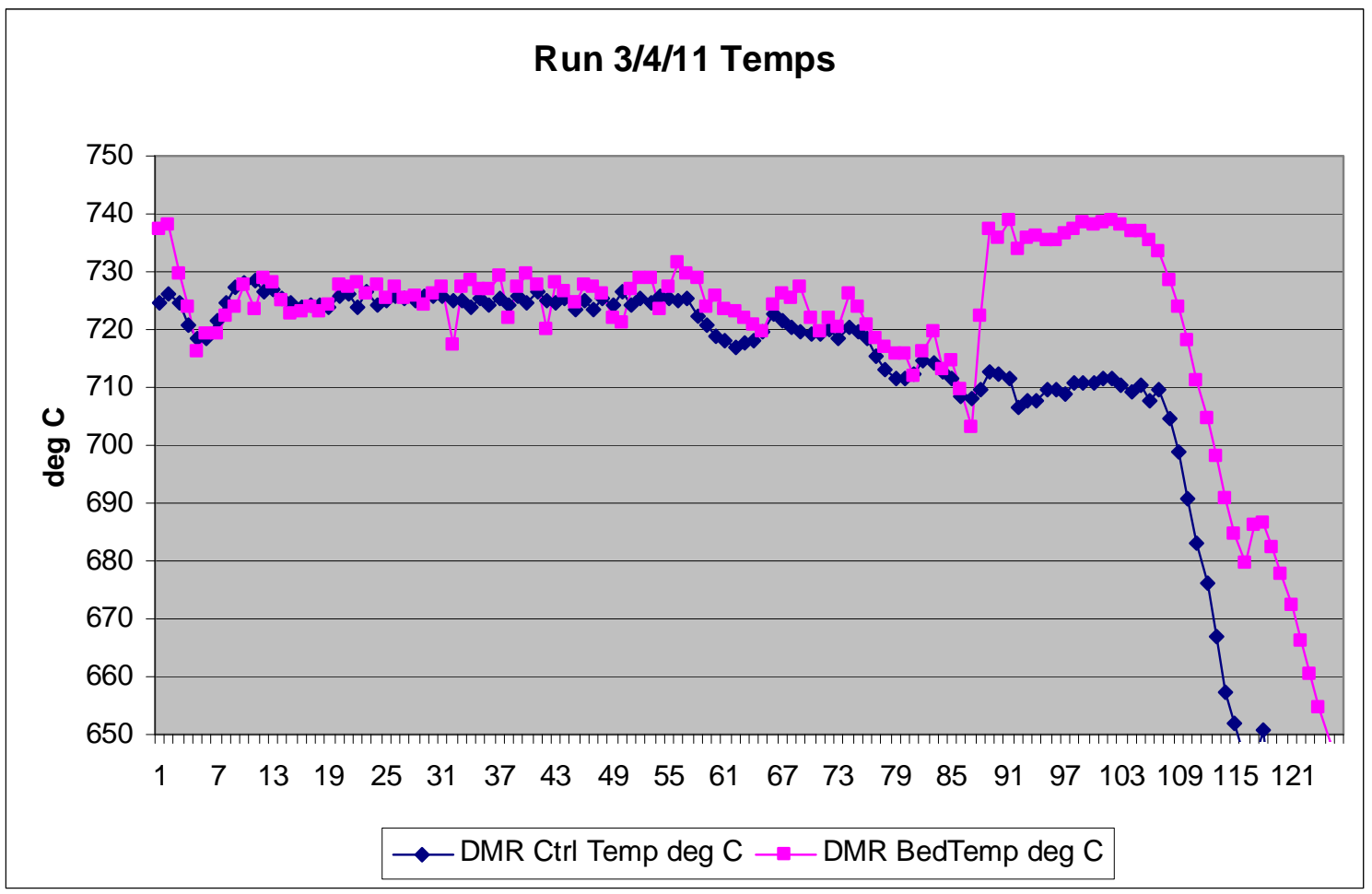

Figure D 5. Run 3/4/11 Temperatures in DMR

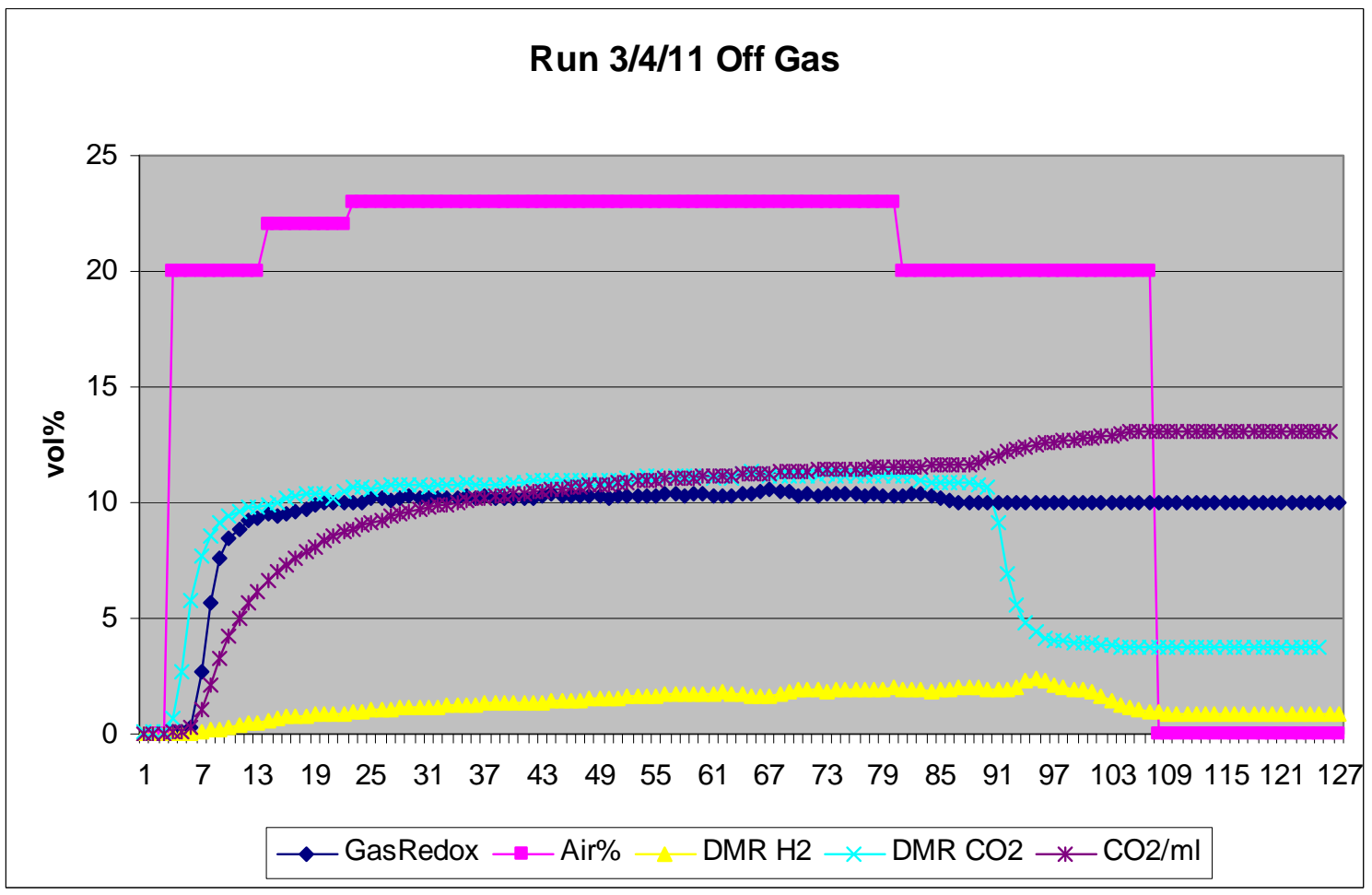

Figure D 6. Run 3/4/11 Off Gas Concentrations and Air\% Fed 


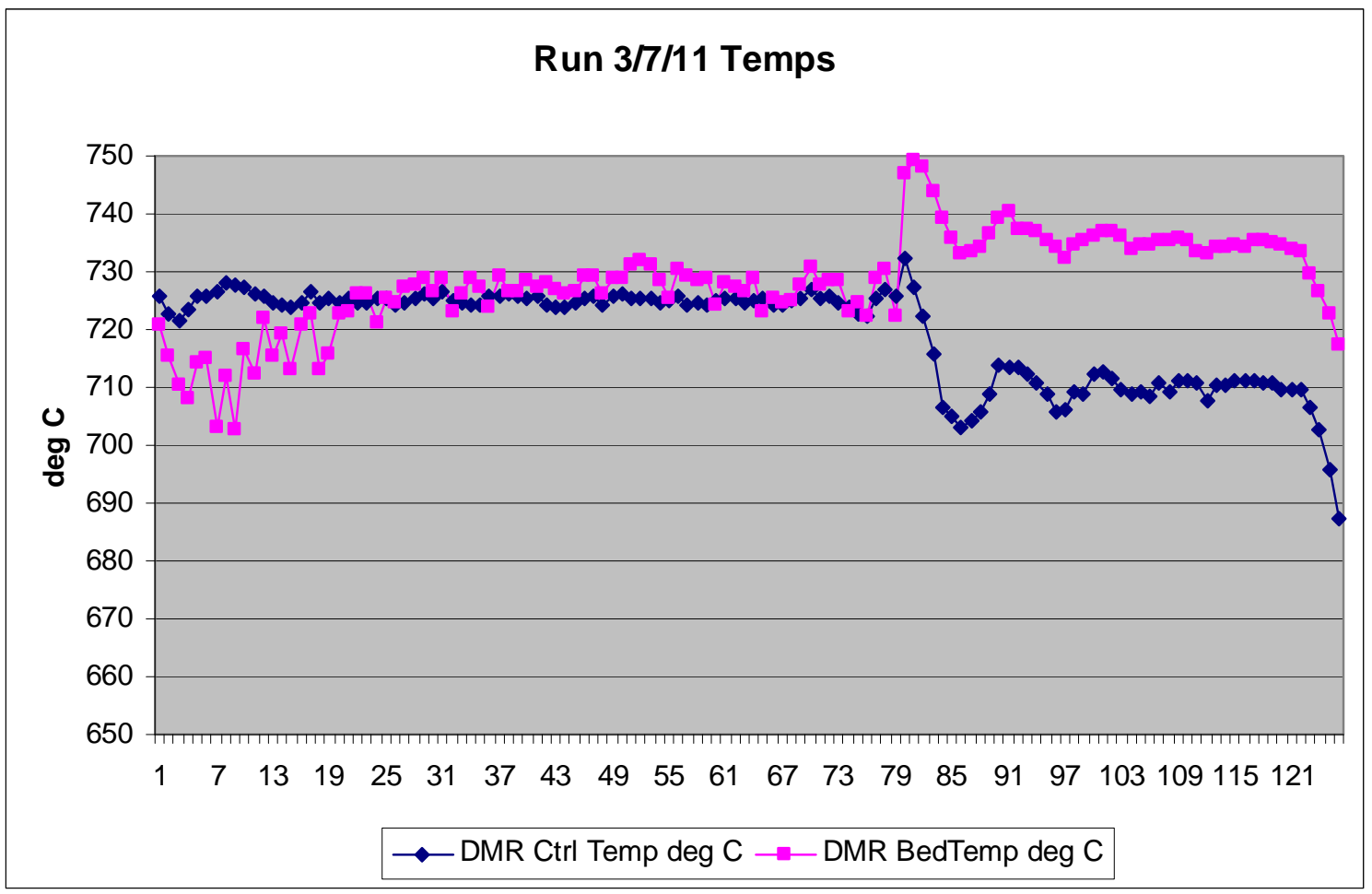

Figure D 7. Run 3/7/11 Temperatures in DMR

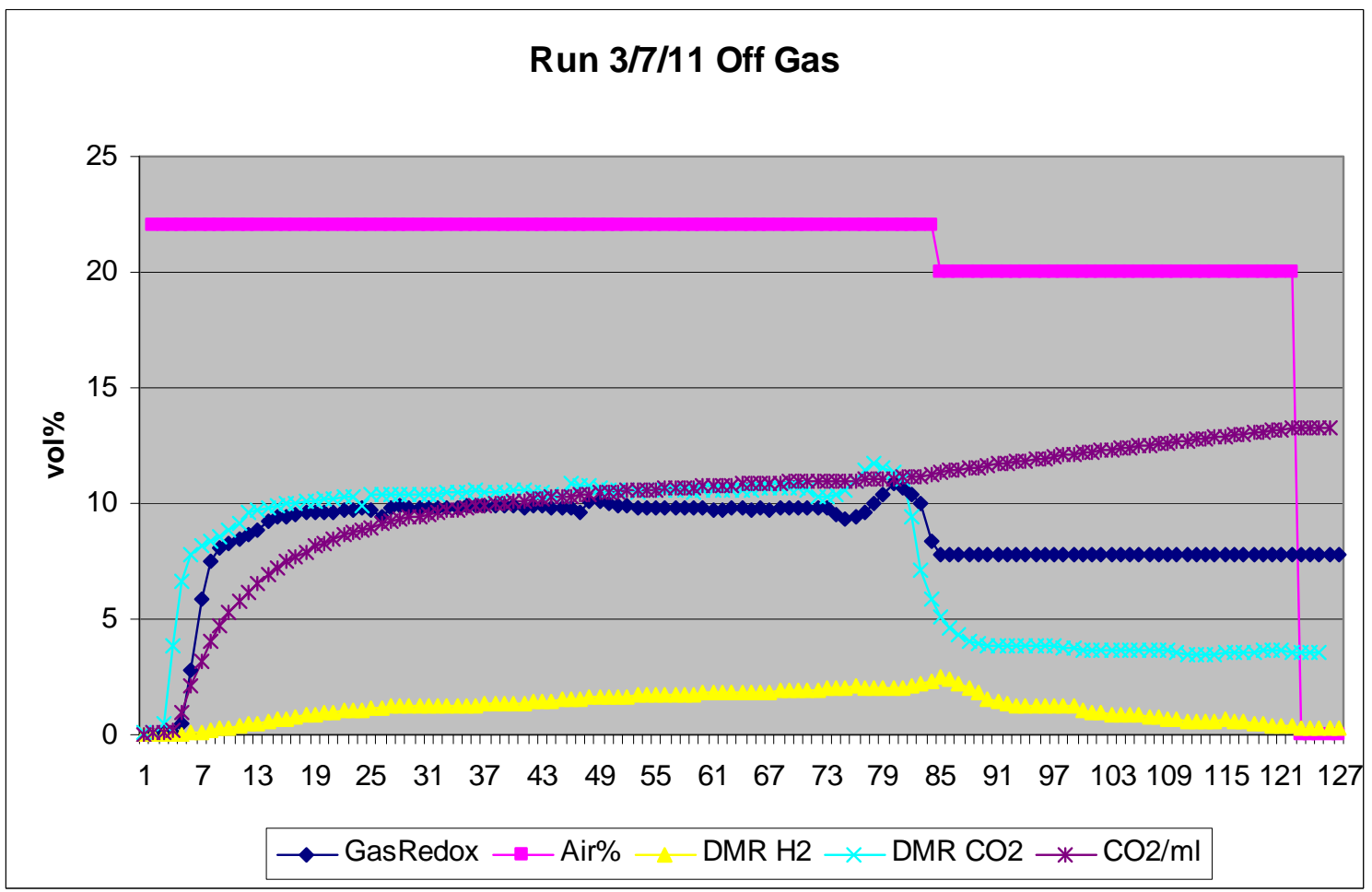

Figure D 8. Run 3/7/11 Off Gas Concentrations and Air\% Fed 


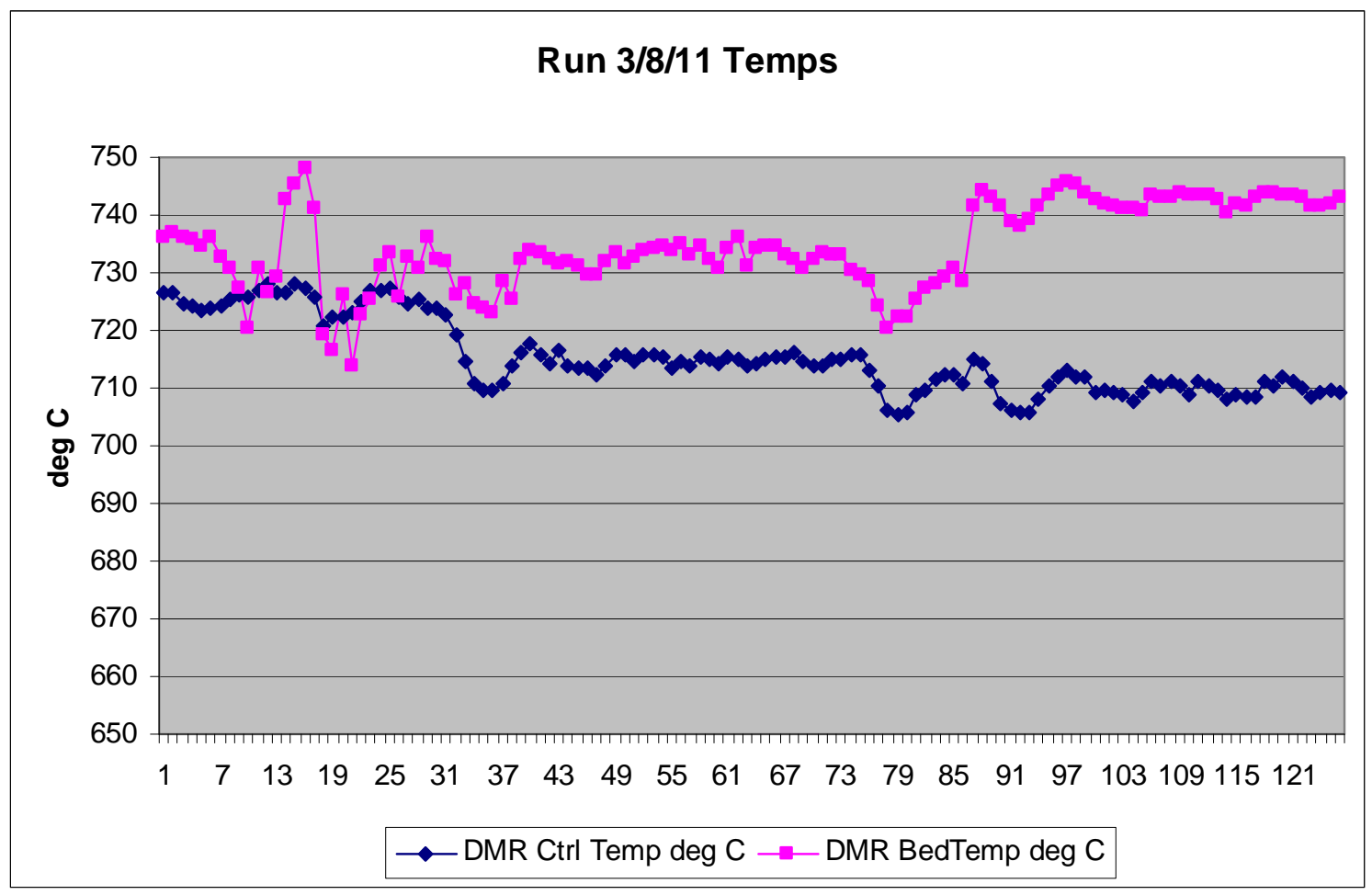

Figure D 9. Run 3/8/11 Temperatures in DMR

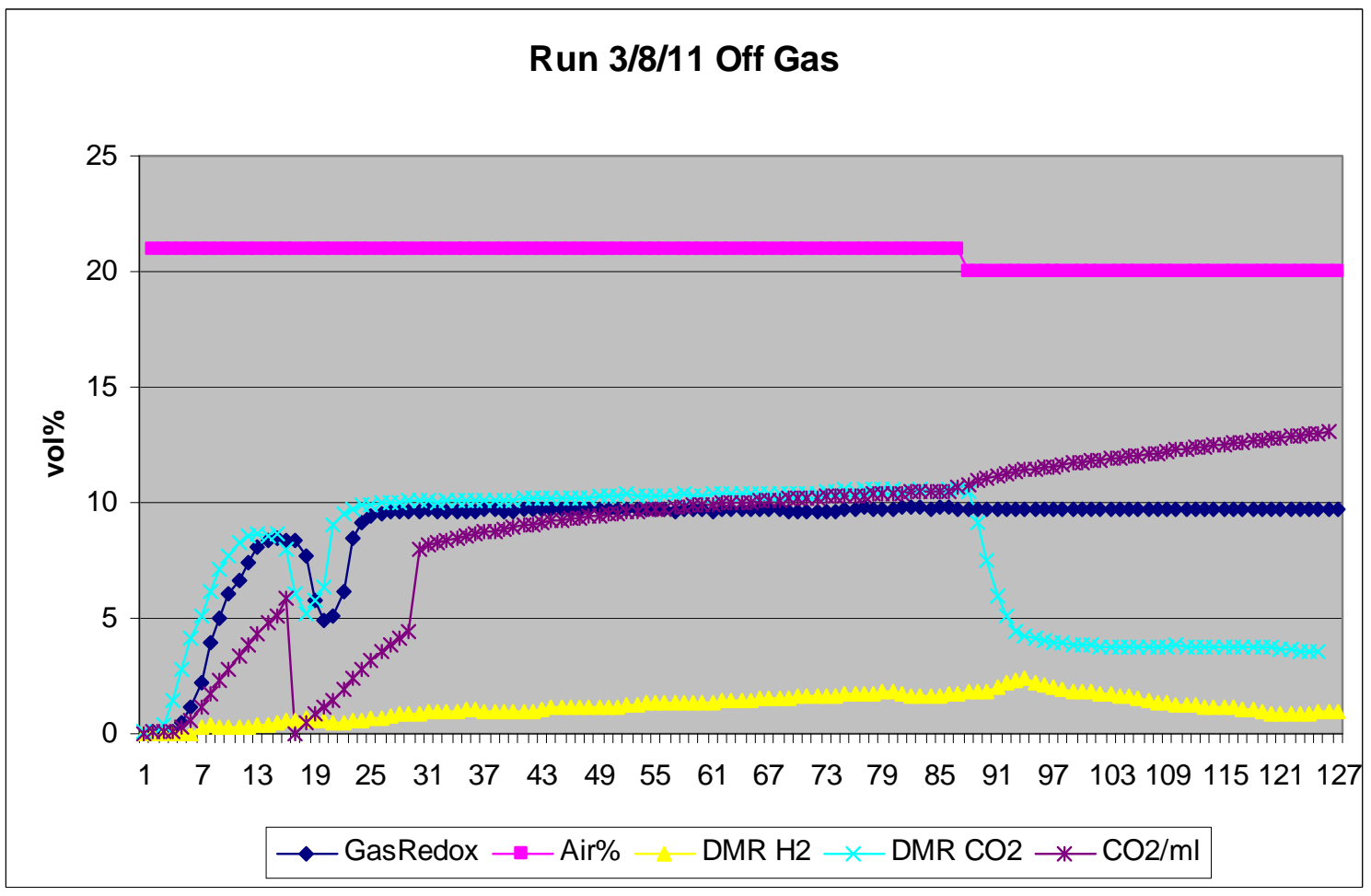

Figure D 10. Run 3/8/11 Off Gas Concentrations and Air\% Fed 


\section{Appendix E. Sample Analyses for Simulant WTP SW BSR Campaign in Fall 2010}

Table E 1. through Table E 3. give the ICPES, IC, and ICPMS concentrations for the Simulant A granular product samples. The average concentrations are used in the mass balance.

Table E 1. SIM A GRANULAR PRODUCT ICPES Ag-Zn

\begin{tabular}{|c|c|c|c|c|c|c|c|c|c|c|c|c|c|}
\hline \multirow{2}{*}{ Sample } & \multicolumn{13}{|c|}{ Elemental Concentration (wt\%) } \\
\hline & Ag & Al & As & B & $\mathbf{C r}$ & $\mathbf{K}$ & $\mathrm{Na}$ & $\mathbf{N i}$ & $\mathbf{P}$ & $\mathbf{P b}$ & $\mathbf{S}$ & Si & $\mathbf{Z n}$ \\
\hline 1 & $<0.00001$ & 15.10 & 0.0037 & 0.33 & 0.09 & 0.37 & 11.90 & 0.0016 & 0.07 & 0.0015 & 0.07 & 18.50 & 0.10 \\
\hline 2 & $<0.00001$ & 15.00 & 0.0038 & 0.33 & 0.09 & 0.37 & 11.90 & 0.0017 & 0.07 & 0.0013 & 0.07 & 18.40 & 0.10 \\
\hline 3 & $<0.00001$ & 15.60 & 0.0032 & 0.34 & 0.10 & 0.40 & 12.30 & 0.0017 & 0.08 & 0.0014 & 0.10 & 18.80 & 0.11 \\
\hline 4 & $<0.00001$ & 15.70 & 0.0038 & 0.34 & 0.10 & 0.40 & 12.40 & 0.0016 & 0.07 & 0.0014 & 0.10 & 18.80 & 0.11 \\
\hline 5 & & 16.40 & & & & 0.40 & 13.20 & & & & 0.09 & & 0.11 \\
\hline 6 & & 16.40 & & & & 0.44 & 13.20 & & & & 0.07 & & 0.11 \\
\hline 7 & & 16.50 & & & & 0.38 & 13.00 & & & & 0.13 & & 0.11 \\
\hline 8 & & 16.50 & & & & 0.37 & 13.10 & & & & 0.11 & & 0.11 \\
\hline Average & $<0.00001$ & 15.90 & 0.0036 & 0.33 & 0.10 & 0.39 & 12.63 & 0.0016 & 0.07 & 0.0014 & 0.09 & 18.63 & 0.11 \\
\hline Std. Dev. & na & 0.63 & 0.0003 & 0.01 & 0.004 & 0.02 & 0.57 & 0.00004 & 0.002 & 0.0001 & 0.02 & 0.21 & 0.00 \\
\hline$\%$ RSD & na & 3.98 & 7.33 & 1.98 & 3.72 & 5.95 & 4.48 & 2.57 & 2.68 & 6.64 & 23.15 & 1.11 & 3.97 \\
\hline
\end{tabular}

Table E 2. SIM A GRANULAR PRODUCT IC F-PO

\begin{tabular}{|c|l|l|l|l|l|l|}
\hline \multirow{2}{*}{ Sample } & \multicolumn{1}{|c|}{$\mathbf{w t} \%$} & $\mathbf{w t} \%$ & $\mathbf{w t} \%$ & $\mathbf{w t} \%$ & $\mathbf{w t} \%$ & \multicolumn{1}{c|}{$\mathbf{w t} \%$} \\
\cline { 2 - 7 } & \multicolumn{1}{|c|}{$\mathbf{F}$} & $\mathbf{C l}$ & $\mathbf{N} \mathbf{N}_{\mathbf{2}}$ & $\mathbf{N O}_{\mathbf{3}}$ & $\mathbf{S O}_{\mathbf{4}}$ & \multicolumn{1}{|c|}{$\mathbf{P O}_{\mathbf{4}}$} \\
\hline 1 & 0.20 & 0.57 & $<0.10$ & $<0.10$ & 0.19 & $<0.10$ \\
\hline 2 & 0.20 & 0.58 & $<0.10$ & $<0.10$ & 0.19 & $<0.10$ \\
\hline 3 & 0.14 & 0.45 & $<0.10$ & $<0.10$ & 0.27 & $<0.10$ \\
\hline Average & 0.14 & 0.47 & $<0.10$ & $<0.10$ & 0.27 & $<0.10$ \\
\hline Standard Deviation & 0.16 & 0.50 & $<0.10$ & $<0.10$ & 0.25 & $<0.10$ \\
\hline \%RSD & 0.04 & 0.07 & na & na & 0.04 & na \\
\hline
\end{tabular}

Table E 3. SIM A GRANULAR PRODUCT ICPMS Cs-Re

\begin{tabular}{|c|l|l|}
\hline \multirow{2}{*}{ Sample } & \multicolumn{2}{|c|}{ wt\% in product } \\
\cline { 2 - 3 } & \multicolumn{1}{|c|}{ Cs } & \multicolumn{1}{|c|}{ Re } \\
\hline 1 & 0.42 & 0.06 \\
\hline 2 & 0.42 & 0.07 \\
\hline 3 & 0.42 & \\
\hline 4 & 0.41 & \\
\hline Average & 0.42 & 0.07 \\
\hline Standard Deviation & 0.004 & 0.004 \\
\hline \%RSD & 1.03 & 5.65 \\
\hline
\end{tabular}

The DMR condensate filtrate cation or ICPES concentrations from the two runs for Simulant A module are shown in Table E 4. The DMR condensate filtrates can be represented as one volume of $0.749 \mathrm{~L}$ with composite concentrations based on the individual run averages times the volume per run. For example, the aluminum composite concentration in $\mathrm{mg} / \mathrm{L}$ is calculated as: 


$$
c f_{A l}=\frac{(0.377 * 1.89 E+00)+(0.372 * 3.38 E+01)}{0.377+0.372}=\frac{1.33 E+01}{0.749}=1.77 E+01
$$

The cation or ICPES concentrations based on this method for the DMR condensate composite filtrate are shown in Table E 5 and these values are used in the mass balance. 
Table E 4. SIM A DMR CONDENSATE FILTRATES ICPES Ag-Zn

\begin{tabular}{|c|c|c|c|c|c|c|c|c|c|c|c|c|c|c|c|}
\hline \multirow{2}{*}{ Run } & \multirow{2}{*}{$\frac{\text { L }}{\text { Vol. }}$} & \multirow{2}{*}{ Sample } & \multicolumn{13}{|c|}{ Elemental Concentration (mg/L) } \\
\hline & & & Ag & Al & As & $\mathbf{B}$ & $\mathbf{C r}$ & $\mathbf{K}$ & $\mathbf{N a}$ & $\mathbf{N i}$ & $\mathbf{P}$ & $\mathbf{P b}$ & $\mathbf{S}$ & $\mathbf{S i}$ & $\overline{Z n}$ \\
\hline \multirow{5}{*}{1} & \multirow{5}{*}{0.377} & 1 & $<1.00 \mathrm{E}-01$ & $1.84 \mathrm{E}+00$ & $<1.00 \mathrm{E}+00$ & $1.28 \mathrm{E}+01$ & $<1.00 \mathrm{E}-01$ & $<1.00 \mathrm{E}-01$ & $4.39 \mathrm{E}+01$ & $<1.00 \mathrm{E}-01$ & $<1.00 \mathrm{E}+00$ & $<1.00 \mathrm{E}-01$ & $6.89 \mathrm{E}+01$ & $7.17 \mathrm{E}+00$ & $<1.00 \mathrm{E}-01$ \\
\hline & & 2 & $<1.00 \mathrm{E}-01$ & $1.93 \mathrm{E}+00$ & $<1.00 \mathrm{E}+00$ & $1.30 \mathrm{E}+01$ & $<1.00 \mathrm{E}-01$ & $<1.00 \mathrm{E}-01$ & $4.45 \mathrm{E}+01$ & $<1.00 \mathrm{E}-01$ & $<1.00 \mathrm{E}+00$ & $<1.00 \mathrm{E}-01$ & $7.32 \mathrm{E}+01$ & $7.47 \mathrm{E}+00$ & $<1.00 \mathrm{E}-01$ \\
\hline & & Average & $<1.00 \mathrm{E}-01$ & $1.89 \mathrm{E}+00$ & $<1.00 \mathrm{E}+00$ & 12.9 & $<1.00 \mathrm{E}-01$ & $<1.00 \mathrm{E}-01$ & 44.2 & $<1.00 \mathrm{E}-01$ & $<1.00 \mathrm{E}+00$ & $<1.00 \mathrm{E}-01$ & 71.1 & 7.32 & $<1.00 \mathrm{E}-01$ \\
\hline & & $\begin{array}{c}\text { Standard } \\
\text { Deviation }\end{array}$ & na & $6.36 \mathrm{E}-02$ & na & $1.41 \mathrm{E}-01$ & na & na & 4.24E-01 & na & na & na & $3.04 \mathrm{E}+00$ & $2.12 \mathrm{E}-01$ & na \\
\hline & & \%RSD & na & $3.38 \%$ & na & $1.10 \%$ & na & na & $0.96 \%$ & na & na & na & $4.28 \%$ & $2.90 \%$ & na \\
\hline \multirow{5}{*}{2} & \multirow{5}{*}{0.372} & 1 & $<1.00 \mathrm{E}-01$ & $3.39 \mathrm{E}+01$ & $<1.00 \mathrm{E}+00$ & $2.42 \mathrm{E}+01$ & $<1.00 \mathrm{E}-01$ & $<1.00 \mathrm{E}-01$ & $6.92 \mathrm{E}+01$ & $<1.00 \mathrm{E}-01$ & $<1.00 \mathrm{E}+00$ & $<1.00 \mathrm{E}-01$ & $5.72 \mathrm{E}+01$ & $1.25 \mathrm{E}+01$ & $<1.00 \mathrm{E}-01$ \\
\hline & & 2 & $<1.00 \mathrm{E}-01$ & $3.37 \mathrm{E}+01$ & $<1.00 \mathrm{E}+00$ & $2.44 \mathrm{E}+01$ & $<1.00 \mathrm{E}-01$ & $<1.00 \mathrm{E}-01$ & $6.93 \mathrm{E}+01$ & $<1.00 \mathrm{E}-01$ & $<1.00 \mathrm{E}+00$ & $<1.00 \mathrm{E}-01$ & $5.63 \mathrm{E}+01$ & $1.26 \mathrm{E}+01$ & $<1.00 \mathrm{E}-01$ \\
\hline & & Average & $<1.00 \mathrm{E}-01$ & $3.38 \mathrm{E}+01$ & $<1.00 \mathrm{E}+00$ & $2.43 \mathrm{E}+01$ & $<1.00 \mathrm{E}-01$ & $<1.00 \mathrm{E}-01$ & $6.93 \mathrm{E}+01$ & $<1.00 \mathrm{E}-01$ & $<1.00 \mathrm{E}+00$ & $<1.00 \mathrm{E}-01$ & $5.68 \mathrm{E}+01$ & $1.26 \mathrm{E}+01$ & $<1.00 \mathrm{E}-01$ \\
\hline & & $\begin{array}{c}\text { Standard } \\
\text { Deviation }\end{array}$ & na & $1.41 \mathrm{E}-01$ & na & $1.41 \mathrm{E}-01$ & na & na & 7.07E-02 & na & na & na & $6.36 \mathrm{E}-01$ & 7.07E-02 & na \\
\hline & & $\%$ RSD & na & $0.42 \%$ & na & $0.58 \%$ & na & na & $0.10 \%$ & na & na & na & $1.12 \%$ & $0.56 \%$ & na \\
\hline
\end{tabular}

Table E 5. SIM A DMR CONDENSATE COMPOSITE FILTRATE ICPES Ag-Zn

\begin{tabular}{|c|c|c|c|c|c|c|c|c|c|c|c|c|c|c|}
\hline \multirow{2}{*}{ Run } & $\mathbf{L}$ & \multicolumn{13}{|c|}{ Elemental Concentration $(\mathrm{mg} / \mathrm{L})$} \\
\hline & Vol & $\mathbf{A g}$ & $\mathbf{A l}$ & As & B & $\mathrm{Cr}$ & $\mathbf{K}$ & $\mathrm{Na}$ & $\mathrm{Ni}$ & $\mathbf{P}$ & $\mathbf{P b}$ & $\mathbf{S}$ & $\mathrm{Si}$ & $\mathrm{Zn}$ \\
\hline Composite & 0.749 & $<1.00 \mathrm{E}-01$ & $1.77 \mathrm{E}+01$ & $<1.00 \mathrm{E}+00$ & $1.86 \mathrm{E}+01$ & $<1.00 \mathrm{E}-01$ & $<1.00 \mathrm{E}-01$ & $5.66 \mathrm{E}+01$ & $<1.00 \mathrm{E}-01$ & $<1.00 \mathrm{E}+00$ & $<1.00 \mathrm{E}-01$ & $6.39 \mathrm{E}+01$ & $9.92 \mathrm{E}+00$ & $<1.00 \mathrm{E}-01$ \\
\hline
\end{tabular}


The DMR condensate filtrate anion or IC concentrations from the two runs for Simulant A module are shown in Table E 6. The DMR condensate filtrates can be represented as one volume of $0.749 \mathrm{~L}$ with composite concentrations based on the individual run averages times the volume per run. For example, the fluoride composite concentration in $\mathrm{ug} / \mathrm{L}$ is calculated as:

$$
c f_{F}=\frac{(0.377 * 4.58 E+05)+(0.372 * 8.49 E+05)}{0.377+0.372}=\frac{4.89 E+05}{0.749}=6.52 E+05
$$

The anion or IC concentrations based on this method for the DMR Condensate Composite Filtrate are shown in Table E 7 and these values are used in the mass balance.

Table E 6. SIM A DMR CONDENSATE FILTRATES IC F-PO

\begin{tabular}{|c|c|c|c|c|c|c|c|c|}
\hline \multirow{2}{*}{ Run } & $\mathbf{L}$ & \multirow{2}{*}{ Sample } & $u g / L$ & ug/L & ug/L & ug/L & $u g / L$ & ug/L \\
\hline & Volume & & F & Cl & $\mathrm{NO}_{2}$ & $\mathrm{NO}_{3}$ & $\mathrm{SO}_{4}$ & $\mathrm{PO}_{4}$ \\
\hline \multirow{5}{*}{1} & \multirow{5}{*}{0.377} & 1 & $4.61 \mathrm{E}+05$ & $1.10 \mathrm{E}+05$ & $3.90 \mathrm{E}+05$ & $<1.00 \mathrm{E}+05$ & $<1.00 . \mathrm{E}+05$ & $<1.00 . \mathrm{E}+05$ \\
\hline & & 2 & $4.55 \mathrm{E}+05$ & $1.08 \mathrm{E}+05$ & $3.83 \mathrm{E}+05$ & $<1.00 \mathrm{E}+05$ & $<1.00 . \mathrm{E}+05$ & $<1.00 . \mathrm{E}+05$ \\
\hline & & Average & $4.58 \mathrm{E}+05$ & $1.09 \mathrm{E}+05$ & $3.87 \mathrm{E}+05$ & $<1.00 \mathrm{E}+05$ & $<1.00 \mathrm{E}+05$ & $<1.00 \mathrm{E}+05$ \\
\hline & & Standard Deviation & $4.24 \mathrm{E}+03$ & $1.41 \mathrm{E}+03$ & $4.95 \mathrm{E}+03$ & na & na & na \\
\hline & & $\%$ RSD & $0.93 \%$ & $1.30 \%$ & $1.28 \%$ & na & $\mathrm{na}$ & $\mathrm{na}$ \\
\hline \multirow{5}{*}{2} & \multirow{5}{*}{0.372} & 1 & $8.38 \mathrm{E}+05$ & $3.35 \mathrm{E}+05$ & $1.46 \mathrm{E}+06$ & $1.67 \mathrm{E}+05$ & $<1.00 . \mathrm{E}+05$ & $<1.00 . \mathrm{E}+05$ \\
\hline & & 2 & $8.60 \mathrm{E}+05$ & $3.40 \mathrm{E}+05$ & $1.45 \mathrm{E}+06$ & $1.70 \mathrm{E}+05$ & $<1.00 . \mathrm{E}+05$ & $<1.00 . \mathrm{E}+05$ \\
\hline & & Average & $8.49 \mathrm{E}+05$ & $3.38 \mathrm{E}+05$ & $1.46 \mathrm{E}+06$ & $1.69 \mathrm{E}+05$ & $<1.00 . \mathrm{E}+05$ & $<1.00 . \mathrm{E}+05$ \\
\hline & & Standard Deviation & $1.56 \mathrm{E}+04$ & $3.54 \mathrm{E}+03$ & $7.07 \mathrm{E}+03$ & $2.12 \mathrm{E}+03$ & na & na \\
\hline & & $\%$ RSD & $1.83 \%$ & $1.05 \%$ & $0.49 \%$ & $1.26 \%$ & na & na \\
\hline
\end{tabular}

Table E 7. SIM A DMR CONDENSATE COMPOSITE FILTRATE IC F-PO

\begin{tabular}{|c|c|c|c|c|c|c|c|}
\hline \multirow{2}{*}{ Run } & $\mathbf{L}$ & $\mathbf{u g} / \mathbf{L}$ & $\mathbf{u g} / \mathbf{L}$ & $\mathbf{u g} / \mathbf{L}$ & $\mathbf{u g} / \mathbf{L}$ & $\mathbf{u g} / \mathbf{L}$ & $\mathbf{u g} / \mathbf{L}$ \\
\cline { 2 - 8 } & Volume & $\mathbf{F}$ & $\mathbf{C l}$ & $\mathbf{N O}_{2}$ & $\mathbf{N O}_{3}$ & $\mathbf{S O}_{4}$ & $\mathbf{P O}_{4}$ \\
\hline Composite & 0.749 & $6.52 \mathrm{E}+05$ & $2.22 \mathrm{E}+05$ & $9.17 \mathrm{E}+05$ & $<1.34 . \mathrm{E}+05$ & $<1.00 . \mathrm{E}+05$ & $<1.00 . \mathrm{E}+05$ \\
\hline
\end{tabular}

The DMR condensate filtrate trace elemental or ICPMS concentrations from the two runs for Simulant A module are shown in Table E- 8 . The DMR condensate filtrates can be represented as one volume of 0.749 $\mathrm{L}$ with composite concentrations based on the individual run averages times the volume per run. For example, the cesium composite concentration in $\mathrm{ug} / \mathrm{L}$ is calculated as:

$$
c f_{C s}=\frac{0.377 * 1.53 E 04+0.372 * 2.45 E 04}{0.377+0.372}=\frac{4.89 E 05}{0.749}=1.99 E 04
$$

The trace elemental or ICPMS concentrations based on this method for the DMR condensate composite filtrate are shown in Table E 9 and these values are used in the mass balance. 
Table E 8. SIM A DMR CONDENSATE FILTRATES ICPMS Cs, Re, I

\begin{tabular}{|c|c|c|c|c|}
\hline \multirow{2}{*}{ Run } & $\mathbf{L}$ & $\mathbf{u g} / \mathbf{L}$ & $\mathbf{u g} / \mathbf{L}$ & $\mathbf{u g} / \mathbf{L}$ \\
\cline { 2 - 5 } & Volume & $\mathbf{C s}$ & $\mathbf{R e}$ & $\mathbf{I}$ \\
\hline 1 & 0.377 & $1.53 \mathrm{E}+04$ & $7.71 \mathrm{E}+03$ & $1.19 \mathrm{E}+04$ \\
\hline 2 & 0.372 & $2.45 \mathrm{E}+04$ & $1.38 \mathrm{E}+04$ & $1.69 \mathrm{E}+04$ \\
\hline
\end{tabular}

Table E 9. SIM A DMR CONDENSATE COMPOSITE FILTRATE ICPMS Cs, Re, I

\begin{tabular}{|c|c|c|c|c|}
\hline \multirow{2}{*}{ Run } & $\mathbf{L}$ & $\mathbf{u g} / \mathbf{L}$ & $\mathbf{u g} / \mathbf{L}$ & $\mathbf{u g} / \mathbf{L}$ \\
\cline { 2 - 5 } & Volume & Cs & $\mathbf{R e}$ & I \\
\hline Composite & 0.749 & $1.99 \mathrm{E}+04$ & $1.07 \mathrm{E}+04$ & $1.44 \mathrm{E}+04$ \\
\hline
\end{tabular}

The DMR condensate filtered solids concentrations from the two runs for Simulant A module are shown in Table E 10. The DMR condensate filtered solids can be represented as one mass of $0.01532 \mathrm{~g}$ with composite concentrations based on the individual run values times the mass per run. For example, the aluminum composite concentration in $\mathrm{wt} \%$ is calculated as:

$$
C S_{A l}=\frac{0.00733 * 77.06 \%+0.00799 * 67.62 \%}{0.00733+0.00799}=\frac{0.01105}{0.01532}=72.14 \%
$$

The cation or ICPES concentrations based on this method for the DMR condensate composite filtered solids are shown in Table E 11 and these values are used in the mass balance. 


\section{Table E 10. SIM A DMR CONDENSATE FILTERED SOLIDS ICPES Ag-Zn}

\begin{tabular}{|c|c|c|c|c|c|c|c|c|c|c|c|c|c|}
\hline \multirow{2}{*}{ Run } & g & wt\% & wt\% & wt $\%$ & wt\% & $w t \%$ & $w t \%$ & wt \% & $w t \%$ & wt\% & wt\% & wt\% & wt $\%$ \\
\hline & Mass & $\mathbf{A g}$ & $\overline{\mathrm{Al}}$ & B & $\mathrm{Cr}$ & $\bar{K}$ & $\mathbf{N a}$ & $\mathbf{N i}$ & $\mathbf{P}$ & $\mathbf{P b}$ & S & $\mathbf{S i}$ & $\mathbf{Z n}$ \\
\hline 1 & 0.00733 & $<0.04$ & 77.06 & 0.15 & 0.17 & $<0.54$ & 5.92 & $<0.03$ & 0.38 & $<0.11$ & 1.72 & 0.75 & 0.74 \\
\hline 2 & 0.00799 & $<0.04$ & 67.62 & 0.23 & 0.29 & $<0.50$ & 7.83 & 0.05 & 0.54 & 0.20 & 2.97 & 1.53 & 0.61 \\
\hline
\end{tabular}

Table E 11. SIM A DMR CONDENSATE COMPOSITE FILTERED SOLIDS ICPES Ag-Zn

\begin{tabular}{|c|c|c|c|c|c|c|c|c|c|c|c|c|c|}
\hline \multirow{2}{*}{ Run } & g & wt\% & wt\% & wt\% & wt\% & wt\% & wt\% & wt \% & wt\% & wt\% & wt\% & wt\% & wt $\%$ \\
\hline & Mass & Ag & Al & B & $\mathrm{Cr}$ & $\mathbf{K}$ & $\mathrm{Na}$ & $\mathrm{Ni}$ & $\mathbf{P}$ & $\mathbf{P b}$ & $\mathbf{S}$ & $\mathbf{S i}$ & $\mathbf{Z n}$ \\
\hline Composite & 0.01532 & $<0.04$ & 72.14 & 0.19 & 0.23 & $<0.52$ & 6.91 & 0.04 & 0.47 & 0.16 & 2.37 & 1.16 & 0.67 \\
\hline
\end{tabular}


Anion or IC analyses were not performed on the Simulant A samples, but the $\mathrm{SO}_{4}$ and $\mathrm{PO}_{4}$ concentrations can be estimated from the $\mathrm{S}$ and $\mathrm{P}$ analyses using the following logic:

$$
\begin{aligned}
& c S_{S O 4}=\frac{c S_{S} * M W_{S O 4}}{M W_{S}} \\
& C S_{P O 4}=\frac{c S_{S} * M W_{P O 4}}{M W_{P}}
\end{aligned}
$$

As an example, the $\mathrm{SO}_{4}$ and $\mathrm{PO}_{4}$ concentrations for the DMR Condensate Filtered Solids for the first run Simulant A can be calculated as follows:

$$
\begin{gathered}
C S_{S O 4}=\frac{1.72 \% * 96.0636}{32.0660}=5.15 \% \\
C S_{P O 4}=\frac{0.3832 \% * 94.9714}{30.9738}=1.18 \%
\end{gathered}
$$

Using this logic, the $\mathrm{SO}_{4}$ and $\mathrm{PO}_{4}$ concentrations for the DMR Condensate Filtered Solids are shown in Table E 12. Using the same logic shown earlier, the two runs of DMR condensate filtered solids data can be represented as one mass of $0.01532 \mathrm{~g}$ with composite concentrations. These composite concentrations are shown in Table E 13 and are used in the mass balance.

Table E 12. SIM A DMR CONDENSATE FILTERED SOLIDS IC SO $\mathrm{SO}_{4}-\mathrm{PO}_{4}$

\begin{tabular}{|c|c|c|c|}
\hline \multirow{2}{*}{ Run } & $\mathbf{g}$ & $\mathbf{w t} \%$ & $\mathbf{w t} \%$ \\
\cline { 2 - 4 } & $\mathbf{M a s s}$ & $\mathbf{S O}_{\mathbf{4}}$ & $\mathbf{P O}_{\mathbf{4}}$ \\
\hline 1 & 0.00733 & 5.15 & 1.18 \\
\hline 2 & 0.00799 & 8.91 & 1.67 \\
\hline
\end{tabular}

Table E 13. SIM A DMR CONDENSATE COMPOSITE FILTERED SOLIDS IC SO $\mathrm{SO}_{4}-\mathrm{PO}_{4}$

\begin{tabular}{|c|c|c|c|}
\hline \multirow{2}{*}{ Run } & g & wt\% & wt\% \\
\cline { 2 - 4 } & Mass & $\mathbf{S O}_{4}$ & $\mathbf{P O}_{4}$ \\
\hline Composite & 0.01532 & 7.11 & 1.43 \\
\hline
\end{tabular}

The DMR condensate filtered solids trace elemental or ICPMS concentrations from the two runs for Simulant A module are shown in Table E 14. Using the same logic shown earlier, the two runs of DMR condensate filtered solids data can be represented as one mass of $0.01532 \mathrm{~g}$ with composite concentrations. These composite concentrations are shown in Table E-15 and are used in the mass balance.

Table E 14. SIM A DMR CONDENSATE FILTERED SOLIDS ICPMS Cs, Re, I

\begin{tabular}{|c|c|c|c|c|}
\hline \multirow{2}{*}{ Run } & g & wt\% & wt\% & wt\% \\
\cline { 2 - 5 } & Mass & Cs & Re & I \\
\hline 1 & 0.00733 & 2.36 & 0.16 & 0.08 \\
\hline 2 & 0.00799 & 3.90 & 0.61 & 0.39 \\
\hline
\end{tabular}


Table E 15. SIM A DMR CONDENSATE COMPOSITE FILTERED SOLIDS ICPMS Cs, Re, I

\begin{tabular}{|c|c|c|c|c|}
\hline \multirow{2}{*}{ Run } & g & wt\% & wt\% & wt\% \\
\cline { 2 - 5 } & Mass & Cs & Re & I \\
\hline Composite & 0.01532 & 3.16 & 0.40 & 0.24 \\
\hline
\end{tabular}

The crossbar rinse filtrate cation or ICPES concentrations from the two runs for Simulant A module are shown in Table E 16. The DMR condensate filtrates can be represented as one volume of $0.1408 \mathrm{~L}$ with composite concentrations based on the individual run averages times the volume per run. For example, the aluminum composite concentration in $\mathrm{mg} / \mathrm{L}$ is calculated as:

$$
x f_{A l}=\frac{(0.0705 * 9.34 E+01)+(0.0703 * 4.65 E+01)}{0.0705+0.0703}=\frac{9.85 E+00}{0.1408}=7.00 E+01
$$

The cation or ICPES concentrations based on this method for the crossbar rinse composite filtrate are shown in Table E 17 and these values are used in the mass balance. 
Table E 16. SIM A CROSSBAR RINSE FILTRATES ICPES Ag-Zn

\begin{tabular}{|c|c|c|c|c|c|c|c|c|c|c|c|c|c|c|c|}
\hline \multirow{2}{*}{ Run } & \multirow{2}{*}{$\begin{array}{c}\text { L } \\
\text { Volume }\end{array}$} & \multirow{2}{*}{ Sample } & \multicolumn{13}{|c|}{ Elemental Concentration $(\mathrm{mg} / \mathrm{L})$} \\
\hline & & & $\mathbf{A g}$ & $\mathbf{A l}$ & As & $\mathbf{B}$ & $\mathrm{Cr}$ & $\mathbf{K}$ & $\mathbf{N a}$ & $\mathrm{Ni}$ & $\mathbf{P}$ & $\mathbf{P b}$ & $\mathbf{S}$ & $\mathbf{S i}$ & $\mathbf{Z n}$ \\
\hline \multirow{5}{*}{1} & \multirow{5}{*}{0.0705} & 1 & $<1.00 \mathrm{E}-01$ & $9.30 \mathrm{E}+01$ & $<1.00 \mathrm{E}+00$ & $1.13 \mathrm{E}+01$ & $5.32 \mathrm{E}-01$ & $4.75 \mathrm{E}-01$ & $8.25 \mathrm{E}+01$ & $<1.00 \mathrm{E}-01$ & $<1.00 \mathrm{E}+00$ & $<1.00 \mathrm{E}-01$ & $5.68 \mathrm{E}+00$ & $3.05 \mathrm{E}+02$ & $4.41 \mathrm{E}-01$ \\
\hline & & 2 & $<<1.00 \mathrm{E}-01$ & $9.38 \mathrm{E}+01$ & $<1.00 \mathrm{E}+00$ & $1.16 \mathrm{E}+01$ & $5.24 \mathrm{E}-01$ & $4.77 \mathrm{E}-01$ & $8.26 \mathrm{E}+01$ & $<1.00 \mathrm{E}-01$ & $<1.00 \mathrm{E}+00$ & $<<1.00 \mathrm{E}-01$ & $4.89 \mathrm{E}+00$ & $3.07 \mathrm{E}+02$ & $4.31 \mathrm{E}-01$ \\
\hline & & Average & $<1.00 \mathrm{E}-01$ & $9.34 \mathrm{E}+01$ & $<1.00 \mathrm{E}+00$ & $1.15 \mathrm{E}+01$ & $5.28 \mathrm{E}-01$ & $4.76 \mathrm{E}-01$ & $8.26 \mathrm{E}+01$ & $<1.00 \mathrm{E}-01$ & $<1.00 \mathrm{E}+00$ & $<1.00 \mathrm{E}-01$ & $5.29 \mathrm{E}+00$ & $3.06 \mathrm{E}+02$ & $4.36 \mathrm{E}-01$ \\
\hline & & $\begin{array}{c}\text { Std. } \\
\text { Dev. }\end{array}$ & na & $5.66 \mathrm{E}-01$ & na & $2.12 \mathrm{E}-01$ & $5.66 \mathrm{E}-03$ & $1.41 \mathrm{E}-03$ & 7.07E-02 & na & na & na & $5.59 \mathrm{E}-01$ & $1.41 \mathrm{E}+00$ & $7.07 \mathrm{E}-03$ \\
\hline & & $\%$ RSD & na & $0.61 \%$ & na & $1.85 \%$ & $1.07 \%$ & $0.30 \%$ & $0.09 \%$ & na & na & na & $10.57 \%$ & $0.46 \%$ & $1.62 \%$ \\
\hline \multirow{5}{*}{2} & \multirow{5}{*}{0.0703} & 1 & $<1.00 \mathrm{E}-01$ & $4.65 \mathrm{E}+01$ & $<1.00 \mathrm{E}+00$ & $2.12 \mathrm{E}+01$ & $3.80 \mathrm{E}-01$ & $<1.00 \mathrm{E}-01$ & $3.80 \mathrm{E}+01$ & $<1.00 \mathrm{E}-01$ & $<1.00 \mathrm{E}+00$ & $<1.00 \mathrm{E}-01$ & $5.65 \mathrm{E}+00$ & $4.48 \mathrm{E}+02$ & $1.93 \mathrm{E}-01$ \\
\hline & & 2 & $<1.00 \mathrm{E}-01$ & $4.65 \mathrm{E}+01$ & $<1.00 \mathrm{E}+00$ & $2.11 \mathrm{E}+01$ & $4.05 \mathrm{E}-01$ & $<1.00 \mathrm{E}-01$ & $3.79 \mathrm{E}+01$ & $<1.00 \mathrm{E}-01$ & $<1.00 \mathrm{E}+00$ & $<1.00 \mathrm{E}-01$ & $6.40 \mathrm{E}+00$ & $4.49 \mathrm{E}+02$ & $1.84 \mathrm{E}-01$ \\
\hline & & Average & $<1.00 \mathrm{E}-01$ & $4.65 \mathrm{E}+01$ & $<1.00 \mathrm{E}+00$ & $2.12 \mathrm{E}+01$ & $3.93 \mathrm{E}-01$ & $<1.00 \mathrm{E}-01$ & $3.80 \mathrm{E}+01$ & $<1.00 \mathrm{E}-01$ & $<1.00 \mathrm{E}+00$ & $<1.00 \mathrm{E}-01$ & $6.03 \mathrm{E}+00$ & $4.49 \mathrm{E}+02$ & $1.89 \mathrm{E}-01$ \\
\hline & & $\begin{array}{l}\text { Std. } \\
\text { Dev. }\end{array}$ & na & $0.00 \mathrm{E}+00$ & na & 7.07E-02 & $1.77 \mathrm{E}-02$ & na & 7.07E-02 & na & na & na & $5.30 \mathrm{E}-01$ & $7.07 \mathrm{E}-01$ & $6.36 \mathrm{E}-03$ \\
\hline & & \%RSD & na & $0.00 \%$ & na & $0.33 \%$ & $4.50 \%$ & na & $0.19 \%$ & na & na & na & $8.80 \%$ & $0.16 \%$ & $3.38 \%$ \\
\hline
\end{tabular}

Table E 17. SIM A CROSSBAR RINSE COMPOSITE FILTRATE ICPES Ag-Zn

\begin{tabular}{|c|c|c|c|c|c|c|c|c|c|c|c|c|c|c|}
\hline \multirow{2}{*}{ Run } & $\mathbf{L}$ & $\mathrm{mg} / \mathrm{L}$ & $\mathrm{mg} / \mathrm{L}$ & $\mathrm{mg} / \mathrm{L}$ & $\mathrm{mg} / \mathrm{L}$ & $\mathrm{mg} / \mathrm{L}$ & $\mathrm{mg} / \mathrm{L}$ & $\mathrm{mg} / \mathrm{L}$ & $\mathrm{mg} / \mathrm{L}$ & $\mathrm{mg} / \mathrm{L}$ & $\mathrm{mg} / \mathrm{L}$ & $\mathrm{mg} / \mathrm{L}$ & $\mathrm{mg} / \mathrm{L}$ & $\mathrm{mg} / \mathrm{L}$ \\
\hline & Volume & $\mathrm{Ag}$ & Al & As & B & $\mathrm{Cr}$ & $\mathbf{K}$ & $\mathrm{Na}$ & $\mathrm{Ni}$ & $\mathbf{P}$ & $\mathbf{P b}$ & $\mathbf{S}$ & $\mathbf{S i}$ & $\overline{Z n}$ \\
\hline Composite & 0.1408 & $<1.00 \mathrm{E}-01$ & $7.00 \mathrm{E}+01$ & $<1.00 \mathrm{E}+00$ & $1.63 \mathrm{E}+01$ & $4.60 \mathrm{E}-01$ & $2.88 \mathrm{E}-01$ & $6.03 \mathrm{E}+01$ & $<1.00 \mathrm{E}-01$ & $<1.00 \mathrm{E}+00$ & $<1.00 \mathrm{E}-01$ & $5.65 \mathrm{E}+00$ & $3.77 \mathrm{E}+02$ & $3.12 \mathrm{E}-01$ \\
\hline
\end{tabular}


The crossbar rinse filtrate anion or IC concentrations from the two runs for Simulant A module are shown in Table E 18. The DMR condensate filtrates can be represented as one volume of $0.1408 \mathrm{~L}$ with composite concentrations based on the individual run averages times the volume per run. For example, the fluoride composite concentration in $\mathrm{ug} / \mathrm{L}$ is calculated as:

$$
x f_{F}=\frac{0.0705 * 2.48 E 06+0.0703 * 2.99 E 06}{0.0705+0.0703}=\frac{3.85 E 05}{0.1408}=2.73 E 06
$$

The anion or IC concentrations based on this method for the crossbar rinse composite filtrate are shown in Table E 19 and these values are used in the mass balance.

Table E 18. SIM A CROSSBAR RINSE FILTRATES IC F-PO

\begin{tabular}{|c|c|c|c|c|c|c|c|c|}
\hline \multirow{2}{*}{ Run } & $\mathbf{L}$ & \multirow{2}{*}{ Sample } & ug/L & ug/L & ug/L & ug/L & ug/L & ug/L \\
\hline & Volume & & $\mathbf{F}$ & $\mathrm{Cl}$ & $\mathrm{NO}_{2}$ & $\mathrm{NO}_{3}$ & $\mathbf{S O}_{4}$ & $\mathbf{P O}_{4}$ \\
\hline \multirow{5}{*}{1} & \multirow{5}{*}{0.0705} & 1 & $2.43 \mathrm{E}+06$ & $1.95 \mathrm{E}+05$ & $<1.00 \mathrm{E}+05$ & $<1.00 \mathrm{E}+05$ & $1.22 \mathrm{E}+05$ & $<1.00 \mathrm{E}+05$ \\
\hline & & 2 & $2.53 \mathrm{E}+06$ & $1.90 \mathrm{E}+05$ & $<1.00 \mathrm{E}+05$ & $<1.00 \mathrm{E}+05$ & $<1.00 \mathrm{E}+05$ & $<1.00 \mathrm{E}+05$ \\
\hline & & Average & $2.48 \mathrm{E}+06$ & $1.93 \mathrm{E}+05$ & $<1.00 \mathrm{E}+05$ & $<1.00 \mathrm{E}+05$ & $1.22 \mathrm{E}+05$ & $<1.00 \mathrm{E}+05$ \\
\hline & & Std Dev. & $7.07 \mathrm{E}+04$ & $3.54 \mathrm{E}+03$ & na & na & 0.00 & na \\
\hline & & $\%$ RSD & $2.85 \%$ & $1.84 \%$ & na & na & $0.00 \%$ & na \\
\hline \multirow{5}{*}{2} & \multirow{5}{*}{0.0703} & 1 & $2.98 \mathrm{E}+06$ & $5.46 \mathrm{E}+05$ & $<1.00 \mathrm{E}+05$ & $<1.00 \mathrm{E}+05$ & $1.05 \mathrm{E}+05$ & $<1.00 \mathrm{E}+05$ \\
\hline & & 2 & $3.00 \mathrm{E}+06$ & $5.51 \mathrm{E}+05$ & $<1.00 \mathrm{E}+05$ & $<1.00 \mathrm{E}+05$ & $1.07 \mathrm{E}+05$ & $<1.00 \mathrm{E}+05$ \\
\hline & & Average & $2.99 \mathrm{E}+06$ & $5.49 \mathrm{E}+05$ & $<1.00 \mathrm{E}+05$ & $<1.00 \mathrm{E}+05$ & $1.06 \mathrm{E}+05$ & $<1.00 \mathrm{E}+05$ \\
\hline & & Std Dev. & $1.41 \mathrm{E}+04$ & $3.54 \mathrm{E}+03$ & na & na & $1.41 \mathrm{E}+03$ & na \\
\hline & & $\%$ RSD & $0.47 \%$ & $0.64 \%$ & na & na & $1.33 \%$ & na \\
\hline
\end{tabular}

Table E 19. SIM A CROSSBAR RINSE COMPOSITE FILTRATE IC F-PO

\begin{tabular}{|c|c|c|c|c|c|c|c|}
\hline \multirow{2}{*}{ Run } & $\mathbf{L}$ & $\mathbf{u g} / \mathbf{L}$ & $\mathbf{u g} / \mathbf{L}$ & $\mathbf{u g} / \mathbf{L}$ & $\mathbf{u g} / \mathbf{L}$ & $\mathbf{u g} / \mathbf{L}$ & $\mathbf{u g} / \mathbf{L}$ \\
\cline { 2 - 8 } & Volume & $\mathbf{F}$ & $\mathbf{C l}$ & $\mathbf{N O}_{\mathbf{2}}$ & $\mathbf{N O}_{3}$ & $\mathbf{S O}_{4}$ & $\mathbf{P O}_{4}$ \\
\hline Composite & 0.1408 & $2.73 \mathrm{E}+06$ & $3.70 \mathrm{E}+05$ & $<1.00 . \mathrm{E}+05$ & $<1.00 . \mathrm{E}+05$ & $1.14 \mathrm{E}+05$ & $<1.00 . \mathrm{E}+05$ \\
\hline
\end{tabular}

The crossbar rinse filtrate trace elemental or ICPMS concentrations from the two runs for Simulant A module are shown in Table E 20. The DMR condensate filtrates can be represented as one volume of $0.1408 \mathrm{~L}$ with composite concentrations based on the individual run averages times the volume per run. For example, the cesium composite concentration in $\mathrm{ug} / \mathrm{L}$ is calculated as:

$$
x f_{C S}=\frac{(0.0705 * 4.35 E+03)+(0.0703 * 6.34 E+03)}{0.0705+0.0703}=\frac{7.52 E+02}{0.1408}=5.34 E+03
$$

The trace elemental or ICPMS concentrations based on this method for the DMR condensate composite filtrate are shown in Table E 21 and these values are used in the mass balance.

Table E 20. SIM A CROSSBAR RINSE FILTRATES ICPMS Cs, Re, I

\begin{tabular}{|c|c|c|c|c|}
\hline \multirow{2}{*}{ Run } & $\mathbf{L}$ & $\mathbf{u g} / \mathbf{L}$ & $\mathbf{u g} / \mathbf{L}$ & $\mathbf{u g} / \mathbf{L}$ \\
\cline { 2 - 5 } & Volume & $\mathbf{C s}$ & $\mathbf{R e}$ & $\mathbf{I}$ \\
\hline 1 & 0.0705 & $4.35 \mathrm{E}+03$ & $7.60 \mathrm{E}+02$ & $3.12 \mathrm{E}+03$ \\
\hline 2 & 0.0703 & $6.34 \mathrm{E}+03$ & $2.40 \mathrm{E}+03$ & $1.34 \mathrm{E}+04$ \\
\hline
\end{tabular}


Table E 21. SIM A CROSSBAR RINSE COMPOSITE FILTRATE ICPMS Cs, Re, I

\begin{tabular}{|c|c|c|c|c|}
\hline \multirow{2}{*}{ Run } & $\mathbf{L}$ & $\mathbf{u g} / \mathbf{L}$ & $\mathbf{u g} / \mathbf{L}$ & $\mathbf{u g} / \mathbf{L}$ \\
\cline { 2 - 5 } & Volume & $\mathbf{C s}$ & $\mathbf{R e}$ & $\mathbf{I}$ \\
\hline Composite & 0.1408 & $5.34 \mathrm{E}+02$ & $1.58 \mathrm{E}+03$ & $8.27 \mathrm{E}+03$ \\
\hline
\end{tabular}

The crossbar rinse filtered solids concentrations from the two runs for Simulant A module are shown in Table E 22 . The crossbar rinse filtered solids can be represented as one mass of $0.00578 \mathrm{~g}$ with composite concentrations based on the individual run values times the mass per run. For example, the aluminum composite concentration in $\mathrm{wt} \%$ is calculated as:

$$
x s_{A l}=\frac{0.00291 * 30.27 \%+0.00287 * 30.45 \%}{0.00291+0.00287}=\frac{0.00175}{0.00578}=30.36 \%
$$

The cation or ICPES concentrations based on this method for the DMR condensate composite filtered solids are shown in Table E 23 and these values are used in the mass balance. 
Table E 22 . SIM A CROSSBAR RINSE FILTERED SOLIDS ICPES Ag-Zn

\begin{tabular}{|c|c|c|c|c|c|c|c|c|c|c|c|c|c|}
\hline \multirow{2}{*}{ Run } & g & wt $\%$ & $w t \%$ & wt $\%$ & wt $\%$ & wt $\%$ & wt $\%$ & wt $\%$ & $w t \%$ & $w t \%$ & wt $\%$ & $w t \%$ & $\mathrm{wt} \%$ \\
\hline & Mass & Ag & Al & B & $\mathrm{Cr}$ & $\mathbf{K}$ & $\mathrm{Na}$ & $\mathbf{N i}$ & $\mathbf{P}$ & $\mathbf{P b}$ & $\mathbf{S}$ & $\mathbf{S i}$ & $\mathrm{Zn}$ \\
\hline 1 & 0.00291 & $<0.10$ & 30.27 & $<0.12$ & 0.55 & $<1.36$ & 21.32 & 0.18 & 0.62 & 0.30 & 1.33 & 30.95 & 0.18 \\
\hline 2 & 0.00287 & $<0.11$ & 30.45 & $<0.12$ & 0.56 & $<1.38$ & 21.40 & 0.18 & 0.63 & $<0.29$ & 1.22 & 31.14 & 0.17 \\
\hline
\end{tabular}

Table E 23. SIM A CROSSBAR RINSE COMPOSITE FILTERED SOLIDS ICPES Ag-Zn

\begin{tabular}{|c|c|c|c|c|c|c|c|c|c|c|c|c|c|}
\hline \multirow{2}{*}{ Run } & g & wt\% & wt $\%$ & wt\% & wt $\%$ & wt $\%$ & wt\% & wt $\%$ & wt\% & wt\% & wt $\%$ & wt\% & wt $\%$ \\
\hline & Mass & Ag & Al & B & $\mathrm{Cr}$ & $\mathbf{K}$ & $\mathbf{N a}$ & $\mathbf{N i}$ & $\mathbf{P}$ & $\mathbf{P b}$ & $\mathbf{S}$ & $\mathbf{S i}$ & $\mathbf{Z n}$ \\
\hline Composite & 0.00578 & $<0.11$ & 30.36 & $<0.12$ & 0.55 & $<1.37$ & 21.36 & 0.18 & 0.63 & 0.15 & 1.27 & 31.05 & 0.17 \\
\hline
\end{tabular}


Anion or IC analyses were not performed on the SIM A samples but the $\mathrm{SO}_{4}$ and $\mathrm{PO}_{4}$ concentrations can be estimated from the $\mathrm{S}$ and $\mathrm{P}$ analyses using the following logic:

$$
\begin{aligned}
& x s_{S O 4}=\frac{x s_{S} * M W_{S O 4}}{M W_{S}} \\
& x s_{P O 4}=\frac{x s_{S} * M W_{P O 4}}{M W_{P}}
\end{aligned}
$$

As an example, the $\mathrm{SO}_{4}$ and $\mathrm{PO}_{4}$ concentrations for the crossbar rinse filtered solids for the first run Simulant A module can be calculated as follows:

$$
\begin{gathered}
x S_{S O 4}=\frac{1.33 \% * 96.0636}{32.0660}=3.98 \% \\
x S_{P O 4}=\frac{0.6243 \% * 94.9714}{30.9738}=1.91 \%
\end{gathered}
$$

Using this logic, the $\mathrm{SO}_{4}$ and $\mathrm{PO}_{4}$ concentrations for the crossbar rinse Filtered Solids are shown in Table E 24. Using the same logic shown earlier, the two runs of DMR condensate filtered solids data can be represented as one mass of $0.01532 \mathrm{~g}$ with composite concentrations. These composite concentrations are shown in Table E 25 and are used in the mass balance.

Table E 24. SIM A CROSSBAR RINSE FILTERED SOLIDS IC SO $\mathrm{S}_{4}-\mathrm{PO}_{4}$

\begin{tabular}{|c|c|c|c|}
\hline \multirow{2}{*}{ Run } & $\mathbf{g}$ & $\mathbf{w t} \%$ & $\mathbf{w t} \%$ \\
\cline { 2 - 4 } & Mass & $\mathbf{S O}_{\mathbf{4}}$ & $\mathbf{P O}_{\mathbf{4}}$ \\
\hline 1 & 0.00291 & 3.98 & 1.91 \\
\hline 2 & 0.00287 & 3.66 & 1.93 \\
\hline
\end{tabular}

Table E 25. SIM A CROSSBAR RINSE COMPOSITE FILTERED SOLIDS IC SO $4-\mathrm{PO}_{4}$

\begin{tabular}{|c|c|c|c|}
\hline \multirow{2}{*}{ Run } & g & wt\% & wt\% \\
\cline { 2 - 4 } & Mass & $\mathbf{S O}_{4}$ & $\mathbf{P O}_{4}$ \\
\hline Composite & 0.00578 & 3.82 & 1.92 \\
\hline
\end{tabular}

The crossbar rinse filtered solids trace elemental or ICPMS concentrations from the two runs for Simulant A module are shown in Table E 26. Using the same logic shown earlier, the two runs of DMR condensate filtered solids data can be represented as one mass of $0.00578 \mathrm{~g}$ with composite concentrations. These composite concentrations are shown in Table E-27 and are used in the mass balance.

Table E 26. SIM A CROSSBAR RINSE FILTERED SOLIDS ICPMS Cs, Re, I

\begin{tabular}{|c|c|c|c|c|}
\hline \multirow{2}{*}{ Run } & g & wt\% & wt\% & wt\% \\
\cline { 2 - 5 } & Mass & Cs & Re & I \\
\hline 1 & 0.00291 & 0.57 & 0.10 & 0.07 \\
\hline 2 & 0.00287 & 0.46 & 0.13 & 0.22 \\
\hline
\end{tabular}


SRNL-STI-2011-00331

Revision 0

Table E 27. SIM A CROSSBAR RINSE COMPOSITE FILTERED SOLIDS ICPMS Cs, Re, I

\begin{tabular}{|c|c|c|c|c|}
\hline \multirow{2}{*}{ Run } & g & wt\% & wt\% & wt\% \\
\cline { 2 - 5 } & Mass & Cs & Re & I \\
\hline Composite & 0.00578 & 0.52 & 0.12 & 0.15 \\
\hline
\end{tabular}




\section{Appendix F. Sample Analyses for REPEAT Simulant WTP SW BSR Campaign in Spring 2011}

Table F 1 through Table F 3 give the ICPES, IC, and ICPMS concentrations for the Repeat Simulant A granular product samples. The average concentrations are used in the mass balance.

Table F 1 . REPEAT SIM A GRANULAR PRODUCT ICPES Ag-Zn

\begin{tabular}{|c|c|c|c|c|c|c|c|c|c|c|c|c|c|}
\hline \multirow{2}{*}{ Sample } & \multicolumn{13}{|c|}{ Elemental Concentration (wt\%) } \\
\hline & Ag & Al & As & $\mathbf{B}$ & $\mathrm{Cr}$ & $\mathbf{K}$ & $\mathbf{N a}$ & $\mathbf{N i}$ & $\mathbf{P}$ & $\mathbf{P b}$ & $\mathbf{S}$ & Si & Zn \\
\hline 1 & $<0.0022$ & 17.30 & $<0.0018$ & 0.33 & 0.09 & 0.95 & 14.60 & 0.0032 & 0.085 & 0.0099 & 0.16 & 18.90 & 0.10 \\
\hline 2 & $<0.0021$ & 16.60 & $<0.0017$ & 0.30 & 0.09 & 0.90 & 14.10 & 0.0033 & 0.080 & 0.0075 & 0.16 & 19.30 & 0.09 \\
\hline 3 & $<0.0023$ & 17.50 & $<0.0018$ & 0.33 & 0.09 & 1.02 & 14.00 & 0.0034 & 0.086 & 0.0081 & 0.16 & 19.20 & 0.10 \\
\hline 4 & & 16.40 & & & & & & & & & & & 0.12 \\
\hline 5 & & 16.30 & & & & & & & & & | & & 0.12 \\
\hline 6 & & 16.70 & & & & & & & & & & & 0.12 \\
\hline Average & $<0.0022$ & 16.80 & $<0.0018$ & 0.33 & 0.09 & 0.96 & 14.23 & 0.00 & 0.084 & 0.0085 & 0.16 & 19.13 & 0.11 \\
\hline Std. Dev. & 0.0001 & 0.49 & 0.0001 & 0.01 & 0.00 & 0.06 & 0.32 & 0.00 & 0.00 & 0.00 & 0.00 & 0.21 & 0.01 \\
\hline$\%$ RSD & $4.40 \%$ & $2.92 \%$ & $4.51 \%$ & $3.94 \%$ & $2.52 \%$ & $6.22 \%$ & $2.26 \%$ & $3.67 \%$ & $3.75 \%$ & $14.96 \%$ & $1.66 \%$ & $1.09 \%$ & $11.09 \%$ \\
\hline
\end{tabular}

Table F 2. REPEAT SIM A GRANULAR PRODUCT IC F-PO

\begin{tabular}{|c|l|l|l|l|l|l|}
\hline \multirow{2}{*}{ Sample } & \multicolumn{1}{|c|}{$\mathbf{w t \%}$} & $\mathbf{w t} \%$ & $\mathbf{w t} \%$ & $\mathbf{w t} \%$ & $\mathbf{w t} \%$ & \multicolumn{1}{c|}{$\mathbf{w t} \%$} \\
\cline { 2 - 7 } & \multicolumn{1}{|c|}{$\mathbf{F}$} & $\mathbf{C l}$ & $\mathbf{N} \mathbf{O}_{\mathbf{2}}$ & $\mathbf{N O}_{\mathbf{3}}$ & $\mathbf{S O}_{\mathbf{4}}$ & \multicolumn{1}{|c|}{$\mathbf{P O}_{\mathbf{4}}$} \\
\hline 1 & 0.33 & 0.76 & $<0.12$ & $<0.12$ & 0.23 & 0.24 \\
\hline 2 & 0.34 & 0.74 & $<0.13$ & $<0.13$ & 0.15 & 0.24 \\
\hline Average & 0.31 & 0.72 & $<0.13$ & $<0.13$ & 0.17 & 0.24 \\
\hline Standard Deviation & 0.33 & 0.74 & $<0.13$ & $<0.13$ & 0.19 & 0.24 \\
\hline \%RSD & 0.02 & 0.02 & 0.01 & 0.01 & 0.04 & 0.00 \\
\hline
\end{tabular}

Table F 3. REPEAT SIM A GRANULAR PRODUCT ICPMS Cs-Re

\begin{tabular}{|l|c|c|}
\hline \multirow{2}{*}{ Sample } & $\mathbf{w t} \%$ & $\mathbf{w t} \%$ \\
\cline { 2 - 3 } & $\mathbf{C s}$ & $\mathbf{R e}$ \\
\hline 1 & 0.034 & 0.047 \\
\hline 2 & 0.032 & 0.044 \\
\hline 3 & 0.035 & 0.046 \\
\hline Average & 0.034 & 0.046 \\
\hline Standard Deviation & 0.001 & 0.002 \\
\hline \%RSD & $4.28 \%$ & $3.50 \%$ \\
\hline
\end{tabular}

The DMR condensate filtrate cation or ICPES concentrations from the composite of the runs for REPEAT Simulant A module are shown in Table F 4. The average values are used in the mass balance.

The DMR condensate filtrate anion or IC concentrations from the composite of the runs for REPEAT

Simulant A module are shown in Table F 5. The average values are used in the mass balance. 
Table F 4. REPEAT SIM A DMR CONDENSATE COMPOSITE FILTRATE ICPES Ag-Zn

\begin{tabular}{|c|c|c|c|c|c|c|c|c|c|c|c|c|c|c|}
\hline \multirow{2}{*}{ Run } & L & \multirow[b]{2}{*}{ Sample } & $\mathrm{mg} / \mathrm{L}$ & $\mathrm{mg} / \mathrm{L}$ & $\mathrm{mg} / \mathrm{L}$ & $\mathrm{mg} / \mathrm{L}$ & $\mathrm{mg} / \mathrm{L}$ & $\mathrm{mg} / \mathrm{L}$ & $\mathrm{mg} / \mathrm{L}$ & $\mathrm{mg} / \mathrm{L}$ & $\mathrm{mg} / \mathrm{L}$ & $\mathrm{mg} / \mathrm{L}$ & $\mathrm{mg} / \mathrm{L}$ & $\mathrm{mg} / \mathrm{L}$ \\
\hline & Volume & & $\mathrm{Ag}$ & Al & B & $\mathrm{Cr}$ & $\mathbf{K}$ & $\mathrm{Na}$ & $\mathrm{Ni}$ & 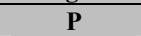 & $\mathrm{Pb}$ & $\mathrm{S}$ & $\mathrm{Si}$ & $\mathbf{Z n}$ \\
\hline \multirow{6}{*}{ Composite } & \multirow{6}{*}{1.0167} & 1 & $<8.50 \mathrm{E}-02$ & $3.43 \mathrm{E}-01$ & $2.13 \mathrm{E}+00$ & $<2.80 \mathrm{E}-02$ & $<4.89 \mathrm{E}-01$ & $2.88 \mathrm{E}+00$ & $<3.80 \mathrm{E}-02$ & $<9.60 \mathrm{E}-02$ & $<9.20 \mathrm{E}-02$ & $1.18 \mathrm{E}+01$ & $6.67 \mathrm{E}+00$ & $<3.60 \mathrm{E}-02$ \\
\hline & & 2 & $<8.50 \mathrm{E}-02$ & $3.98 \mathrm{E}-01$ & $2.24 \mathrm{E}+00$ & $<2.80 \mathrm{E}-02$ & $<4.89 \mathrm{E}-01$ & $2.95 \mathrm{E}+00$ & $<3.80 \mathrm{E}-02$ & $<9.60 \mathrm{E}-02$ & $<9.20 \mathrm{E}-02$ & $1.27 \mathrm{E}+01$ & $9.31 \mathrm{E}+00$ & $<3.60 \mathrm{E}-02$ \\
\hline & & 3 & $<8.50 \mathrm{E}-02$ & $3.46 \mathrm{E}-01$ & $2.23 \mathrm{E}+00$ & $<2.80 \mathrm{E}-02$ & $<4.89 \mathrm{E}-01$ & $3.00 \mathrm{E}+00$ & $<3.80 \mathrm{E}-02$ & $<9.60 \mathrm{E}-02$ & $<9.20 \mathrm{E}-02$ & $1.24 \mathrm{E}+01$ & $8.63 \mathrm{E}+00$ & $<3.60 \mathrm{E}-02$ \\
\hline & & Average & $<8.50 \mathrm{E}-02$ & $3.62 \mathrm{E}-01$ & $2.20 \mathrm{E}+00$ & $<2.80 \mathrm{E}-02$ & $<4.89 \mathrm{E}-01$ & $2.94 \mathrm{E}+00$ & $<3.80 \mathrm{E}-02$ & $<9.60 \mathrm{E}-02$ & $<9.20 \mathrm{E}-02$ & $1.23 \mathrm{E}+01$ & $8.20 \mathrm{E}+00$ & $<3.60 \mathrm{E}-02$ \\
\hline & & $\begin{array}{c}\text { Standard } \\
\text { Deviation }\end{array}$ & na & $3.09 \mathrm{E}-02$ & $6.08 \mathrm{E}-02$ & na & $6.80 \mathrm{E}-17$ & $6.03 \mathrm{E}-02$ & na & na & na & $4.58 \mathrm{E}-01$ & $1.37 \mathrm{E}+00$ & na \\
\hline & & \%RSD & na & $8.53 \%$ & $2.76 \%$ & na & $0.00 \%$ & $2.05 \%$ & na & na & na & $3.73 \%$ & $16.71 \%$ & na \\
\hline
\end{tabular}

Table F 5. REPEAT SIM A DMR CONDENSATE COMPOSITE FILTRATE IC F-PO4

\begin{tabular}{|c|c|c|c|c|c|c|c|c|}
\hline \multirow{2}{*}{ Run } & $\mathbf{L}$ & \multirow{2}{*}{ Sample } & ug/L & ug/L & ug/L & ug/L & ug/L & ug/L \\
\hline & Volume & & $\mathbf{F}$ & $\mathrm{Cl}$ & NO2 & NO3 & SO4 & PO4 \\
\hline \multirow{6}{*}{ Composite } & \multirow{6}{*}{1.0167} & 1 & $2.00 \mathrm{E}+04$ & $1.30 \mathrm{E}+04$ & $1.89 \mathrm{E}+05$ & $1.60 \mathrm{E}+04$ & $1.30 \mathrm{E}+04$ & $<1.00 \mathrm{E}+04$ \\
\hline & & 2 & $2.00 \mathrm{E}+04$ & $1.30 \mathrm{E}+04$ & $1.90 \mathrm{E}+05$ & $1.80 \mathrm{E}+04$ & $1.30 \mathrm{E}+04$ & $<1.00 \mathrm{E}+04$ \\
\hline & & 3 & $2.00 \mathrm{E}+04$ & $1.30 \mathrm{E}+04$ & $1.92 \mathrm{E}+05$ & $1.80 \mathrm{E}+04$ & $1.40 \mathrm{E}+04$ & $<1.00 \mathrm{E}+04$ \\
\hline & & Average & $2.00 \mathrm{E}+04$ & $1.30 \mathrm{E}+04$ & $1.90 \mathrm{E}+05$ & $1.73 \mathrm{E}+04$ & $1.33 \mathrm{E}+04$ & $<1.00 \mathrm{E}+04$ \\
\hline & & Standard Deviation & $0.00 \mathrm{E}+00$ & $0.00 \mathrm{E}+00$ & $1.53 \mathrm{E}+03$ & $1.15 \mathrm{E}+03$ & $5.77 \mathrm{E}+02$ & na \\
\hline & & $\%$ RSD & $0.00 \%$ & $0.00 \%$ & $0.80 \%$ & $6.66 \%$ & $4.33 \%$ & na \\
\hline
\end{tabular}


The DMR condensate filtrate trace elemental or ICPMS concentrations from the composite of the runs for Simulant A module are shown in Table F 6 . The average values are used in the mass balance.

Table F 6. REPEAT SIM A DMR CONDENSATE FILTRATES ICPMS Cs, Re, I

\begin{tabular}{|c|c|c|c|c|c|}
\hline \multirow{3}{*}{ Run } & $\mathbf{L}$ & \multirow{2}{*}{ Sample } & $\mathbf{u g} / \mathbf{L}$ & $\mathbf{u g} / \mathbf{L}$ & $\mathbf{u g} / \mathbf{L}$ \\
\cline { 2 - 5 } & Volume & $\mathbf{C s}$ & $\mathbf{R e}$ & $\mathbf{I}$ \\
\hline \multirow{4}{*}{ Composite } & \multirow{3}{*}{1.0167} & 1 & $1.69 \mathrm{E}+02$ & $3.39 \mathrm{E}+02$ & $5.18 \mathrm{E}+02$ \\
\cline { 3 - 5 } & & 2 & $1.70 \mathrm{E}+02$ & $3.40 \mathrm{E}+02$ & $5.22 \mathrm{E}+02$ \\
\cline { 3 - 5 } & & 3 & $1.68 \mathrm{E}+02$ & $3.42 \mathrm{E}+02$ & $5.23 \mathrm{E}+02$ \\
\cline { 3 - 5 } & & Average & $1.69 \mathrm{E}+02$ & $3.40 \mathrm{E}+02$ & $5.21 \mathrm{E}+02$ \\
\cline { 3 - 5 } & & Standard Deviation & $1.00 \mathrm{E}+00$ & $1.53 \mathrm{E}+00$ & $2.65 \mathrm{E}+00$ \\
\cline { 3 - 5 } & & \%RSD & $0.59 \%$ & $0.45 \%$ & $0.51 \%$ \\
\hline
\end{tabular}

The DMR condensate filtered solids were too low $(0.0253 \mathrm{~g})$ to collect and perform analyses on so the concentrations were assumed to match those for the granular product and the small additional mass was assumed part of the DMR granular product for the mass balance.

There were no crossbar rinse filtrates since Quartz Wool was used in the crossbar to catch solids which is discussed next.

The crossbar solids concentrations from the composite runs for REPEAT Simulant A module are shown in Table F 7. Note that the concentrations were adjusted for the quartz wool (clean quartz wool samples were used as blanks). These composite values are used in the mass balance.

Table F 7. REPEAT SIM A CROSSBAR COMPOSITE FILTERED SOLIDS ICPES Ag-Zn

\begin{tabular}{|c|c|c|c|c|c|c|c|c|c|c|c|c|c|}
\hline \multirow{2}{*}{ Run } & $\mathbf{g}$ & $\mathbf{w t} \%$ & $\mathbf{w t} \%$ & $\mathbf{w t} \%$ & $\mathbf{w t} \%$ & $\mathbf{w t} \%$ & $\mathbf{w t} \%$ & $\mathbf{w t} \%$ & $\mathbf{w t} \%$ & $\mathbf{w t} \%$ & $\mathbf{w t} \%$ & $\mathbf{w t} \%$ & $\mathbf{w t} \%$ \\
\cline { 2 - 17 } & $\mathbf{M a s s}$ & $\mathbf{A g}$ & $\mathbf{A l}$ & $\mathbf{B}$ & $\mathbf{C r}$ & $\mathbf{K}$ & $\mathbf{N a}$ & $\mathbf{N i}$ & $\mathbf{P}$ & $\mathbf{P b}$ & $\mathbf{S}$ & $\mathbf{S i}$ & $\mathbf{Z n}$ \\
\hline Composite & 1.293 & $<0.001$ & 5.27 & 0.47 & 0.03 & 0.12 & 4.98 & 0.002 & 0.04 & 0.01 & 0.71 & 5.41 & 0.03 \\
\hline
\end{tabular}

The DMR crossbar solids anion or IC concentrations from the composite of the runs for REPEAT Simulant A module are shown in Table F 8. The composite values are used in the mass balance.

Table F 8. REPEAT SIM A CROSSBAR COMPOSITE FILTERED SOLIDS IC SO4-PO4

\begin{tabular}{|c|c|c|c|c|c|c|c|}
\hline \multirow{2}{*}{ Run } & $\mathbf{g}$ & $\mathbf{w t} \%$ & $\mathbf{w t} \%$ & $\mathbf{w t} \%$ & $\mathbf{w t} \%$ & $\mathbf{w t} \%$ & $\mathbf{w t} \%$ \\
\cline { 2 - 8 } & Mass & $\mathbf{F}$ & $\mathbf{C l}$ & $\mathbf{N O 2}$ & $\mathbf{N O 3}$ & $\mathbf{S O 4}$ & $\mathbf{P O 4}$ \\
\hline Composite & 1.293 & 22.58 & 4.38 & $<0.35$ & 9.52 & $<0.88$ & $<0.35$ \\
\hline
\end{tabular}

The crossbar rinse filtered solids trace elemental or ICPMS concentrations the composite of the runs for Repeat Simulant A module are shown in Table F 9. The composite values are used in the mass balance.

Table F 9. REPEAT SIM A CROSSBAR COMPOSITE FILTERED SOLIDS ICPMS Cs, Re, I

\begin{tabular}{|c|c|c|c|c|}
\hline \multirow{2}{*}{ Run } & $\mathbf{g}$ & $\mathbf{w t} \%$ & $\mathbf{w t} \%$ & $\mathbf{w t} \%$ \\
\cline { 2 - 5 } & Mass & Cs & $\mathbf{R e}$ & $\mathbf{I}$ \\
\hline Composite & 1.293 & 0.046 & 0.050 & 0.062 \\
\hline
\end{tabular}


Two sets of samples were taken from the seal pot legs of the BSR. The first set was seal pot leg condensate drains that were then filtered. The second set was seal pot leg deionized water rinses that were then filtered. Both the filtrate and filtered solids from the two sets were submitted for analyses.

The seal pot leg condensate drains cation or ICPES concentrations from the composite of the runs for REPEAT Simulant A module are shown in Table F-10. The average values are used in the mass balance. 
Table F 10. REPEAT SIM A SEAL POT LEG CONDENSATE DRAINS COMPOSITE FILTRATE ICPES Ag-Zn

\begin{tabular}{|c|c|c|c|c|c|c|c|c|c|c|c|c|c|c|}
\hline \multirow{2}{*}{ Run } & \multirow{2}{*}{$\begin{array}{c}\text { L } \\
\text { Volume }\end{array}$} & \multirow{2}{*}{ Sample } & $\mathrm{mg} / \mathrm{L}$ & $\mathrm{mg} / \mathrm{L}$ & $\mathrm{mg} / \mathrm{L}$ & $\mathrm{mg} / \mathrm{L}$ & $\mathrm{mg} / \mathrm{L}$ & $\mathrm{mg} / \mathrm{L}$ & $\mathrm{mg} / \mathrm{L}$ & $\mathrm{mg} / \mathrm{L}$ & $\mathrm{mg} / \mathrm{L}$ & $\mathrm{mg} / \mathrm{L}$ & $\mathrm{mg} / \mathrm{L}$ & $\mathrm{mg} / \mathrm{L}$ \\
\hline & & & Ag & Al & B & $\mathrm{Cr}$ & $\mathbf{K}$ & $\mathrm{Na}$ & $\mathbf{N i}$ & $\mathbf{P}$ & $\mathbf{P b}$ & $\mathbf{S}$ & $\mathrm{Si}$ & $\mathbf{Z n}$ \\
\hline \multirow{6}{*}{ Composite } & \multirow{6}{*}{0.1107} & 1 & $<8.50 \mathrm{E}-02$ & $2.42 \mathrm{E}+00$ & $1.34 \mathrm{E}+01$ & $2.80 \mathrm{E}-02$ & $9.49 \mathrm{E}-01$ & $4.47 \mathrm{E}+01$ & $<3.80 \mathrm{E}-02$ & $1.02 \mathrm{E}-01$ & $<9.20 \mathrm{E}-02$ & $3.10 \mathrm{E}+01$ & $4.62 \mathrm{E}+01$ & $4.90 \mathrm{E}-02$ \\
\hline & & 2 & $<8.50 \mathrm{E}-02$ & $2.36 \mathrm{E}+00$ & $1.36 \mathrm{E}+01$ & $<2.80 \mathrm{E}-02$ & $8.37 \mathrm{E}-01$ & $4.48 \mathrm{E}+01$ & $<3.80 \mathrm{E}-02$ & $1.16 \mathrm{E}-01$ & $<9.20 \mathrm{E}-02$ & $3.08 \mathrm{E}+01$ & $6.41 \mathrm{E}+01$ & $5.00 \mathrm{E}-02$ \\
\hline & & 3 & $<8.50 \mathrm{E}-02$ & $2.41 \mathrm{E}+00$ & $1.38 \mathrm{E}+01$ & $<2.80 \mathrm{E}-02$ & $7.63 \mathrm{E}-01$ & $4.48 \mathrm{E}+01$ & $<3.80 \mathrm{E}-02$ & $1.08 \mathrm{E}-01$ & $<9.20 \mathrm{E}-02$ & $3.12 \mathrm{E}+01$ & $6.99 \mathrm{E}+01$ & $5.70 \mathrm{E}-02$ \\
\hline & & Average & $<8.50 \mathrm{E}-02$ & $2.40 \mathrm{E}+00$ & $1.36 \mathrm{E}+01$ & $2.80 \mathrm{E}-02$ & $8.50 \mathrm{E}-01$ & $4.48 \mathrm{E}+01$ & $<3.80 \mathrm{E}-02$ & $1.09 \mathrm{E}-01$ & $<9.20 \mathrm{E}-02$ & $3.10 \mathrm{E}+01$ & $6.01 \mathrm{E}+01$ & $5.20 \mathrm{E}-02$ \\
\hline & & $\begin{array}{c}\text { Standard } \\
\text { Deviation }\end{array}$ & na & $3.21 \mathrm{E}-02$ & $2.00 \mathrm{E}-01$ & $0.00 \mathrm{E}+00$ & $9.36 \mathrm{E}-02$ & $5.77 \mathrm{E}-02$ & na & $7.02 \mathrm{E}-03$ & na & $2.00 \mathrm{E}-01$ & $1.24 \mathrm{E}+01$ & $4.36 \mathrm{E}-03$ \\
\hline & & \%RSD & na & $1.34 \%$ & $1.47 \%$ & $0.00 \%$ & $11.02 \%$ & $0.13 \%$ & na & $6.46 \%$ & na & $0.65 \%$ & $20.57 \%$ & $8.38 \%$ \\
\hline
\end{tabular}

The seal pot leg condensate drains anion or IC concentrations from the composite of the runs for REPEAT Simulant A module are shown in Table F 11. The average values are used in the mass balance.

Table F 11. REPEAT SIM A SEAL POT LEG CONDENSATE DRAINS COMPOSITE FILTRATE IC F-PO 4

\begin{tabular}{|c|c|c|c|c|c|c|c|c|}
\hline \multirow{2}{*}{ Run } & \multirow{2}{*}{$\begin{array}{c}\text { L } \\
\text { Volume }\end{array}$} & \multirow{2}{*}{ Sample } & ug/L & ug/L & ug/L & ug/L & ug/L & ug/L \\
\hline & & & $\mathbf{F}$ & $\mathrm{CI}$ & $\mathrm{NO}_{2}$ & $\mathrm{NO}_{3}$ & $\mathrm{SO}_{4}$ & $\mathrm{PO}_{4}$ \\
\hline \multirow{6}{*}{ Composite } & \multirow{6}{*}{0.1107} & 1 & $2.76 \mathrm{E}+05$ & $1.15 \mathrm{E}+05$ & $9.35 \mathrm{E}+05$ & $8.26 \mathrm{E}+05$ & $4.00 \mathrm{E}+04$ & $<1.00 \mathrm{E}+04$ \\
\hline & & 2 & $2.64 \mathrm{E}+05$ & $1.14 \mathrm{E}+05$ & $9.47 \mathrm{E}+05$ & $8.64 \mathrm{E}+05$ & $4.00 \mathrm{E}+04$ & $<1.00 \mathrm{E}+04$ \\
\hline & & 3 & $2.91 \mathrm{E}+05$ & $1.15 \mathrm{E}+05$ & $9.54 \mathrm{E}+05$ & $8.73 \mathrm{E}+05$ & $4.00 \mathrm{E}+04$ & $<1.00 \mathrm{E}+04$ \\
\hline & & Average & $2.77 \mathrm{E}+05$ & $1.15 \mathrm{E}+05$ & $9.45 \mathrm{E}+05$ & $8.54 \mathrm{E}+05$ & $4.00 \mathrm{E}+04$ & $<1.00 \mathrm{E}+04$ \\
\hline & & Standard Deviation & $1.35 \mathrm{E}+04$ & $5.77 \mathrm{E}+02$ & $9.61 \mathrm{E}+03$ & $2.49 \mathrm{E}+04$ & $0.00 \mathrm{E}+00$ & na \\
\hline & & $\%$ RSD & $4.88 \%$ & $0.50 \%$ & $1.02 \%$ & $2.92 \%$ & $0.00 \%$ & na \\
\hline
\end{tabular}

The seal pot leg condensate drains filtrate trace elemental or ICPMS concentrations from the composite of the runs for Repeat Simulant A module are shown in Table F 12. The average values are used in the mass balance. 
SRNL-STI-2011-00331

Revision 0

Table F 12. REPEAT SIM A SEAL POT LEG CONDENSATE DRAINS COMPOSITE FILTRATES ICPMS Cs, Re, I

\begin{tabular}{|c|c|c|c|c|c|}
\hline \multirow{3}{*}{ Run } & $\mathbf{L}$ & \multirow{2}{*}{ Sample } & $\mathbf{u g} / \mathbf{L}$ & $\mathbf{u g} / \mathbf{L}$ & $\mathbf{u g} / \mathbf{L}$ \\
\cline { 2 - 5 } & Volume & & $\mathbf{C s}$ & $\mathbf{R e}$ & $\mathbf{I}$ \\
\hline \multirow{3}{*}{ Composite } & \multirow{4}{*}{0.1107} & 1 & $1.00 \mathrm{E}+03$ & $1.79 \mathrm{E}+03$ & $4.87 \mathrm{E}+03$ \\
\cline { 3 - 5 } & & 2 & $9.75 \mathrm{E}+02$ & $1.75 \mathrm{E}+03$ & $4.95 \mathrm{E}+03$ \\
\cline { 3 - 5 } & & 3 & $1.01 \mathrm{E}+03$ & $1.80 \mathrm{E}+03$ & $4.85 \mathrm{E}+03$ \\
\cline { 3 - 5 } & & Average & $9.95 \mathrm{E}+02$ & $1.78 \mathrm{E}+03$ & $4.89 \mathrm{E}+03$ \\
\cline { 3 - 5 } & & Standard Deviation & $1.80 \mathrm{E}+01$ & $2.65 \mathrm{E}+01$ & $5.29 \mathrm{E}+01$ \\
\cline { 3 - 5 } & & \%RSD & $1.81 \%$ & $1.49 \%$ & $1.08 \%$ \\
\hline
\end{tabular}

The seal pot leg condensate drains filtered solids concentrations from the composite runs for REPEAT Simulant A module are shown in Table F 13. These values are used in the mass balance.

Table F 13. REPEAT SIM A SEAL POT LEG CONDENSATE DRAINS COMPOSITE FILTERED SOLIDS ICPES Ag-Zn

\begin{tabular}{|c|c|c|c|c|c|c|c|c|c|c|c|c|c|}
\hline \multirow{2}{*}{ Run } & $\mathbf{g}$ & $\mathbf{w t} \%$ & $\mathbf{w t} \%$ & $\mathbf{w t} \%$ & $\mathbf{w t} \%$ & $\mathbf{w t} \%$ & $\mathbf{w t} \%$ & $\mathbf{w t} \%$ & $\mathbf{w t} \%$ & $\mathbf{w t} \%$ & $\mathbf{w t} \%$ & $\mathbf{w t} \%$ & $\mathbf{w t} \%$ \\
& Mass & $\mathbf{A g}$ & $\mathbf{A l}$ & $\mathbf{B}$ & $\mathbf{C r}$ & $\mathbf{K}$ & $\mathbf{N a}$ & $\mathbf{N i}$ & $\mathbf{P}$ & $\mathbf{P b}$ & $\mathbf{S}$ & $\mathbf{S i}$ & $\mathbf{Z n}$ \\
\hline Composite & 0.0217 & $<0.01$ & 21.20 & 0.27 & 0.06 & $<0.14$ & 1.87 & $<0.005$ & 0.19 & $<0.03$ & 0.26 & 0.91 & 0.12 \\
\hline
\end{tabular}

Anion or IC analyses were not performed on the REPEAT SIM A seal pot leg condensate drains filtered solids due to lack of sample but the $\mathrm{SO}_{4}$ and $\mathrm{PO}_{4}$ concentrations can be estimated from the $\mathrm{S}$ and $\mathrm{P}$ analyses as shown earlier for crossbar rinse filtered solids for SIM A. Using this same logic, the estimated $\mathrm{SO}_{4}$ and $\mathrm{PO}_{4}$ concentrations for the seal pot leg condensate drains filtered solids are shown in Table $\mathrm{F} 14$.

Table F 14. SIM A SEAL POT LEG CONDENSATE DRAINS COMPOSITE FILTERED SOLIDS IC SO4-PO4

\begin{tabular}{|c|c|c|c|}
\hline \multirow{2}{*}{ Run } & $\mathbf{g}$ & $\mathbf{w t} \%$ & $\mathbf{w t} \%$ \\
\cline { 2 - 4 } & Mass & $\mathbf{S O}_{4}$ & $\mathbf{P O}_{4}$ \\
\hline Composite & 0.0217 & 0.57 & 0.77 \\
\hline
\end{tabular}

The seal pot leg condensate drains filtered solids trace elemental or ICPMS concentrations for the composite of the runs for Repeat Simulant A module are shown in Table F 15. The composite values are used in the mass balance.

Table F 15. REPEAT SIM A CROSSBAR COMPOSITE FILTERED SOLIDS ICPMS Cs, Re, I

\begin{tabular}{|c|c|c|c|c|}
\hline \multirow{2}{*}{ Run } & $\mathbf{g}$ & $\mathbf{w t} \%$ & $\mathbf{w t} \%$ & $\mathbf{w t} \%$ \\
\cline { 2 - 5 } & Mass & $\mathbf{C s}$ & $\mathbf{R e}$ & $\mathbf{I}$ \\
\hline Composite & 0.0217 & 0.013 & 0.008 & 0.011 \\
\hline
\end{tabular}

The seal pot legs were rinsed with deionized water and the rinse was then filtered. The seal pot leg rinse filtrate cation or ICPES concentrations from the composite of the runs for REPEAT Simulant A module are shown in Table F 16. The average values are used in the mass balance. 
Table F 16. REPEAT SIM A SEAL POT LEG RINSE COMPOSITE FILTRATE ICPES Ag-Zn

\begin{tabular}{|c|c|c|c|c|c|c|c|c|c|c|c|c|c|c|}
\hline \multirow{2}{*}{ Run } & L & \multirow{2}{*}{ Sample } & $\mathrm{mg} / \mathrm{L}$ & $\mathrm{mg} / \mathrm{L}$ & $\mathrm{mg} / \mathrm{L}$ & $\mathrm{mg} / \mathrm{L}$ & $\mathrm{mg} / \mathrm{L}$ & $\mathrm{mg} / \mathrm{L}$ & $\mathrm{mg} / \mathrm{L}$ & $\mathrm{mg} / \mathrm{L}$ & $\mathrm{mg} / \mathrm{L}$ & $\mathrm{mg} / \mathrm{L}$ & $\mathrm{mg} / \mathrm{L}$ & $\mathrm{mg} / \mathrm{L}$ \\
\hline & Volume & & Ag & $\mathrm{Al}$ & B & $\mathrm{Cr}$ & $\mathbf{K}$ & $\mathrm{Na}$ & $\mathrm{Ni}$ & $\mathbf{P}$ & $\mathbf{P b}$ & S & $\mathrm{Si}$ & $\mathbf{Z n}$ \\
\hline \multirow{6}{*}{ Composite } & \multirow{6}{*}{0.3359} & 1 & $<8.50 \mathrm{E}-02$ & $1.21 \mathrm{E}-01$ & $1.39 \mathrm{E}-01$ & $<2.80 \mathrm{E}-02$ & $<4.89 \mathrm{E}-01$ & $<3.40 \mathrm{E}+00$ & $<3.80 \mathrm{E}-02$ & $<9.60 \mathrm{E}-02$ & $<9.20 \mathrm{E}-02$ & $4.34 \mathrm{E}-01$ & $1.52 \mathrm{E}+00$ & $<3.60 \mathrm{E}-02$ \\
\hline & & 2 & $<8.50 \mathrm{E}-02$ & $<1.09 \mathrm{E}-01$ & $1.24 \mathrm{E}-01$ & $<2.80 \mathrm{E}-02$ & $<4.89 \mathrm{E}-01$ & $3.37 \mathrm{E}+00$ & $<3.80 \mathrm{E}-02$ & $<9.60 \mathrm{E}-02$ & $<9.20 \mathrm{E}-02$ & $4.06 \mathrm{E}-01$ & $1.47 \mathrm{E}+00$ & $<3.60 \mathrm{E}-02$ \\
\hline & & 3 & $<8.50 \mathrm{E}-02$ & $1.50 \mathrm{E}-01$ & $1.17 \mathrm{E}-01$ & $<2.80 \mathrm{E}-02$ & $<4.89 \mathrm{E}-01$ & $3.28 \mathrm{E}+00$ & $<3.80 \mathrm{E}-02$ & $<9.60 \mathrm{E}-02$ & $<9.20 \mathrm{E}-02$ & $4.07 \mathrm{E}-01$ & $1.43 \mathrm{E}+00$ & $<3.60 \mathrm{E}-02$ \\
\hline & & Average & $<8.50 \mathrm{E}-02$ & $1.36 \mathrm{E}-01$ & $1.27 \mathrm{E}-01$ & $<2.80 \mathrm{E}-02$ & $<4.89 \mathrm{E}-01$ & $3.33 \mathrm{E}+00$ & $<3.80 \mathrm{E}-02$ & $<9.60 \mathrm{E}-02$ & $<9.20 \mathrm{E}-02$ & $4.16 \mathrm{E}-01$ & $1.47 \mathrm{E}+00$ & $<3.60 \mathrm{E}-02$ \\
\hline & & $\begin{array}{c}\text { Standard } \\
\text { Deviation }\end{array}$ & na & $2.05 \mathrm{E}-02$ & $1.12 \mathrm{E}-02$ & na & na & $6.36 \mathrm{E}-02$ & na & na & na & $1.59 \mathrm{E}-02$ & 4.51E-02 & na \\
\hline & & $\%$ RSD & na & $15.13 \%$ & $8.87 \%$ & na & na & $1.91 \%$ & na & na & na & $3.82 \%$ & $3.06 \%$ & na \\
\hline
\end{tabular}

The seal pot leg rinse filtrate anion or IC concentrations from the composite of the runs for REPEAT Simulant A module are shown in Table F 17. The average values are used in the mass balance.

Table F 17. REPEAT SIM A SEAL POT LEG RINSE COMPOSITE FILTRATE IC F-PO

\begin{tabular}{|c|c|c|c|c|c|c|c|c|}
\hline \multirow{2}{*}{ Run } & $\mathbf{L}$ & \multirow{2}{*}{ Sample } & ug/L & ug/L & ug/L & ug/L & ug/L & ug/L \\
\hline & Volume & & $\mathbf{F}$ & CI & $\mathbf{N O}_{2}$ & $\mathrm{NO}_{3}$ & $\mathrm{SO}_{4}$ & $\mathbf{P O}_{4}$ \\
\hline \multirow{6}{*}{ Composite } & \multirow{6}{*}{0.3359} & 1 & $9.00 \mathrm{E}+03$ & $<1.00 \mathrm{E}+04$ & $1.20 \mathrm{E}+04$ & $8.00 \mathrm{E}+03$ & $<1.00 \mathrm{E}+04$ & $<1.00 \mathrm{E}+04$ \\
\hline & & 2 & $9.00 \mathrm{E}+03$ & $<1.00 \mathrm{E}+04$ & $1.20 \mathrm{E}+04$ & $8.00 \mathrm{E}+03$ & $<1.00 \mathrm{E}+04$ & $<1.00 \mathrm{E}+04$ \\
\hline & & 3 & $9.00 \mathrm{E}+03$ & $<1.00 \mathrm{E}+04$ & $1.20 \mathrm{E}+04$ & $8.00 \mathrm{E}+03$ & $<1.00 \mathrm{E}+04$ & $<1.00 \mathrm{E}+04$ \\
\hline & & Average & $9.00 \mathrm{E}+03$ & $<1.00 \mathrm{E}+04$ & $1.20 \mathrm{E}+04$ & $8.00 \mathrm{E}+03$ & $<1.00 \mathrm{E}+04$ & $<1.00 \mathrm{E}+04$ \\
\hline & & Standard Deviation & $0.00 \mathrm{E}+00$ & na & $0.00 \mathrm{E}+00$ & $0.00 \mathrm{E}+00$ & na & na \\
\hline & & $\%$ RSD & $0.00 \%$ & na & $0.00 \%$ & $0.00 \%$ & na & na \\
\hline
\end{tabular}

The seal pot leg rinse filtrate trace elemental or ICPMS concentrations from the composite of the runs for Simulant A module are shown in Table $\mathrm{F} 18$. The average values are used in the mass balance. 
Table F 18. REPEAT SIM A SEAL POT LEG RINSE COMPOSITE FILTRATE ICPMS Cs, Re, I

\begin{tabular}{|c|c|c|c|c|c|}
\hline \multirow{3}{*}{ Run } & $\mathbf{L}$ & \multirow{2}{*}{ Sample } & $\mathbf{u g} / \mathbf{L}$ & $\mathbf{u g} / \mathbf{L}$ & $\mathbf{u g} / \mathbf{L}$ \\
\cline { 2 - 5 } \cline { 3 - 5 } & Volume & $\mathbf{C r}$ & $\mathbf{R e}$ & $\mathbf{I}$ \\
\hline \multirow{3}{*}{ Composite } & & 1 & $1.78 \mathrm{E}+01$ & $1.75 \mathrm{E}+01$ & $5.44 \mathrm{E}+01$ \\
\cline { 3 - 6 } & \multirow{3}{*}{0.3359} & 2 & $1.71 \mathrm{E}+01$ & $1.73 \mathrm{E}+01$ & $5.61 \mathrm{E}+01$ \\
\cline { 3 - 6 } & & 3 & $1.73 \mathrm{E}+01$ & $1.75 \mathrm{E}+01$ & $5.67 \mathrm{E}+01$ \\
\cline { 3 - 6 } & & Average & $1.74 \mathrm{E}+01$ & $1.74 \mathrm{E}+01$ & $5.57 \mathrm{E}+01$ \\
\cline { 3 - 6 } & & Standard Deviation & $3.61 \mathrm{E}-01$ & $1.15 \mathrm{E}-01$ & $1.19 \mathrm{E}+00$ \\
\cline { 3 - 6 } & & \%RSD & $2.07 \%$ & $0.66 \%$ & $2.14 \%$ \\
\hline
\end{tabular}

The seal pot leg rinse filtered solids concentrations from the composite of the runs for REPEAT Simulant A module are shown in Table F 19. The composite values are used in the mass balance.

Table F 19. REPEAT SIM A SEAL POT LEG RINSE COMPOSITE FILTERED SOLIDS ICPES Ag-Zn

\begin{tabular}{|c|c|c|c|c|c|c|c|c|c|c|c|c|c|}
\hline \multirow[t]{2}{*}{ Run } & g & $w t \%$ & wt\% & $\begin{array}{l}\text { wt } \\
\%\end{array}$ & $\begin{array}{l}\text { wt } \\
\%\end{array}$ & $\begin{array}{l}\text { wt } \\
\%\end{array}$ & $\begin{array}{l}\text { wt } \\
\%\end{array}$ & $\begin{array}{l}\text { wt } \\
\%\end{array}$ & $\begin{array}{l}\text { wt } \\
\%\end{array}$ & $\begin{array}{l}\text { wt } \\
\%\end{array}$ & $\begin{array}{l}\text { wt } \\
\%\end{array}$ & $\begin{array}{l}\text { wt } \\
\%\end{array}$ & $\begin{array}{l}\text { wt } \\
\% \%\end{array}$ \\
\hline & Mass & $\mathbf{A g}$ & Al & $\mathbf{B}$ & $\mathrm{Cr}$ & $\bar{K}$ & $\mathbf{N a}$ & $\mathbf{N i}$ & $\mathbf{P}$ & $\mathbf{P b}$ & $\mathbf{S}$ & $\mathbf{S i}$ & $\mathbf{Z n}$ \\
\hline Composite & 0.0631 & $<0.003$ & 8.78 & 0.06 & 0.09 & 0.17 & 2.85 & 0.01 & 0.07 & 0.01 & 0.18 & 0.32 & 0.08 \\
\hline
\end{tabular}

Anion or IC analyses were not performed on the REPEAT SIM A seal pot leg rinse filtered solids due to lack of sample but the $\mathrm{SO}_{4}$ and $\mathrm{PO}_{4}$ concentrations can be estimated from the $\mathrm{S}$ and $\mathrm{P}$ analyses as shown earlier for crossbar rinse filtered solids for SIM A. Using this same logic, the estimated $\mathrm{SO}_{4}$ and $\mathrm{PO}_{4}$ concentrations for the seal pot leg condensate drains filtered solids are shown in Table F 20.

Table F 20. SIM A SEAL POT LEG CONDENSATE DRAINS COMPOSITE FILTERED SOLIDS $\mathrm{IC} \mathrm{SO}_{4}-\mathrm{PO}_{4}$

\begin{tabular}{|c|c|c|c|}
\hline \multirow{2}{*}{ Run } & $\mathbf{g}$ & $\mathbf{w t} \%$ & $\mathbf{w t} \%$ \\
\cline { 2 - 4 } & Mass & $\mathbf{S O}_{4}$ & $\mathbf{P O}_{4}$ \\
\hline Composite & 0.0631 & 0.54 & 0.21 \\
\hline
\end{tabular}

The seal pot leg rinse filtered solids trace elemental or ICPMS concentrations from the composite of the runs for Repeat Simulant A module are shown in Table F 21. The composite values are used in the mass balance.

Table F 21. REPEAT SIM A CROSSBAR COMPOSITE FILTERED SOLIDS ICPMS Cs, Re, I

\begin{tabular}{|c|c|c|c|c|}
\hline \multirow{2}{*}{ Run } & $\mathbf{g}$ & $\mathbf{w t} \%$ & $\mathbf{w t} \%$ & $\mathbf{w t} \%$ \\
\cline { 2 - 5 } & Mass & $\mathbf{C s}$ & $\mathbf{R e}$ & $\mathbf{I}$ \\
\hline Composite & 0.0631 & 0.030 & 0.024 & 0.020 \\
\hline
\end{tabular}




\section{Appendix G. Sample Analyses for Radioactive WTP SW Campaign in Fall 2010}

Table G 1 through Table G 3 gives the ICPES, IC, and ICPMS concentrations for the Radioactive A granular product samples. The average concentrations are used in the mass balance.

Table G 1. RAD A GRANULAR PRODUCT ICPES Ag-Zn

\begin{tabular}{|c|c|c|c|c|c|c|c|c|c|c|c|c|}
\hline \multirow{2}{*}{ Sample } & wt $\%$ & wt $\%$ & wt $\%$ & wt $\%$ & $w t \%$ & wt $\%$ & wt $\%$ & wt \% & wt $\%$ & wt $\%$ & wt \% & $w t \%$ \\
\hline & Ag & Al & B & $\mathrm{Cr}$ & $\mathbf{K}$ & $\mathbf{N a}$ & $\mathbf{N i}$ & $\mathbf{P}$ & $\mathbf{P b}$ & $\mathbf{S}$ & $\mathrm{Si}$ & $\mathrm{Zn}$ \\
\hline 1 & $<0.0015$ & 15.00 & 0.48 & 0.12 & 0.35 & 17.80 & 0.01 & 0.10 & 0.01 & 0.18 & 18.00 & 0.14 \\
\hline 2 & $<0.0015$ & 15.40 & 0.51 & 0.13 & 0.37 & 18.10 & 0.01 & 0.11 & 0.01 & 0.18 & 18.10 & 0.14 \\
\hline 3 & $<0.0014$ & 15.20 & 0.49 & & 0.36 & 18.00 & 0.00 & 0.10 & 0.01 & 0.17 & & 0.14 \\
\hline 4 & & 15.20 & 0.48 & & & & & & & & & 0.16 \\
\hline 5 & & 15.40 & 0.49 & & & & & & & & & 0.16 \\
\hline 6 & & 15.10 & 0.49 & & & & & & & & & 0.16 \\
\hline Average & $<0.0014$ & 15.22 & 0.49 & 0.13 & 0.36 & 17.97 & 0.01 & 0.10 & 0.01 & 0.17 & 18.05 & 0.15 \\
\hline Standard Deviation & 0.0001 & 0.16 & 0.01 & 0.01 & 0.01 & 0.15 & 0.001 & 0.003 & 0.0004 & 0.01 & 0.07 & 0.01 \\
\hline$\% \mathrm{RSD}$ & $4.49 \%$ & $1.05 \%$ & $1.87 \%$ & $4.49 \%$ & $2.39 \%$ & $0.85 \%$ & $14.32 \%$ & $3.42 \%$ & $6.04 \%$ & $3.39 \%$ & $0.39 \%$ & $6.96 \%$ \\
\hline
\end{tabular}

Table G 2. RAD A GRANULAR PRODUCT IC F-PO

\begin{tabular}{|c|c|c|c|c|c|c|}
\hline \multirow{2}{*}{ Sample } & $\mathbf{w t} \%$ & $\mathbf{w t} \%$ & $\mathbf{w t} \%$ & $\mathbf{w t} \%$ & $\mathbf{w t} \%$ & $\mathbf{w t} \%$ \\
\cline { 2 - 7 } & $\mathbf{F}$ & $\mathbf{C l}$ & $\mathbf{N O}_{2}$ & $\mathbf{N O}_{3}$ & $\mathbf{S O}_{4}$ & $\mathbf{P O}_{4}$ \\
\hline 1 & 1.14 & 1.10 & $<0.05$ & $<0.05$ & 0.31 & 0.23 \\
\hline 2 & 1.08 & 1.05 & $<0.05$ & $<0.05$ & 0.32 & 0.24 \\
\hline Average & 1.11 & 1.07 & $<0.05$ & $<0.05$ & 0.32 & 0.24 \\
\hline Standard Deviation & 0.04 & 0.03 & na & na & 0.01 & 0.01 \\
\hline \%RSD & $3.59 \%$ & $3.07 \%$ & na & na & $1.58 \%$ & $3.43 \%$ \\
\hline
\end{tabular}

Table G 3. RAD A GRANULAR PRODUCT ICPMS Cs-I

\begin{tabular}{|c|c|c|c|}
\hline \multirow{2}{*}{ Sample } & $\mathbf{w t \%}$ & $\mathbf{w t} \%$ & $\mathbf{w t} \%$ \\
\cline { 2 - 4 } & $\mathbf{C s}$ & $\mathbf{R e}$ & $\mathbf{I}$ \\
\hline 1 & 0.00033 & 0.048 & 0.00165 \\
\hline 2 & 0.00038 & 0.049 & 0.00162 \\
\hline 3 & 0.00034 & 0.047 & 0.00176 \\
\hline Average & 0.00035 & 0.048 & 0.00168 \\
\hline Standard Deviation & 0.00003 & 0.0008 & 0.00007 \\
\hline \%RSD & $7.29 \%$ & $1.70 \%$ & $4.40 \%$ \\
\hline
\end{tabular}


The radio isotopes of the RAD Granular product by gamma analysis for the Radioactive A module are shown in Table G 4.

Table G 4. RAD A GRANULAR PRODUCT GAMMA ${ }^{137} \mathrm{Cs},{ }^{99} \mathrm{Tc},{ }^{129} \mathrm{I},{ }^{125} \mathrm{I}$

\begin{tabular}{|c|c|c|c|c|}
\hline \multirow{2}{*}{ Sample } & $\mathbf{d p m} / \mathbf{g}$ & $\mathbf{d p m} / \mathbf{g}$ & $\mathbf{d p m} / \mathbf{g}$ & $\mathbf{d p m} / \mathbf{g}$ \\
\cline { 2 - 5 } & ${ }^{137} \mathrm{Cs}$ & ${ }^{125} \mathrm{I}$ & ${ }^{129} \mathrm{I}$ & ${ }^{\mathbf{9 9}} \mathrm{Tc}$ \\
\hline 1 & $4.10 \mathrm{E}+07$ & $4.44 \mathrm{E}+04$ & $4.78 \mathrm{E}+03$ & $6.86 \mathrm{E}+05$ \\
\hline 2 & $4.02 \mathrm{E}+07$ & $5.94 \mathrm{E}+04$ & $5.84 \mathrm{E}+03$ & $7.40 \mathrm{E}+05$ \\
\hline 3 & $4.20 \mathrm{E}+07$ & $5.25 \mathrm{E}+04$ & $6.27 \mathrm{E}+03$ & $8.13 \mathrm{E}+05$ \\
\hline Average & $4.11 \mathrm{E}+07$ & $5.21 \mathrm{E}+04$ & $5.63 \mathrm{E}+03$ & $7.46 \mathrm{E}+05$ \\
Standard Deviation & $9.02 \mathrm{E}+05$ & $7.47 \mathrm{E}+03$ & $7.67 \mathrm{E}+02$ & $6.37 \mathrm{E}+04$ \\
\hline \%RSD & $2.20 \%$ & $14.34 \%$ & $13.62 \%$ & $8.54 \%$ \\
\hline
\end{tabular}

The DMR condensate filtrate cation or ICPES concentrations from the two runs for RAD A module are shown in Table G 5. The DMR condensate filtrates can be represented as one volume of $0.5676 \mathrm{~L}$ with composite concentrations based on the individual run averages times the volume per run. For example, the aluminum composite concentration in $\mathrm{mg} / \mathrm{L}$ is calculated as:

$$
c f_{A l}=\frac{0.2120 * 8.53 E-01+0.3556 * N A}{0.2120+0.3556}=\frac{1.808 E-01}{0.5676}=3.19 E-01
$$

The cation or ICPES concentrations based on this method for the DMR Condensate Composite Filtrate are shown in Table G 6 and these values are used in the mass balance. 


\section{Table G 5. RAD A DMR CONDENSATE FILTRATES ICPES Ag-Zn}

\begin{tabular}{|c|c|c|c|c|c|c|c|c|c|c|c|c|c|}
\hline Run & $\mathbf{L}$ & $\mathrm{mg} / \mathrm{L}$ & $\mathrm{mg} / \mathrm{L}$ & $\mathrm{mg} / \mathrm{L}$ & $\mathrm{mg} / \mathrm{L}$ & $\mathrm{mg} / \mathrm{L}$ & $\mathrm{mg} / \mathrm{L}$ & $\mathrm{mg} / \mathrm{L}$ & $\mathrm{mg} / \mathrm{L}$ & $\mathrm{mg} / \mathrm{L}$ & $\mathrm{mg} / \mathrm{L}$ & $\mathrm{mg} / \mathrm{L}$ & $\mathrm{mg} / \mathrm{L}$ \\
\hline Kun & Volume & $\mathrm{Ag}$ & Al & B & $\mathrm{Cr}$ & K & $\mathrm{Na}$ & $\mathbf{N i}$ & $\mathbf{P}$ & $\mathbf{P b}$ & $\mathrm{S}$ & $\mathrm{Si}$ & $\mathbf{Z n}$ \\
\hline 1 & 0.2120 & $<3.70 \mathrm{E}-02$ & $8.53 \mathrm{E}-01$ & $1.20 \mathrm{E}+01$ & $7.20 \mathrm{E}-02$ & $5.06 \mathrm{E}-01$ & $5.81 \mathrm{E}+01$ & $<3.80 \mathrm{E}-02$ & $<6.74 \mathrm{E}-01$ & $<1.21 \mathrm{E}+00$ & $2.81 \mathrm{E}+00$ & $5.07 \mathrm{E}+01$ & $<1.00 \mathrm{E}-01$ \\
\hline 2 & 0.3556 & $<3.72 \mathrm{E}-01$ & $<1.88 \mathrm{E}+00$ & $1.09 \mathrm{E}+01$ & $<1.06 \mathrm{E}-01$ & $<4.00 \mathrm{E}+00$ & $9.25 \mathrm{E}+01$ & $<3.84 \mathrm{E}-01$ & $<6.74 \mathrm{E}+00$ & $<1.21 \mathrm{E}+01$ & $2.15 \mathrm{E}+01$ & $1.63 \mathrm{E}+01$ & $<1.00 \mathrm{E}-01$ \\
\hline
\end{tabular}

Table G 6. RAD A DMR CONDENSATE COMPOSITE FILTRATE ICPES Ag-Zn

\begin{tabular}{|c|c|c|c|c|c|c|c|c|c|c|c|c|c|}
\hline Run & $\mathbf{L}$ & $\mathrm{mg} / \mathrm{L}$ & $\mathrm{mg} / \mathrm{L}$ & $\mathrm{mg} / \mathrm{L}$ & $\mathrm{mg} / \mathrm{L}$ & $\mathrm{mg} / \mathrm{L}$ & $\mathrm{mg} / \mathrm{L}$ & $\mathrm{mg} / \mathrm{L}$ & $\mathrm{mg} / \mathrm{L}$ & $\mathrm{mg} / \mathrm{L}$ & $\mathrm{mg} / \mathrm{L}$ & $\mathrm{mg} / \mathrm{L}$ & $\mathrm{mg} / \mathrm{L}$ \\
\hline Run & Volume & Ag & Al & B & $\mathrm{Cr}$ & K & $\mathbf{N a}$ & $\mathrm{Ni}$ & $\mathbf{P}$ & $\mathbf{P b}$ & S & Si & $\mathbf{Z n}$ \\
\hline Composite & 0.5676 & $<2.47 \mathrm{E}-01$ & $3.19 \mathrm{E}-01$ & $1.13 \mathrm{E}+01$ & $2.69 \mathrm{E}-02$ & $1.89 \mathrm{E}-01$ & $7.97 \mathrm{E}+01$ & $<2.55 \mathrm{E}-01$ & $<4.47 \mathrm{E}+00$ & $<8.03 \mathrm{E}+00$ & $1.45 \mathrm{E}+01$ & $2.91 \mathrm{E}+01$ & $7.10 \mathrm{E}-03$ \\
\hline
\end{tabular}


Anion or IC analyses were not performed on the RAD A DMR condensate filtrate but the SO4 concentration can be estimated from the $\mathrm{S}$ analysis as shown earlier for crossbar rinse filtered solids for SIM A. Using this same logic, the estimated SO4 concentration for the seal pot leg condensate drains filtered solids are shown in Table G 7.

Table G 7. RAD A DMR CONDENSATE FILTRATE COMPOSITE FILTRATE ESTIMATED $\mathrm{SO}_{4}$

\begin{tabular}{|c|c|c|}
\hline \multirow{2}{*}{ Run } & $\mathbf{L}$ & $\mathbf{u g} / \mathbf{L}$ \\
\cline { 2 - 3 } & Volume & $\mathbf{S O}_{4}$ \\
\hline Composite & 0.5676 & $4.35 \mathrm{E}+04$ \\
\hline
\end{tabular}

The DMR condensate filtrate trace elemental or ICPMS concentrations from the two runs for Simulant A module are shown in Table G 8. The DMR condensate filtrates can be represented as one volume of 0.749 $\mathrm{L}$ with composite concentrations based on the individual run averages times the volume per run. For example, the cesium composite concentration in $\mathrm{ug} / \mathrm{L}$ is calculated as:

$$
c f_{C s}=\frac{0.2120 * 2.83 E 00+0.3556 * 3.50 E 00}{0.2120+0.3556}=\frac{1.85 E 00}{0.5676}=3.25 E 00
$$

The trace elemental or ICPMS concentrations based on this method for the DMR Condensate Composite Filtrate are shown in Table G 9 and these values are used in the mass balance.

Table G 8. RAD A DMR CONDENSATE FILTRATES ICPMS Cs, Re, I

\begin{tabular}{|c|c|c|c|c|}
\hline \multirow{2}{*}{ Run } & $\mathbf{L}$ & $\mathbf{u g} / \mathbf{L}$ & $\mathbf{u g} / \mathbf{L}$ & $\mathbf{u g} / \mathbf{L}$ \\
\cline { 2 - 5 } & Volume & $\mathbf{C s}$ & $\mathbf{R e}$ & $\mathbf{I}$ \\
\hline 1 & 0.2120 & $2.83 \mathrm{E}+00$ & $3.88 \mathrm{E}+02$ & $1.08 \mathrm{E}+02$ \\
\hline 2 & 0.3556 & $3.50 \mathrm{E}+00$ & $5.96 \mathrm{E}+02$ & $2.77 \mathrm{E}+02$ \\
\hline
\end{tabular}

Table G 9. RAD A DMR CONDENSATE COMPOSITE FILTRATE ICPMS Cs, Re, I

\begin{tabular}{|c|c|c|c|c|}
\hline \multirow{2}{*}{ Run } & $\mathbf{L}$ & $\mathbf{u g} / \mathbf{L}$ & $\mathbf{u g} / \mathbf{L}$ & $\mathbf{u g} / \mathbf{L}$ \\
\cline { 2 - 5 } & Volume & $\mathbf{C s}$ & $\mathbf{R e}$ & $\mathbf{I}$ \\
\hline Composite & 0.749 & $3.25 \mathrm{E}+00$ & $5.18 \mathrm{E}+02$ & $2.14+02$ \\
\hline
\end{tabular}

The radio isotopes of the DMR Condensate filtrate by gamma analysis for the Radioactive A module are shown in Table G 10. Using the same logic shown earlier, the DMR Condensate data can be represented as one volume of $192.437 \mathrm{~mL}$ with composite concentrations.

These composite concentrations are shown in Table G 11 and are used in the mass balance.

Table G 10. RAD A DMR CONDENSATE FILTRATE GAMMA ${ }^{137} \mathrm{Cs},{ }^{99} \mathrm{Tc},{ }^{129} \mathrm{I},{ }^{125} \mathrm{I}$

\begin{tabular}{|c|c|c|c|c|c|}
\hline \multirow{2}{*}{ Run } & $\mathbf{m L}$ & $\mathbf{d p m} / \mathbf{m L}$ & $\mathbf{d p m} / \mathbf{m L}$ & $\mathbf{d p m} / \mathbf{m L}$ & $\mathbf{d p m} / \mathbf{m L}$ \\
\cline { 2 - 6 } & $\mathbf{V o l u m e}$ & ${ }^{\mathbf{1 3 7}} \mathbf{C s}$ & ${ }^{\mathbf{1 2 5}} \mathrm{I}$ & ${ }^{\mathbf{1 2 9}} \mathrm{I}$ & ${ }^{\mathbf{9 9}} \mathrm{Tc}$ \\
\hline 1 & 211.977 & $3.23 \mathrm{E}+04$ & $1.55 \mathrm{E}+02$ & $1.75 \mathrm{E}+01$ & $2.91 \mathrm{E}+02$ \\
\hline 2 & 355.573 & $7.36 \mathrm{E}+04$ & $2.16 \mathrm{E}+02$ & $2.53 \mathrm{E}+01$ & $2.76 \mathrm{E}+02$ \\
\hline
\end{tabular}


Table G 11. RAD A DMR CONDENSATE COMPOSITE FILTRATE GAMMA ${ }^{137} \mathrm{Cs},{ }^{99} \mathrm{Tc},{ }^{129} \mathrm{I},{ }^{125} \mathrm{I}$

\begin{tabular}{|c|c|c|c|c|c|}
\hline \multirow{2}{*}{ Run } & $\mathbf{m L}$ & $\mathbf{d p m} / \mathbf{m L}$ & $\mathbf{d p m} / \mathbf{m L}$ & $\mathbf{d p m} / \mathbf{m L}$ & $\mathbf{d p m} / \mathbf{m L}$ \\
\cline { 2 - 6 } & Volume & ${ }^{\mathbf{1 3 7}} \mathrm{Cs}$ & ${ }^{\mathbf{1 2 5}} \mathrm{I}$ & ${ }^{\mathbf{1 2 9}} \mathrm{I}$ & ${ }^{\mathbf{9 9}} \mathrm{Tc}$ \\
\hline Composite & 567.550 & $5.82 \mathrm{E}+04$ & $1.94 \mathrm{E}+02$ & $2.24 \mathrm{E}+01$ & $2.82 \mathrm{E}+02$ \\
\hline
\end{tabular}

The DMR condensate filtered solids concentrations from the runs for RAD A module are shown in Table G 12. The DMR condensate filtered solids can be represented as one mass of $0.01532 \mathrm{~g}$ with composite concentrations based on the individual run values times the mass per run. For example, the aluminum composite concentration in $\mathrm{wt} \%$ is calculated as:

$$
C S_{A l}=\frac{0.00218 * 42.45 \%+0.00908 * 57.72 \%}{0.00218+0.00908}=\frac{0.006166}{0.01126}=54.76 \%
$$

The cation or ICPES concentrations based on this method for the DMR Condensate Composite filtered solids are shown in Table G 13 and these values are used in the mass balance. 


\section{Table G 12. RAD A DMR CONDENSATE FILTERED SOLIDS ICPES Ag-Zn}

\begin{tabular}{|c|c|c|c|c|c|c|c|c|c|c|c|c|c|}
\hline \multirow{2}{*}{ Run } & g & wt $\%$ & wt\% & wt $\%$ & wt $\%$ & wt $\%$ & wt $\%$ & wt $\%$ & wt $\%$ & wt $\%$ & wt $\%$ & wt $\%$ & wt $\%$ \\
\hline & Mass & Ag & Al & B & $\mathrm{Cr}$ & $\mathbf{K}$ & $\mathbf{N a}$ & $\mathbf{N i}$ & $\mathbf{P}$ & $\mathbf{P b}$ & $\mathbf{S}$ & Si & $\mathbf{Z n}$ \\
\hline 1 & 0.00218 & $<0.85$ & 42.45 & 2.20 & 0.64 & $<9.17$ & 13.62 & $<4.26$ & $<3.89$ & $<3.35$ & $<34.38$ & 16.55 & 0.50 \\
\hline 2 & 0.00908 & $<0.20$ & 57.72 & 0.88 & 0.31 & $<2.20$ & 18.73 & $<1.02$ & $<0.94$ & $<0.81$ & $<8.26$ & 13.99 & 0.38 \\
\hline
\end{tabular}

Table G 13. RAD A DMR CONDENSATE COMPOSITE FILTERED SOLIDS ICPES Ag-Zn

\begin{tabular}{|c|c|c|c|c|c|c|c|c|c|c|c|c|c|}
\hline \multirow{2}{*}{ Run } & g & $w t \%$ & wt $\%$ & wt $\%$ & wt $\%$ & $w t \%$ & $w t \%$ & wt $\%$ & wt $\%$ & $w t \%$ & wt \% & $w t \%$ & wt $\%$ \\
\hline & Mass & Ag & Al & B & $\mathrm{Cr}$ & $\mathbf{K}$ & $\mathrm{Na}$ & $\mathbf{N i}$ & $\mathbf{P}$ & $\mathbf{P b}$ & $\mathbf{S}$ & Si & $\mathrm{Zn}$ \\
\hline Composite & 0.0113 & $<0.33$ & 54.76 & 1.13 & 0.37 & $<3.55$ & 17.74 & $<1.65$ & $<1.51$ & $<1.30$ & $<13.32$ & 14.49 & 0.40 \\
\hline
\end{tabular}


Anion or IC analyses were not performed on the RAD A DMR Condensate Filtered Solids samples and the $\mathrm{S}$ and $\mathrm{P}$ analyses were less than detectable so the SO4 and PO4 concentrations were not estimated.

The DMR condensate filtered solids trace elemental or ICPMS concentrations from the two runs for Radioactive A module are shown in Table G 14. Using the same logic shown earlier, the two runs of DMR condensate filtered solids data can be represented as one mass of $0.0113 \mathrm{~g}$ with composite concentrations. These composite concentrations are shown in Table G 15 and are used in the mass balance.

Table G 14. RAD A DMR CONDENSATE FILTERED SOLIDS ICPMS Cs, Re, I

\begin{tabular}{|c|c|c|c|c|}
\hline \multirow{2}{*}{ Run } & $\mathbf{g}$ & $\mathbf{w t} \%$ & $\mathbf{w t \%}$ & $\mathbf{w t} \%$ \\
\cline { 2 - 5 } & Mass & Cs & $\mathbf{R e}$ & $\mathbf{I}$ \\
\hline 1 & 0.00218 & NA & 0.040 & 0.01 \\
\hline 2 & 0.00908 & NA & 0.026 & 0.003 \\
\hline
\end{tabular}

$\mathrm{NA}=$ Not Available

Table G 15. RAD A DMR CONDENSATE COMPOSITE FILTERED SOLIDS ICPMS Cs, Re, I

\begin{tabular}{|c|c|c|c|c|}
\hline \multirow{2}{*}{ Run } & $\mathbf{g}$ & $\mathbf{w t} \%$ & $\mathbf{w t} \%$ & $\mathbf{w t} \%$ \\
\cline { 2 - 5 } & Mass & $\mathbf{C s}$ & $\mathbf{R e}$ & $\mathbf{I}$ \\
\hline Composite & 0.0113 & NA & 0.029 & 0.003 \\
\hline
\end{tabular}

$\mathrm{NA}=$ Not Available

The radio isotopes of the DMR condensate filtered solids by gamma analysis for the Radioactive A module are shown in Table G 16. Using the same logic shown earlier, the crossbar rinse filtered solids data can be represented as one mass of $0.006148 \mathrm{~g}$ with composite concentrations. For example, the DMR condensate filtered solids concentration of ${ }^{137} \mathrm{Cs}$ is found by:

$$
x S_{C s-137}=\frac{0.001331 * 4.76 E+07+0.004817 * 7.76 E+07}{0.001331+0.004817}=\frac{4.372 E+05}{0.006148}=7.11 E+07
$$

These composite concentrations are shown in Table G 17 and are used in the mass balance.

Table G 16. RAD A DMR CONDENSATE FILTERED SOLIDS GAMMA ${ }^{137} \mathrm{Cs},{ }^{99} \mathrm{Tc},{ }^{129} \mathrm{I},{ }^{125} \mathrm{I}$

\begin{tabular}{|c|c|c|c|c|c|}
\hline \multirow{2}{*}{ Run } & $\mathbf{g}$ & $\mathbf{d p m} / \mathbf{g}$ & $\mathbf{d p m} / \mathbf{g}$ & $\mathbf{d p m} / \mathbf{g}$ & $\mathbf{d p m} / \mathbf{g}$ \\
\cline { 2 - 6 } & $\mathbf{M a s s}$ & ${ }^{1 \mathbf{1 3 7}} \mathrm{Cs}$ & ${ }^{\mathbf{1 2 5}} \mathrm{I}$ & ${ }^{129} \mathrm{I}$ & ${ }^{\mathbf{1}} \mathrm{Tc}$ \\
\hline 1 & 0.002181 & $6.97 \mathrm{E}+07$ & $4.11 \mathrm{E}+05$ & $4.19 \mathrm{E}+04$ & $5.27 \mathrm{E}+05$ \\
\hline 2 & 0.009078 & $5.68 \mathrm{E}+07$ & $4.14 \mathrm{E}+04$ & $<4.80 \mathrm{E}+03$ & $7.55 \mathrm{E}+05$ \\
\hline
\end{tabular}

Table G 17. RAD A DMR CONDENSATE COMPOSITE FILTERED SOLIDS GAMMA ${ }^{137}$ Cs, ${ }^{99} \mathrm{Tc},{ }^{129} \mathrm{I},{ }^{125} \mathrm{I}$

\begin{tabular}{|c|c|c|c|c|c|}
\hline \multirow{2}{*}{ Run } & $\mathbf{g}$ & $\mathbf{d p m} / \mathbf{g}$ & $\mathbf{d p m} / \mathbf{g}$ & $\mathbf{d p m} / \mathbf{g}$ & $\mathbf{d p m} / \mathbf{g}$ \\
\cline { 2 - 6 } & Mass & ${ }^{137} \mathrm{Cs}$ & ${ }^{125} \mathrm{I}$ & ${ }^{129} \mathrm{I}$ & ${ }^{99} \mathrm{Tc}$ \\
\hline Composite & 0.011259 & $5.93 \mathrm{E}+07$ & $1.13 \mathrm{E}+05$ & $8.13 \mathrm{E}+03$ & $7.10 \mathrm{E}+05$ \\
\hline
\end{tabular}

The crossbar rinse filtrate cation or ICPES concentrations from the runs for Radioactive A module are shown in Table G 18. The crossbar rinse filtrates can be represented as one volume of $0.1408 \mathrm{~L}$ with 
composite concentrations based on the individual run averages times the volume per run. For example, the aluminum composite concentration in $\mathrm{mg} / \mathrm{L}$ is calculated as:

$$
x f_{A l}=\frac{0.0705 * 9.34 E 01+0.0703 * 4.65 E 01}{0.0705+0.0703}=\frac{9.85 E 00}{0.1408}=7.00 E 01
$$

The cation or ICPES concentrations based on this method for the crossbar rinse Composite Filtrate are shown in Table G 19 and these values are used in the mass balance. 
Table G 18. RAD A CROSSBAR RINSE FILTRATES ICPES Ag-Zn

\begin{tabular}{|c|c|c|c|c|c|c|c|c|c|c|c|c|c|c|}
\hline \multirow{2}{*}{ Run } & $\mathbf{L}$ & \multirow{2}{*}{ Sample } & $\mathrm{mg} / \mathrm{L}$ & $\mathrm{mg} / \mathrm{L}$ & $\mathrm{mg} / \mathrm{L}$ & $\mathrm{mg} / \mathrm{L}$ & $\mathrm{mg} / \mathrm{L}$ & $\mathrm{mg} / \mathrm{L}$ & $\mathrm{mg} / \mathrm{L}$ & $\mathrm{mg} / \mathrm{L}$ & $\mathrm{mg} / \mathrm{L}$ & $\mathrm{mg} / \mathrm{L}$ & $\mathrm{mg} / \mathrm{L}$ & $\mathrm{mg} / \mathrm{L}$ \\
\hline & Volume & & $\mathrm{Ag}$ & Al & B & $\mathrm{Cr}$ & K & $\mathrm{Na}$ & $\mathbf{N i}$ & $\mathbf{P}$ & $\mathbf{P b}$ & $\mathrm{S}$ & $\mathbf{S i}$ & $\mathbf{Z n}$ \\
\hline 1 & 0.0884 & 1 & $<3.70 \mathrm{E}-02$ & $1.10 \mathrm{E}+00$ & $6.37 \mathrm{E}+00$ & $2.10 \mathrm{E}-02$ & $<4.00 \mathrm{E}-01$ & $4.55 \mathrm{E}+01$ & $<3.80 \mathrm{E}-02$ & $<6.74 \mathrm{E}-01$ & $<1.21 \mathrm{E}+00$ & $2.24 \mathrm{E}+00$ & $1.17 \mathrm{E}+01$ & $5.60 \mathrm{E}-03$ \\
\hline 2 & 0.1040 & 1 & $<3.70 \mathrm{E}-02$ & $1.47 \mathrm{E}+01$ & $1.76 \mathrm{E}+01$ & $4.06 \mathrm{E}-02$ & $<4.00 \mathrm{E}-01$ & $3.91 \mathrm{E}+01$ & $<3.80 \mathrm{E}-02$ & $<6.74 \mathrm{E}-01$ & $<1.21 \mathrm{E}+00$ & $3.25 \mathrm{E}+00$ & $5.01 \mathrm{E}+01$ & $3.14 \mathrm{E}-02$ \\
\hline
\end{tabular}

Table G 19. RAD A CROSSBAR RINSE COMPOSITE FILTRATE ICPES Ag-Zn

\begin{tabular}{|c|c|c|c|c|c|c|c|c|c|c|c|c|c|}
\hline \multirow{2}{*}{ Run } & $\mathbf{L}$ & $\mathrm{mg} / \mathrm{L}$ & $\mathrm{mg} / \mathrm{L}$ & $\mathrm{mg} / \mathrm{L}$ & $\mathrm{mg} / \mathrm{L}$ & $\mathrm{mg} / \mathrm{L}$ & $\mathrm{mg} / \mathrm{L}$ & $\mathrm{mg} / \mathrm{L}$ & $\mathrm{mg} / \mathrm{L}$ & $\mathrm{mg} / \mathrm{L}$ & $\mathrm{mg} / \mathrm{L}$ & $\mathrm{mg} / \mathrm{L}$ & $\mathrm{mg} / \mathrm{L}$ \\
\hline & Volume & Ag & Al & B & $\mathrm{Cr}$ & $\mathbf{K}$ & $\mathbf{N a}$ & $\mathrm{Ni}$ & $\mathbf{P}$ & $\mathbf{P b}$ & $\mathbf{S}$ & Si & $\mathbf{Z n}$ \\
\hline Composite & 0.1924 & $<3.70 \mathrm{E}-02$ & $8.45 \mathrm{E}+00$ & $1.24 \mathrm{E}+01$ & $3.16 \mathrm{E}-02$ & $4.00 \mathrm{E}-01$ & $4.20 \mathrm{E}+01$ & $<3.80 \mathrm{E}-02$ & $<6.74 \mathrm{E}-01$ & $<1.21 \mathrm{E}+00$ & $2.79 \mathrm{E}+00$ & $3.25 \mathrm{E}+01$ & $2.57 \mathrm{E}-03$ \\
\hline
\end{tabular}


Anion or IC analyses were not performed on the RAD A crossbar rinse filtrate but the $\mathrm{SO}_{4}$ concentration can be estimated from the $\mathrm{S}$ analysis as shown earlier for crossbar rinse filtered solids for SIM A. Using this same logic, the estimated $\mathrm{SO}_{4}$ concentration for the crossbar rinse filtrate is shown in Table $\mathrm{G} 20$.

Table G 20. RAD A CROSSBAR RINSE COMPOSITE FILTRATE ESTIMATED SO 4

\begin{tabular}{|c|c|c|}
\hline \multirow{2}{*}{ Run } & $\mathbf{L}$ & $\mathbf{u g} / \mathbf{L}$ \\
\cline { 2 - 3 } & Volume & $\mathbf{S O}_{4}$ \\
\hline Composite & 0.1924 & $8.35 \mathrm{E}+03$ \\
\hline
\end{tabular}

The crossbar rinse filtrate trace elemental or ICPMS concentrations from the two runs for Simulant A module are shown in Table G 21. The DMR condensate filtrates can be represented as one volume of $0.1408 \mathrm{~L}$ with composite concentrations based on the individual run averages times the volume per run. For example, the cesium composite concentration in $\mathrm{ug} / \mathrm{L}$ is calculated as:

$$
x f_{C s}=\frac{0.0884 * 5.92 E-01+0.104 * 8.51 E-01}{0.0884+0.1040}=\frac{1.408 E-01}{0.1924}=7.32 E-01
$$

The trace elemental or ICPMS concentrations based on this method for the crossbar rinse filtrate are shown in Table G 22 and these values are used in the mass balance.

Table G 21. RAD A CROSSBAR RINSE FILTRATES ICPMS Cs, Re, I

\begin{tabular}{|c|c|c|c|c|}
\hline \multirow{2}{*}{ Run } & $\mathbf{L}$ & $\mathbf{u g} / \mathbf{L}$ & $\mathbf{u g} / \mathbf{L}$ & $\mathbf{u g} / \mathbf{L}$ \\
\cline { 2 - 5 } & Volume & $\mathbf{C s}$ & $\mathbf{R e}$ & $\mathbf{I}$ \\
\hline 1 & 0.0884 & $5.92 \mathrm{E}-01$ & $1.02 \mathrm{E}+02$ & $4.25 \mathrm{E}+01$ \\
\hline 2 & 0.1040 & $8.51 \mathrm{E}-01$ & $1.44 \mathrm{E}+02$ & $3.62 \mathrm{E}+01$ \\
\hline
\end{tabular}

Table G 22. RAD A CROSSBAR RINSE COMPOSITE FILTRATE ICPMS Cs, Re, I

\begin{tabular}{|c|c|c|c|c|}
\hline \multirow{2}{*}{ Run } & $\mathbf{L}$ & $\mathbf{u g} / \mathbf{L}$ & $\mathbf{u g} / \mathbf{L}$ & $\mathbf{u g} / \mathbf{L}$ \\
\cline { 2 - 5 } & Volume & Cs & $\mathbf{R e}$ & $\mathbf{I}$ \\
\hline Composite & 0.1924 & $7.32 \mathrm{E}-01$ & $1.25 \mathrm{E}+02$ & $3.91 \mathrm{E}+01$ \\
\hline
\end{tabular}

The radio isotopes of the crossbar rinse filtrate by gamma analysis for the Radioactive A module are shown in Table G 23. Using the same logic shown earlier, the crossbar rinse filtered solids data can be represented as one volume of $0.1924 \mathrm{~L}$ with composite concentrations. These composite concentrations are shown in Table G 24 and are used in the mass balance. 
Table G 23. RAD A CROSSBAR RINSE FILTRATE GAMMA ${ }^{137} \mathrm{Cs},{ }^{99} \mathrm{Tc},{ }^{129} \mathrm{I},{ }^{125} \mathrm{I}$

\begin{tabular}{|c|c|c|c|c|c|}
\hline \multirow{2}{*}{ Run } & $\mathbf{m L}$ & $\mathbf{d p m} / \mathbf{m L}$ & $\mathbf{d p m} / \mathbf{m L}$ & $\mathbf{d p m} / \mathbf{m L}$ & $\mathbf{d p m} / \mathbf{m L}$ \\
\cline { 2 - 6 } & Volume & ${ }^{\mathbf{1 3 7}} \mathrm{Cs}$ & ${ }^{\mathbf{1 2 5}} \mathrm{I}$ & ${ }^{\mathbf{1 2 9}} \mathrm{I}$ & ${ }^{\mathbf{9 9}} \mathrm{Tc}$ \\
\hline 1 & 88.435 & $9.90 \mathrm{E}+03$ & $2.43 \mathrm{E}+01$ & $2.14 \mathrm{E}+00$ & $1.00 \mathrm{E}+02$ \\
\hline 2 & 104.002 & $2.06 \mathrm{E}+04$ & $4.03 \mathrm{E}+01$ & $4.18 \mathrm{E}+00$ & $7.88 \mathrm{E}+01$ \\
\hline
\end{tabular}

Table G 24. RAD A CROSSBAR RINSE COMPOSITE FILTRATE GAMMA ${ }^{137} \mathrm{Cs},{ }^{99} \mathrm{Tc},{ }^{129} \mathrm{I},{ }^{125} \mathrm{I}$

\begin{tabular}{|c|c|c|c|c|c|}
\hline \multirow{2}{*}{ Run } & $\mathbf{m L}$ & $\mathbf{d p m} / \mathbf{m L}$ & $\mathbf{d p m} / \mathbf{m L}$ & $\mathbf{d p m} / \mathbf{m L}$ & $\mathbf{d p m} / \mathbf{m L}$ \\
\cline { 2 - 6 } & Volume & ${ }^{\mathbf{1 3 7}} \mathrm{Cs}$ & ${ }^{\mathbf{1 2 5}} \mathrm{I}$ & ${ }^{\mathbf{1 2 9}} \mathrm{I}$ & ${ }^{\mathbf{9 9}} \mathrm{Tc}$ \\
\hline Composite & 192.437 & $1.57 \mathrm{E}+04$ & $3.30 \mathrm{E}+01$ & $3.24 \mathrm{E}+00$ & $8.85 \mathrm{E}+01$ \\
\hline
\end{tabular}

The crossbar rinse filtered solids concentrations from the runs for Radioactive A module are shown in Table G 25. The crossbar rinse filtered solids can be represented as one mass of $0.00578 \mathrm{~g}$ with composite concentrations based on the individual run values times the mass per run. For example, the aluminum composite concentration in $\mathrm{wt} \%$ is calculated as:

$$
x S_{A l}=\frac{0.001331 * 20.73 \%+0.004817 * 47.96 \%}{0.001331+0.004817}=\frac{2.586 E-03}{0.006148}=42.06 \%
$$

The cation or ICPES concentrations based on this method for the DMR Condensate Composite filtered solids are shown in Table G 26 and these values are used in the mass balance. 
Table G 25. RAD A CROSSBAR RINSE FILTERED SOLIDS ICPES Ag-Zn

\begin{tabular}{|c|c|c|c|c|c|c|c|c|c|c|c|c|c|}
\hline Pun & g & wt $\%$ & wt $\%$ & wt $\%$ & wt\% $\%$ & wt $\%$ & wt $\%$ & wt\% & wt $\%$ & wt $\%$ & wt\% & wt $\%$ & wt $\%$ \\
\hline Run & Mass & Ag & Al & B & $\mathrm{Cr}$ & $\mathbf{K}$ & $\mathbf{N a}$ & $\mathbf{N i}$ & $\mathbf{P}$ & $\mathbf{P b}$ & $\mathbf{S}$ & Si & Zn \\
\hline 1 & 0.001331 & $<1.40$ & 20.73 & 1.42 & $<1.04$ & $<15.02$ & 23.36 & $<6.99$ & $<6.38$ & $<5.49$ & $<56.34$ & 17.05 & 0.53 \\
\hline 2 & 0.004817 & $<0.39$ & 47.96 & 0.94 & $<0.43$ & $<4.15$ & 26.16 & $<1.93$ & $<1.76$ & $<1.52$ & $<15.57$ & 9.99 & 0.49 \\
\hline
\end{tabular}

Table G 26. SIM A CROSSBAR RINSE COMPOSITE FILTERED SOLIDS ICPES Ag-Zn

\begin{tabular}{|c|c|c|c|c|c|c|c|c|c|c|c|c|c|}
\hline \multirow{2}{*}{ Run } & g & wt\% & wt $\%$ & $w t \%$ & wt\% & wt $\%$ & wt $\%$ & wt $\%$ & wt $\%$ & wt $\%$ & wt $\%$ & wt $\%$ & $w t \%$ \\
\hline & Mass & Ag & Al & B & $\mathrm{Cr}$ & $\mathbf{K}$ & $\mathbf{N a}$ & $\mathbf{N i}$ & $\mathbf{P}$ & $\mathbf{P b}$ & $\mathbf{S}$ & Si & $\mathbf{Z n}$ \\
\hline Composite & 0.006148 & $<0.61$ & 42.06 & 1.05 & 0.33 & $<6.51$ & 25.55 & $<3.03$ & $<2.76$ & $<2.38$ & $<24.40$ & 11.52 & 0.50 \\
\hline
\end{tabular}


Anion or IC analyses were not performed on the RAD A Crossbar Rinse Filtered Solids samples and the $\mathrm{S}$ and $\mathrm{P}$ analyses were less than detectable so the $\mathrm{SO} 4$ and $\mathrm{PO} 4$ concentrations were not estimated.

The crossbar rinse filtered solids trace elemental or ICPMS concentrations from the runs for Radioactive A module are shown in Table G 27. Using the same logic shown earlier, the crossbar rinse filtered solids data can be represented as one mass of $0.006148 \mathrm{~g}$ with composite concentrations. These composite concentrations are shown in Table G 28 and are used in the mass balance.

Table G 27. RAD A CROSSBAR RINSE FILTERED SOLIDS ICPMS Re, I

\begin{tabular}{|c|c|c|c|}
\hline \multirow{2}{*}{ Run } & $\mathbf{g}$ & $\mathbf{w t} \%$ & $\mathbf{w t} \%$ \\
\cline { 2 - 4 } & Mass & $\mathbf{R e}$ & $\mathbf{I}$ \\
\hline 1 & 0.001331 & 0.024 & $<0.023$ \\
\hline 2 & 0.004817 & 0.024 & $<0.006$ \\
\hline
\end{tabular}

Table G 28. RAD A CROSSBAR RINSE COMPOSITE FILTERED SOLIDS ICPMS Re, I

\begin{tabular}{|c|c|c|c|}
\hline \multirow{2}{*}{ Run } & g & wt\% & wt\% \\
\cline { 2 - 4 } & Mass & Re & I \\
\hline Composite & 0.006148 & 0.024 & $<0.01$ \\
\hline
\end{tabular}

The radio isotopes of the crossbar rinse filtered solids by gamma analysis for the Radioactive A module are shown in Table G 29. Using the same logic shown earlier, the crossbar rinse filtered solids data can be represented as one mass of $0.006148 \mathrm{~g}$ with composite concentrations. For example, the crossbar rinse filtered solids concentration of ${ }^{137} \mathrm{Cs}$ is found by:

$$
x s_{C s-137}=\frac{(0.001331 * 4.76 E+07)+(0.004817 * 7.76 E+07)}{0.001331+0.004817}=\frac{4.372 E+05}{0.006148}=7.11 E+07
$$

These composite concentrations are shown in Table G30 and are used in the mass balance.

Table G 29. RAD A CROSSBAR RINSE FILTERED SOLIDS GAMMA ${ }^{137} \mathrm{Cs},{ }^{99} \mathrm{Tc},{ }^{129} \mathrm{I},{ }^{125} \mathrm{I}$

\begin{tabular}{|c|c|c|c|c|c|}
\hline \multirow{2}{*}{ Run } & $\mathbf{g}$ & $\mathbf{d p m} / \mathbf{g}$ & $\mathbf{d p m} / \mathbf{g}$ & $\mathbf{d p m} / \mathbf{g}$ & $\mathbf{d p m} / \mathbf{g}$ \\
\cline { 2 - 6 } & $\mathbf{M a s s}$ & ${ }^{\mathbf{1 3 7}} \mathrm{Cs}$ & ${ }^{\mathbf{1 2 5}} \mathrm{I}$ & ${ }^{\mathbf{1 2 9}} \mathrm{I}$ & $<$ \\
\hline 1 & 0.001331 & $4.76 \mathrm{E}+07$ & $9.93 \mathrm{E}+04$ & $<5.53 \mathrm{E}+04$ & $<4.96 \mathrm{E}+05$ \\
\hline 2 & 0.004817 & $7.76 \mathrm{E}+07$ & $7.80 \mathrm{E}+04$ & $7.79 \mathrm{E}+03$ & $1.41 \mathrm{E}+06$ \\
\hline
\end{tabular}
Table G 30. RAD A CROSSBAR RINSE COMPOSITE FILTERED SOLIDS GAMMA ${ }^{129} \mathrm{I}$, Cs, ${ }^{125} \mathrm{I}$ Te,

\begin{tabular}{|c|c|c|c|c|c|}
\hline \multirow{2}{*}{ Run } & $\mathbf{g}$ & $\mathbf{d p m} / \mathbf{g}$ & $\mathbf{d p m} / \mathbf{g}$ & $\mathbf{d p m} / \mathbf{g}$ & $\mathbf{d p m} / \mathbf{g}$ \\
\cline { 2 - 6 } & Mass & ${ }^{\mathbf{1 3 7}} \mathrm{Cs}$ & ${ }^{\mathbf{1 2 5}} \mathrm{I}$ & ${ }^{\mathbf{1 2 9}} \mathrm{I}$ & ${ }^{\mathbf{9 9}} \mathrm{Tc}$ \\
\hline Composite & 0.006148 & $7.11 \mathrm{E}+07$ & $8.26 \mathrm{E}+04$ & $6.10 \mathrm{E}+03$ & $1.10 \mathrm{E}+06$ \\
\hline
\end{tabular}




\section{Distribution:}
A. B. Barnes, 999-W
D. A. Crowley, 773-43A
A. P. Fellinger, 773-42A
S. D. Fink, 773-A
B. J. Giddings, 786-5A
C. C. Herman, 999-W
S. L. Marra, 773-A
F. M. Pennebaker, 773-42A
W. R. Wilmarth, 773-A 